AUTARQUIA ASSOCIADA À UNIVERSIDADE DE SÃO PAULO

\title{
AVALIAÇÃO TRIBOLÓGICA DO PAR VÁLVULA E SEDE DE VÁLVULA DE ADMISSÃO DE UM MOTOR CICLO DIESEL EM CONDIÇÕES REAIS DE FUNCIONAMENTO
}

\author{
LUCIANO TADEU BAFFI PENHALBEL
}

Dissertação apresentada como parte dos requisitos para obtenção do Grau de Mestre em Ciências na Área de Tecnologia Nuclear - Materiais

Orientadora:

Profa. Dra. Marina Fuser Pillis 


\title{
INSTITUTO DE PESQUISAS ENERGÉTICAS E NUCLEARES \\ Autarquia associada à Universidade de São Paulo
}

\section{AVALIAÇÃO TRIBOLÓGICA DO PAR VÁLVULA E SEDE DE VÁLVULA DE ADMISSÃO DE UM MOTOR CICLO DIESEL EM CONDIÇÕES REAIS DE FUNCIONAMENTO}

\author{
LUCIANO TADEU BAFFI PENHALBEL
}

Dissertação apresentada como parte dos
requisitos para obtenção do Grau de
$\begin{aligned} & \text { Mestre em Ciências na Área } \\ & \text { de Tecnologia Nuclear-Materiais }\end{aligned}$
Orientadora:
Profa. Dra. Marina Fuser Pillis

Versão Corrigida

Versão Original disponível no IPEN

São Paulo 
Autorizo a reprodução e divulgação total ou parcial deste trabalho, para fins de estudo e pesquisa, desde que citada a fonte

Como citar:

PENHALBEL, L. T. B. . Avaliação tribológica do par válvula e sede de válvula de admissão de um motor ciclo diesel em condições reais de funcionamento.

2017. 110 p. Dissertação (Mestrado em Tecnologia Nuclear), Instituto de Pesquisas Energéticas e Nucleares, IPEN-CNEN/SP, São Paulo. Disponível em: (data de consulta no formato: $\mathrm{dd} / \mathrm{mm} / \mathrm{aaaa}$ )

Ficha catalográfica elaborada pelo Sistema de geração automática da Biblioteca IPEN/USP, com os dados fornecidos pelo (a) autor (a)

PENHALBEL, LUCIANO TADEU BAFFI
Avaliação tribológica do par válvula e sede
de válvula de admissão de um motor ciclo diesel
em condições reais de funcionamento / LUCIANo
TADEU BAFFI PENHALBEL; orientadora Marina Fuser
Pillis. -- São Paulo, 2017.
124 p.
Dissertação (Mestrado) - Programa de Pós-
Graduação em Tecnologia Nuclear (Materiais) --
Instituto de Pesquisas Energéticas e Nucleares,
São Paulo, 2017.
1. Desgaste. 2. Válvula. 3. Sede de Válvula.
4. Tribologia. I. Pillis, Marina Fuser, orient.
II. Título.




\title{
FOLHA DE APROVAÇÃO
}

Autor: Luciano Tadeu Baffi Penhalbel

Título: Avaliação tribológica do par válvula e sede de válvula de admissão de um motor ciclo diesel em condições reais de funcionamento.

\author{
Dissertação (Mestrado) - Programa de Pós-Graduação em \\ Tecnologia Nuclear (Materiais) -- Instituto de Pesquisas \\ Energéticas e Nucleares.
}

Data: $01 / 11 / 2017$

\section{Banca Examinadora}

Prof. Dra.: Marina Fuser Pillis

Instituição: CCTM - IPEN/CNEN -SP

Julgamento: Aprovado

Prof. Dr.: Jan Vatavuk

Instituição: UPM - Externo

Julgamento: Aprovado

Prof. Dr.: Alexandre Schalch Mendes

Instituição: Externo

Julgamento: Aprovado 


\section{Agradecimentos}

Este trabalho não poderia ser terminado sem a ajuda de diversas pessoas as quais presto minha homenagem:

Aos meus pais pelo incentivo em todos os momentos da minha vida.

A minha esposa e filho pelo apoio e compreensão nos momentos difíceis deste curso.

A minha orientadora, que me mostrou os caminhos a serem seguidos.

A todos os professores e colegas que ajudaram para a conclusão deste trabalho, em especial aos professores Arnaldo Homobono Paes de Andrade, Nelson Batista de Lima e Rene R. Oliveira.

A MWM Motores diesel e a Bleistahl pela oportunidade.

Aos amigos Ederson Andreatta, Carlos Pissaia, Mauro Roberto Souza Sobral, Hildebrando Pedro Brandão, Silvio Pereira e Diego Sene, pelas valiosas discussões técnicas e por todo o incentivo. 
"Quando não se pode fazer tudo o que se deve, deve-se fazer tudo o que se pode".

Publio Terêncio Afro 


\section{RESUMO}

PENHALBEL, Luciano T. B. Avaliação tribológica do par válvula e sede de válvula de admissão de um motor ciclo diesel em condições reais de funcionamento. 2017. 110 p. Dissertação (Mestrado em Tecnologia NuclearMateriais) - Instituto de Pesquisas Energéticas e Nucleares - IPEN-CNEN/SP. São Paulo.

A indústria automotiva exige produtos que trabalhem em condições extremas. $\mathrm{O}$ desenvolvimento de componentes é uma ação de aperfeiçoar os motores de combustão interna para que atinjam a vida requerida com níveis de desgaste aceitáveis, respeitando os limites legais de operação, como por exemplo, valores de emissões de poluentes. Diante dessas exigências, se faz necessário estudar componentes considerados críticos que conhecidamente influenciam no desempenho do motor. A tribologia do par válvula e sede de válvula de admissão é um importante conjunto que se deve ter atenção quanto ao seu desgaste, visto que pode influenciar na degradação do motor quanto aos parâmetros de emissões de poluentes e requisitos operacionais de manutenção e de vida do produto. $\mathrm{O}$ objetivo foi avaliar o comportamento do par tribológico, válvula e sede de válvula de admissão, submetidos a ensaios em dinamômetro e veiculares (condições reais de operação), quanto ao nível e tipo de desgaste ocorrido no par. Os resultados obtidos foram correlacionados com os requisitos de desempenho legais e operacionais de um motor ciclo diesel, como também foi realizada a caracterização do tipo de desgaste ocorrido no par tribológico e comparada com a literatura específica. Com base nos resultados, concluiu-se que ocorreu uma excelente compatibilidade entre a válvula e a sede da válvula de admissão; o nível de desgaste não prejudicou o desempenho do motor e as emissões de poluentes; o par tribológico atendeu aos requisitos de trabalho extremos, como operação em altas temperaturas e pressão de combustão com baixas taxas de desgaste; e os tipos de desgastes observados foram classificados como desgaste adesivo e sinais de deformação plástica.

Palavras-chave: Desgaste; Válvula; Sede de Válvula; Tribologia. 


\begin{abstract}
PENHALBEL, Luciano T. B. Tribological evaluation of intake valve and valve seat of a diesel cycle engine in real operating conditions. 2017. 110 p. Dissertação (Mestrado em Tecnologia Nuclear- Materiais) - Instituto de Pesquisas Energéticas e Nucleares - IPEN-CNEN/SP. São Paulo.
\end{abstract}

Automotive industry demands products that work under extreme conditions. The development of components for internal combustion engines is an action to improve this product, so that it reaches the required life with acceptable levels of wear and respecting the legal operating limits, such as values of emission pollutants. In view of these requirements, it is necessary to study components considered critical, which are known to influence the performance of the engine. So within this universe the tribology of the intake valve and valve seat insert is an important set, that must receive attention to its wear and consequently its influence to the engine degradation in the parameters of emission pollutants and performance related to the operational maintenance requirements and life of the product. The aim of this work is to evaluate the behavior of the tribological intake pair, valve and valve seat insert, submitted to dynamometer and vehicular tests (real operating conditions), regarding the level and type of wear occurred in the pair. The results were compared with legal and operational performance requirements of a diesel cycle engine, as well as the characterization of the wear type occurred in the tribological pair, with the related literature. Based on the results it was concluded that there was excellent compatibility between the valve and the valve seat material; the wear level did not impar the engine performance and emissions of pollutants; the tribological pair meeting extreme work requirements, such as high temperature operation and combustion pressure while maintaining low wear rates. The wear types observed were classified as adhesive wear and slight signs of shear strain wear.

Key words: Wear; Valve; Valve seat; Tribology. 


\section{LISTA DE TABELAS}

Tabela 1 - Distribuição de carga na válvula e sede de válvula (região de contato)

Tabela 2 - Influência do tipo de combustível na ação de desgaste do par tribológico válvula e sede de válvula. A avaliação da admissão e escape é referente a lubrificação do par válvula e sede de válvula de maneira qualitativa

Tabela 3 - Comparação de dureza típicas para válvulas e sede de válvulas .......39

Tabela 4 - Composição química da sede de válvula (\% em peso) ........................ 46

Tabela 5 - Equipamentos utilizados para análise metalúrgica das válvulas e sedes de válvulas

Tabela 6 - Limites de emissão de poluentes através do ciclo ESC ......................59

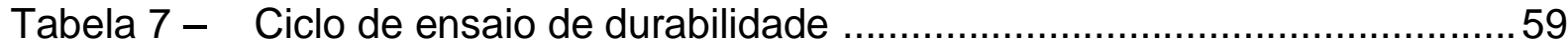

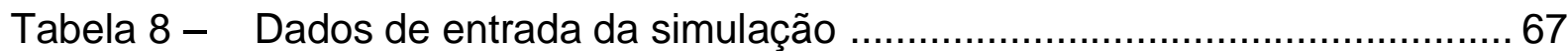

Tabela 9 - Resultados da análise metalográfica da válvula ...............................72

Tabela 10 - Resultados da análise química da válvula .......................................73

Tabela 11 - Resultados dos ensaios físicos da válvula ....................................... 73

Tabela 12 - Medição dimensional divididas por motor, visando garantir a conformidade das medições com o projeto da válvula ........................ 74

Tabela 13 - Resultados da análise metalográfica da sede de válvula ....................76

Tabela 14 - Resultados da análise química da sede de válvula ............................ 76

Tabela 15 - Medição dimensional divididas por motor, visando garantir a conformidade das medições com o projeto da sede de válvula montada no cabeçote

Tabela 16 - Medição dimensional inicial dos motores, visando garantir a conformidade das medições com o projeto. Os valores de regulagem de folga de válvula devem estar entre $0,2 \mathrm{~mm}$ até $0,4 \mathrm{~mm}$ e de profundidade inicial de $0,9 \mathrm{~mm}$ até $1,00 \mathrm{~mm}$

Tabela 17 - Resultados comparativos de emissões de poluentes (conforme resolução número 403 CONAMA - fase7). Resultado (Ensaio 1) antes de iniciar a durabilidade e (Ensaio 2) após a durabilidade

Tabela 18 - Desgaste do conjunto válvula e sede de válvula de admissão após ensaio de 2000 horas, que equivale à $200000 \mathrm{~km}$ 
Tabela 19 - Resultados da análise metalográfica das válvulas de admissão após ensaio em dinamômetro ........................................................... 85

Tabela 20 - Resultados da análise química após ensaio em dinamômetro ............86

Tabela 21 - Resultados dos ensaios físicos após ensaio em dinamômetro ............ 86

Tabela 22 - Resultados da análise metalográfica após ensaio em dinamômetro ...88

Tabela 23 - Resultados da análise química após ensaio em dinamômetro .............89

Tabela 24 - Valores de folga de válvula durante o ensaio de durabilidade veicular, após resfriamento do motor..................................................94

Tabela 25 - Desgaste do conjunto válvula e sede de válvula de admissão após ensaio de durabilidade veicular ...................................................... 94

Tabela 26 - Resultados da análise química da válvula, após durabilidade veicular

Tabela 27 - Resultados da análise metalográfico da válvula, após durabilidade veicular 103

Tabela 28 - Resultados da análise química da sede de válvula, após durabilidade veicular 104

Tabela 29 - Resultados da análise metalográfica da sede de válvula, após durabilidade veicular 


\section{LISTA DE FIGURAS}

Figura 1 - Os quatro tempos de um motor de combustão interna ....................... 26

Figura 2 - Diagrama de pressão no interior do cilindro .................................... 30

Figura 3 - Evolução da pressão de combustão em função das normas de emissões de poluentes. Para o motor objeto desse estudo

Figura 4 - Ângulo de assentamento formado entre válvula e sede de válvula .... 32

Figura 5 - Características e requerimentos das regiões da válvula ...................... 33

Figura 6 - Imagem em três dimensões de uma sede de válvula do motor

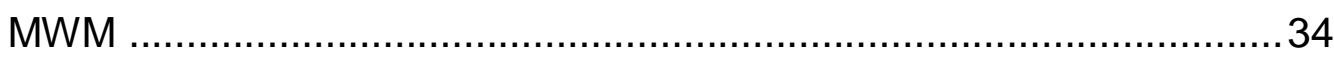

Figura 7 - Processo de obtenção de sedes sinterizadas .................................. 41

Figura 8 - Comparação entre diversos tipos de processos de manufatura para confecção componentes ......................................................... 42

Figura 9 - Dimensões principais da válvula de admissão ................................... 45

Figura 10 - Micrografia em microscópio óptico mostrando a estrutura da matriz carbonetos distribuídos fina e uniformemente, e uma fase intermetálica em uma matriz martensítica. Ataque: Nital 3\%. 46

Figura 11 - Dimensões principais da sede de válvula montada no cabeçote. Vale salientar que são duas sedes de válvula de admissão por cabeçote

Figura 12 - (a) trem de válvulas do motor ciclo diesel utilizado para avaliação

(b) detalhe, em corte transversal, do conjunto que foi avaliado

Figura 13 - Região de desgaste é onde ocorre o contato entre a válvula e a sede de válvula. Objeto de estudo evidenciado neste trabalho

Figura 14 - Parâmetros tribológicos relacionados ao par válvula e sede de válvula de admissão

Figura 15 - Motor diesel que foi utilizado durante os ensaios. Imagem em três dimensões

Figura 16 - Banco de testes equipado com dinamômetro utilizado para as avaliações das válvulas e sede de válvulas de admissão

Figura 17 - Modelo padrão de um relógio comparador 52

Figura 18 - (a) Medição das sedes e guia de válvulas em mesa tridimensional.

(b) Medição da profundidade da válvula com relação à face de fogo do cabeçote com relógio comparador. Este valor indica quanto ocorreu 
de desgaste do conjunto conhecendo os valores antes e após o teste de avaliação

Figura 19 - (a) Microscópio ótico utilizado para análise de microestrutura. (b) Microscópio eletrônico de varredura utilizado para análise de desgaste. Foto tiradas nas instalações da MWM Motores diesel (MWM, 2016)

Figura 20 - Sequência de atividades conduzidas para a evolução deste trabalho

Figura 21 - Relação entre os regimes de lubrificação e o atrito dos componentes de um motor de combustão interna (curva de Stribeck adaptada). Verifica-se que o conjunto válvula e sede de válvula de admissão se enquadram em uma condição limite de lubrificação, sendo no gráfico $\mu$ a viscosidade absoluta, $U$ a velocidade e $\mathrm{P}$ a carga unitária. 57

Figura 22 - Condições de durabilidade veicular ...............................................6 60

Figura 23 - Valores de potência, torque e consumo de combustível específico ....63

Figura 24 - Pressão de combustão máxima em função da rotação do motor 64

Figura 25 - Pressão de combustão em função do ângulo do virabrequim na condição de maior pressão de combustão do motor - 2200 rpm em plena carga 65

Figura 26 - Valores obtidos de temperaturas das válvulas de admissão do motor

Figura 27 - Através de análise de CAE foi verificado o movimento da válvula de admissão em relação a sede, com base nos dados de combustão, massa e rigidez do material (valores em milímetros)

Figura 28 - Análise de movimentação da cabeça da válvula em relação a sede, sendo que os tons em azul demostram nenhuma ou baixa movimentação e os tons em vermelho demostram as maiores movimentações (valores em milímetros)

Figura 29 - (a) Deflexão da cabeça da Válvula com diferentes ângulos de assentamento entre válvula e sede de válvula. (b) Pressão de contato entre válvula e sede de válvula com diferentes ângulos de assentamento entre válvula e sede de válvula

Figura 30 - Micrografia em microscópio óptico mostrando a estrutura da matriz 
na região da cabeça da válvula - martensitica com carbonetos bem distribuídos. Ataque: Água régia ..................................................... 72

Figura 31 - Micrografia em microscópio óptico da sede de válvula, mostrando a distribuição homogênea dos poros na matriz - poros cobertos com cobre. Ataque: sem ataque

Figura 32 - Micrografia em microscópio óptico da sede de válvula, mostrando a estrutura da matriz - carbonetos distribuídos fina e uniformemente, e uma fase intermetálica em uma matriz martensítica.

Ataque: Nital 3\%

Figura 33 - (a) mostra onde o relógio é referenciado (face do cabeçote) e a Figura (b) mostra qual é a região da válvula é verificada a profundidade da mesma em relação à face do cabeçote

Figura 34 - Checagem e regulagem de folga de válvula (a) mostra o operador verificando com lâmina a folga entre o balanceiro e a válvula e (b) mostra o detalhe da região

Figura 35 - Dados desempenho do motor (valores de potência ao longo do teste de durabilidade)

Figura 36 - Análise gráfica da probabilidade de desgaste referente aos conjuntos de válvula e sede de válvulas do ensaio de durabilidade em dinamômetro (valores médios de 0,2583 $\mu \mathrm{m}$ por $1000 \mathrm{~km}$ e desvio padrão de $0,0793 \mu \mathrm{m}$ por $1000 \mathrm{~km}$ )

Figura 37 - Fotografias mostrando o conjunto cabeçote testado (a), em detalhe as válvulas de admissão (b) e (c) as sedes de válvula, objetos de análise identificadas como "1" e "2"

Figura 38 - Macrografias em lupa estereoscópica mostrando os perfis da têmpera na região de contato entre a válvula de admissão e sede das peças 1 (a) e 2 (b) respectivamente - perfis em ordem após ensaio em dinamômetro. Ataque: Marble

Figura 39 - Micrografia em microscópio óptico mostrando a estrutura da matriz na região da cabeça - martensitica com carbonetos bem distribuídos, após ensaio em dinamômetro. Ataque: Água régia 85

Figura 40 - Micrografia em microscópio óptico mostrando a distribuição homogênea dos poros na matriz - poros cobertos com cobre, após ensaio em dinamômetro. Ataque: sem ataque 
Figura 41 - Micrografia em microscópio óptico mostrando a estrutura da matriz - carbonetos distribuídos fina e uniformemente, e uma fase intermetálica em uma matriz martensítica, após ensaio em dinamômetro. Ataque: Nital 3\%

Figura 42 - Análise através de espectroscopia por energia dispersiva (EDS) comparativa entre superfície de assento de válvula (a) e superfície da sede de válvula (b). Análise EDS realizada em corte transversal. Nota-se em (b), círculo vermelho, alta concentração de cobre originário da sede de válvula, após ensaio em dinamômetro 90

Figura 43 - A análise de superfície por MEV realizada no contato da válvula com a sede de válvula, que apontou características de desgaste Adesivo. O desgaste adesivo está relacionado com tensões de cisalhamento elevadas causadas pela fricção. Observou-se regiões cinzentas (c), com presença significativa do elemento cobre, vide Figura 44, material transferido da sede de válvula, após ensaio em dinamômetro 91

Figura 44 - Análise em MEV / EDS mostrando a presença do elemento cobre na válvula de admissão, após ensaio em dinamômetro

Figura 45 - A análise de superfície por MEV realizada sobre a superfície de contato da sede de válvula mostrou deformação plástica e pequenos destacamentos de material na superfície, após ensaio em dinamômetro 93

Figura 46 - Análise gráfica da probabilidade de desgaste referente aos conjuntos de válvula e sede de válvulas do ensaio de durabilidade veicular (valores médios de 0,2917 um por $1000 \mathrm{~km}$ e desvio padrão de $0,0793 \mu \mathrm{m}$ por $1000 \mathrm{~km}$ ) 95

Figura 47 - Perfil de desgaste mostrando em detalhe a região de contato da válvula (a) e na região e contato com da sede de válvula (b). Verificação realizada em perfilômetro - Pherthometer MAHR 97

Figura 48 - Análise gráfica da probabilidade de desgaste referente aos conjuntos de válvula e sede de válvulas dos ensaios de durabilidade em dinamômetro e veicular (valores médios de $0,275 \mu \mathrm{m}$ por $1000 \mathrm{~km}$ e desvio padrão de $0,0794 \mu \mathrm{m}$ por 
$1000 \mathrm{~km})$

Figura 49 - Ensaio de desgaste de um tipo de válvula contra vários tipos de sede de válvula de admissão (ensaio de bancada)

Figura 50 - (a) Face do cabeçote (b) Válvulas 1 e 2 do ensaio e (c) sedes de válvulas 1 e 2 após ensaio de durabilidade veicular. Foi escolhido um conjunto para analises metalúrgicas.

Figura 51 - Macrografias em lupa estereoscópica mostrando os perfis da têmpera na região de contato entre a válvula de admissão e sede das peças 1 (a) e 2 (b) respectivamente - perfis em ordem.

Ataque: Marble 102

Figura 52 - Micrografia em microscópio óptico mostrando a estrutura da matriz na região da cabeça da válvula,. Martensita revenida e carbonetos bem distribuídos. após ensaio de durabilidade veicular Ataque: Marble....103

Figura 53 - Micrografias (a) e (b) em microscópio óptico mostrando a estrutura da matriz - Martensita revenida com carbonetos finos distribuídos uniformemente e poros preenchidos com Cobre após ensaio de durabilidade veicular. Ataque: Nital 3\% 105

Figura 54 - Análise através de espectroscopia por energia dispersiva (EDS) comparativa entre superfície de assento de válvula (a) e superfície da sede de válvula (b). Análise EDS realizada em corte transversal. Nota-se em (b) alta concentração de cobre originário da sede de válvula, após ensaio de durabilidade veicular 107

Figura 55 - A análise de superfície por MEV realizada no contato da válvula com a sede de válvula, que apontou características de desgaste Adesivo. O desgaste adesivo está relacionado com tensões de cisalhamento elevadas causadas pela fricção. Observou-se regiões cinzentas (c), com presença significativa do elemento cobre (Cu), vide Figura 56, material transferido da sede de válvula, após ensaio de durabilidade veicular

Figura 56 - Análise em MEV / EDS mostrando a presença do elemento cobre (Cu) - material transferido da sede de válvula para a válvula, após ensaio de durabilidade veicular

Figura 57 - A análise de superfície por MEV realizada sobre a superfície de contato da sede de válvula mostrou deformação plástica e 
pequenos destacamentos de material na superfície - características de desgaste adesivo, após ensaio de durabilidade veicular.

Figura 58 - Micrografia da sede de válvula em microscópio óptico mostrando a estrutura da matriz da sede de válvula. Ataque: Nital 3\%

Figura 59 - Difratograma identificando fase intermetálica contida no material da sede de válvula (carboneto de cobalto molibdênio - $\mathrm{C}_{66} \mathrm{Mo6}_{6} \mathrm{C}_{2}$ ) entre outros elementos, conforme identificado e comparado na literatura (NEWSAM et al ,1988)

Figura 60 - O espaçamento interplanar do é o mesmo para todas as famílias de planos, em qualquer direção, quando o material está livre de tensões

Figura 61 - O espaçamento interplanar varia em todas as direções na presença de uma tensão.

Figura 62 - Direções da tensão e deformação principais 122

Figura 63 - Difratômetro utilizado para medição da tensão residual superficial (IPEN/CNEN-SP)

Figura 64 - Tensão residual superficial da sede de válvula. Medição realizada por difração de raio $\mathrm{x}$ na região de contato com a válvula de admissão 


\section{LISTA DE ABREVIAÇÕES E SIGLAS}

40NiCr6

AD

AGR

AISI

$\mathrm{Al}_{2} \mathrm{O}_{3}$

BSE

$\mathrm{C}$

CAD

CAE

$\mathrm{CaF}_{2}$

CATIA

CNEN

$\mathrm{CO}$

Co

$\mathrm{CO}_{2}$

CONAMA

$\mathrm{Cr}$

$\mathrm{Cu}$

$\mathrm{CV}$

DIN

EDS

ESC

FEA

$\mathrm{Fe}$

GVW

$\mathrm{HC}$

HRC

HSS

HV

IPEN

K
Aço Níquel Cromo

Anderson-Darling

Reatores avançados de refrigeração a gás

American Iron and Steel Institute

Óxido de Alumínio

Back-scattered electrons

Carbono

Computer Aided Design

Computer Aided Engineering

Fluoreto de Cálcio

Aplicação Interativa Tridimensional Auxiliada por

Computador

Conselho Nacional de Energia Nuclear

Monóxido de Carbono

Cobalto

Dióxido de Carbono

Conselho Nacional de Meio Ambiente

Cromo

Cobre

Cavalo Vapor

Deutsches Institut für Normung

Energy Dispersive X-Ray Spectroscopy

Ciclo Europeu em Regime Constante

Análise de Elementos Finitos

Ferro

Gross Vehicle Weight

Hidrocarbonetos

Escala de Dureza Rockwell

High Speed Stell

Escala de Dureza Vickers

Instituto de Pesquisas Energéticas e Nucleares

Temperatura em Kelvin 


\begin{tabular}{|c|c|}
\hline $\mathrm{km}$ & Quilômetros \\
\hline $\mathrm{kW}$ & quilo Watts \\
\hline m.kgf & Quilograma força x metro \\
\hline M2 & Aço rápido tipo M2 segundo AISI \\
\hline M35 & Aço rápido tipo $\mathrm{M} 35$ segundo AISI \\
\hline M4 & Aço rápido tipo M4 segundo AISI \\
\hline $\mathrm{M}_{6} \mathrm{C}$ ou $\mathrm{MC}$ & Carboneto (sendo M ferro, tungstênio e molibdênio) \\
\hline MEV & Microscópio Eletrônico de Varredura \\
\hline $\mathrm{mm}$ & Milímetros \\
\hline MnS & Sulfeto de Manganês \\
\hline Mo & Molibdênio \\
\hline $\mathrm{MoS}_{2}$ & Bissulfeto de Molibdênio \\
\hline MP & Material Particulado \\
\hline $\mathrm{MPa}$ & Mega Pascal \\
\hline MWM & Motoren-Werke Mannheim \\
\hline $\mathrm{N}$ & Newton \\
\hline $\mathrm{N} / \mathrm{mm}^{2}$ & Newton por milimetro ao quadrado \\
\hline $\mathrm{Ni}$ & Níquel \\
\hline $\mathrm{Nm}$ & Newton metro \\
\hline NO & Óxido nítrico \\
\hline $\mathrm{NO}_{2}$ & Dióxido de nitrogênio \\
\hline $\mathrm{NO}$ & Óxidos de Nitrogênio \\
\hline $\mathrm{OHC}$ & Over head camshaft \\
\hline $\mathrm{O}$ & Oxigênio \\
\hline $\mathrm{Pb}$ & Chumbo \\
\hline PFR & Prototype Fast Reactor \\
\hline PM & Metalurgia do Pó \\
\hline PMI & ponto morto inferior \\
\hline PMS & ponto morto superior \\
\hline \multirow[t]{2}{*}{ PROCONVE } & Programa de Controle da Poluição do Ar por Veículos \\
\hline & Automotores \\
\hline $\mathrm{RHT}$ & profundidade de dureza \\
\hline rpm & rotações por minuto \\
\hline SCR & selective catalytic reduction \\
\hline
\end{tabular}




$\begin{array}{ll}\text { SEI } & \text { secondary electron imaging } \\ \mathrm{Si} & \text { Silício } \\ \mathrm{SUV} & \text { Sport Utility Vehicle } \\ \mathrm{V} & \text { Vanádio } \\ \text { Valor - P } & \text { Valor da probabilidade } \\ \mathrm{W} & \text { Tungstênio } \\ \mathrm{W} / \mathrm{m} . \mathrm{K} & \text { Watt por metro por Kelvin } \\ \text { X50CrMnNiNbN 219 } & \text { Aço Cromo Manganês Níquel Nióbio } \\ \text { X85CrMoV18-2 } & \text { Aço Cromo Molibdênio Vanádio } \\ \text { um } & \text { micrômetro }\end{array}$




\section{SUMÁRIO}

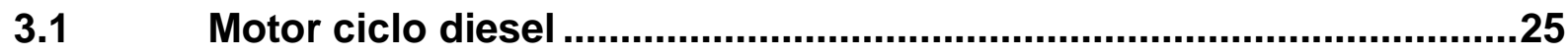

3.2 Emissão de gases de escape em motores diesel...............................26

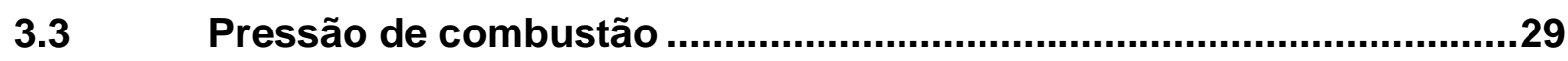

$3.4 \quad$ Válvulas e sedes de válvulas ............................................................32

3.5 Tribologia do par válvula e sede ............................................................

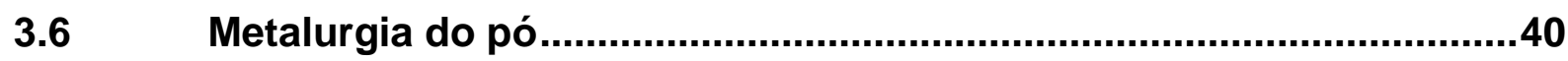

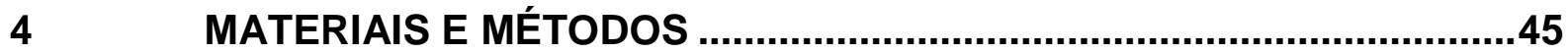

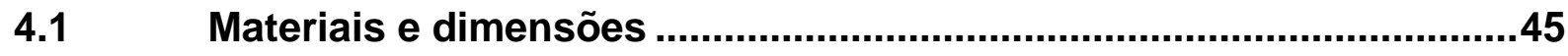

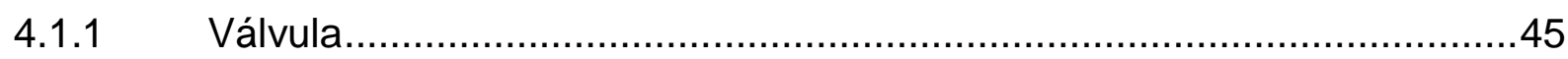

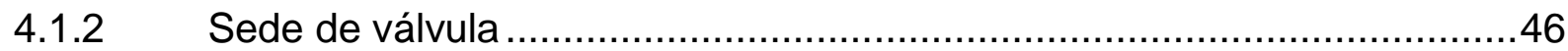

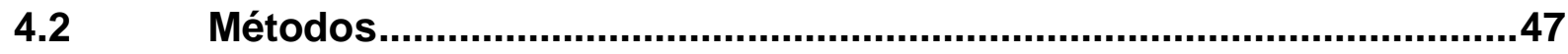

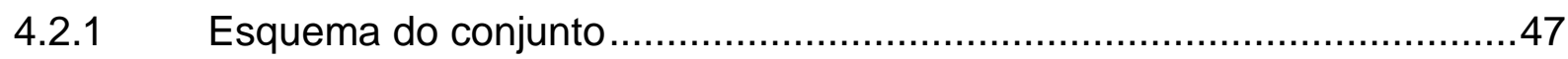

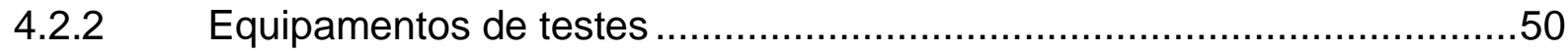

4.2.3 Equipamentos para avaliações dimensionais e metalúrgicas ...................51

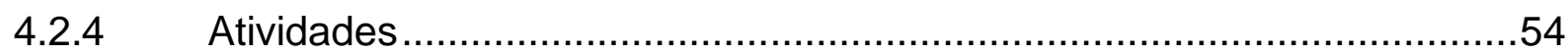

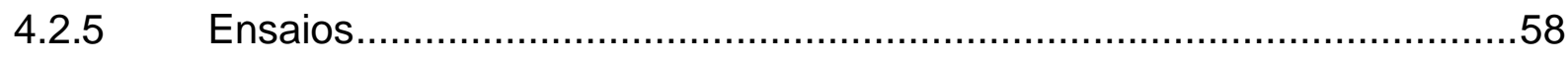

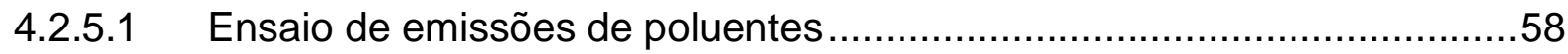

4.2.5.2 Ensaio de durabilidade em dinamômetro e veicular .................................59

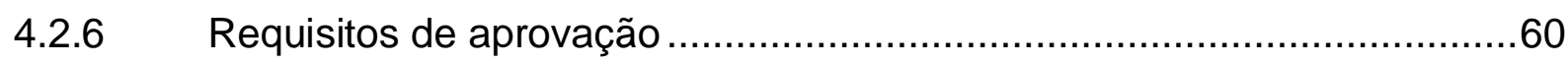

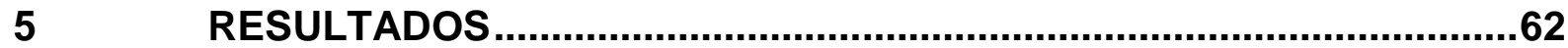

5.1 Coleta de dados de funcionamento do motor....................................62

5.1.1 Curva de potência, Torque e Consumo de Combustível ..........................62

5.1.2 Resultado de pressão de combustão .................................................64

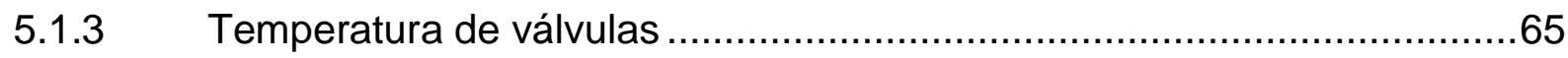

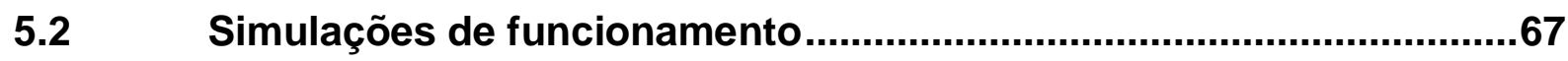

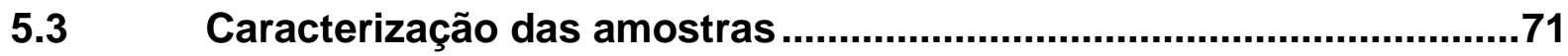

5.3.1 Caracterização das válvulas de admissão ............................................

5.3.2 Caracterização da caracterização das sedes de válvula ..........................74

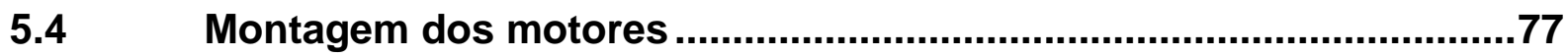

5.5 Resultado do ensaio de durabilidade em dinamômetro .......................79 
5.5.1 Análises de desempenho, emissões de poluentes e nível do desgaste...79

5.5.2 Análises metalúrgicas (propriedades dos materiais) ..............................82

5.5.3 Análise do tipo de desgaste (contato válvula e sede de válvula) .............89

5.6 Resultado do ensaio de durabilidade veicular...................................94

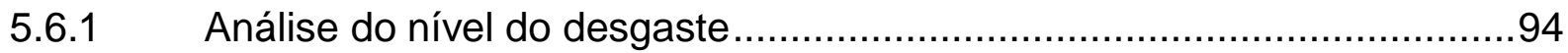

5.6.2 Análises metalúrgicas (propriedades dos materiais) ............................100

5.6.3 Análise do tipo de desgaste (contato válvula e sede de válvula) ...........106

$6 \quad$ CONCLUSÕES ............................................................................114

7 SUGESTÔES PARA TRABALHOS FUTUROS …................................116

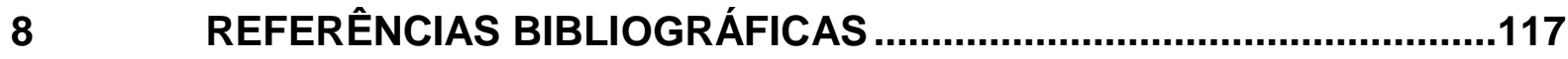

APÊNDICE A - Avaliação da deformação plástica nas sedes de

válvula através de difração de raio-x.................................................120 


\section{INTRODUÇÃO}

A indústria automobilística mostra uma forte tendência de diminuição dimensional de motores e maior eficiência específica. Isso ocorre basicamente devido à necessidade de redução de massa veicular para diminuição das emissões de poluentes e de consumo de combustível. Tal tendência faz com que seja necessário o uso de materiais mais leves e ao mesmo tempo resistentes às condições extremas de trabalho, principalmente por conta do aumento das pressões de combustão e temperaturas dos gases no cilindro (para melhor eficiência energética do motor) e pelo downsizing dos motores. O termo downsizing significa, no mundo automotivo, um motor com capacidade cúbica menor, porém com desempenho em termos de potência e torque semelhantes a um motor de capacidade cúbica maior (HIGA, 2011).

Motores ciclo diesel são usados em aplicações essenciais para a economia, tais como transporte rodoviário e urbano (ônibus e caminhões), setor agrícola (tratores, maquinários em geral), aplicações estacionárias (geradores de energia, compressores, moto-bombas), aplicações marítimas (embarcações diversas), bem como locomoção pessoal (veículos de passeio, pick-ups e SUVs).

O princípio de funcionamento dos motores ciclo diesel consiste em aspirar o ar num processo isobárico. Em seguida, ocorre um processo de compressão do ar de forma adiabática. Quando o pistão está no ponto morto superior ou próximo dele, o combustível é injetado de forma atomizada na massa de ar aquecida e comprimida. Nessas condições ocorre a queima do combustível sem necessidade de centelha, denominada de combustão espontânea. Este processo gera pressões elevadas dentro do cilindro do motor quando comparado com motores ciclo Otto, sendo que motores ciclo diesel mais modernos podem atingir mais de 200 bar de pressão de combustão (valores de pico).

As válvulas e sedes de válvulas para qualquer tipo de motor, seja ele ciclo diesel ou ciclo Otto, possuem a função de vedação da câmara de combustão, a fim de que a pressão necessária para a combustão seja alcançada. Portanto, estes componentes são muito importantes para uma queima homogênea com taxas de emissão de poluentes baixas. Para motores ciclo diesel, o par válvula e sede de válvula tem de satisfazer requisitos extremos, como temperaturas de operação 
acima de $500^{\circ} \mathrm{C}$, altas pressões de trabalho, baixas taxas de desgaste e boa usinabilidade.

Segundo RACOLTA (1995), tribologia é um termo que vem do grego e significa "ciência de fricção" (tribos = esfregar; logos = estudo). A partir de 1957, a tribologia foi reconhecida como uma ciência multidisciplinar situada na fronteira da mecânica dos sólidos e dos fluídos e engloba os fenômenos de atrito, desgaste e lubrificação.

O desgaste excessivo do par válvula e sede de válvula de admissão causa a mudança em parâmetros da combustão do motor, levando a diminuição do desempenho e a alterações nos valores de emissões de poluentes, conforme BASSHUYSEN e SCHAFER (2004). No Brasil, como em outras partes do mundo, existem estudos e aplicações de sede de válvulas confeccionadas pela metalurgia do pó, com a intenção de trazer vantagens competitivas tanto no aspecto comercial, relacionado a diminuição de custos, conforme EUROPEAN POWDER METALLURGY ASSOCIATION (2017), como também no aspecto técnico, por apresentar melhor compatibilidade tribológica (LAKSHMINARAYANAN e NAYAK, 2011).

Existem poucas publicações técnicas em condições reais de funcionamento relacionado ao par tribológico válvula e sede de válvula, sobretudo sobre o par de admissão. Com isso, este trabalho pretende preencher esta lacuna com informações práticas e teóricas sobre o comportamento deste par.

A motivação para execução deste trabalho vem pela demanda das indústrias de veículos automotores por produtos que trabalhem, cada vez mais, em condições extremas, devido às metas já anteriormente mencionadas. O desenvolvimento de componentes para motores de combustão interna visa aperfeiçoar este produto para que atinja a vida requerida com níveis de desgaste aceitáveis, além de respeitar os limites legais de operação, como os valores de emissões de poluentes. Diante dessas exigências, se faz necessário estudar os componentes considerados críticos, que conhecidamente influenciam no desempenho do motor. Dentro deste universo, a tribologia do par válvula e sede de válvula de admissão é um importante conjunto. O conhecimento do seu desgaste é fundamental para saber sua influência em relação à degradação do motor nos parâmetros de emissões de poluentes e desempenho relacionados aos requisitos operacionais de manutenção e vida do produto. 
Os componentes válvula e sede de válvula de admissão foram caracterizados antes e após os testes, por microscopia óptica e eletrônica de varredura, espectrometrias de emissão óptica, análises de dureza e avaliações dimensionais, para avaliação do nível e da maneira em que ocorreu o desgaste do par citado.

A abrangência do trabalho é voltada para motores de combustão interna, ciclo diesel, quatro tempos e aplicação heavy duty, com foco no par tribológico válvula e sede de válvula de admissão.

O estudo é delimitado pelo uso de um único tipo de válvula e sede de válvula de admissão, sendo a sede de válvula confeccionada pelo processo de metalurgia do pó por apresentar vantagens competitivas, tanto no âmbito técnico, quanto no comercial. Para a execução das atividades foram utilizadas válvulas de admissão e sedes de válvulas conforme recebido da indústria.

Os métodos de caracterização do desgaste de componentes e sua influência no comportamento de um equipamento, qualquer que seja, são de extrema importância para conhecimentos funcionais de um produto em todas as áreas de tecnologia. Desta forma, o conhecimento apresentado neste trabalho pode ser aplicado ao universo de geração de energia nuclear. Conforme ROBERTS (1981) os tribólogos têm um papel importante a desempenhar na geração de energia nuclear, desde o enriquecimento do combustível de urânio, passando pelo funcionamento do reator, reprocessamento do combustível irradiado até a eliminação de resíduos ativos dos produtos de fissão. Para citar exemplos, desde o programa de desenvolvimento de reatores do tipo Magnox através de reatores avançados de refrigeração a gás (AGRs), até o Prototype Fast Reactor (PFR), as potências de combustíveis e as temperaturas do refrigerante aumentaram significativamente e para os reatores rápidos, a tecnologia de refrigeração mudou de gás para metal líquido (sódio). Todas estas mudanças estabeleceram problemas tribológicos difíceis e desafiadores para os engenheiros e cientistas de materiais. 


\section{OBJETIVO}

O objetivo do trabalho é avaliar o comportamento do par tribológico, válvula e sede de válvula de admissão, submetidos a ensaios em dinamômetro e veiculares (condições reais de operação), quanto ao nível e tipo de desgaste ocorrido no par. Os resultados obtidos foram correlacionados com os requisitos de desempenho legais e operacionais de um motor ciclo diesel, bem como caracterizado o tipo de desgaste ocorrido no par tribológico, segundo a literatura relacionada. 


\section{CONCEITOS FUNDAMENTAIS}

\subsection{Motor Ciclo diesel}

Historicamente, em 1893, Rudolf Christian Karl Diesel, francês, engenheiro, inventou o tipo de motor que hoje leva seu nome: motor diesel, conforme NITSCKE e WILSON (1985). O motor diesel é uma máquina térmica que transforma energia química ligada ao combustível em calor e o calor em trabalho mecânico (BRUNETTI, 2012).

Os motores de autoignição ou também denominados de ignição espontânea são os motores de combustão ciclo diesel. O combustível é injetado pulverizado diretamente na câmara de combustão, no fim do ciclo de compressão, com o ar pressurizado e aquecido misturando-se ao combustível (óleo diesel), ocorrendo a combustão espontânea (Figura 1).

Quanto ao número de tempos do ciclo de operação, em motores de quatro tempos o pistão percorre quatro vezes o seu curso para que seja cumprido um ciclo, lembrando que tempo é um curso do pistão, por isso quatro tempos. Os quatros tempos são os seguintes:

Admissão: o pistão se movimenta do ponto morto superior (PMS) ao ponto morto inferior (PMI). Durante quase todo o ciclo de admissão, o ar filtrado é induzido para dentro do cilindro.

Compressão: o ar que foi induzido para dentro do cilindro é comprimido durante a movimentação do pistão do PMI para o PMS. No caso dos motores ciclo diesel o ar existente dentro do cilindro é comprimido e aquecido a uma temperatura normalmente acima da temperatura de autoignição do combustível, sendo que o combustível é injetado no cilindro próximo ao PMS.

Expansão: com a queima do combustível, a energia em forma de calor é liberada aumentando a pressão dentro do cilindro. Esta liberação de energia aumenta a pressão no cilindro que é aplicada a superfície do pistão fazendo com que ele retorne ao PMI, e neste ciclo que a expansão dos gases produz trabalho aplicando pressão a superfície do pistão. 
Exaustão: também denominado escape, é o tempo onde os produtos da combustão são expelidos para o sistema de escape e consequentemente para a atmosfera.

Na Figura 1, mostra-se o esquema dos ciclos de um motor quatro tempos.

Figura 1 - Os quatro tempos de um motor de combustão interna.

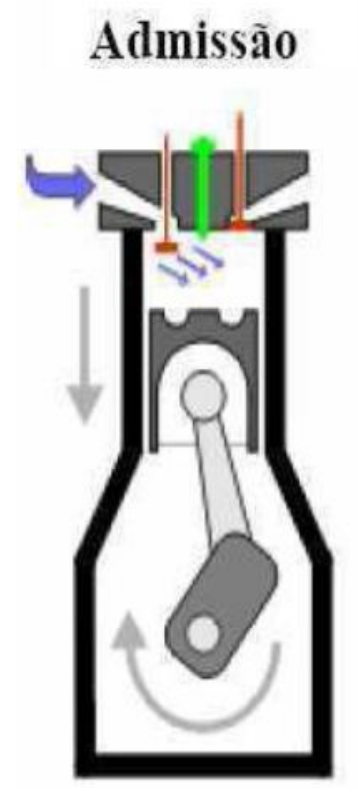

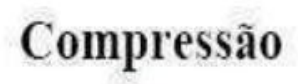

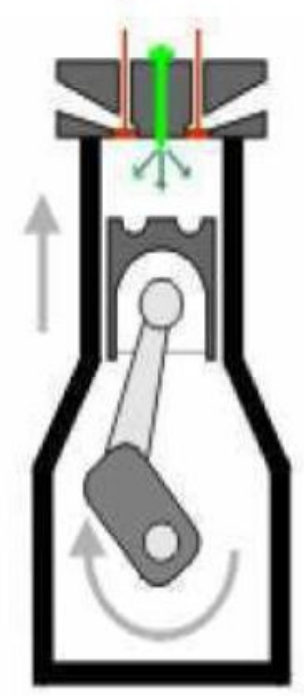

Expansão

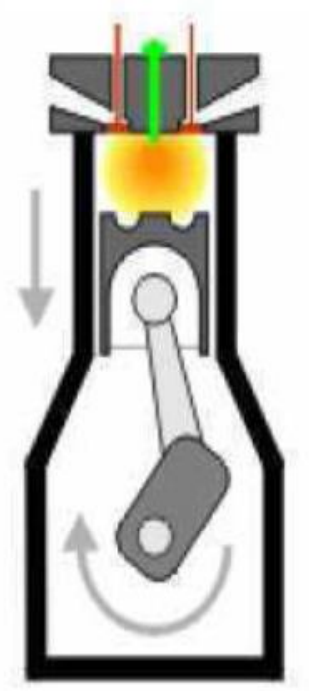

Exaustão

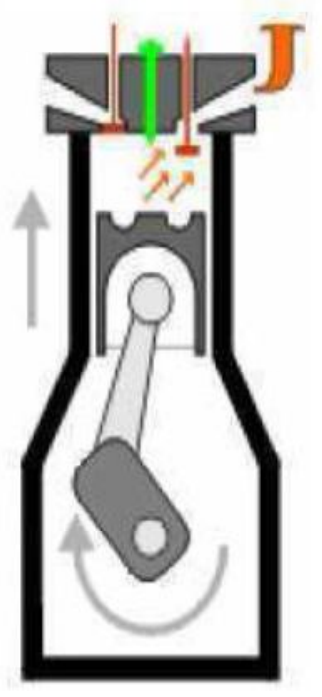

Fonte: LOURENÇO, 2010.

É importante mencionar que a ignição espontânea começa localmente em áreas com o combustível completamente vaporizado e misturado com oxigênio em quantidade suficiente, conforme (BASSHUYSEN e SCHAFER, 2004).

\subsection{Emissão de gases de escape em motores diesel}

A combustão no motor diesel gera, além de outros aspectos, a emissão de gases. Os principais gases e resíduos da combustão são apresentados a seguir, conforme (LOURENÇO, 2010):

Hidrocarbonetos $(\mathrm{HC})$ : consistem basicamente de moléculas de combustível decompostas e óleo lubrificante. As principais fontes das moléculas de combustível decompostas, são a mistura ar e combustível e tamanho excessivo de partículas (gotas) de combustível geradas ao final da injeção. Em geral, hidrocarbonetos não queimados são relacionados à região de mistura ar e combustível relativamente rica, geometria do spray de combustível, quantidade de 
combustível injetada nas paredes do cilindro e pós-injeção. Obviamente, o projeto do motor e as condições de operação têm também um papel importante na formação e oxidação das moléculas de hidrocarbonetos (LOURENÇO, 2010).

Monóxido de Carbono (CO): é um produto intermediário da combustão dos hidrocarbonetos. Formado principalmente devido à combustão incompleta que ocorre devido à falta de oxidantes e às baixas temperaturas. Durante a combustão, quando esta ocorre de forma completa, ocorre a oxidação de $\mathrm{CO}$ em $\mathrm{CO}_{2}$ por reações entre o $\mathrm{CO}$ e $\mathrm{O}$. Se estas reações são incompletas devido à falta de oxidantes ou devido à baixa temperatura, não ocorre a oxidação do $\mathrm{CO}$, fazendo assim com que o motor emita grandes quantidades deste gás.

A combustão de misturas ar e combustível ricas normalmente, produzem grandes quantidades de $\mathrm{CO}$, mas como a combustão em motores diesel é normalmente pobre, e tem ar em abundância, as emissões de CO nos motores diesel são extremamente baixas.

Óxidos de Nitrogênio ( $\mathrm{NO}_{\mathrm{x}}$ ): nas emissões de gases em motores diesel, o óxido nítrico (NO) é normalmente o mais abundante óxido de nitrogênio e constitui de $70 \%$ a $90 \%$ do total de NOx. O Dióxido de nitrogênio $\left(\mathrm{NO}_{2}\right)$ também aparece em níveis significativos. Para os dois compostos principais das emissões de NOx, o NO formado a partir do processo de combustão e o $\mathrm{NO}_{2}$ formado a partir do NO. Existem vários mecanismos responsáveis pela formação do NO durante o processo de combustão, e estes mecanismos são fortemente afetados pela temperatura, pressão, condições da chama e concentrações dos demais componentes na combustão (LOURENÇO, 2010).

Aumentar a carga em motores diesel, naturalmente aspirados, implica em um aumento na quantidade de combustível injetada para a mesma quantidade de ar induzida a uma rotação constante. Quanto maior a quantidade de combustível queimado, mais calor é gerado e pode-se observar um aumento significativo de temperatura no cilindro. Maiores temperaturas produzem energia suficiente para que ocorram os mecanismos de reações químicas, causando assim maiores formações de NOx (LOURENÇO, 2010).

Aumentando-se a pressão de injeção, tende-se a melhorar a atomização do combustível. A presença de partículas menores devido a uma melhor atomização, melhora a eficiência da combustão, liberando assim maior quantidade 
de calor e consequentemente aumentando a temperatura no cilindro. Em geral, altas temperaturas levam a maiores formações de NO.

Material Particulado (MP): definido como qualquer partícula presente no sistema de escape de um motor de combustão interna que pode ser retida em um filtro, com temperaturas iguais ou inferiores a $52^{\circ} \mathrm{C}$. Assim o material particulado não é uma espécie fisicamente bem definida.

Em geral, o material particulado é obtido a partir de substâncias orgânicas e inorgânicas induzidas ao motor junto ao ar e ao combustível. Os principais constituintes do material particulado são as partículas de carbono resultantes dos processos de combustão heterogêneos nos motores diesel. Poeira, presente no ar ambiente ou material inorgânico presente nos combustíveis ou nos aditivos podem aparecer como forma de material particulado no sistema de escape. Também, metais provenientes de desgaste dos componentes do motor podem ser levados pelo óleo lubrificante e eventualmente migrarem para o sistema de escape onde podem ser retidos no filtro de material particulado (LOURENÇO, 2010).

A presença de enxofre no combustível e óleo lubrificante contribui para a formação das partículas de sulfato que por sua característica de reter umidade, podem dobrar a sua massa, aumentando assim a quantidade do material particulado retido no filtro.

Finalmente, hidrocarbonetos evaporados e seus derivados são também incluídos nas emissões de material particulado. Esta fração, também chamada de fração orgânica solúvel, e composta basicamente de derivados de óleo lubrificante presentes nos hidrocarbonetos.

O óleo lubrificante presente na câmara de combustão proveniente de desgaste excessivo na parede do cilindro e desgaste de anéis de pistão pode ser a fonte principal de consumo de óleo lubrificante nos motores diesel, além da sua enorme contribuição para a presença de óleo lubrificante não queimado na fração de material particulado, constituindo também a fração orgânica solúvel.

A presença de fumaça no sistema de escape dos motores diesel são um indicativo de uma combustão pobre, resultante de uma relação ar e combustível extremamente baixa ou combustível parcialmente evaporado, durante condições de partida a frio. A emissão de fumaça, especialmente quando na forma de fumaça preta e um dos principais vilões dos motores diesel, dando a eles a reputação de serem motores extremamente sujos (LOURENÇO, 2010). 
A fumaça pode estar em forma de partículas, tanto sólidas como líquidas suspensas nos gases presentes no sistema de escape dos motores diesel, obstruindo e refletindo a luz, bem como limitando sua visibilidade. A fumaça pode ser classificada como:

Branca: consistindo em uma mistura de combustível e partículas de óleo lubrificante não queimadas. Este tipo de fumaça é geralmente chamado de fumaça líquida.

Preta: consistindo em partículas sólidas de carbono resultado de uma combustão completa do combustível. Este tipo de fumaça é geralmente chamado de fumaça sólida ou fumaça quente.

Com relação ao desgaste do par tribológico válvula e sede de válvula de admissão, uma vez que o par apresente desgaste excessivo, este pode influenciar na perda de compressão do cilindro, tal consequência conforme verificado nas explicações de cada poluente gerado pela combustão do motor afetam negativamente os mesmos, uma vez que a perda de compressão do cilindro está diretamente vinculada a uma combustão homogênea.

\subsection{Pressão de Combustão}

A pressão de combustão é a pressão gerada no interior do cilindro do motor decorrente do processo de combustão. Na Figura 2, mostra-se a pressão de combustão em função do ângulo de rotação do eixo virabrequim. 
Figura 2 - Diagrama de pressão no interior do cilindro.

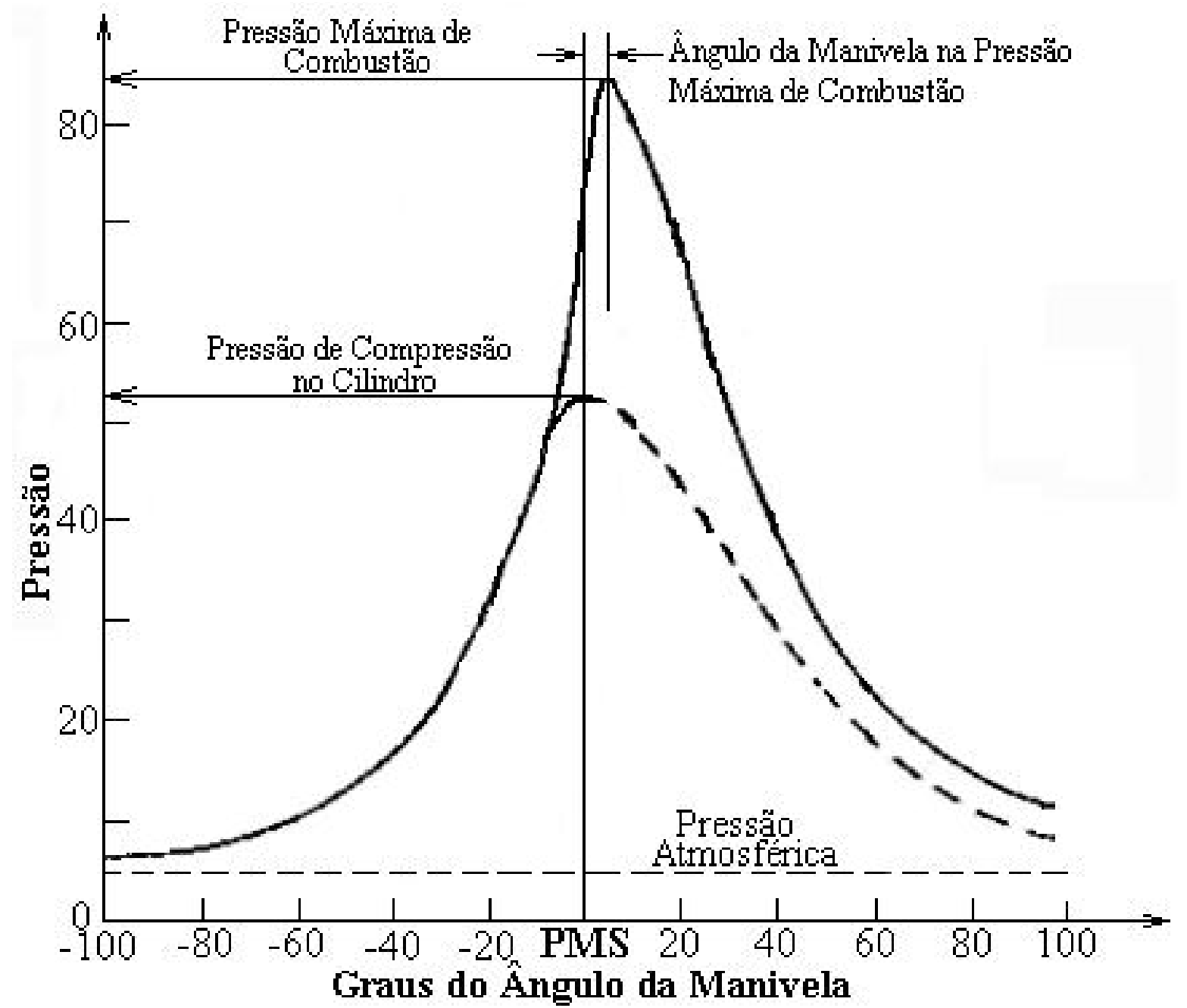

Fonte: COELHO e BELCHIOR, 1999.

Para efeito de dimensionamento de componentes, utiliza-se normalmente a pressão máxima de combustão, indicada na Figura 2 como exemplo. $O$ dado de pressão de combustão pode ser obtido através de simulações, ou coletado na prática através de instrumentações realizadas no cabeçote do motor, que o ligam ao cilindro, onde é adaptado um transdutor de pressão realizando leituras equivalentes às faixas de pressão de combustão em que o motor opera.

Na Figura 3, mostra-se a evolução da pressão de combustão em motores diesel em função das normas de emissões de poluentes ao longo do tempo. Os valores apresentados na Figura 3 são referências do motor objeto desse estudo, contudo este dado pode mostrar alterações conforme o tipo de motor. 
Figura 3 - Evolução da pressão de combustão em função das normas de emissões de poluentes. Para o motor objeto desse estudo.

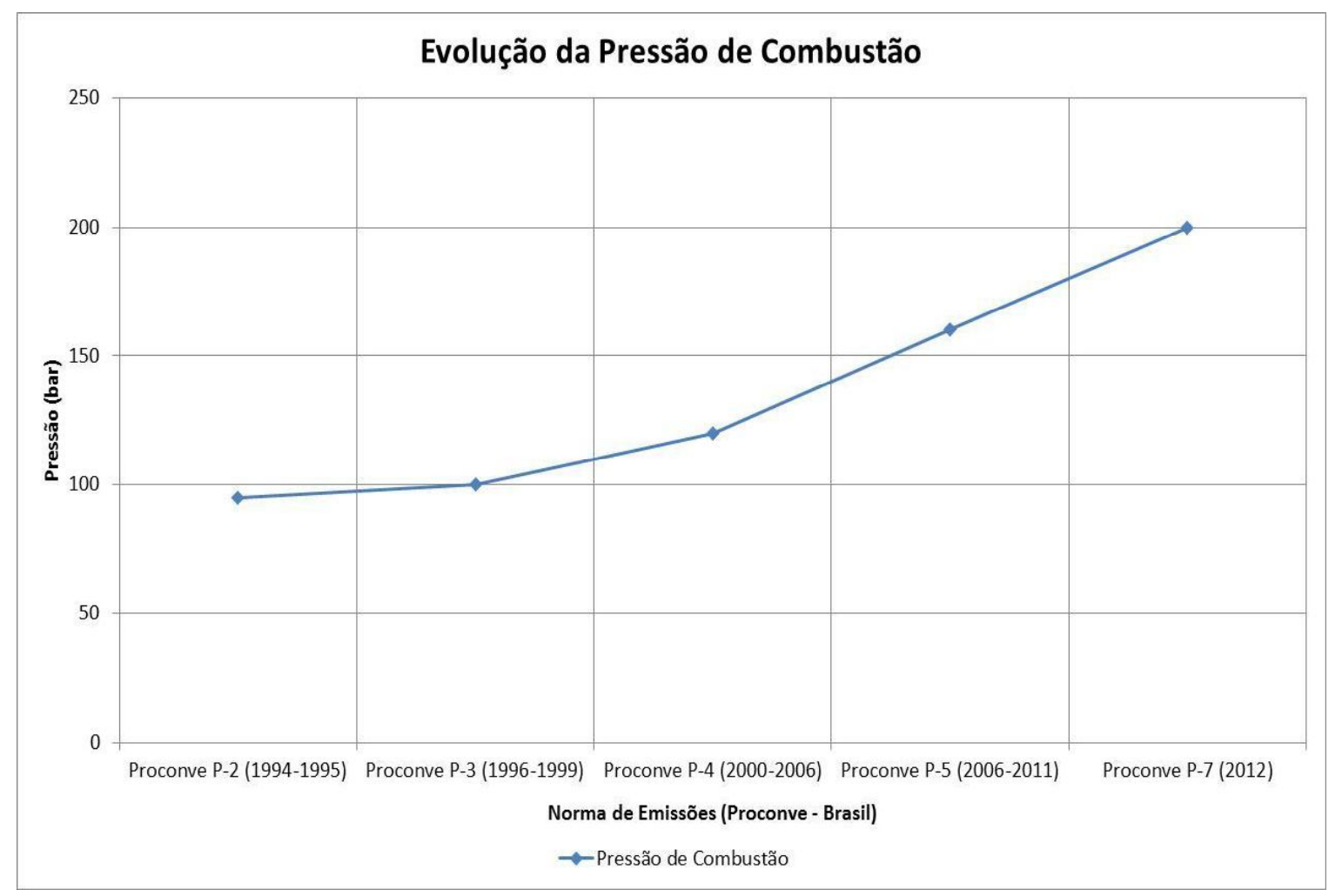

Fonte: autor da dissertação.

A pressão de combustão e o comportamento do par tribológico válvula e sede de válvula estão relacionados através da expressão que calcula a força de assentamento $(F)$, adaptado conforme (WANG, 2007):

$$
F=\frac{(P . A)}{\cos \propto}
$$

Onde:

$\mathrm{P}=$ Pressão de Combustão máxima

$A=$ Área da face da válvula

$\alpha=$ Ângulo de assentamento da válvula

$\mathrm{Na}$ Figura 4, mostra-se o ângulo de assentamento formado entre válvula e sede de válvula. Este ângulo influencia diretamente na pressão de contato entre válvula e sede de válvula, bem como na deflexão da válvula. 
Figura 4 - Ângulo de assentamento formado entre válvula e sede de válvula.

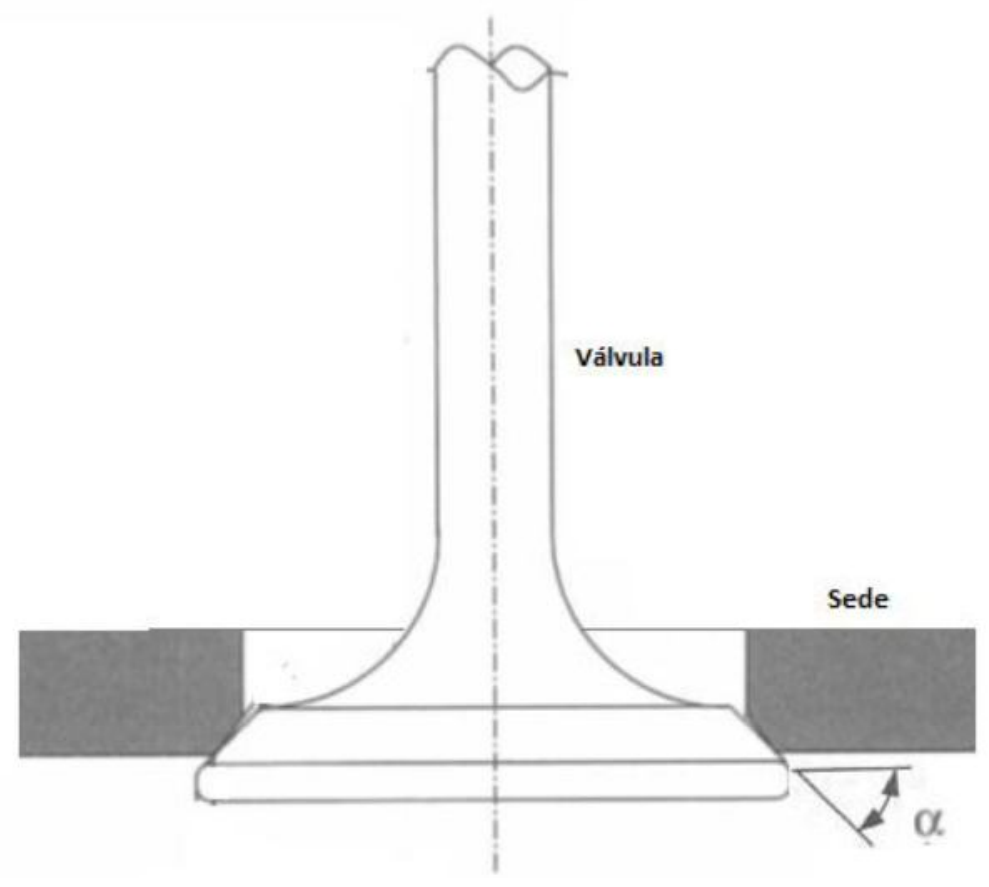

Fonte: Adaptado de WANG, 2007.

\subsection{Válvulas e sedes de válvulas}

Conforme BASSHUYSEN e SCHAFER (2004), válvulas de motores de combustão interna funcionam em condições extremas, com altas temperaturas e elevadas pressões de trabalho, além disso, este componente deve apresentar uma grande precisão dimensional. A válvula pode ser dividida em três áreas: a extremidade da haste, a haste e a cabeça da válvula. A extremidade da haste é onde ocorre o contato com o balanceiro, que através do mecanismo do trem de válvula transmite força para o acionamento da válvula. A haste de válvula é guiada no cabeçote do motor e transfere parte do calor, cerca de $24 \%$ conforme HEISLER (1995). A cabeça da válvula fecha a abertura do cabeçote, quando em contato com a sede de válvula, que também transfere a maior parte do calor, cerca de $70 \%$ conforme HEISLER (1995). Na Figura 5, fornece-se uma visão geral das necessidades e características específicas para cada área da válvula conforme (GEBAUER, 2006). 
Figura 5 - Características e requerimentos das regiões da válvula.

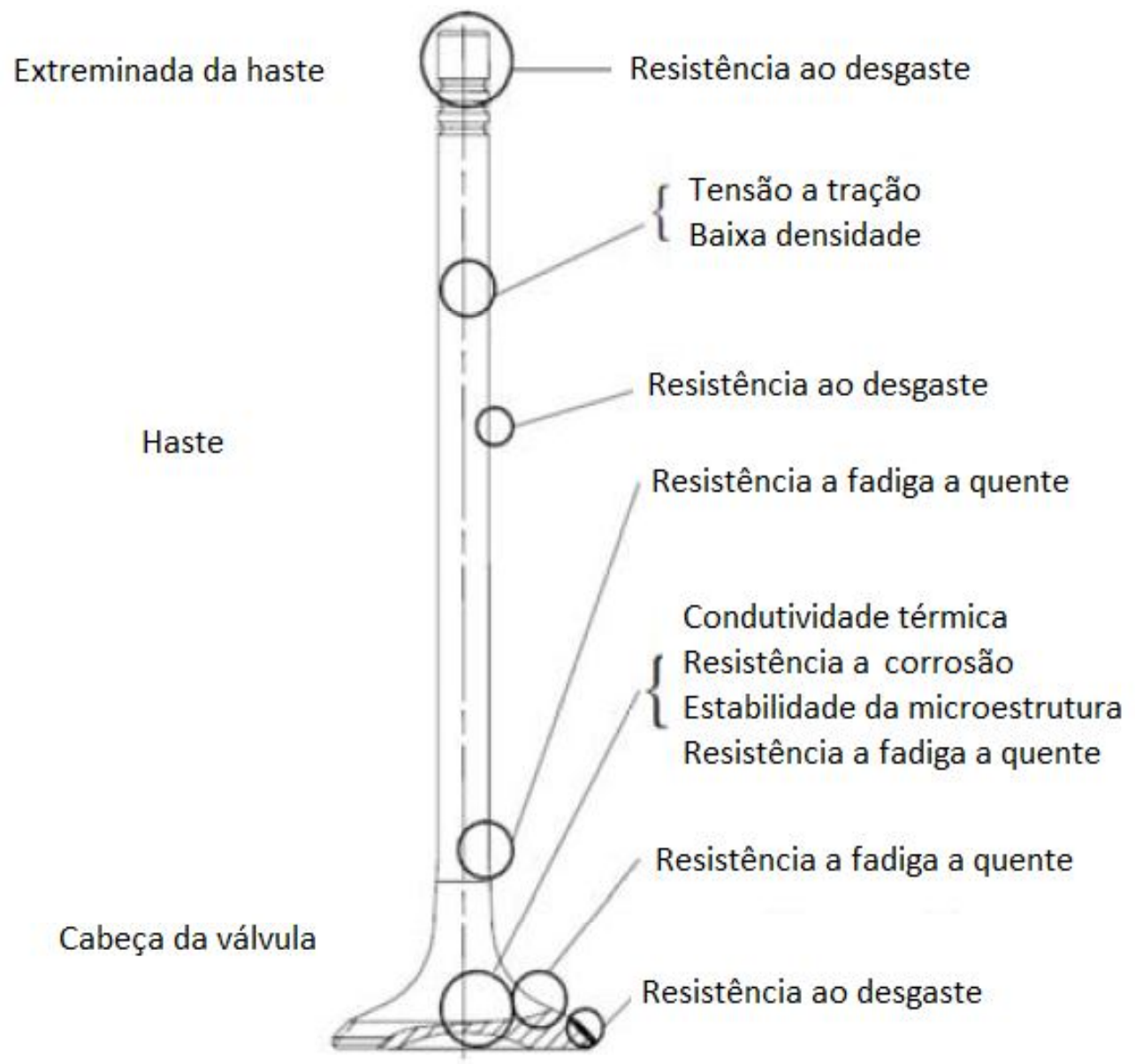

Fonte: Adaptado de GEBAUER, 2006.

Segundo BASSHUYSEN e SCHAFER (2004) as sedes de válvulas são componentes importantes dentro do sistema de trem de válvulas, sendo essencial para a perfeita ignição e combustão dentro do cilindro. Juntamente com a válvula este componente deve assegurar uma completa vedação da câmara de combustão para as pressões de compressão e combustão requeridas.

$\mathrm{Na}$ Figura 6, ilustra-se uma sede de válvula aplicada em motores. As principais propriedades que uma sede de válvula deve possuir são:

1. Dureza a quente;

2. Estabilidade térmica;

3. Coeficiente de expansão térmica similar ao do cabeçote;

4. Condutividade térmica;

5. Resistência à oxidação e à corrosão;

6. Resistência ao desgaste;

7. Usinabilidade. 
Figura 6 - Imagem em três dimensões de uma sede de válvula do motor MWM.

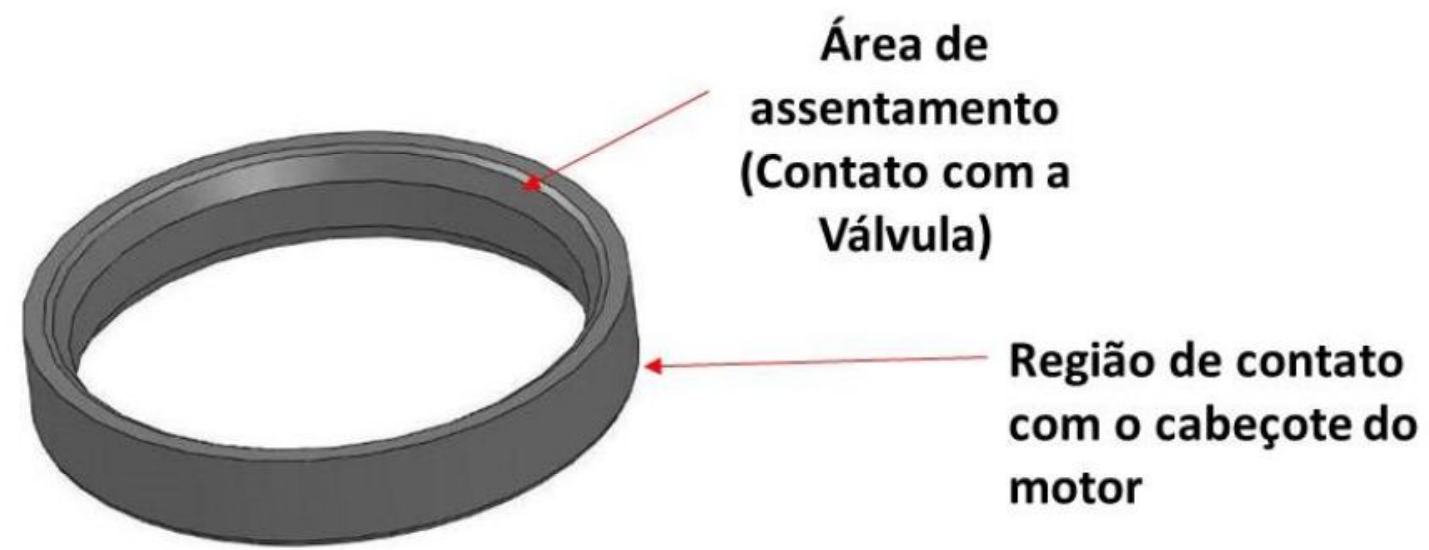

Fonte: autor da dissertação.

Segundo BASSHUYSEN e SCHAFER (2004) materiais de sede de válvula devem apresentar certas propriedades para satisfazer os requisitos de tecnologia dos materiais. As propriedades principais são descritas a seguir:

1. Dureza a quente: geralmente indica a resistência ao desgaste a temperaturas elevadas. Valores de queda na dureza do material da sede de válvula com o aumento das temperaturas de trabalho podem apontar para os limites potenciais de temperatura para uma determinada aplicação.

2. Estabilidade térmica estrutural: isto indica alterações no material que ocorre sob a influência da temperatura. Os efeitos distintos encontram-se resumidos abaixo:

- Temperaturas entre $-190^{\circ} \mathrm{C}$ e $21^{\circ} \mathrm{C}$ pode ter o efeito de aumento da dureza e alteração dimensional, devido ao processo de conversão de residual de austenita em martensita;

- Temperaturas entre $250^{\circ} \mathrm{C}$ e $900^{\circ} \mathrm{C}$ pode ter efeito de mudança da dureza, mudança nas propriedades e mudança na estrutura do material. Espera-se de materiais que apresentam estruturas temperadas modificações relacionadas com a difusão, devido à carga térmica.

3. Coeficiente de expansão térmica: é desejado que as sedes de válvulas e cabeçotes de cilindro apresentam coeficientes de expansão térmica semelhantes, porque eles são fixados um ao outro por meio de interferência. Se este não for o caso, o aumento de temperatura pode provocar a redução das tensões de fixação, o que pode ocasionar na soltura da sede de válvula.

4. Condutividade térmica: a temperatura da válvula deve se manter dentro de limites razoáveis, é necessário assegurar uma boa transferência de calor a partir da 
válvula através da sede de válvula para a cabeçote do cilindro. Isto é conseguido pela alta condutividade térmica dos materiais. Cerca de $70 \%$ a $85 \%$ do total de calor é transferido para o cabeçote através da sede de válvula e 15\% a 30\% por meio da guia de válvula. Cálculos teóricos mostraram que um aumento na condutividade de $20 \mathrm{~W} / \mathrm{m} . \mathrm{K}$ a $40 \mathrm{~W} / \mathrm{m}$.K reduz a temperatura de trabalho na sede da válvula na ordem de $50 \mathrm{~K}$ e na válvula na ordem de até $30 \mathrm{~K}$. Medições em motores distintos confirmaram esta redução na temperatura da cabeça da válvula. Aços de média-liga infiltrado com cobre são especialmente adequados para garantir essas características. Neste caso, o projeto do cabeçote de cilindro tem de considerar o fluxo de calor mais elevado, o que pode reduzir a resistência do material do mesmo. Esta sobrecarga térmica pode provocar trincas do material.

5. Densidade aparente: a fim de manter as tensões nos materiais tão baixas quanto possível, materiais com maior densidade são favoráveis devido à sua área de contato específica mais elevada em qualquer nível de carga. Isso também evita o efeito de entalhe dos poros que pode iniciar a fadiga, culminando no rompimento do material. Deve-se esperar certo volume de poros em produtos de metalurgia em pó.

6. A resistência à oxidação e à corrosão: devido às condições extremas de operação, como por exemplo, a alta temperatura, o material deve apresentar alta resistência à oxidação e à corrosão. Isto pode ser conseguido, quer por alteração da composição química ou por um material de passivação cuidadosa da superfície do componente por pré-oxidação.

7. Resistência ao desgaste: os seguintes mecanismos de desgaste podem ocorrer:

7.1 Adesão: microweldings locais com fuga subsequente nos pontos de contato. Os materiais são transferidos de uma superfície de interface para a outra, e pode ocorrer corrosão também.

7.2 Abrasão: remoção de material através do atrito na ordem dos micrômetros (menor que $10 \mu \mathrm{m}$ ). Material é transferido até um grau limitado.

7.3 Oxidação: formação de camadas de óxidos frágeis. Estas camadas irão se romper estando sob tensão.

7.4 Corrosão: a formação de fases reativas. No caso de materiais que contêm quantidades elevadas de níquel, a formação do eutético 
níquel-enxofre com baixo ponto de fusão conduz a uma menor resistência mecânica ou mesmo para o rompimento das peças de menor dimensão.

8. Usinabilidade: além da resistência ao desgaste, boa usinabilidade é um critério muito importante para os materiais a serem aplicados em sedes de válvula. As tolerâncias no cabeçote do cilindro e da sede de válvula devem ser usinadas após a montagem. A estrutura do material, a densidade e a adição de lubrificantes sólidos podem aumentar a vida útil da ferramenta.

\subsection{Tribologia do par válvula e sede}

Segundo RADI (2007) o termo tribologia, que vem do grego Tpıßo (Tribo esfregar) e $\Lambda$ oyo (Logos - estudo) foi utilizado, oficialmente, pela primeira vez em 1966 em um relatório feito por $\mathrm{H}$. Peter Jost para o comitê do departamento inglês de educação e ciência. Neste relatório, o termo foi definido como a "ciência e tecnologia de superfícies interativas em movimento relativo e dos assuntos e práticas relacionados" (JOST, 1990).

Segundo BRUNETTI (2012), sob o ponto de vista tribológico, as propriedades da superfície, e não "bulk" do material é que definem a sua utilização. Em geral evita-se o uso do mesmo material em dois corpos em contato relativo.

Tribologia, que abrange atrito, desgaste e lubrificação entre superfícies em movimento relativo, é um novo campo da ciência definida em 1967 por uma comissão da Organização para a Cooperação e Desenvolvimento Econômico, conforme STACHOWIAK e BATCHELOR (2013). Desgaste pode ser definido como a perda progressiva de material superficial sob carga normal e movimento relativo, o que geralmente leva à degradação da superfície, perda da função do componente, e em algumas situações à falha catastrófica (SEIREG, 1998).

Como já foi mencionado, o par válvula e sede operam em condições muito severas. Desgaste e deformações do par tribológico são influenciados principalmente pelas pressões de combustão, temperaturas na área de contato, pelo método de injeção de combustível e taxa de compressão. Para tanto os principais fatores de desgaste do par são mencionados adiante, conforme (BASSHUYSEN e SCHAFER, 2004). 
Carga mecânica na área do assento da válvula: esta carga inclui a carga feita pela mola da válvula, pela força de fechamento da válvula e pela pressão realizada no processo de combustão. Na Tabela 1, mostra-se um exemplo da distribuição percentual das cargas em uma sede de válvula de um mecanismo de $\mathrm{OHC}$ (comando de válvulas no cabeçote de cilindros).

Tabela 1 - Distribuição de carga na válvula e sede de válvula (região de contato).

\begin{tabular}{l|l} 
& Divisão de carga \\
\hline Pré-carga da mola da válvula & $1 \%$ até $3 \%$ \\
\hline Força de fechamento & $2 \%$ até $17 \%$ \\
\hline Pressão de combustão & 80 até $97 \%$ \\
Fonte: BASSHUYSEN e SCHAFER, 2004. &
\end{tabular}

Dependendo do ângulo da sede de válvula utilizada, a carga está dividida em uma componente normal e uma componente paralela à superfície da sede da válvula (vide Figura 4). A componente paralela é o principal responsável pelo desgaste e deformação da sede da válvula. A intensidade das cargas e a distribuição da tensão dependem do tipo de motor e das condições de funcionamento.

Cargas dinâmicas exercidas sobre a sede da válvula devido ao movimento relativo da válvula com a sede de válvula: este é um movimento de rotação da válvula, que depende da velocidade de rotação do motor. Por atuação de válvula, esta velocidade pode variar de $10 \mathrm{rpm}$ até $45 \mathrm{rpm}$. Este movimento é desejado, porque garante tanto a distribuição de temperatura uniforme na válvula e o efeito de limpeza sobre a sede da válvula. Outra carga dinâmica que ocorre na válvula é a deflexão da cabeça da válvula, que acontece automaticamente durante a pressurização da câmara no processo de combustão. Este efeito ocorre devido à diferença de $0,5-1^{\circ}$ no ângulo da sede de válvula e da válvula (Figura 4). Isso permite uma pequena superfície de vedação, que aumenta a pressão na superfície, resultando num efeito de vedação melhor a pressões de combustão mais baixas. Quando a pressão de combustão aumenta, a área de contato aumenta, devido à deflexão da cabeça da válvula.

Lubrificação: a taxa de desgaste no sistema tribológico formada pela válvula e sede de válvula é muito influenciada pela lubrificação entre o par. 
Dependendo da composição da mistura do combustível, o efeito de gases no escape e de admissão pode variar significativamente. Na Tabela 2, compara-se a influência dos tipos de combustíveis e desgaste entre a válvula e a sede de válvula. Em adição a estes efeitos, óleos lubrificantes podem atingir a área de contato na sede da válvula, através da vedação da haste da válvula. Taxas de derramamento de óleo de $0,007-0,1 \mathrm{~cm}^{3} / 10 \mathrm{~h}$ são considerados valores normais durante a operação.

Tabela 2 - Influência do tipo de combustível na ação de desgaste do par tribológico válvula e sede de válvula. A avaliação da admissão e escape é referente à lubrificação do par válvula e sede de válvula de maneira qualitativa.

\begin{tabular}{|c|c|c|c|c|c|}
\hline Combustível & Taxa de Desgaste & $\begin{array}{l}\text { Avaliação } \\
\text { admissão }\end{array}$ & Admissão & $\begin{array}{l}\text { Avaliação } \\
\text { escape }\end{array}$ & Escape \\
\hline Gasolina & $\begin{array}{l}1 \text { até } 5 \mu \mathrm{m} \text { por } \\
1000 \mathrm{~km}\end{array}$ & ++ & $\begin{array}{l}\text { Lubrificação } \\
\text { líquida }\end{array}$ & + & $\begin{array}{l}\text { Lubrificação } \\
\text { líquida }\end{array}$ \\
\hline Diesel & $\begin{array}{l}1 \text { até } 5 \mu \mathrm{m} \text { por } \\
1000 \mathrm{~km}\end{array}$ & - & $\begin{array}{l}\text { Sem } \\
\text { lubrificação }\end{array}$ & ++ & $\begin{array}{l}\text { Sem } \\
\text { lubrificação }\end{array}$ \\
\hline Álcool & $\begin{array}{l}1 \text { até } 10 \mu \mathrm{m} \text { por } \\
1000 \mathrm{~km}\end{array}$ & $\circ$ & $\begin{array}{l}\text { Lubrificação } \\
\text { líquida }\end{array}$ & $\circ$ & $\begin{array}{l}\text { Lubrificação } \\
\text { líquida }\end{array}$ \\
\hline CNG & $\begin{array}{l}2 \text { até } 50 \mu \mathrm{m} \text { por } \\
1000 \mathrm{~km}\end{array}$ & -- & $\begin{array}{l}\text { Sem } \\
\text { lubrificação }\end{array}$ & -- & $\begin{array}{l}\text { Sem } \\
\text { lubrificação }\end{array}$ \\
\hline$\overline{L P G}$ & $\begin{array}{l}20 \text { até } 70 \mu \mathrm{m} \text { por } \\
1000 \mathrm{~km}\end{array}$ & -- & $\begin{array}{l}\text { Sem } \\
\text { lubrificação }\end{array}$ & $\overline{--}$ & $\begin{array}{l}\text { Sem } \\
\text { lubrificação }\end{array}$ \\
\hline Hidrogênio & $\begin{array}{l}20 \text { até } 70 \mu \mathrm{m} \text { por } \\
1000 \mathrm{~km}\end{array}$ & - & $\begin{array}{l}\text { Sem } \\
\text { lubrificação }\end{array}$ & -- & $\begin{array}{l}\text { Sem } \\
\text { lubrificação }\end{array}$ \\
\hline
\end{tabular}

Avaliação: + + Muito Bom, + Bom, ${ }^{\circ}$ Médio, - Pobre, - - Muito Pobre.

Fonte: BASSHUYSEN e SCHAFER, 2004.

Par tribológico em desgaste, a válvula: O projeto do trem de válvula deve considerar uma dureza superior da área de contato na válvula em comparação com as sedes de válvula. Desta forma, a proporção de 3 para 1 de desgaste na válvula e de 2 para 3 na sede da válvula pode ser alcançado. No caso oposto, o desgaste enfraqueceria a cabeça da válvula, gradualmente, causando até falha catastrófica (perda de função) do motor, por consequência.

Valores de dureza típicos encontram-se resumidos na Tabela 3. Em contraste com os materiais utilizados para as sedes de válvula, os materiais para as válvulas foram padronizados e podem ser encontrados nas normas. A combinação ótima de materiais deve ser necessariamente coincidente com a aplicação. 
Tabela 3 - Comparação de dureza típicas para válvulas e sede de válvulas.

\begin{tabular}{l|l|l} 
Componente & Válvula & Sede de Válvula \\
\hline Admissão & $\begin{array}{l}270-370 \text { HBW 2,5/187,5 } \\
\text { Dureza maior que 48HRC }\end{array}$ & $220-320 \mathrm{HBW} 2,5 / 187,5$ \\
\hline Escape & $30-50 \mathrm{HRC}$ & $32-46 \mathrm{HRC}$
\end{tabular}

Fonte: BASSHUYSEN e SCHAFER, 2004.

Segundo WANG (2007), para a tribologia entre a válvula e a sede de válvula deve-se levar em consideração quanto ao desgaste, os seguintes mecanismos:

- Remoção de metal: é causado por (a) abrasivos no lubrificante, (b) corrosão, (c) rasgamento de pontos superficiais elevados e (d) fadiga, que é comumente chamado de "pitting" ou "spalling" dependendo do nível que ocorra.

- Transferência de metal entre as superfícies, comumente chamado de adesão: é devido a uma aderência localizada entre o contato sólido das duas superfícies (válvula e sede de válvula), levando à transferência de material entre as superfícies ou perda de material de qualquer uma das superfícies.

- Deslocamento de material por fluxo plástico, desgaste superficial ou manchas: desgaste observado é uma deformação plástica também conhecido como desgaste sob tensão de cisalhamento ou fluxo radial, que envolve uma deformação plástica da superfície desgastada ao logo da direção de deslizamento devido à alta tensão de contato metal-metal e alto atrito na interface.

Vale salientar que no par tribológico válvula e sede de válvula pode ocorrer as três formas de desgaste simultaneamente.

Conforme descrito na Tabela 2 os níveis de desgaste do sistema tribológico formado pela válvula e sede para motores ciclo diesel estão entre 1 e $5 \mu \mathrm{m}$ a cada $1000 \mathrm{~km}$ rodados de um veículo. Segundo WANG (2007), pode-se calcular o desgaste do par tribológico válvula e sede, individualmente a partir da equação de Archard (2), sendo que quanto mais duro o material, mais resistente ao desgaste: 


$$
V=k * \frac{S * L}{3 H}
$$

Onde:

$\mathrm{V}=$ Volume desgastado (taxa)

$\mathrm{k}=$ Coeficiente de desgaste

$\mathrm{S}=$ Distância de deslizamento

$\mathrm{L}=$ Carga normal

$\mathrm{H}=$ Dureza

\subsection{Metalurgia do Pó}

Segundo SANTOS (2014), metalurgia do pó é uma tecnologia de processamento na qual as peças são produzidas a partir de pós-metálicos. Tem um grande campo de aplicações para materiais metálicos, sendo possível desenvolver muitos produtos aplicando essa técnica, inclusive sede de válvulas. Estudos mostram que a técnica de metalurgia do pó tem sido reconhecida como um método de fabricação de baixo custo, por proporcionar a fabricação de componentes com forma e dimensões próximas às do produto final (near-net shape), versatilidade na seleção da matéria-prima, possibilidade de tratamentos pós-sinterização e economia de energia e mão de obra WANG (2007). Na Figura 7, mostra-se esquematicamente o processo de obtenção de sedes de válvulas. 
Figura 7 - Processo de obtenção de sedes sinterizadas.

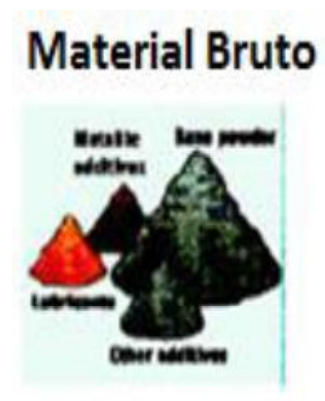

Metal em pó

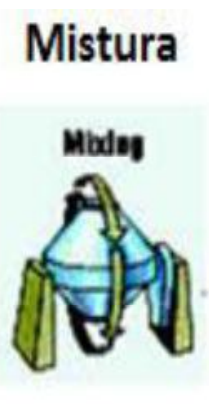

Mistura especial
Compacta

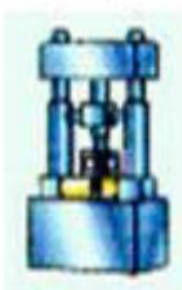

Compactação "green parts"

\section{Sinteriza}

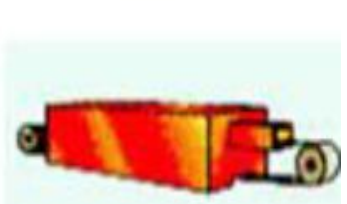

Sinterização conforme procedimento

\section{Calibra}

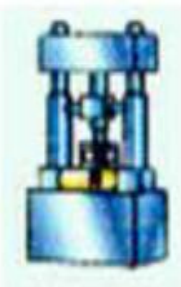

Se necessário

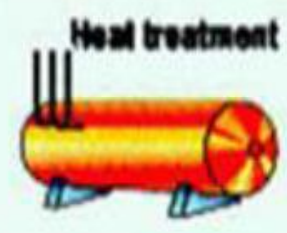

Se necessário

\section{Usinagem}

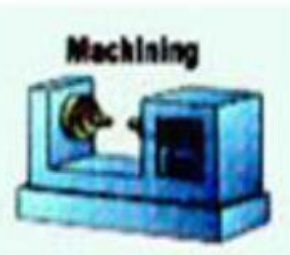

Torneamento

Fonte: Adaptado de Apresentação técnica Bleistahl, 2012.

A European Powder Metallurgy Association realizou um estudo mostrando as vantagens competitivas do uso da metalurgia do pó na confecção de componentes. $\mathrm{Na}$ Figura 8, mostra-se que o uso da metalurgia do pó alia, frente a outras tecnologias de confecção de componentes, melhor eficiência no uso da matéria prima e menor custo energético. 
Figura 8 - Comparação entre diversos tipos de processos de manufatura para confecção componentes.

\begin{tabular}{|c|c|c|}
\hline Uso da Matéria-Prima & Processo de Manufatura & $\begin{array}{l}\text { Consumo de Energia } \\
\text { por } \mathrm{Kg} \text { processado }\end{array}$ \\
\hline 90 & Fundição & $30-38$ \\
\hline 95 & Sinterização & 29 \\
\hline 85 & Extrusão à quente/frio & 41 \\
\hline $75-80$ & Forjamento a quente & $46-49$ \\
\hline $40-50$ & Usinagem & $65-82$ \\
\hline $\begin{array}{lllll}\% & 75 & 50 & 25 & 0 \\
\end{array}$ & & $\begin{array}{lllll}0 & 25 & 50 & 75 & \mathrm{MJ}\end{array}$ \\
\hline
\end{tabular}

Fonte: Adaptado de European Powder Metallurgy Association, 2017.

Segundo BASSHUYSEN e SCHAFER (2004) metalurgia do pó (PM) é uma mistura em pó, que é compactada com uma pressão de até $900 \mathrm{MPa}$ dentro de um molde. As peças em bruto resultantes, os assim chamados corpos verdes em pó (pré-moldes), são sinterizados a temperaturas elevadas $\left(1000^{\circ} \mathrm{C}\right.$ a $1200^{\circ} \mathrm{C}$ para ligas ferrosas) e finalmente submetidas a tratamento térmico. Usinagem mecânica, como torneamento e retífica, conclui o processo de produção. Passos adicionais de fabricação podem ser necessários, dependendo do tipo de material utilizado. $O$ objetivo atual em relação ao desenvolvimento $\mathrm{PM}$ é reduzir o número de passos de fabricação, a fim de alcançar economia na produção. Os materiais da metalurgia do pó utilizados para confecção de sedes de válvulas são subdivididos em vários grupos:

Aços de baixa liga: são usados principalmente para o consumo em motores ciclo Otto. Estes materiais baseiam-se em um sistema Fe-Cu-C. Normalmente é uma estrutura de ferrita e perlita com pequenas quantidades de cementita. A resistência ao desgaste é melhorada pela adição de níquel e molibdénio. A usinabilidade é muitas vezes reforçada pela adição de lubrificantes sólidos, tais como $\mathrm{MnS}, \mathrm{Pb}, \mathrm{MoS}_{2}$, grafite ou $\mathrm{CaF}_{2}$. A quantidade de elementos de liga é inferior a $5 \%$. 
Aços média-liga: geralmente estes materiais são usados nas sedes de escape para motores ciclo Otto, e para sedes de admissão, como também para escape de motores ciclo diesel. Este grupo de materiais é maior e fornece uma ampla gama de variantes. Na sequência as três ligas mais comuns são descritas:

- Aço martensítico: a microestrutura é essencialmente martensitica com carbonetos bem distribuídos, lubrificantes sólidos e, por vezes, outras fases de metal duro. Estas fases de metal duro são fases intermetálicas com alta resistência à temperatura, tais como CoMo-Cr-Si e fases de Co-Cr-W-C.

- Aço rápido (HSS): derivam sua maior resistência ao desgaste de uma matriz martensítica com uma fina distribuição de carbonetos ( $\mathrm{M}_{6} \mathrm{C}$ ou $\mathrm{MC}$ ) que é conseguido por elementos de liga, tais como $\mathrm{Cr}, \mathrm{W}, \mathrm{V}, \mathrm{Mo}$ e, ou Si. Os materiais para confecção de sedes de válvula são baseados em composições de aço rápido padrão (por exemplo, M2, M4 e M35), que foram submetidos a modificações técnicas, como a diluição do pó de ferro ou adição de lubrificantes sólidos.

- Aços bainíticos: em contraste com os outros dois grupos apresentados de materiais, os aços bainíticos não têm nenhuma estrutura temperada, mas sim uma estrutura básica bainítica termicamente mais estável. A adição de lubrificantes sólidos, elementos formadores de carboneto de fases duras, produz boa resistência ao desgaste a temperaturas elevadas. Elementos de liga típicos incluem Co, Ni e Mo.

Todos os grupos de aços média-liga também estão disponíveis com infiltração de cobre. Neste caso, os poros abertos da microestrutura são preenchidos com cobre líquido durante o processo de sinterização. Esta liga apresenta melhor condutividade térmica e usinabilidade.

Aços de alta liga: este grupo inclui os aços martensíticos e austeníticos. Eles são utilizados em motores com maiores exigências com relação a resistência à oxidação em alta temperatura e à corrosão. Elementos de liga típicos incluem $\mathrm{Ni}, \mathrm{Cr}$ e Co, que apresentam custos elevados. Este material é aplicado normalmente em sedes de válvulas que usam tecnologia de dupla camada, no qual a sede de válvula é feita de duas camadas de materiais distintos, sendo um material de alta liga na 
sede da válvula na região que fica em contato com a válvula e um material de baixa liga no restante da peça.

Ligas não ferrosas: em contraste com as ligas de aço, as ligas de $\mathrm{Ni}$ e Co são incomuns no domínio da metalurgia do pó. Ligas de cobre são de especial interesse para os motores de alto desempenho. Um dos objetivos da moderna ciência dos materiais é a substituição do elemento de berílio tóxico nas ligas. A adição de partículas cerâmicas, tais como $\mathrm{Al}_{2} \mathrm{O}_{3}$, já resultou em materiais resistentes ao desgaste. 


\section{MATERIAIS E MÉTODOS}

\subsection{Materiais e dimensões}

Para a execução das atividades foram utilizadas válvula de admissão e sede de válvula conforme recebido, com as seguintes características:

\subsubsection{Válvula}

- Material: Aço DIN EN 10090:1998 - X85CrMoV18-2

- Resistência a tração: 1050 N/mm²

- Módulo de elasticidade: $200000 \mathrm{MPa}$

- Dureza: 45 HRC

Na Figura 9, mostram-se as principais dimensões da válvula.

Figura 9 - Dimensões principais da válvula de admissão.

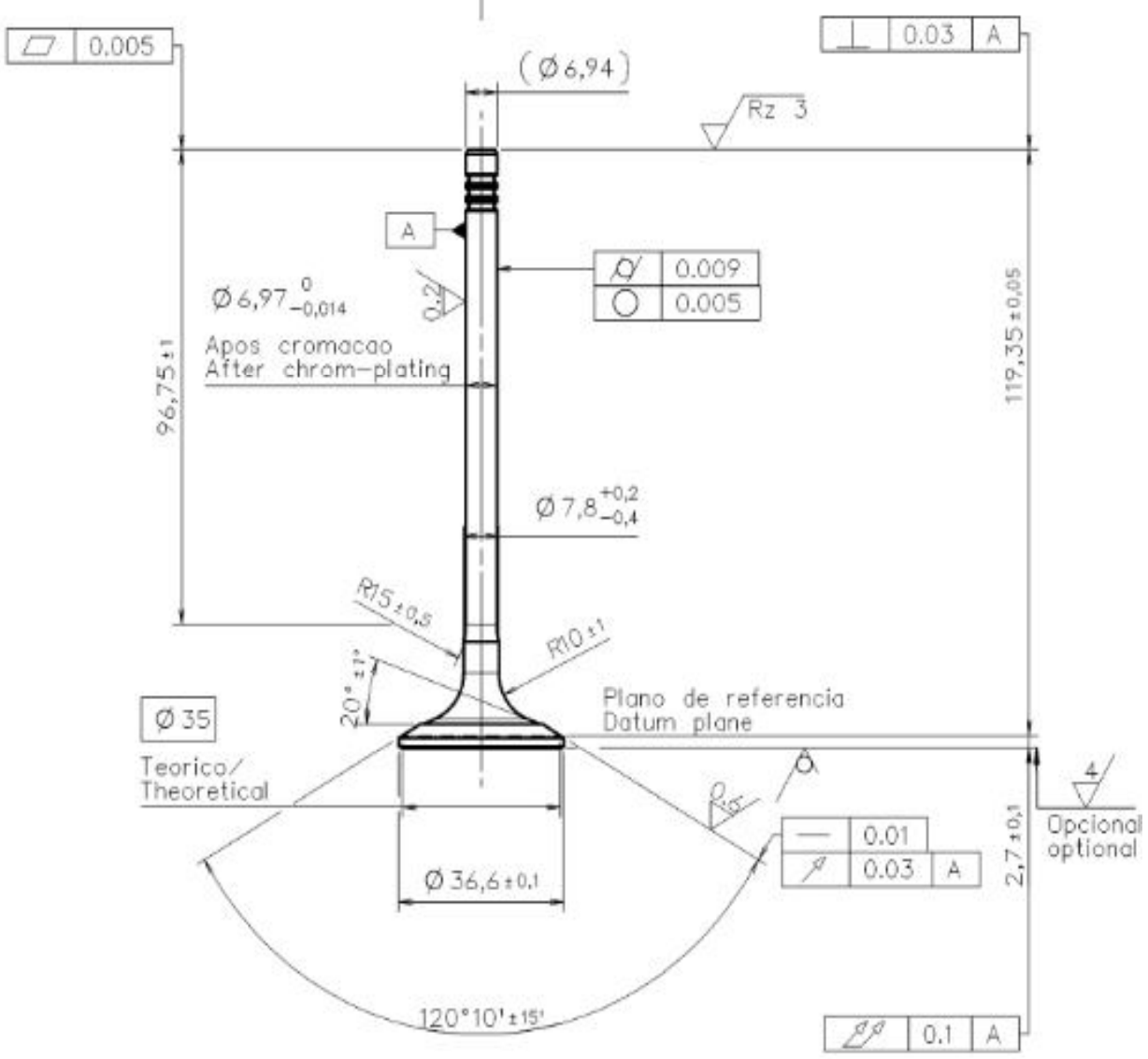

Fonte: autor da dissertação. 


\subsubsection{Sede de Válvula}

Na Tabela 4, mostra-se a composição química nominal (\% em peso).

Tabela 4 - Composição química da sede de válvula (\% em peso).

\begin{tabular}{|c|c|c|c|c|c|c|c|c|c|c|c|c|}
\hline ELEM. & $\mathbf{C}$ & Co & Mo & $\mathbf{W}$ & $\mathbf{V}$ & $\mathbf{C r}$ & $\mathbf{S i}$ & $\mathbf{M n}$ & $\mathbf{S}$ & $\mathbf{C u}$ & $\mathrm{Fe}$ & $\begin{array}{c}\text { Outros } \\
\text { elementos }\end{array}$ \\
\hline Mínimo & 0,80 & 15,0 & 9,0 & 2,5 & 1,3 & 3,5 & 0,5 & 0,3 & 0,15 & 10,0 & $\begin{array}{c}\mathrm{R} \\
\mathrm{E} \\
\mathrm{S}\end{array}$ & \\
\hline Máximo & 1,30 & 22,0 & 14,0 & 4,5 & 2,3 & 5,5 & 2,0 & 1,5 & 0,75 & 20,0 & $\begin{array}{c}\mathrm{A} \\
\mathrm{N} \\
\mathrm{T} \\
\mathrm{E}\end{array}$ & $<3,0$ \\
\hline
\end{tabular}

Fonte: autor da dissertação.

A sede de válvula é um aço rápido sinterizado, com microestrutura que consiste em carbonetos finos distribuídos e fases intermetálicas uniformemente disperso numa matriz martensítica revenida. Lubrificantes sólidos são uniformemente distribuídos e os poros preenchidos com cobre. Na Figura 10, mostra-se a microestrutura da sede de válvula. A sede de válvula tem módulo de elasticidade de 150000 MPa e dureza de 45 HRC (mínimo).

Figura 10 - Micrografia em microscópio óptico mostrando a estrutura da matriz - carbonetos distribuídos fina e uniformemente, e uma fase intermetálica em uma matriz martensítica. Ataque: Nital 3\%.

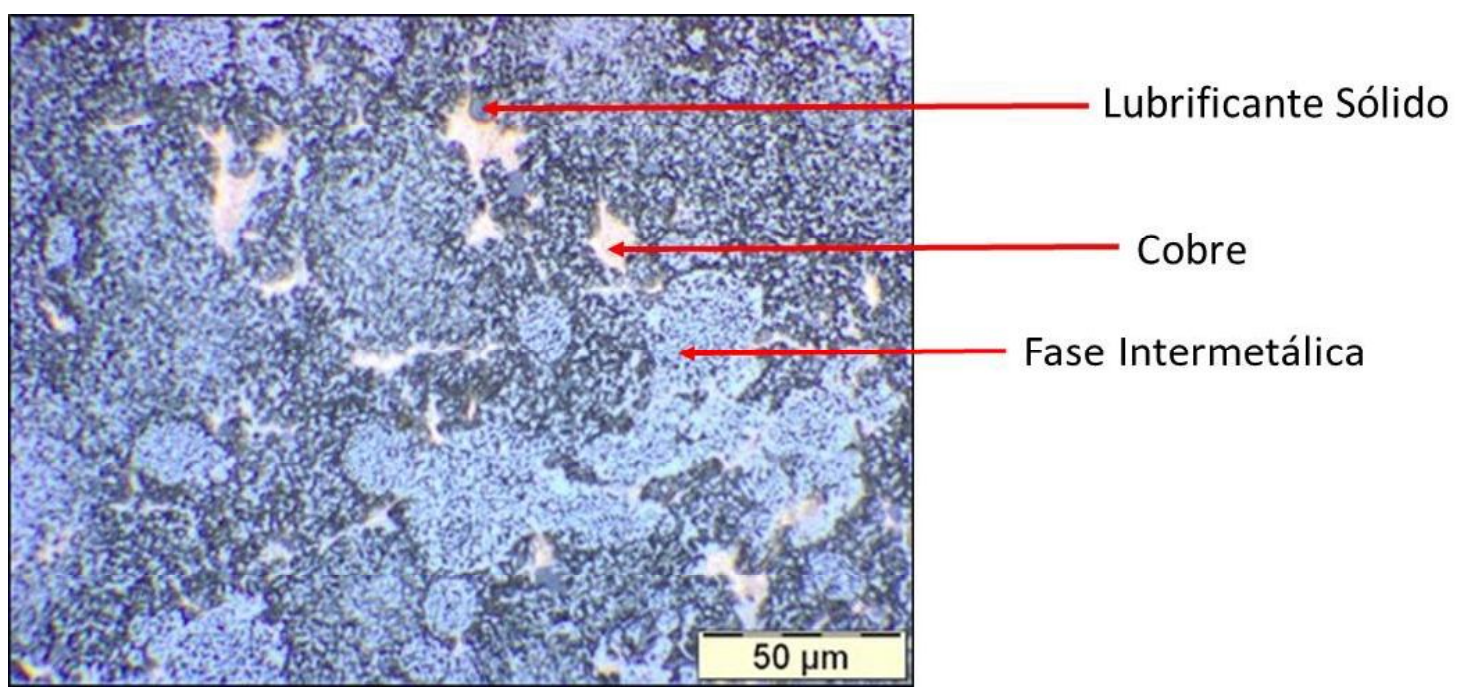

Fonte: autor da dissertação. 
Na Figura 11, ilustram-se as principais dimensões da sede de válvula, já montada no cabeçote do motor. Foi utilizada esta imagem de montagem, pois a sede é usinada após ser montada no cabeçote.

Figura 11 - Dimensões principais da sede de válvula montada no cabeçote. Vale salientar que são duas sedes de válvula de admissão por cabeçote.
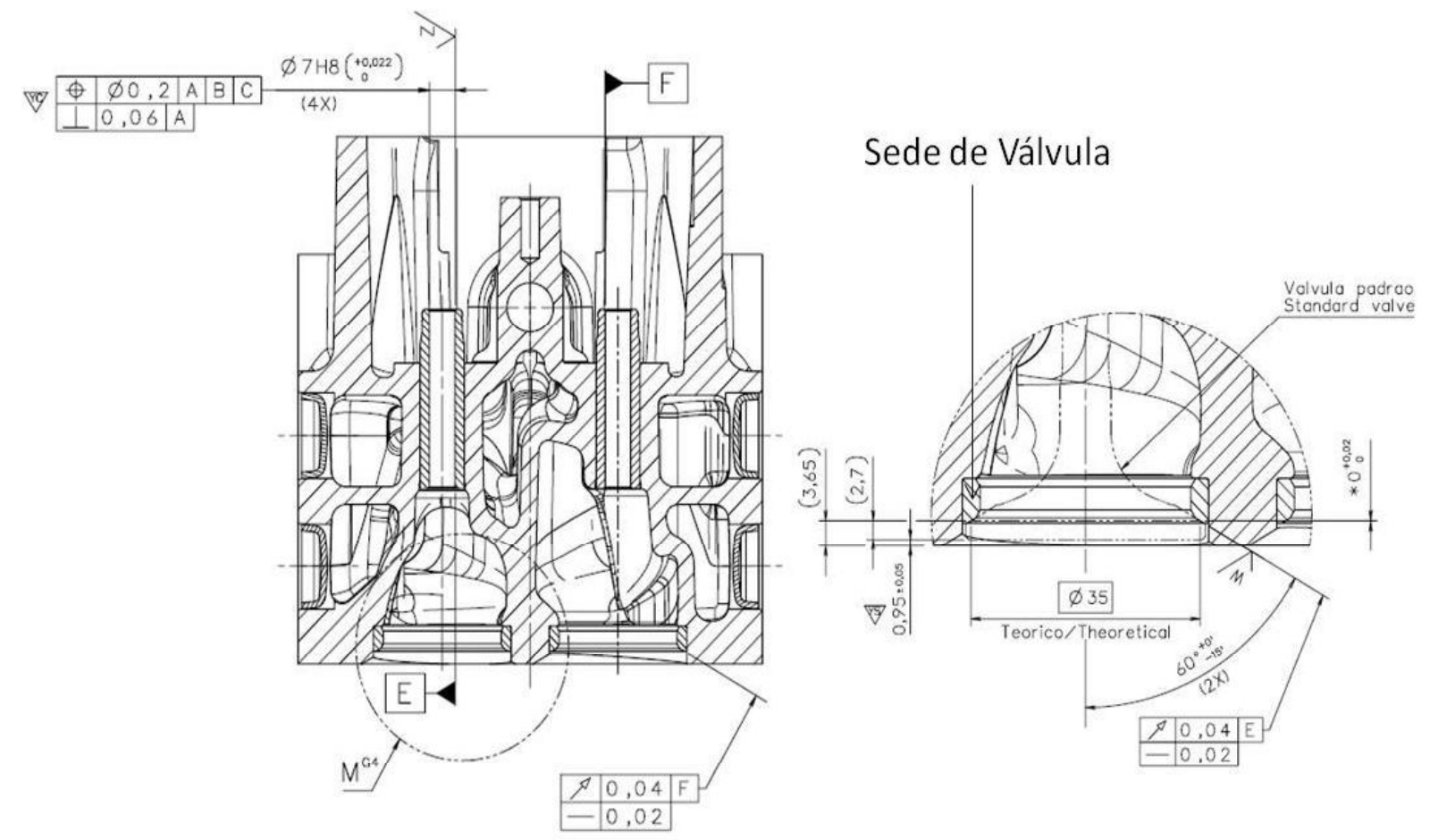

Fonte: autor da dissertação.

\subsection{Métodos}

\subsubsection{Esquema do conjunto}

Conforme mencionado anteriormente, o conjunto válvula e sede de admissão desempenham um importante papel para um bom desempenho do motor. Para tanto, o conjunto deverá apresentar níveis de desgastes aceitáveis, para manter as emissões de poluentes dentro dos limites estipulados em norma, bem como requisitos operacionais de manutenção e vida do produto.

$\mathrm{Na}$ Figura 12, mostra-se o trem de válvulas do motor que foi avaliado. $\mathrm{Na}$ Figura 12 (a), mostram-se os componentes desde o eixo de comando de válvulas, passando pelos tuchos, varetas, parafuso de regulagem, até chegar aos balanceiros 
(de admissão e escape do motor), que estão em contato com as válvulas do motor. $\mathrm{Na}$ Figura 12 (b), mostra-se em detalhe o conjunto que foi estudado, o par de válvulas e sedes de admissão.

Figura 12 - (a) trem de válvulas do motor ciclo diesel utilizado para avaliação (b) detalhe, em corte transversal, do conjunto que foi avaliado.

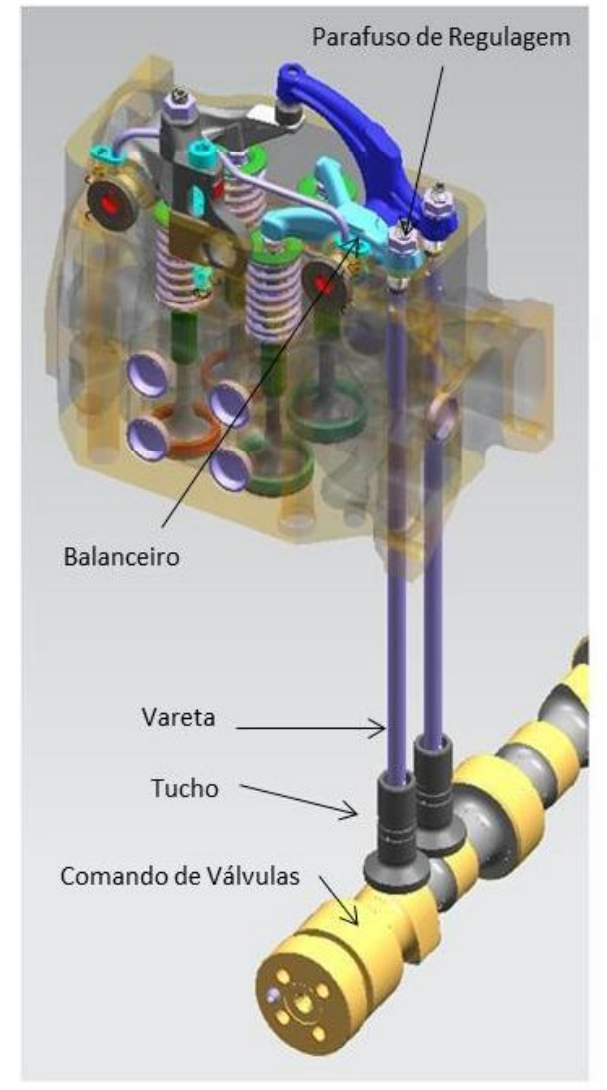

a

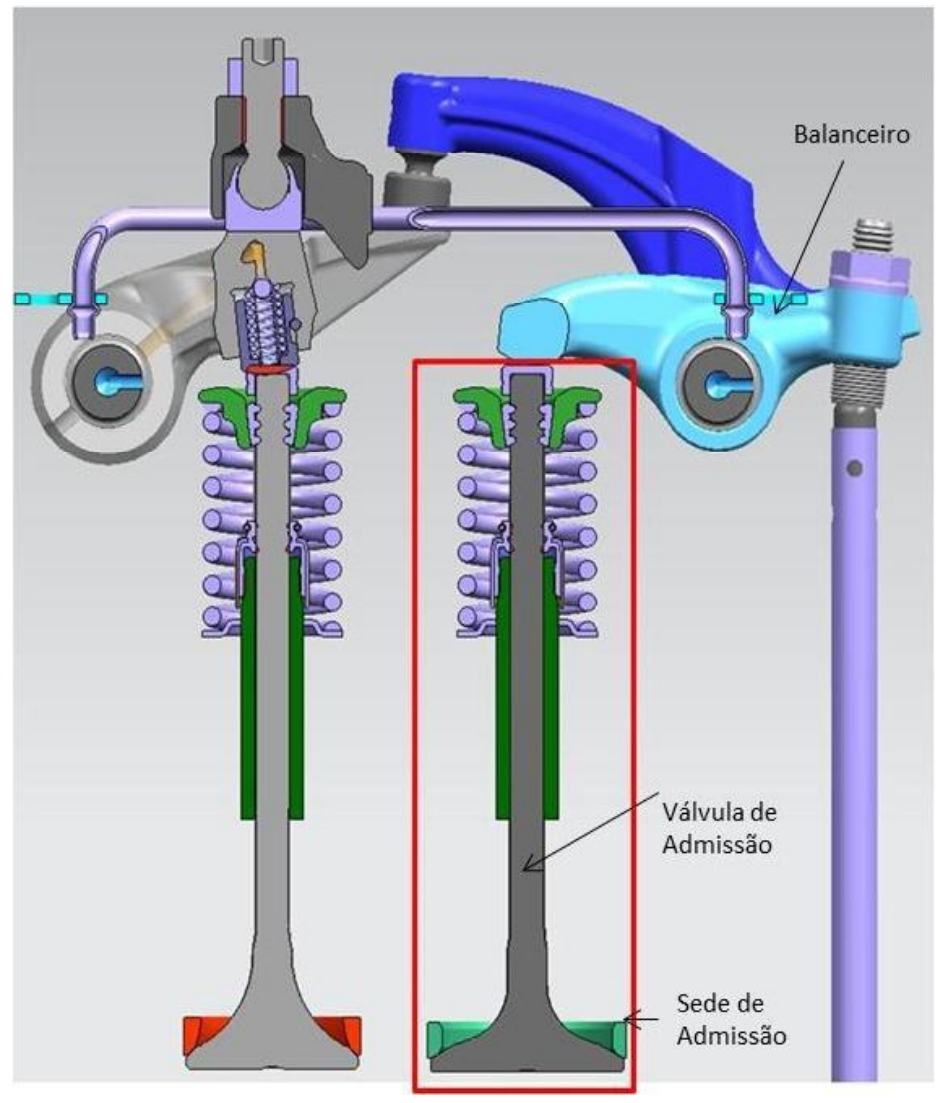

b

Fonte: autor da dissertação.

O par tribológico válvula e sede apresenta diversos mecanismos de desgaste, conforme visto anteriormente, que são influenciados principalmente pelas pressões de combustão, temperaturas na área de contato, pelo método de injeção de combustível e taxa de compressão. Na Figura 13, mostra-se em detalhe a região em que foram concentrados os estudos, de maneira a identificar o mecanismo de desgaste. 
Figura 13 - Região de desgaste é onde ocorre o contato entre a válvula e a sede de válvula. Objeto de estudo evidenciado neste trabalho.

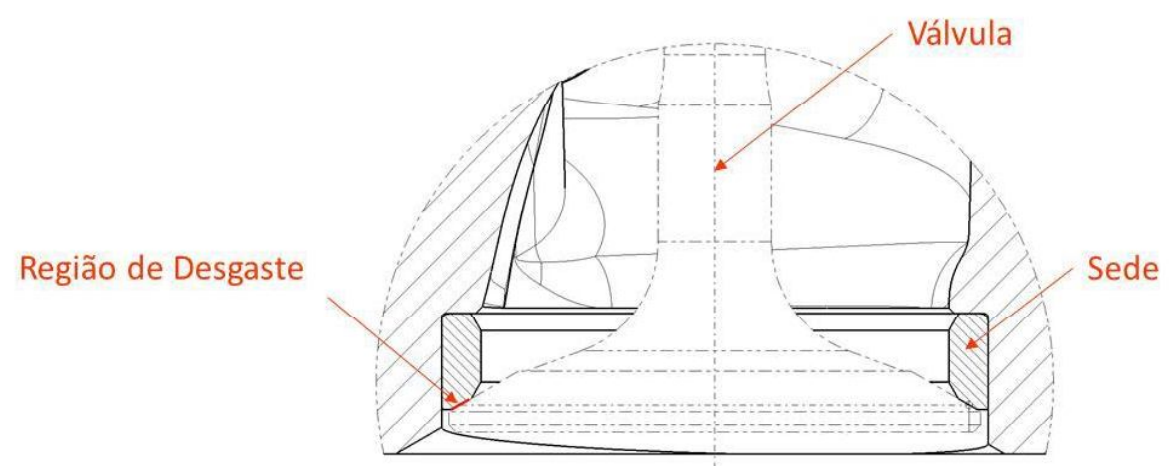

Fonte: autor da dissertação.

Pode-se correlacionar uma série de fatores que influenciam no estudo tribológico da válvula e sede de válvula diante do mencionado em literatura, conforme descrito nos itens 3.4 e 3.5 deste trabalho. Com isso podemos definir os fatores de preocupação relacionados ao desgaste do conjunto válvula e sede de válvula. A Figura 14, traz os fatores que são relevantes para o estudo de desgaste do par tribológico válvula e sede de válvula de admissão.

Figura 14 - Parâmetros tribológicos relacionados ao par válvula e sede de válvula de admissão.

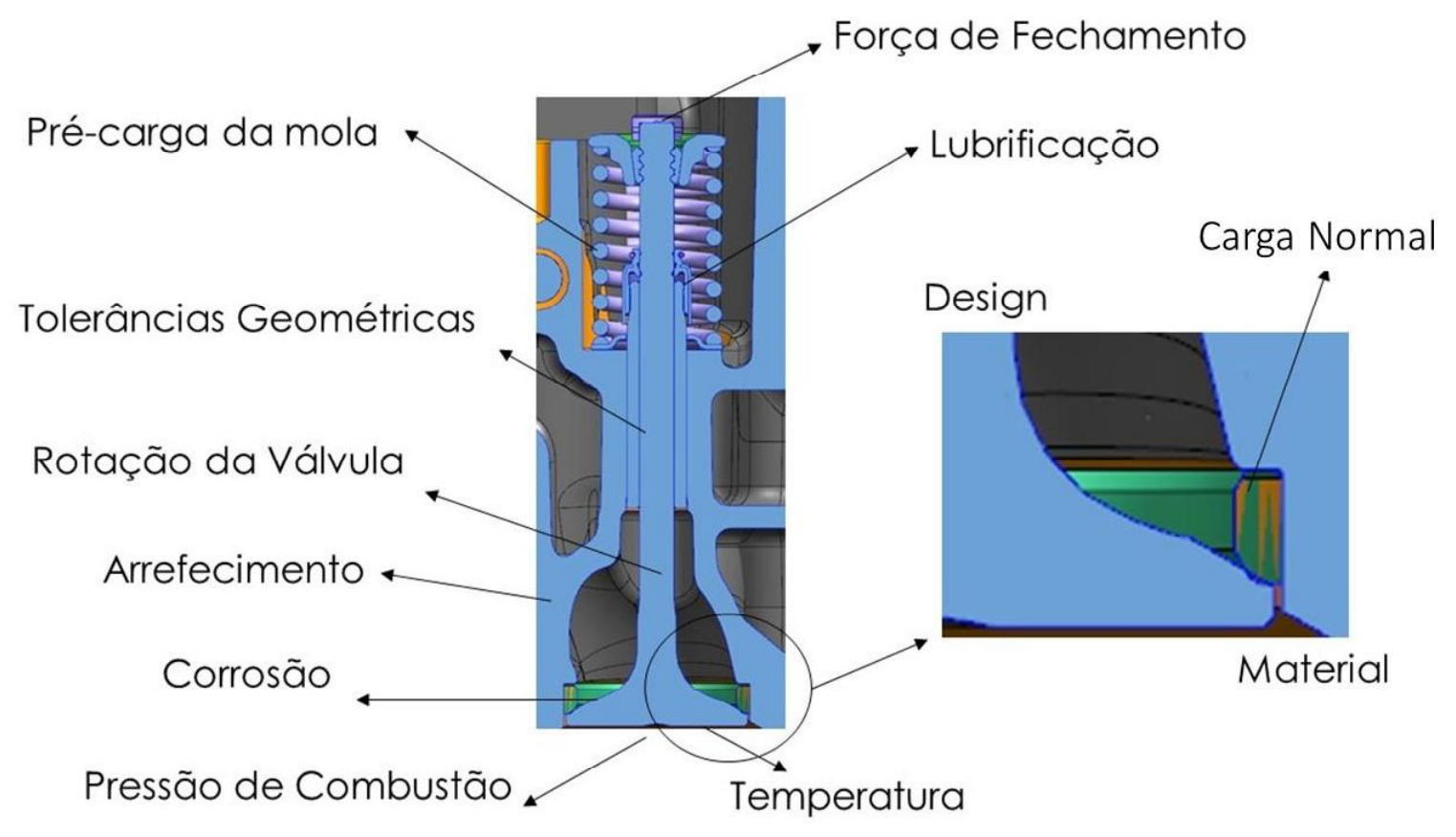

Fonte: autor da dissertação. 


\subsubsection{Equipamentos de testes}

Para execução dos ensaios foram utilizados motores com as seguintes características:

- Motor: diesel turbo com arrefecimento do ar de admissão.

- Cilindrada total: 7,2 litros.

- Potência: $330 \mathrm{cv}$ na rotação de 2200 rpm.

- Pressão de Combustão: 180 bar na condição de 2200 rpm em plena carga do motor.

- Torque Nominal: $1300 \mathrm{Nm}$ (132.5 m.kgf) de $1200 \mathrm{rpm}$ até1600 rpm

- Nível de Emissões atendendo: PROCONVE P7/Euro V

Na Figura 15, mostra-se uma imagem em três dimensões do motor ciclo diesel que foi utilizado durante os ensaios. Foram utilizados dois motores, sendo um para os ensaios em dinamômetro e outro para os ensaios veiculares. Vide item 4.2.4 para compreensão das atividades.

Figura 15 - Motor diesel que foi utilizado durante os ensaios. Imagem em três dimensões.

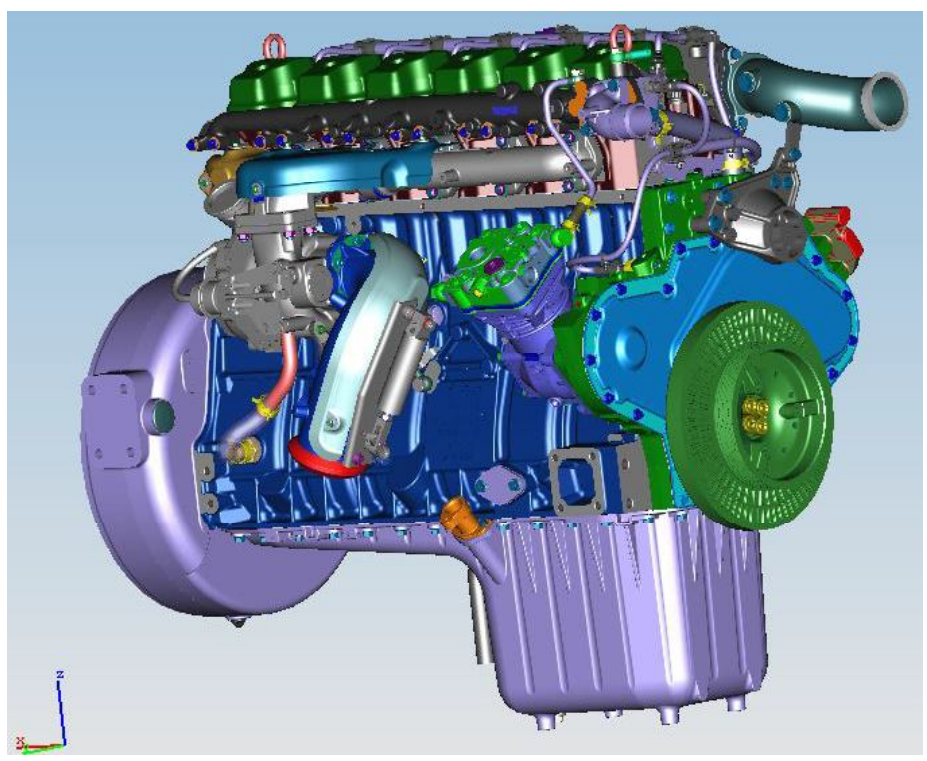

Fonte: autor da dissertação.

Para os ensaios em dinamômetro foram utilizados os bancos de testes da MWM Motores diesel, que são equipados com dinamômetros modelo W400 da Schenck, além de toda instrumentação e aquisição de dados de controle e 
desempenho do motor, tais como: temperaturas e pressões de trabalho. Na Figura 16, mostra-se a instalação do motor em um banco de testes.

Figura 16 - Banco de testes equipado com dinamômetro utilizado para as avaliações das válvulas e sede de válvulas de admissão.

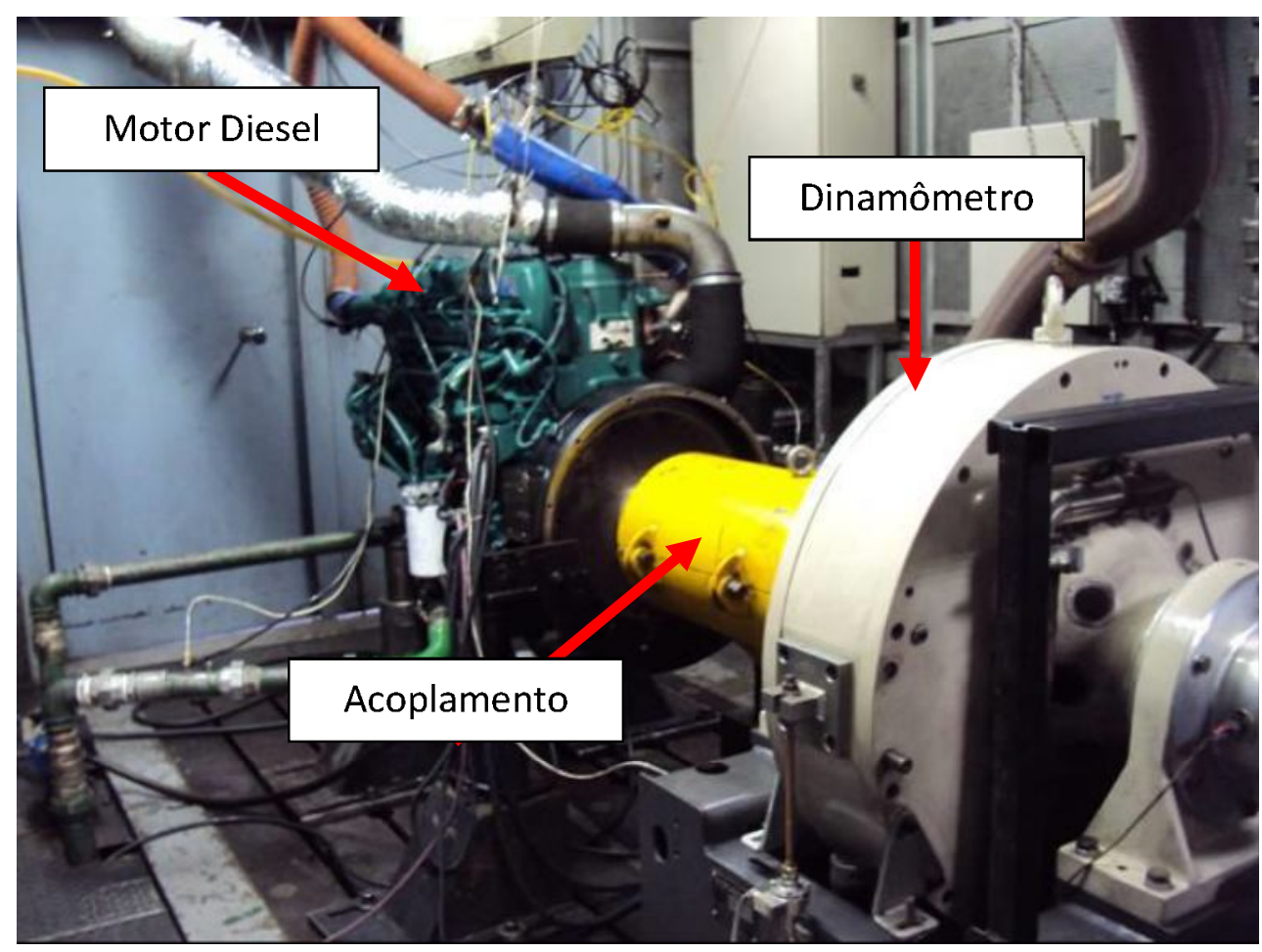

Fonte: autor da dissertação.

4.2.3 Equipamentos para avaliações dimensionais e metalúrgicas

Para caracterização dimensional das sedes e válvulas (ângulo de assentamento e batimento entre sede e guia e batimento entre a cabeça da válvula e haste da válvula) foi utilizada mesa tridimensional Zeiss modelo Vast. Para medição de profundidade de válvula foi utilizado relógio comparador Sylvac. As Figuras 18 (a) e 18 (b), mostram os equipamentos utilizados para as medições dimensionais das características da sede de válvula.

Dentro da metrologia, o uso do relógio comparador é uma das tarefas mais fáceis. Conforme SENAI - ES (1996), trata-se de um instrumento de precisão de grande sensibilidade. É utilizado tanto na verificação de medidas, superfícies planas, concentricidade e paralelismo, como para leituras diretas. 
Por sua elevada precisão e versatilidade, o relógio pode ser usado medindo ou comparando diversas formas de peças. Na Figura 17, mostra-se um modelo padrão de relógio comparador analógico.

Figura 17 - Modelo padrão de um relógio comparador.

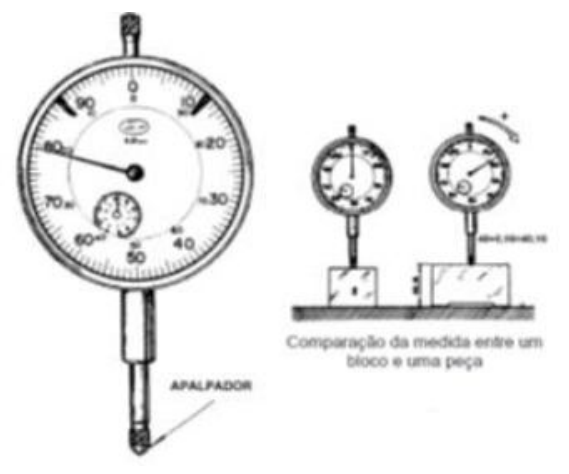

Fonte: SENAI - ES, 1996.

Conforme SENAI - ES (1996), o princípio de funcionamento consiste em uma ponta apalpadora que fica em contato com a peça. A diferença de medida da peça provoca um deslocamento retilíneo da ponta, transmitido por um sistema de amplificação ao ponteiro do relógio. A posição do ponteiro no mostrador indica a leitura da medida. A precisão do instrumento baseia-se no sistema de amplificação, geralmente usado por meio de engrenagens, alavancas ou sistema misto.

Figura 18 - (a) Medição das sedes e guia de válvulas em mesa tridimensional. (b) Medição da profundidade da válvula com relação à face de fogo do cabeçote com relógio comparador. Este valor indica quanto ocorreu de desgaste do conjunto conhecendo os valores antes e após o teste de avaliação.

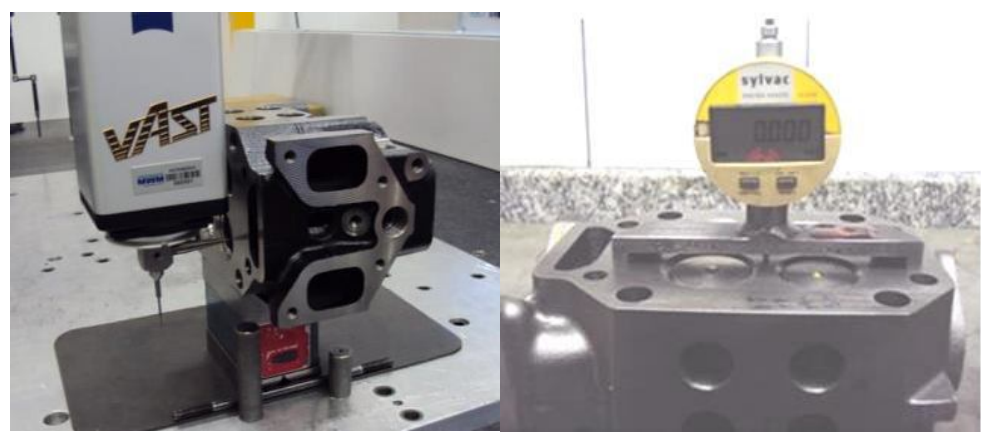

a

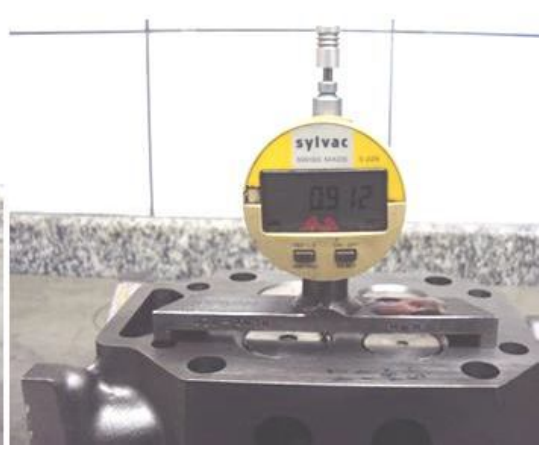

b

Fonte: autor da dissertação. 
Para caraterização metalúrgica antes e após os ensaios foram utilizados os seguintes equipamentos, conforme Tabela 5.

Tabela 5 - Equipamentos utilizados para análise metalúrgica das válvulas e sedes de válvula.

\begin{tabular}{|c|c|}
\hline Análise & Equipamento \\
\hline Análise da microestrutura & $\begin{array}{l}\text { Equipamento: Microscópio Ótico. } \\
\text { Fabricante: Reichter-Young. } \\
\text { Modelo: Polyvar. }\end{array}$ \\
\hline Análise macroestrutural & $\begin{array}{l}\text { Equipamento: Lupa Estereoscópica } \\
\text { Fabricante: Olympus } \\
\text { Modelo: SZ61 }\end{array}$ \\
\hline Ensaios Físicos & $\begin{array}{l}\text { Equipamento: Durômetro HRC. } \\
\text { Fabricante: Importécnica. } \\
\text { Modelo: GNEHM } 160 \text { Digito. }\end{array}$ \\
\hline Análise Química & $\begin{array}{l}\text { Equipamento: Espectrômetro de } \\
\text { Emissão Óptica } \\
\text { Fabricante: SPECTRO } \\
\text { Modelo: Spectromax }\end{array}$ \\
\hline $\begin{array}{l}\text { Análise topográfica e espectrometria por } \\
\text { dispersão de energia (EDS) }\end{array}$ & $\begin{array}{l}\text { Equipamento: Microscópio Eletrônico de } \\
\text { Varredura. } \\
\text { Fabricante: FEl } \\
\text { Modelo: Quanta } 450\end{array}$ \\
\hline
\end{tabular}

Fonte: autor da dissertação.

As principais análises metalúrgicas realizadas neste trabalho foram conduzidas utilizando-se recursos de microscopia ótica e eletrônica, que são técnicas de caracterização por métodos físicos complementares. Segundo MONTEIRO e BUSO (2004) fundamentalmente, microscópios eletrônicos e ópticos 
são idênticos, isto é, ambos servem para aumentar pequenos objetos, normalmente invisíveis a olho nu, com a respectiva formação de uma imagem aumentada e visível a olho nu. A diferença básica entre os dois, entretanto, é que o microscópio eletrônico utiliza um feixe eletrônico (que tem o comportamento de uma onda eletromagnética) enquanto que o microscópio óptico utiliza um feixe de ondas eletromagnéticas de comprimento de onda visível aos nossos olhos que é a luz, podemos, neste segundo caso, incluir também o raio ultravioleta e "LASER".

Nas Figuras 19 (a) e (b), mostram-se os principais equipamentos utilizados para análise de microestrutura (microscópio óptico) e análise de desgaste (microscópio eletrônico de varredura).

Figura 19 - (a) Microscópio ótico utilizado para análise de microestrutura. (b) Microscópio eletrônico de varredura utilizado para análise de desgaste. Foto tiradas nas instalações da MWM Motores diesel (MWM, 2016).

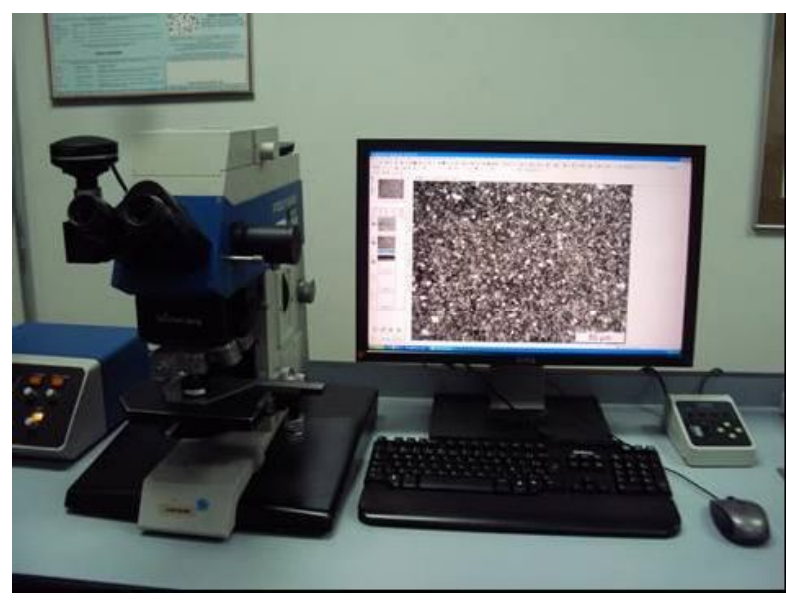

a

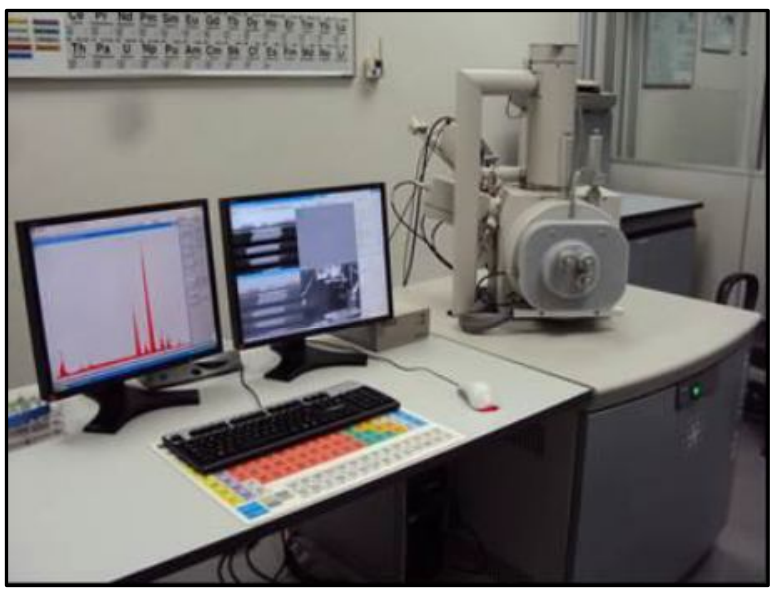

b

Fonte: autor da dissertação.

\subsubsection{Atividades}

As atividades foram planejadas conforme o seguinte fluxo, ilustrado na Figura 20. 
Figura 20 - Sequência de atividades conduzidas para a evolução deste trabalho.

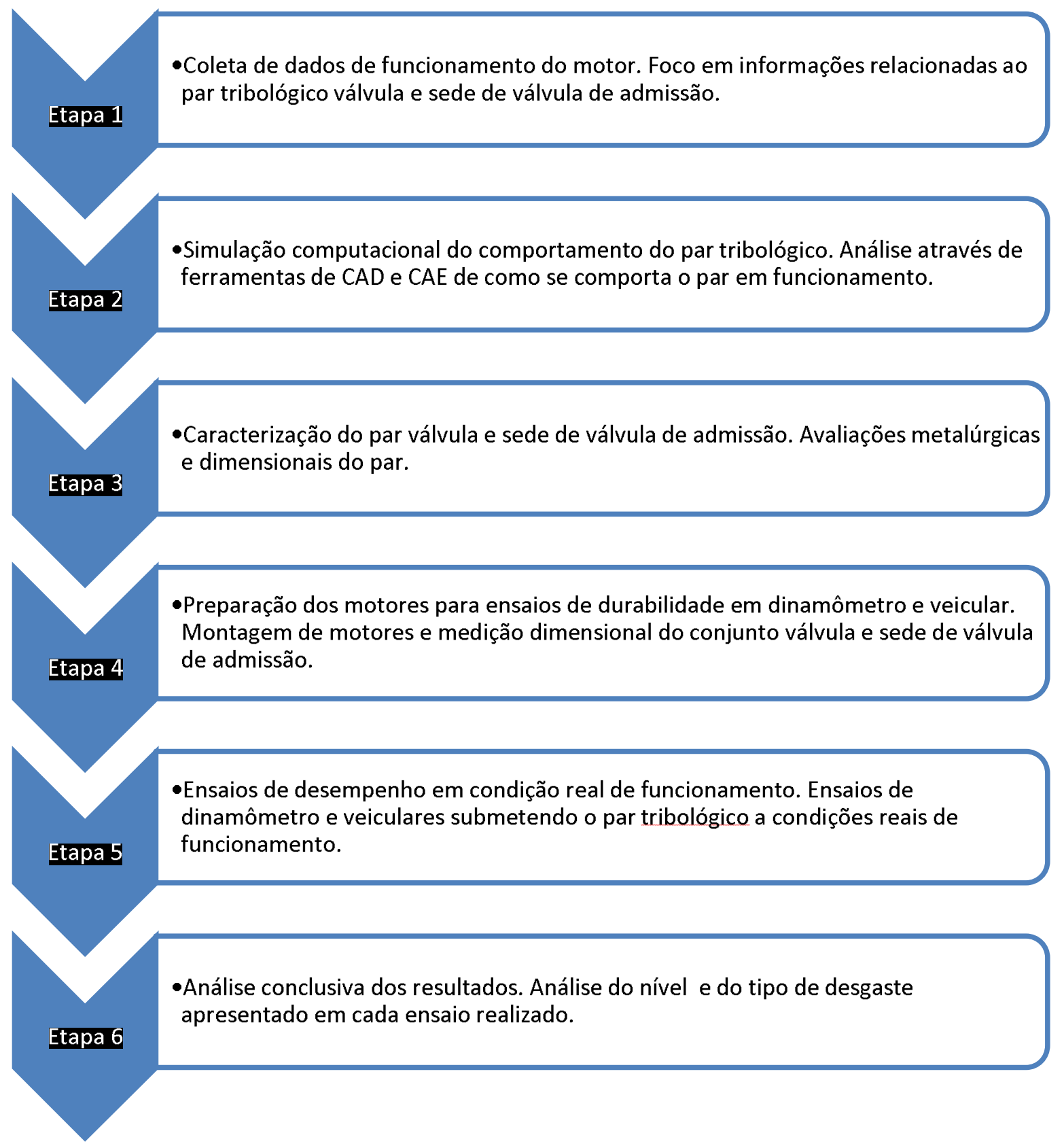

Fonte: autor da dissertação.

Para a etapa 1 foi montado um motor conforme descrito no item 4.2.2 utilizando o par tribológico relacionado ao estudo deste trabalho e foram coletadas informações relacionadas ao funcionamento do motor. Os itens coletados foram: desempenho do motor em plena carga em termos de potência, torque e consumo de combustível especifico em função da rotação do motor, ensaios de emissões de poluentes conforme descrição da Resolução CONAMA 403/2008, sendo que para estes ensaios foram adotados o ciclo de emissões denominado E.S.C. (Ciclo 
Europeu em Regime Constante), que consiste de um ciclo de ensaio com 13 modos de operação em regime constante, sempre comparando com os limites de emissões conforme PROCONVE fase P7. Ainda, foram coletadas nesta etapa do planejamento informações relacionadas a pressão de combustão do motor em regime de operação à plena carga em diversos pontos de rotação do motor, como também em função da rotação do eixo virabrequim no regime de operação de potência do motor (2200rpm). Por fim foram montadas válvulas de admissão sensitivas para verificação de temperatura de operação deste componente em ciclo especifico, que adiante será descrito, sendo que esta informação foi utilizada para análise do limite operacional da válvula com relação a temperatura de trabalho. Os procedimentos de ensaios de durabilidade estão descritos no item 4.2.5.

Durante a etapa 2 utilizou-se de análises em CAD (computer aided design) e CAE (computer aided engineering), através do software CATIA V5 para analisar o comportamento do par tribológico válvula e sede de válvula de admissão quando ao deslocamento relativo entre os corpos. Como o par em estudo trata-se de componentes internos e visualizar o funcionamento deste conjunto em regime de trabalho real apresenta uma série de dificuldades, a ferramenta simulou a movimentação do conjunto enquanto estivessem em contato, para tanto foram utilizadas as dimensões nominais do conjunto válvula e sede de válvula e módulo de elasticidade conforme mencionadas no item 4.1.1 e 4.1.2.

Para a simulação foi considerado o coeficiente de atrito entre válvula e sede de válvula de admissão conforme a Figura 21. A Figura 21, trata-se dos regimes de lubrificação dos diversos sistemas do motor de combustão interna, sendo que para o conjunto válvula e sede de válvula conforme visto no item 3.5 é considerado sem lubrificação direta, ou regime de lubrificação limítrofe. Ainda nesta etapa foram analisadas a pressão de contato entre válvula e sede de válvula através de análises de elementos finitos (FEA), com o auxílio do software de CAE Samcef, considerando características dos materiais, pressão de combustão máxima e condições térmicas, coletadas na etapa 1 , anteriormente descritas. 
Figura 21 - Relação entre os regimes de lubrificação e o atrito dos componentes de um motor de combustão interna (curva de Stribeck adaptada). Verifica-se que o conjunto válvula e sede de válvula de admissão se enquadram em uma condição limite de lubrificação, sendo no gráfico $(\mu)$ a viscosidade absoluta, $(U)$ a velocidade e $(p)$ a carga unitária.

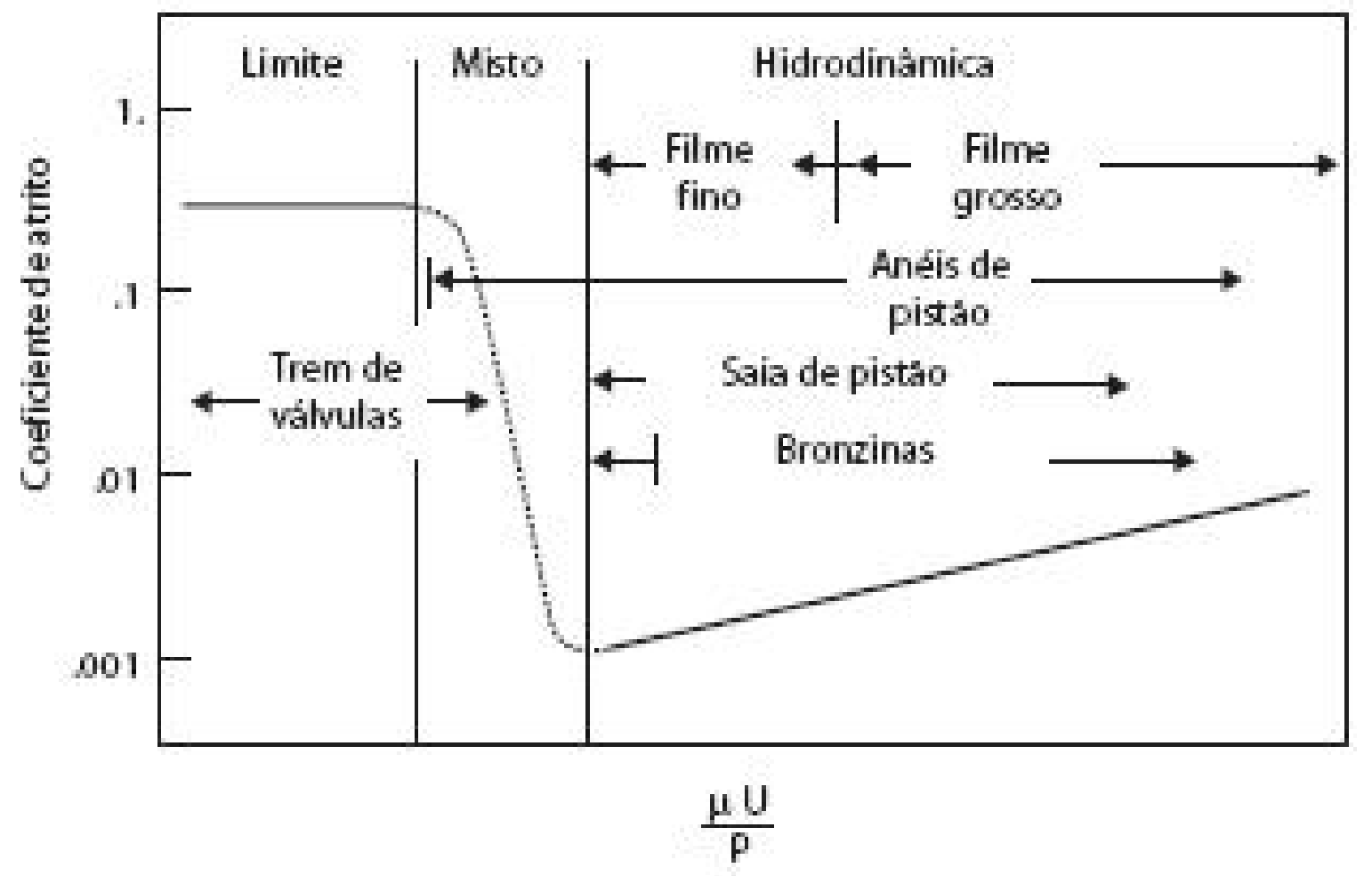

Fonte: Adaptado de (ROSEMBERG, 1982).

A etapa 3 foi destinada para o dimensionamento e caracterização metalúrgica dos componentes. Os dados encontrados foram confrontados com as especificações dos componentes válvula e sede de válvula conforme descritos nos itens 4.1.1 e 4.1.2. As dimensões medidas foram o diâmetro da cabeça de válvula, ângulo da cabeça da válvula, batimento entre a cabeça da válvula e haste de válvula, diâmetro interno na sede de válvula, ângulo do assentamento da sede de válvula e batimento entre guia de válvula e sede de válvula. A caracterização metalúrgica da válvula e da sede de válvula foi realizada de uma peça (válvula e sede de válvula) do mesmo lote.

Durante a etapa 4, complementar à etapa 3, foram montados os dois motores, sendo um motor destinado as atividades de dinamômetro (durabilidade de 2000 horas) e outro para o ensaio veicular (durabilidade de 100000 km). Durante a 
montagem dos motores foram medidas as profundidades de válvulas conforme descrito no item 4.2.3.

$\mathrm{Na}$ etapa 5 foram executados os ensaios de durabilidade em dinamômetro e veicular, conforme item 4.2.5. Após os ensaios de durabilidade em dinamômetro e veicular foram medidas novamente a profundidade de válvulas conforme item 4.2.3, para conhecer o nível de desgaste do par tribológico válvula e sede de válvula de admissão, bem como análises das características metalúrgicas de um conjunto testado e a caracterização do tipo de desgaste apresentado após os testes de durabilidade.

\subsubsection{Ensaios}

Os estudos do comportamento do par tribológico válvula de admissão e sede de válvula para determinação de vida e atendimento a requisitos legais foram executados através dos ensaios de durabilidade em dinamômetro de 2000 horas de duração, que correspondem a $200000 \mathrm{~km}$ percorridos por um veículo e durabilidade veicular durante $100.000 \mathrm{~km}$.

No dinamômetro foram executados basicamente verificações, quanto aos requisitos de desempenho e emissões de poluentes, conforme norma do CONAMA - PROCONVE 7, antes e após o ensaio de durabilidade de 2000 horas de duração total, que de fato avaliou o comportamento do par tribológico quanto ao nível de desgaste ocorrido, bem como o tipo de desgaste. $O$ ensaio de durabilidade veicular teve como foco a avaliação das condições operacionais relacionadas a vida e manutenção do produto. Tanto o ensaio de emissões, quanto os ensaios de durabilidade estão descritos respectivamente nos itens 4.2.5.1 e 4.2.5.2.

\subsubsection{Ensaio de Emissões de Poluentes}

Conforme já mencionado, o ensaio de emissões de poluente foi realizado com o motor novo antes da durabilidade e após a rodagem da durabilidade em dinamômetro, descrito no item 4.2.5.2. O ensaio seguiu as orientações contidas na resolução do CONAMA fase P-7 (Resolução CONAMA 403/2008). O ciclo realizado foi o ciclo ESC - denominado Ciclo Europeu em Regime Constante - consiste de um 
ciclo de ensaio com 13 modos de operação em regime constante. Na Tabela 6, mostra-se os limites de operação para o ciclo ESC.

Tabela 6 - Limites de emissão de poluentes através do ciclo ESC.

\begin{tabular}{l|l|l|l|l} 
Ensaio & \multicolumn{4}{l}{ Poluentes (g/kW.h) } \\
\hline & NOx & HC & CO & Material Particulado \\
\hline Limite (Resolução) & 2,00 & 0,46 & 1,5 & 0,02
\end{tabular}

Fonte: Resolução CONAMA 403/2008.

\subsubsection{Ensaio de Durabilidade em Dinamômetro e Veicular}

O ensaio de durabilidade consistiu em rodar o motor em dinamômetro por 2000 horas, que correspondem a $200.000 \mathrm{~km}$, conforme ciclo descrito na Tabela 7 . A cada 200 horas eram realizadas as manutenções no motor para averiguar entre outros parâmetros, as folgas de válvulas, que são um indicador de como está se comportando o par tribológico durante o ensaio. Vale salientar, que antes do ensaio (durante a montagem do motor) e após o ensaio (durante a desmontagem do motor) foram averiguados os valores de profundidade de válvulas conforme descrito no item 4.2.3.

Tabela 7 - Ciclo de ensaio de durabilidade.

Ensaio de Durabilidade em Dinamômetro

\begin{tabular}{c|c|c|c}
\hline \multicolumn{3}{l|}{ Tempo de teste } & Ciclo \\
\hline \multicolumn{4}{|c}{ horas } \\
\hline Passo & Rotação (rpm) & Carga (\%) & Tempo (min) \\
\hline 1 & 1000 & 30 & 75 \\
\hline 2 & 2200 & 100 & 4 \\
\hline 3 & 1635 & 60 & 25 \\
\hline 4 & 1390 & 100 & 4 \\
\hline 5 & 2550 & 0 & 10 \\
\hline 6 & 2200 & 100 &
\end{tabular}

Fonte: autor da dissertação. 
Os ensaios de durabilidade veicular foram conduzidos até o veículo completar $100.000 \mathrm{~km}$. Os dados de rota e características do veículo são apresentados na Figura 22.

Figura 22 - Condições do de durabilidade veicular.

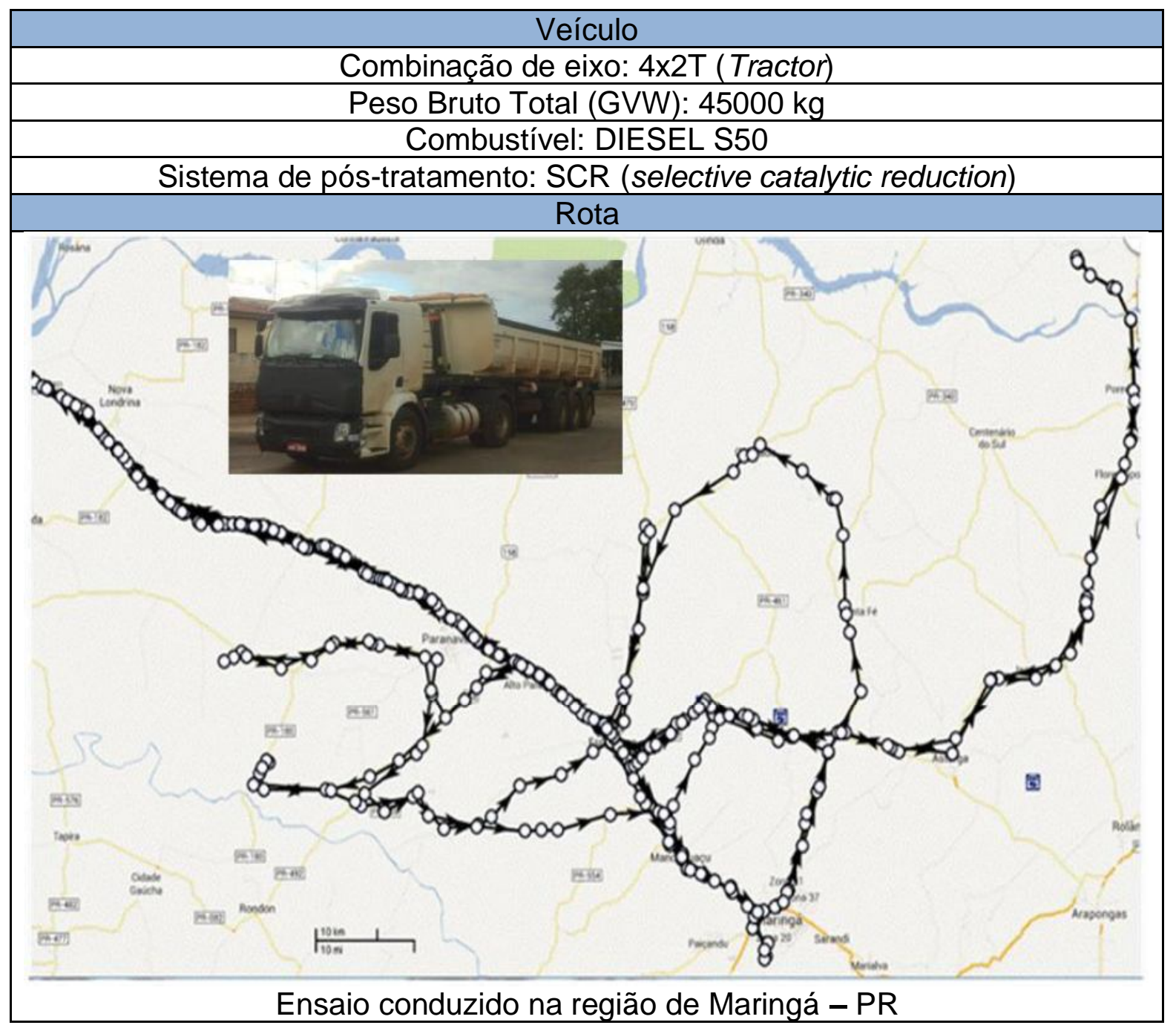

Fonte: autor da dissertação

Em ambos os ensaios de durabilidade conduzidos (dinamômetro e veículo) foram avaliados o nível e o tipo de desgaste apresentado pelo par tribológico válvula e sede de válvula de admissão.

\subsubsection{Requisitos de aprovação}

A aprovação do par tribológico está condicionada aos valores de desgaste comumente estabelecido para motores ciclo diesel (vide Tabela 2) e não ocorrer 
deterioração de valores de desempenho do motor relacionados a emissões de poluentes (PROCONVE P7), valores de potência e consumo de combustível normalizados conforme ISO 1585. 


\section{RESULTADOS}

\subsection{Coleta de dados de funcionamento do motor}

Durante esta etapa (etapa 1) foram coletados os dados de funcionamento do motor para entender as condições de trabalho do par tribológico válvula e sede de admissão. Os dados coletados foram:

1) Curvas de potência, torque e consumo de combustível;

2) Informações de combustão (emissões de poluentes no ciclo ESC, pressão de combustão);

3) Informações sobre as condições térmicas de funcionamento (temperatura de válvulas).

Importante mencionar que estas condições foram coletadas em um motor

novo. Adiante são evidenciados os dados coletados dos três itens descritos anteriormente:

\subsubsection{Curva de potência, Torque e Consumo de Combustível}

A potência para qualquer ponto de trabalho de um motor é calculada pelo torque e rotação do motor, conforme expresso na equação (3):

$P e=M d * \omega=M d * 2 * \pi * n$

$\mathrm{Pe}=$ Potência efetiva

$\mathrm{Md}=$ Torque

$\omega=$ velocidade angular

$\mathrm{n}=$ número de revoluções do virabrequim pelo tempo

De acordo com esta equação, um aumento na potência pode ser alcançado à velocidade angular ou o torque. O consumo de combustível será indicado pelo valor específico, ou seja, dividindo pelo valor de potência. Estas informações serão utilizadas como dado de entrada para as simulações. Na Figura 
23, mostram-se os dados coletados de potência, torque e consumo de combustível específico do motor.

Figura 23 - Valores de potência, torque e consumo de combustível específico.

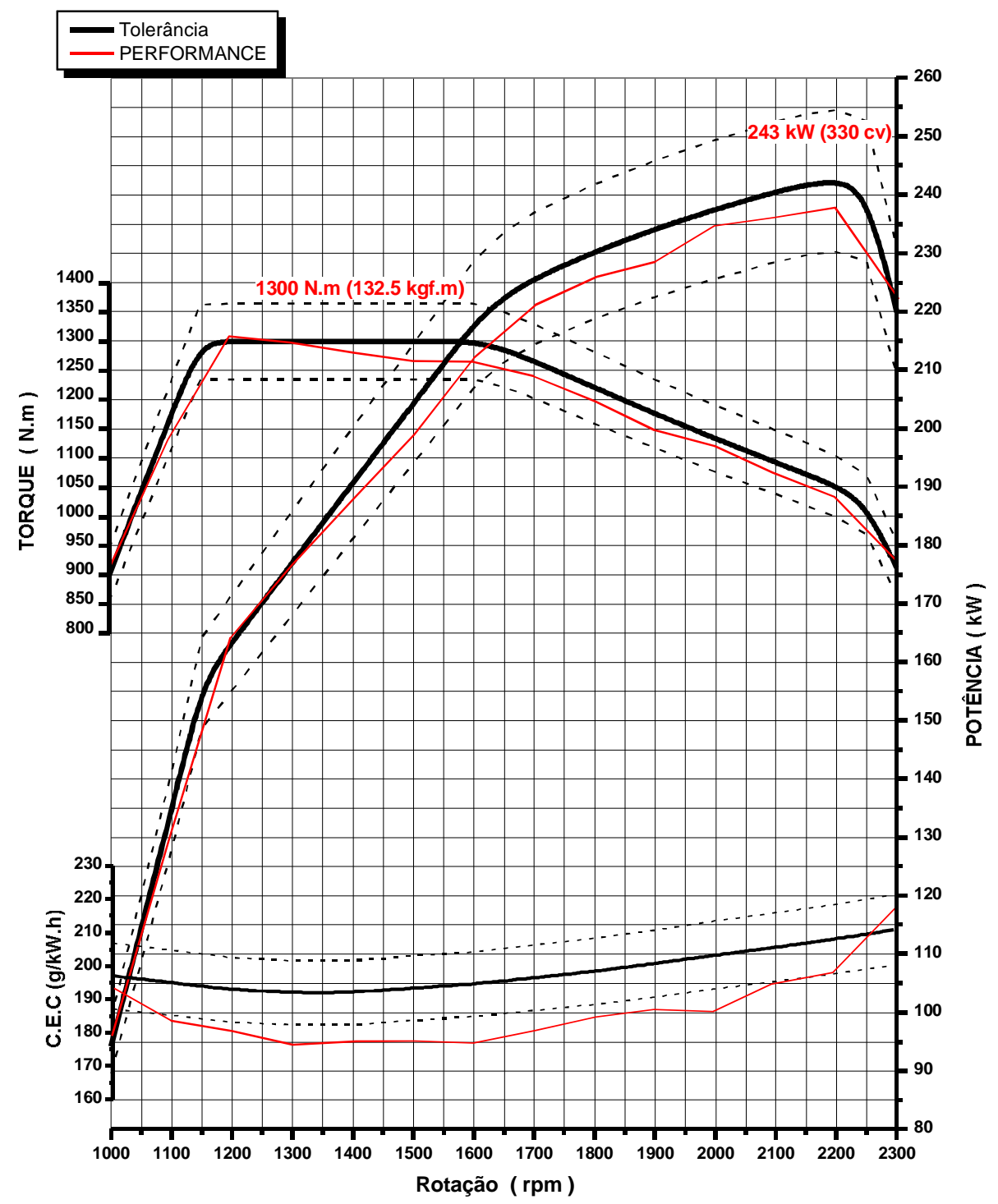

Fonte: autor da dissertação.

Como pode ser observado na Figura 23, o valor de consumo de combustível específico está abaixo do limite especificado, contudo este item quando menor não implica em problemas de desempenho e sim, um desempenho melhor que o esperado. 
5.1.2 Resultado de pressão de combustão

Os dados de pressão de combustão serviram como valores de entrada para a simulação de funcionamento do par válvula e sede de admissão. Nas Figuras 24 e 25, mostram-se os dados de pressão de combustão coletados em função da rotação do motor e pelo ângulo do virabrequim na rotação em que apresentou maior valor de pressão.

Figura 24 - Pressão de combustão máxima em função da rotação do motor.

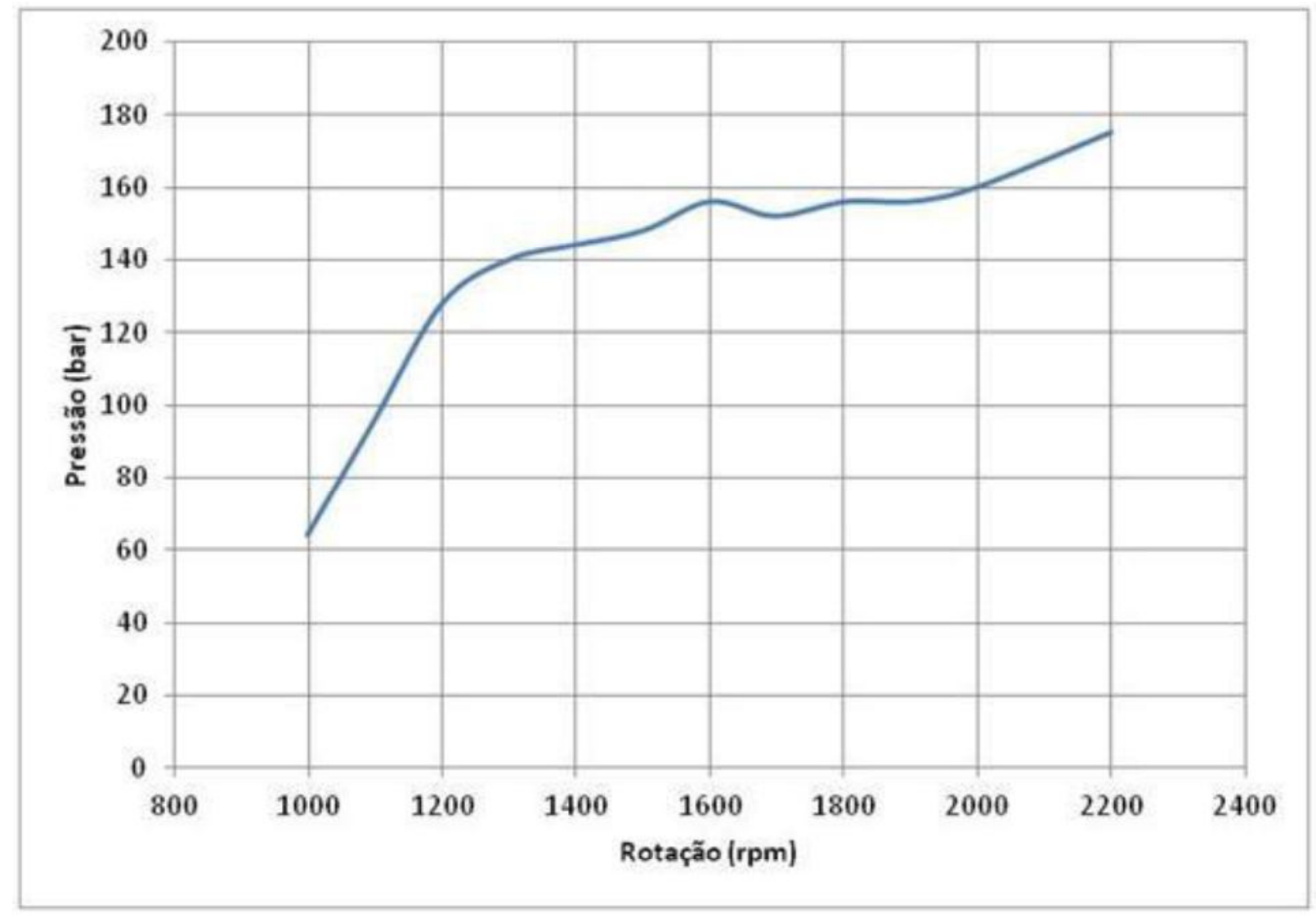

Fonte: autor da dissertação. 
Figura 25 - Pressão de combustão em função do ângulo do virabrequim na condição de maior pressão de combustão do motor -2200 rpm em plena carga.

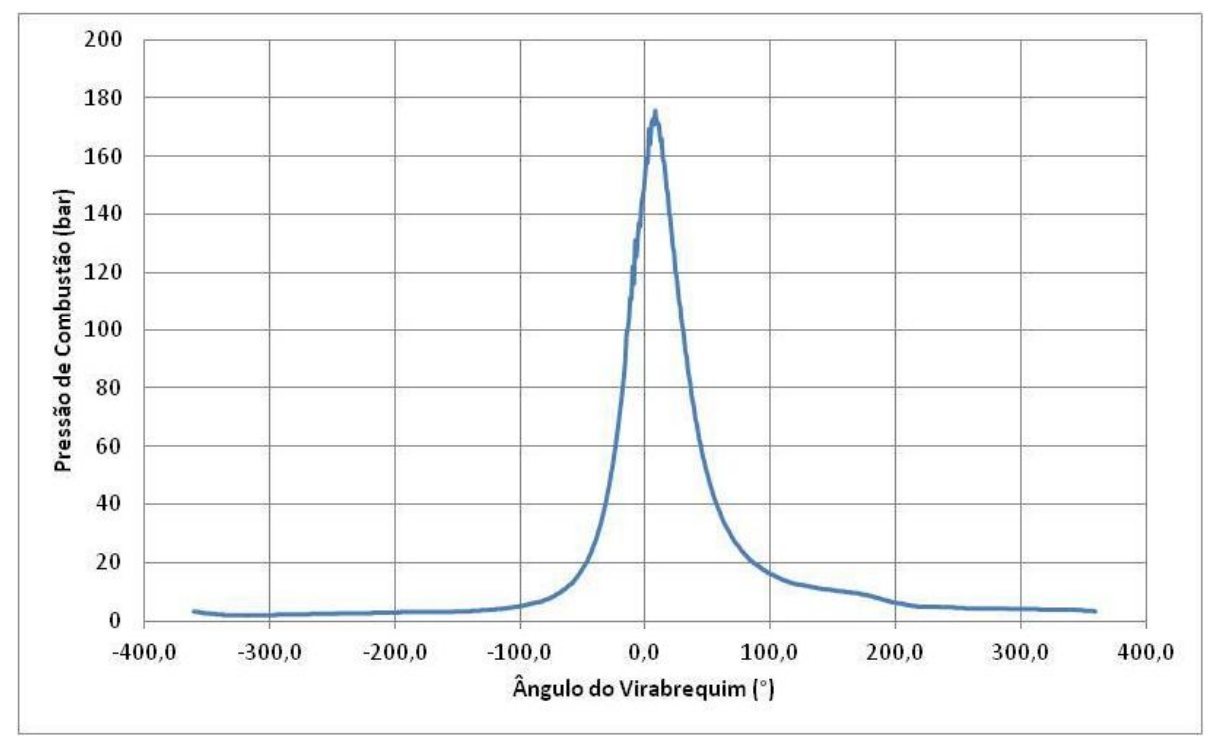

Fonte: autor da dissertação.

\subsubsection{Temperatura de válvulas}

Foram medidas as temperaturas, em operação, das válvulas de admissão. Para tanto foram preparadas válvulas adequadas para medir as temperaturas máximas durante o funcionamento do motor. A medição serviu para a análise comparativa dos valores reais de operação com o limite do material, uma vez sabendo que temperaturas elevadas de operação podem afetar negativamente as propriedades do material.

O método de medição de temperatura usa o efeito do revenimento. Devido ao efeito do revenimento a dureza do aço diminui com o aumento da temperatura durante a operação do motor. Por conseguinte, o conhecimento do comportamento do revenimento é necessário. Para esta determinação a medição de temperatura as válvulas foram fabricadas com o seguinte material e processo:

Válvulas de admissão: de material 40NiCr6 forjado, temperado e revenido a $150^{\circ} \mathrm{C}$ (material e processo utilizado é padrão do fornecedor da válvula).

As curvas de revenimento foram realizadas para cada válvula através da medição dos valores de dureza numa secção transversal. As temperaturas do forno usadas foram ajustadas com um termopar calibrado e foram mantidas durante duas horas à temperatura adequada, em cada caso. O teste de dureza (HV 2) para a determinação das curvas de revenimento foi realizada em secções metalográficas. A 
Figura 26 mostra os pontos de medição. Foram medidas 12 válvulas de admissão, que é a quantidade total de válvulas montadas por motor, que estão indicados de 11 até 112. Os pontos de medição de dureza para determinação de temperatura de operação estão indicados em vermelho e numerados de 1 a 15 . Os valores de máximas e mínimas temperaturas foram consideradas a partir dos maiores e menores valores atingidos em cada ponto do conjunto de válvulas testados.

Devido à proximidade das válvulas com relação as sedes de válvulas de admissão do motor, pode-se adotar como referência os pontos 5 e 6 de medição (região de contato da válvula com a sede de válvula), como sendo a temperatura da sede de válvula, que vária entre $317^{\circ} \mathrm{C}$ a $397^{\circ} \mathrm{C}$ conforme Figura 26 . No topo da superfície da cabeça da válvula encontra-se a máxima temperatura de trabalho encontrada, que é de $438^{\circ} \mathrm{C}$ indicada no ponto 2, conforme Figura 26 .

Figura 26 - Valores obtidos de temperaturas das válvulas de admissão do motor.
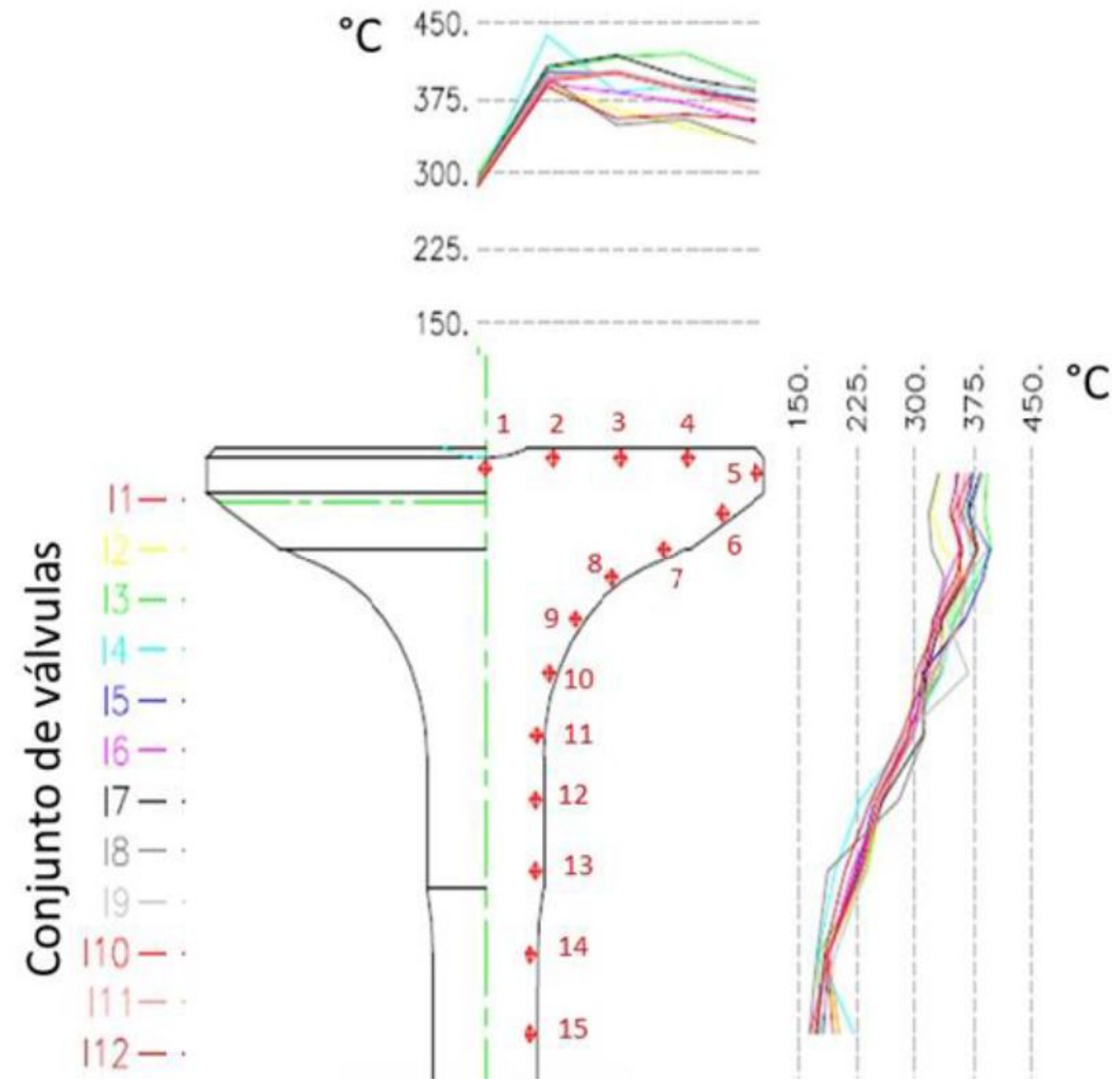

Fonte: autor da dissertação. 
As análises com as válvulas sensitivas verificaram pontualmente a temperatura de operação da válvula, por consequência mostram também a temperatura na região de contato da sede de válvula. Os resultados mostram que a temperatura máxima analisada durante o ensaio foi de $438^{\circ} \mathrm{C}$, sendo que o material da válvula $\mathrm{X} 85 \mathrm{CrMoV} 18-2$ resistente a temperatura de operação de até $600^{\circ} \mathrm{C}$ sem alterações nas suas propriedades.

\subsection{Simulações de funcionamento}

Com base nos dados coletados na etapa 1 relacionados às informações de desempenho, pressão de combustão e nas propriedades da válvula e da sede relacionado ao módulo de elasticidade e ao coeficiente de atrito, bem como às características dimensionais, foi simulado o funcionamento do par válvula e sede de admissão. A razão deste estudo, é identificar o comportamento do par válvula e sede de admissão, quando submetido às condições de trabalho para avaliar a movimentação das superfícies da válvula e da sede de válvula em contato e pressões de contato. Na Tabela 8 é apresentado um resumo dos dados de entrada da simulação.

Tabela 8 - Dados de entrada da simulação.

\begin{tabular}{l|l|l}
\hline Item & Válvula & Sede \\
\hline Pressão de Combustão & Baseado nos dados apresentados na Figura 25 \\
\hline Módulo de elasticidade & $200000 \mathrm{MPa}$ & $150000 \mathrm{MPa}$ \\
\hline Geometria & Item 4.1 .1 & Item 4.1 .2 \\
\hline Massa & $0,075 \mathrm{~kg}$ & $0,013 \mathrm{~kg}$ \\
\hline Coeficiente de atrito & 0,4 (conforme ROSEMBERG, 1982) \\
\hline
\end{tabular}

Fonte: autor da dissertação.

As Figuras 27 e 28 mostram os dados de movimentação das superfícies da válvula e da sede de válvula em contato. A Figura 28 é uma ampliação da região de contato da válvula com a sede de válvula. A sede de válvula é considerada um corpo rígido, sendo que foi utilizado para análise software de CAE denominado CATIA. 
Figura 27 - Através de análise de CAE foi verificado o movimento da válvula de admissão em relação a sede, com base nos dados de combustão, massa e rigidez do material (valores em milímetros).

\section{Deslocamento $(\mathrm{mm})$}
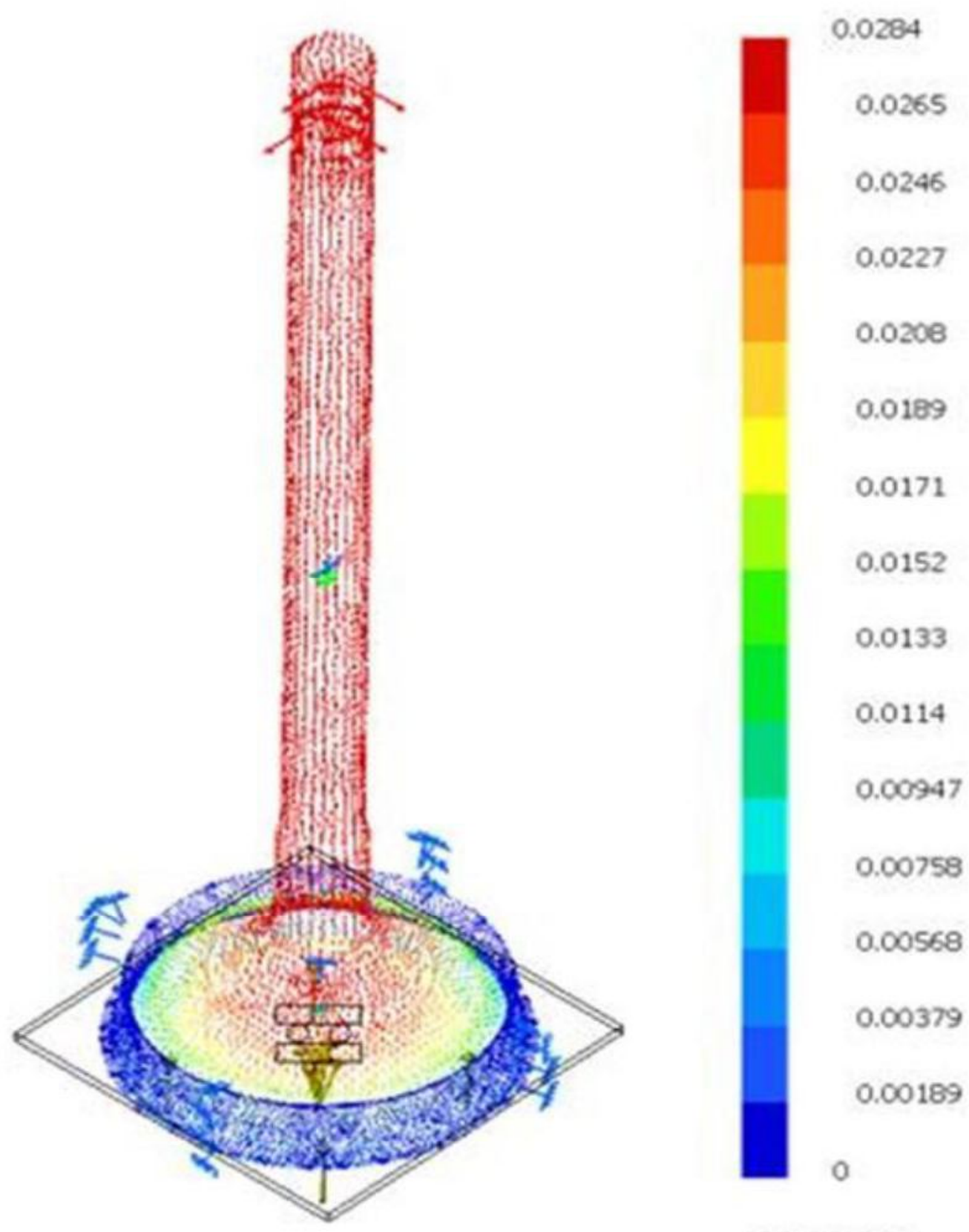

On Boundry

Fonte: autor da dissertação. 
Figura 28 - Análise de movimentação da cabeça da válvula em relação a sede, sendo que os tons em azul demostram nenhuma ou baixa movimentação e os tons em vermelho demostram as maiores movimentações (valores em milímetros).

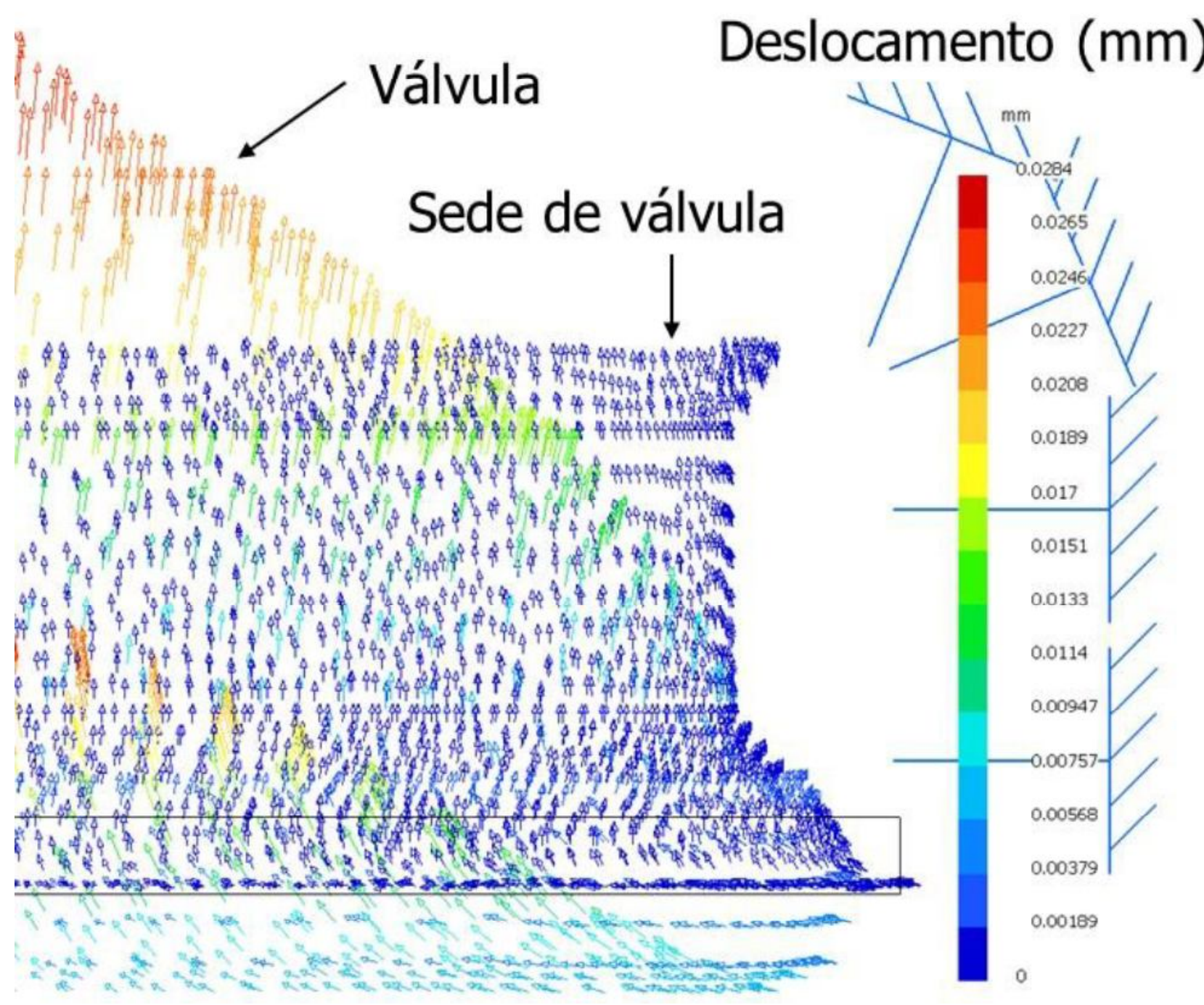

Fonte: autor da dissertação.

Nas Figuras 29 (a) e 29 (b), mostram-se os valores de pressão de contato com relação a diferença entre o ângulo formado entre a válvula e a sede de admissão, para tanto foi utilizado software de CAE (Samcef). 
Figura 29 - (a) Deflexão da cabeça da Válvula com diferentes ângulos de assentamento entre válvula e sede de válvula. (b) Pressão de contato entre válvula e sede de válvula com diferentes ângulos de assentamento entre válvula e sede de válvula.

\section{Ângulo entre Válvula e Sede de Válvula}

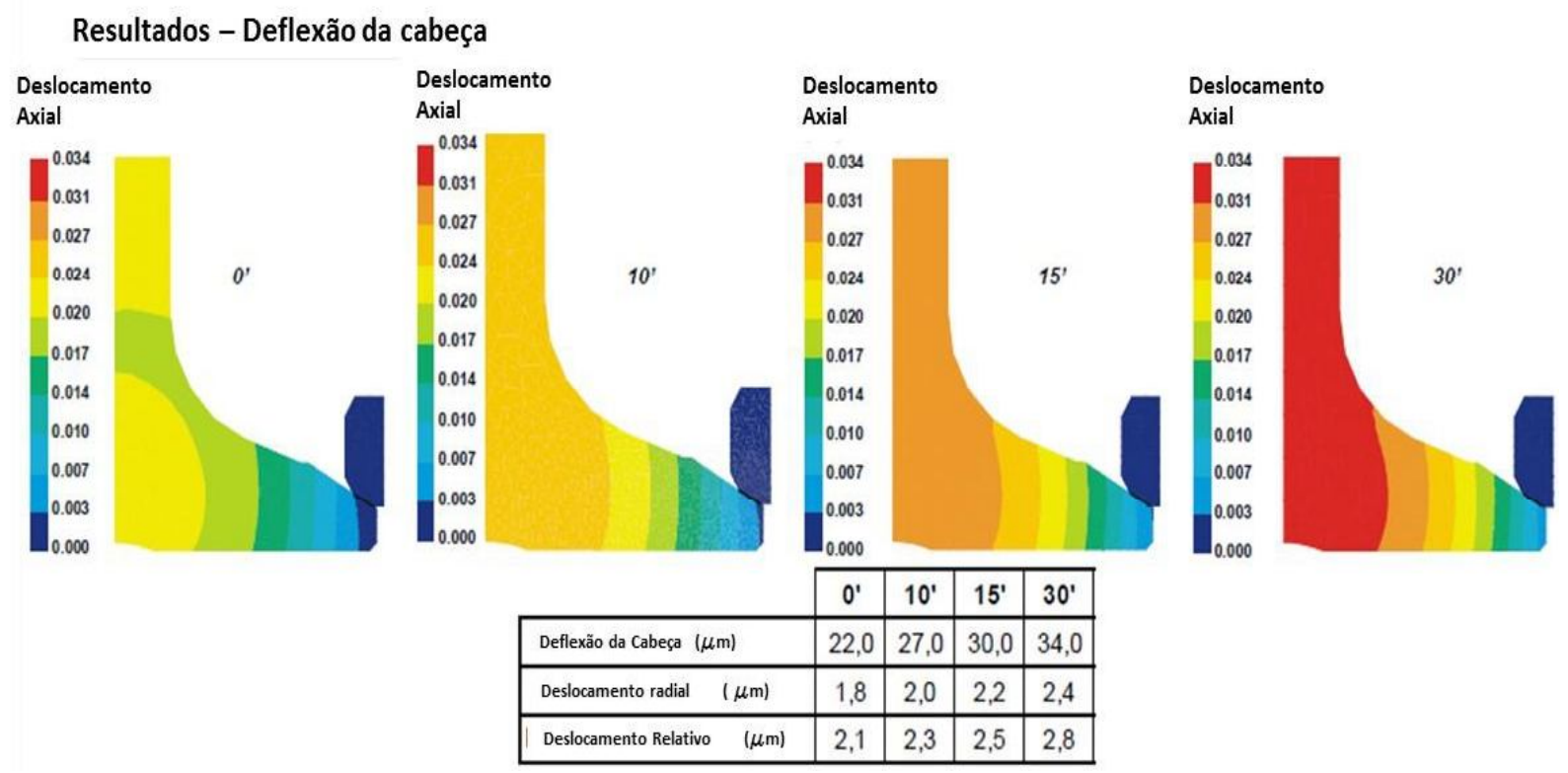

a

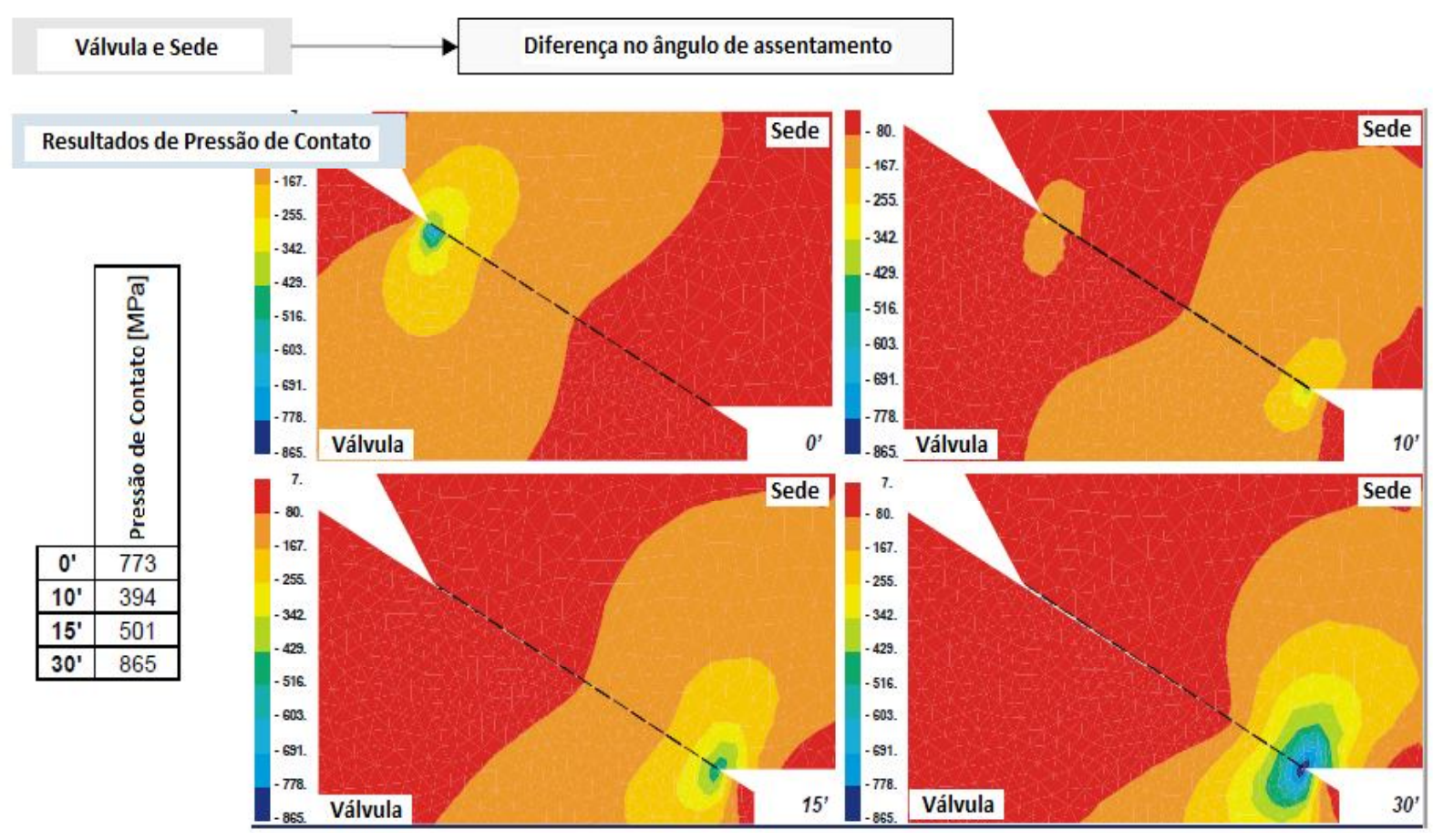

b

Fonte: autor da dissertação. 
Para melhor entendimento do que ocorre durante o trabalho com o par tribológico válvula e sede de válvula, relacionado à movimentação, foi conduzida a simulação, pois é difícil a observação do conjunto em condição de operação real, uma vez que se tratam de componentes internos do motor, que trabalham em uma região em condições extremas de temperatura e pressão. Os resultados mostram que durante o funcionamento existe uma movimentação relativa da válvula em relação a sede de válvula da ordem de $5 \mu \mathrm{m}$ até $7 \mu \mathrm{m}$ de deslocamento na região de contato da válvula com a sede de válvula.

Os trabalhos realizados na simulação também mostram informações sobre a influência do design e do material. Quanto ao design, através de análises de elementos finitos, pode-se avaliar os valores de pressão de contato, tal como mostra a Figura 29 (a) e (b), baseado nas diferenças entre o ângulo formado pela válvula e sede de válvula em contato. Este fator é importante ter conhecimento, pois os desgastes podem ser acentuados conforme for maior o deslocamento relativo entre válvula e sede de válvula, bem como, quanto maior for à pressão de contato.

\subsection{Caracterização das amostras}

As amostras foram caracterizadas e separadas por teste, sendo que foram avaliadas as propriedades físicas e químicas e medições dimensionais das válvulas e sedes de admissão. As atividades metalúrgicas foram realizadas em uma amostra do mesmo lote de peças que foram montadas nos motores. As analises dimensionais foram conduzidas em todas as peças montadas para testes.

\subsubsection{Caracterização das válvulas de admissão}

Para caracterizar a válvula metalurgicamente, foi verificada uma amostra do mesmo lote de fabricação das peças que foram submetidas aos ensaios. $\mathrm{Na}$ Figura 30, analisa-se a microestrutura da região da cabeça da válvula realizada em microscópio ótico. A Tabela 9 mostra os resultados comentados da análise metalográfica da válvula de admissão. 
Figura 30 - Micrografia em microscópio óptico da válvula, mostrando a estrutura da matriz na região da cabeça da válvula - martensítica com carbonetos bem distribuídos. Ataque: Água régia.

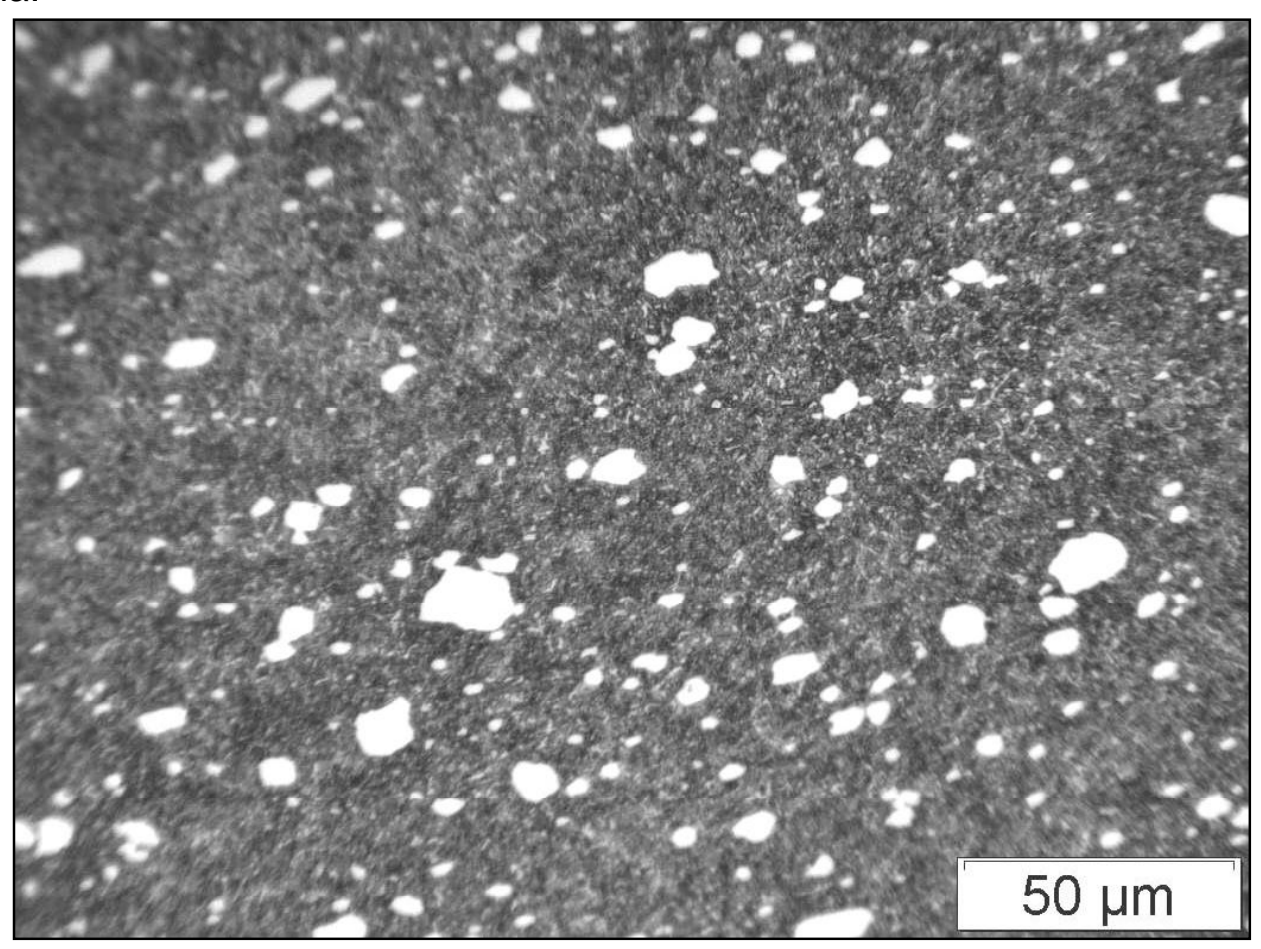

Fonte: autor da dissertação.

Tabela 9 - Resultados da análise metalográfica da válvula.

\begin{tabular}{|c|c|c|}
\hline Item & Especificado & Encontrado \\
\hline & & Amostra \\
\hline 1 & Estrutura da matriz: Beneficiada & Beneficiada \\
\hline 2 & Carbonetos: Distribuídos Uniformemente & Distribuídos uniformemente \\
\hline 3 & Descarbonetação: Ausente & Ausente \\
\hline 4 & Espessura da camada de cromo: 3 a $11 \mu \mathrm{m}$ & $6 \mu \mathrm{m}$ \\
\hline 5 & Trincas e dobras: Ausentes & Ausentes \\
\hline 6 & $\begin{array}{l}\text { Profundidade da têmpera por indução na ponta: } 14 \\
\text { a } 21 \mathrm{~mm}\end{array}$ & $20,2 \mathrm{~mm}$ \\
\hline 7 & $\begin{array}{l}\text { Profundidade da têmpera por indução na região de } \\
\text { assentamento da sede - (Rht } 385 \mathrm{HV} 1) \text { - Posição } \\
\text { A: } 1,6 \mathrm{~mm}\end{array}$ & Têmpera total \\
\hline
\end{tabular}

Fonte: autor da dissertação. 
Foram realizadas análises químicas, conforme Tabela 10, para verificação da composição química da válvula e ensaios físicos de dureza em todas as regiões da válvula, conforme Tabela 11.

Tabela 10 - Resultados da análise química da válvula.

\begin{tabular}{l|c|c|c|c|c|c|c|c}
\hline \multicolumn{7}{c}{ COMPOSIÇÃO QUÍMICA (\% EM MASSA) - Amostra } \\
\hline Item & $\mathbf{1}$ & $\mathbf{2}$ & $\mathbf{3}$ & $\mathbf{4}$ & $\mathbf{5}$ & $\mathbf{6}$ & $\mathbf{7}$ & $\mathbf{8}$ \\
\hline \multirow{2}{*}{ Especificação } & $\mathbf{C}$ & $\mathbf{S i}$ & $\mathbf{M n}$ & $\mathbf{P}$ & $\mathbf{S}$ & $\mathbf{C r}$ & $\mathbf{M o}$ & $\mathbf{V}$ \\
\hline & $\begin{array}{c}0,80 \\
\mathrm{a}\end{array}$ & $\begin{array}{c}1,00 \\
\mathrm{max}\end{array}$ & $\begin{array}{c}1,50 \\
\max \end{array}$ & $\begin{array}{c}0,04 \\
\max \end{array}$ & $\begin{array}{c}0,03 \\
\max \end{array}$ & $\begin{array}{c}16,50 \\
\mathrm{a} \\
18,50\end{array}$ & $\begin{array}{c}2,00 \\
\mathrm{a} \\
2,50\end{array}$ & $\begin{array}{c}0,30 \\
\mathrm{a} \\
0,60\end{array}$ \\
\hline \multirow{2}{*}{ Resultados } & 0,85 & 0,31 & 1,15 & 0,025 & 0,004 & 16,55 & 2,12 & 0,35 \\
& & & & & & & & \\
\hline
\end{tabular}

Fonte: autor da dissertação.

Tabela 11 - Resultados dos ensaios físicos da válvula.

\begin{tabular}{c|l|c}
\hline Item & \multicolumn{1}{|c|}{ Especificado } & Encontrado \\
\hline & \multicolumn{1}{|c}{ Amostra } \\
\hline 1 & Dureza na Haste / Cabeça: 35 a 42 HRC & $40,4 \mathrm{HRC}$ \\
\hline 2 & Dureza na região dos canais: 45 a 60 HRC & $50,4 \mathrm{HRC}$ \\
\hline 3 & $\begin{array}{l}\text { Dureza na região de assentamento da sede: } \\
\text { 45 HRC mínimo }\end{array}$ & $50,8 \mathrm{HRC}$ \\
\hline
\end{tabular}

Fonte: autor da dissertação.

As medições dimensionais foram conduzidas nas válvulas que equiparam os motores dos ensaios de durabilidade em dinamômetro e ensaio veicular. As grandezas medidas foram ângulo da cabeça da válvula e o batimento entre a cabeça da válvula e a haste da válvula, sendo que os valores estão disponíveis na Tabela 12. 
Tabela 12 - Medição dimensional divididas por motor, visando garantir a conformidade das medições com o projeto da válvula.

\begin{tabular}{|c|c|c|c|c|c|}
\hline Motor & Válvula & $\begin{array}{l}\text { Ângulo }\left({ }^{\circ}\right) \text { - } \\
\text { Especificado }\end{array}$ & $\begin{array}{l}\text { Ângulo }\left({ }^{\circ}\right) \text { - } \\
\text { Encontrado }\end{array}$ & $\begin{array}{c}\text { Batimento } \\
(\mathrm{mm})- \\
\text { Especificado }\end{array}$ & $\begin{array}{c}\text { Batimento } \\
(\mathrm{mm})- \\
\text { Encontrado }\end{array}$ \\
\hline \multirow{12}{*}{$\begin{array}{c}\text { Ensaio de } \\
\text { durabilidade } \\
\text { em } \\
\text { dinamômetro }\end{array}$} & 1 & $120^{\circ} 10^{\prime}\left(+/-15^{\prime}\right)$ & 120:04:19 & 0,03 & 0,0157 \\
\hline & 2 & $120^{\circ} 10^{\prime}\left(+/-15^{\prime}\right)$ & 120:04:30 & 0,03 & 0,0175 \\
\hline & 3 & $120^{\circ} 10^{\prime\left(+/-15^{\prime}\right)}$ & $120: 06: 48$ & 0,03 & 0,0208 \\
\hline & 4 & $120^{\circ} 10^{\prime}\left(+/-15^{\prime}\right)$ & $120: 07: 46$ & 0,03 & 0,0180 \\
\hline & 5 & $120^{\circ} 10^{\prime}\left(+/-15^{\prime}\right)$ & 120:09:28 & 0,03 & 0,0110 \\
\hline & 6 & $120^{\circ} 10^{\prime}\left(+/-15^{\prime}\right)$ & 120:04:05 & 0,03 & 0,0175 \\
\hline & 7 & $120^{\circ} 10^{\prime}\left(+/-15^{\prime}\right)$ & $120: 07: 15$ & 0,03 & 0,0127 \\
\hline & 8 & $120^{\circ} 10^{\prime}\left(+/-15^{\prime}\right)$ & 120:08:00 & 0,03 & 0,0146 \\
\hline & 9 & $120^{\circ} 10^{\prime\left(+/-15^{\prime}\right)}$ & $120: 06: 17$ & 0,03 & 0,0116 \\
\hline & 10 & $120^{\circ} 10^{\prime}\left(+/-15^{\prime}\right)$ & 120:08:07 & 0,03 & 0,0124 \\
\hline & 11 & $120^{\circ} 10^{\prime}\left(+/-15^{\prime}\right)$ & 120:03:57 & 0,03 & 0,0163 \\
\hline & 12 & $120^{\circ} 10^{\prime\left(+/-15^{\prime}\right)}$ & 120:05:31 & 0,03 & 0,0135 \\
\hline \multirow{12}{*}{$\begin{array}{l}\text { Ensaio de } \\
\text { durabilidade } \\
\text { veicular }\end{array}$} & 1 & $120^{\circ} 10^{\prime}\left(+/-15^{\prime}\right)$ & 120:08:20 & 0,03 & 0,0135 \\
\hline & 2 & $120^{\circ} 10^{\prime}\left(+/-15^{\prime}\right)$ & $120: 10: 02$ & 0,03 & 0,0109 \\
\hline & 3 & $120^{\circ} 10^{\prime}\left(+/-15^{\prime}\right)$ & 120:13:14 & 0,03 & 0,0203 \\
\hline & 4 & $120^{\circ} 10^{\prime\left(+/-15^{\prime}\right)}$ & $120: 04: 52$ & 0,03 & 0,0155 \\
\hline & 5 & $120^{\circ} 10^{\prime}\left(+/-15^{\prime}\right)$ & 120:04:25 & 0,03 & 0,0133 \\
\hline & 6 & $120^{\circ} 10^{\prime}\left(+/-15^{\prime}\right)$ & 120:08:22 & 0,03 & 0,0159 \\
\hline & 7 & $120^{\circ} 10^{\prime\left(+/-15^{\prime}\right)}$ & 120:08:30 & 0,03 & 0,0201 \\
\hline & 8 & $120^{\circ} 10^{\prime\left(+/-15^{\prime}\right)}$ & $120: 16: 27$ & 0,03 & 0,0163 \\
\hline & 9 & $120^{\circ} 10^{\prime\left(+/-15^{\prime}\right)}$ & $120: 04: 45$ & 0,03 & 0,0147 \\
\hline & 10 & $120^{\circ} 10^{\prime}\left(+/-15^{\prime}\right)$ & 120:06:41 & 0,03 & 0,0142 \\
\hline & 11 & $120^{\circ} 10^{\prime}\left(+/-15^{\prime}\right)$ & $120: 10: 52$ & 0,03 & 0,0189 \\
\hline & 12 & $120^{\circ} 10^{\prime}\left(+/-15^{\prime}\right)$ & 120:11:56 & 0,03 & 0,0145 \\
\hline
\end{tabular}

Fonte: autor da dissertação.

5.3.2 Caracterização das sedes de válvulas de admissão

Assim como conduzido para a válvula de admissão, para a caracterização metalúrgica da sede válvulas de admissão foi analisada uma peça do mesmo lote que foi submetido aos ensaios.

Nas Figuras 31 e 32, mostram-se a microestrutura da sede de válvula de admissão realizada em microscópio ótico em ambos os casos. A Tabela 13 mostra os resultados comentados da análise metalográfica da sede de válvula de admissão. 
Figura 31 - Micrografia em microscópio óptico da sede de válvula, mostrando a distribuição homogênea dos poros na matriz - poros preenchidos com cobre. Ataque: sem ataque.

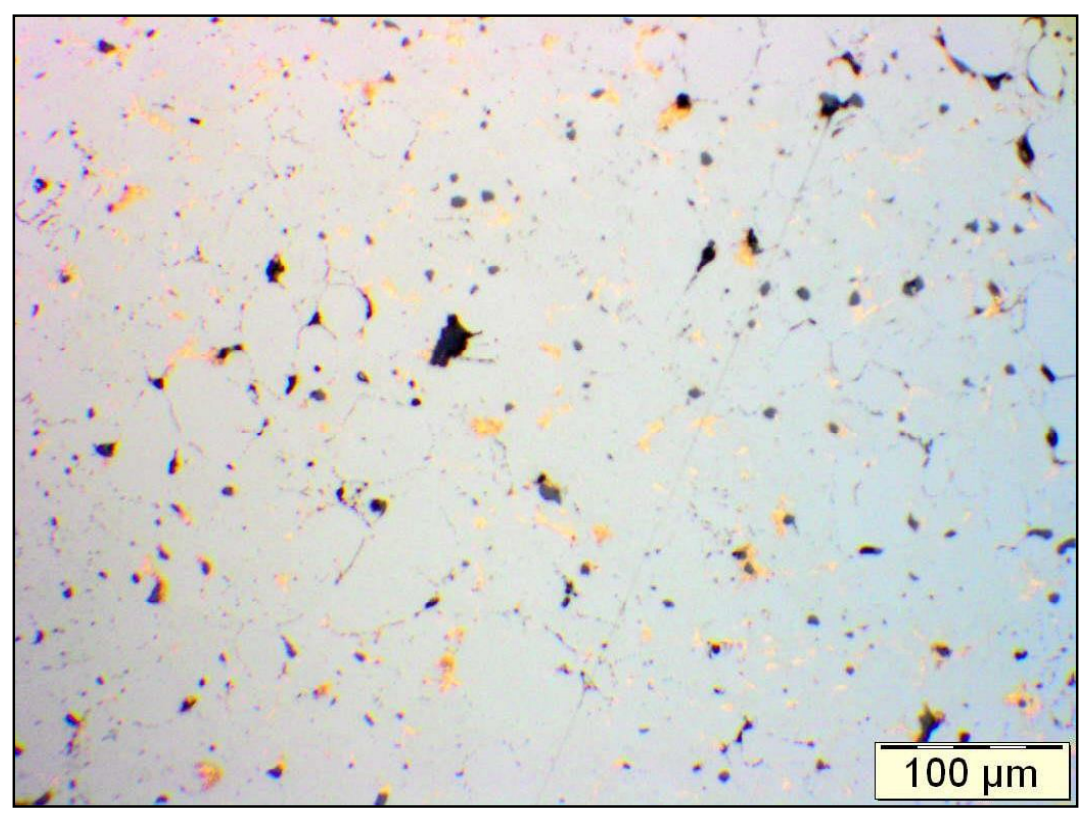

Fonte: autor da dissertação.

Figura 32 - Micrografia em microscópio óptico da sede de válvula, mostrando a estrutura da matriz - carbonetos distribuídos fina e uniformemente, e uma fase intermetálica em uma matriz martensítica. Ataque: Nital 3\%.

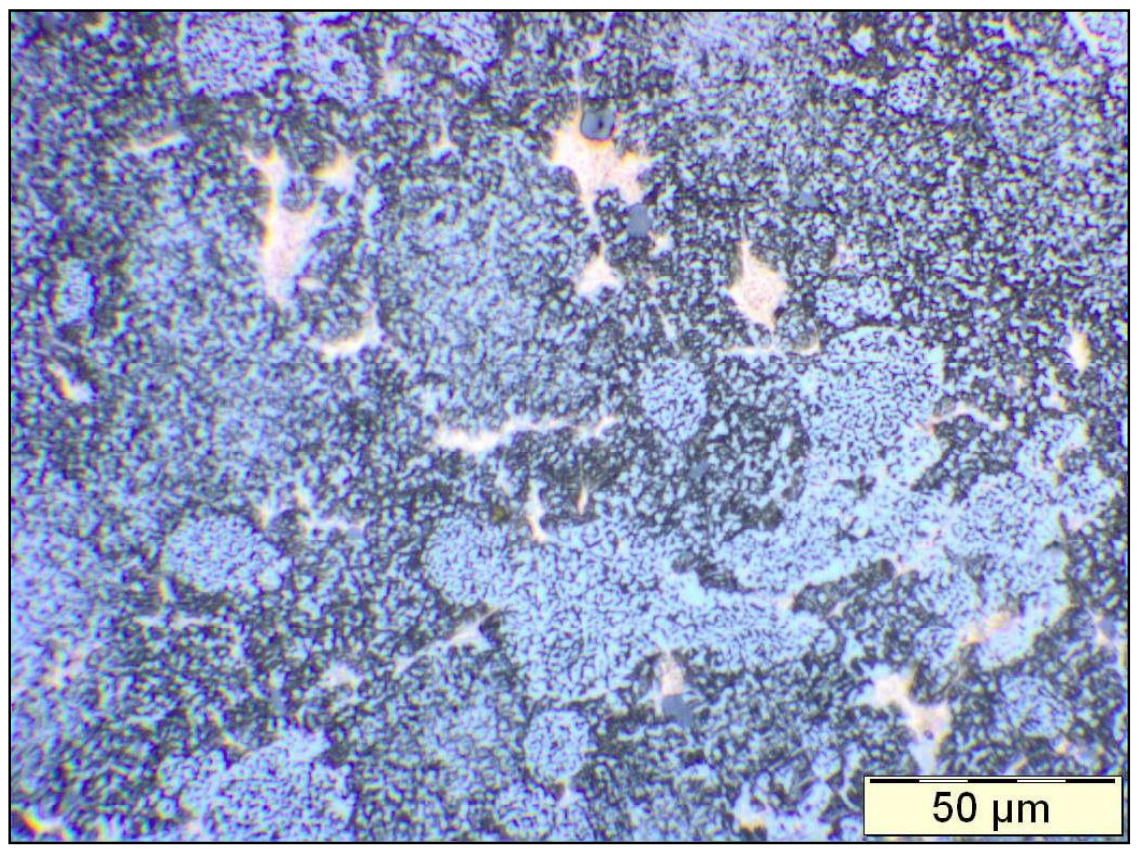

Fonte: autor da dissertação. 
Tabela 13 - Resultados da análise metalográfica da sede de válvula.

\begin{tabular}{c|l|l}
\hline Item & \multicolumn{1}{|c}{ Especificado } & \multicolumn{1}{|c}{ Encontrado } \\
\hline 1 & Processo de fabricação: Sinterizada & Sinterizada \\
\hline 2 & Estrutura da matriz: Martensítica & Martensítica \\
\hline 3 & Carbonetos: Distribuição uniforme & Distribuição uniforme \\
\hline 4 & Perlita: Ausente & Ausente \\
\hline 5 & Compostos intermetálicos: Presentes & Presentes \\
\hline 6 & Poros: Cobertos com cobre & Em ordem \\
\hline 7 & $\begin{array}{l}\text { Defeitos superficiais na região compreendida como P1 e P4 } \\
\text { (assento): Ausentes }\end{array}$ & Ausentes \\
\hline 8 & $\begin{array}{l}\text { Defeitos superficiais nas demais regiões: Máximo 5 defeitos } \\
\text { por peça, com diâmetro e/ou profundidade inferior a 0,8 mm } \\
\text { e equidistantes entre si, no mínimo, 3,2 mm }\end{array}$ & Em ordem \\
\hline 9 & Trincas e/ou junta fria: Ausente & Ausente \\
\hline
\end{tabular}

Fonte: autor da dissertação.

Foram realizadas análises químicas, conforme Tabela 14, para verificação da composição química da sede de válvula e ensaios físicos de dureza em três pontos na superfície de contato com a sede de válvula, sendo que os resultados mostram uma dureza de 49,0 até $51,6 \mathrm{HRC}$ e o especificado é 45 a $55 \mathrm{HRC}$.

Tabela 14 - Resultados da análise química da sede de válvula.

\begin{tabular}{|c|c|c|c|c|c|c|c|c|c|c|c|}
\hline \multicolumn{12}{|c|}{ COMPOSIÇÃO QUÍMICA (\% EM MASSA) - Amostra } \\
\hline Item & 1 & 2 & 3 & 4 & 5 & 6 & 7 & 8 & 9 & 10 & 11 \\
\hline & $C$ & Co & Mo & $\mathrm{W}$ & $\mathrm{V}$ & $\mathrm{Cr}$ & $\mathrm{Si}$ & $\mathrm{Mn}$ & $\mathrm{S}$ & $\mathrm{Cu}$ & $\mathbf{F e}$ \\
\hline \multirow[t]{2}{*}{ Especificação } & 0,80 & 15,0 & 9,0 & 2,5 & 1,3 & 3,5 & 0,5 & 0,3 & 0,15 & 10,0 & \multirow[t]{2}{*}{ Restante } \\
\hline & 1,30 & 22,0 & 14,0 & 4,5 & 2,3 & 5,5 & 2,0 & 1,5 & 0,75 & 20,0 & \\
\hline Resultados & 1,06 & 16,22 & 12,14 & 3,63 & 1,46 & 4,36 & 0,74 & 0,43 & 0,28 & 15,01 & Restante \\
\hline
\end{tabular}

Fonte: autor da dissertação.

As avaliações dimensionais foram conduzidas nas sedes de válvulas que equiparam os motores dos ensaios de durabilidade em dinamômetro e veicular. As grandezas medidas foram ângulo da sede de válvula e batimento entre guia de válvula e sede de válvula, para as 12 sedes de válvulas de admissão e estão disponíveis na Tabela 15. 
Tabela 15 - Medição dimensional divididas por motor, visando garantir a conformidade das medições com o projeto da sede de válvula montada no cabeçote.

\begin{tabular}{|c|c|c|c|c|c|}
\hline Motor & Sede & $\begin{array}{l}\text { Ângulo }\left({ }^{\circ}\right) \text { - } \\
\text { Especificado }\end{array}$ & $\begin{array}{l}\text { Ângulo }\left({ }^{\circ}\right) \text { - } \\
\text { Encontrado }\end{array}$ & $\begin{array}{c}\text { Batimento } \\
(\mathrm{mm})- \\
\text { Especificado }\end{array}$ & $\begin{array}{c}\text { Batimento } \\
(\mathrm{mm})- \\
\text { Encontrado }\end{array}$ \\
\hline \multirow{12}{*}{$\begin{array}{c}\text { Ensaio de } \\
\text { durabilidade } \\
\text { em } \\
\text { dinamômetro }\end{array}$} & 1 & $120^{\circ}\left(+0^{\prime} / 15^{\prime}\right)$ & 119:46:17 & 0,04 & 0,0263 \\
\hline & 2 & $120^{\circ}\left(+0^{\prime} / 15^{\prime}\right)$ & 119:48:15 & 0,04 & 0,0204 \\
\hline & 3 & $120^{\circ}\left(+0^{\prime} / 15^{\prime}\right)$ & 119:47:50 & 0,04 & 0,0177 \\
\hline & 4 & $120^{\circ}\left(+0^{\prime} / 15^{\prime}\right)$ & 119:45:09 & 0,04 & 0,0320 \\
\hline & 5 & $120^{\circ}\left(+0^{\prime} / 15^{\prime}\right)$ & 119:47:28 & 0,04 & 0,0286 \\
\hline & 6 & $120^{\circ}\left(+0^{\prime} / 15^{\prime}\right)$ & 119:46:37 & 0,04 & 0,0307 \\
\hline & 7 & $120^{\circ}\left(+0^{\prime} / 15^{\prime}\right)$ & 119:53:31 & 0,04 & 0,0278 \\
\hline & 8 & $120^{\circ}\left(+0^{\prime} / 15^{\prime}\right)$ & 119:52:46 & 0,04 & 0,0206 \\
\hline & 9 & $120^{\circ}\left(+0^{\prime} / 15^{\prime}\right)$ & 119:45:20 & 0,04 & 0,0310 \\
\hline & 10 & $120^{\circ}\left(+0^{\prime} / 15^{\prime}\right)$ & 119:48:25 & 0,04 & 0,0274 \\
\hline & 11 & $120^{\circ}\left(+0^{\circ} / 15^{\prime}\right)$ & 119:46:28 & 0,04 & 0,0313 \\
\hline & 12 & $120^{\circ}\left(+0^{\prime} / 15^{\prime}\right)$ & 119:46:17 & 0,04 & 0,0343 \\
\hline \multirow{12}{*}{$\begin{array}{l}\text { Ensaio de } \\
\text { durabilidade } \\
\text { veicular }\end{array}$} & 1 & $120^{\circ}\left(+0^{\prime} / 15^{\prime}\right)$ & 119:46:51 & 0,04 & 0,0277 \\
\hline & 2 & $120^{\circ}\left(+0^{\prime} / 15^{\prime}\right)$ & 119:47:15 & 0,04 & 0,0315 \\
\hline & 3 & $120^{\circ}\left(+0^{\prime} / 15^{\prime}\right)$ & $119: 45: 02$ & 0,04 & 0,0326 \\
\hline & 4 & $120^{\circ}\left(+0^{\prime} / 15^{\prime}\right)$ & 119:49:38 & 0,04 & 0,0259 \\
\hline & 5 & $120^{\circ}\left(+0^{\prime} / 15^{\prime}\right)$ & 119:46:30 & 0,04 & 0,0366 \\
\hline & 6 & $120^{\circ}\left(+0^{\prime} / 15^{\prime}\right)$ & $119: 45: 47$ & 0,04 & 0,0298 \\
\hline & 7 & $120^{\circ}\left(+0^{\prime} /-15^{\prime}\right)$ & 119:49:27 & 0,04 & 0,0261 \\
\hline & 8 & $120^{\circ}\left(+0^{\prime} / 15^{\prime}\right)$ & 119:53:24 & 0,04 & 0,0384 \\
\hline & 9 & $120^{\circ}\left(+0^{\prime} / 15^{\prime}\right)$ & 119:44:25 & 0,04 & 0,0349 \\
\hline & 10 & $120^{\circ}\left(+0^{\prime} / 15^{\prime}\right)$ & $119: 46: 33$ & 0,04 & 0,0289 \\
\hline & 11 & $120^{\circ}\left(+0^{\prime} / 15^{\prime}\right)$ & 119:48:35 & 0,04 & 0,0373 \\
\hline & 12 & $120^{\circ}\left(+0^{\prime} / 15^{\prime}\right)$ & 119:55:12 & 0,04 & 0,0326 \\
\hline
\end{tabular}

Fonte: autor da dissertação.

Observa-se que a diferença entre o ângulo de assentamento entre válvula e sede de válvula está na ordem de 25', quando analisamos os valores doa ângulos das válvulas, conforme Tabela 12 e os valores dos ângulos da sede de válvula, conforme Tabela 15.

\subsection{Montagem dos motores}

Os motores foram montados em ambiente controlado, com as amostras de sede de válvulas e válvulas controladas quanto ao dimensional isoladamente. Durante esta etapa foram medidos os parâmetros de conjuntos relacionados à altura da válvula e regulagem de folga de válvula. As Figuras 33 e 34 auxiliam no entendimento das medições de conjunto mencionadas. A Figura 33 mostra a medição de profundidade da válvula, sendo que conhecendo a diferença deste valor 
antes e após o ensaio é possível determinar o desgaste do par tribológico válvula e sede de válvula de admissão.

Figura 33 - (a) mostra onde o relógio é referenciado (face do cabeçote) e a Figura (b) mostra qual é a região da válvula é verificada a profundidade da mesma em relação a face do cabeçote.

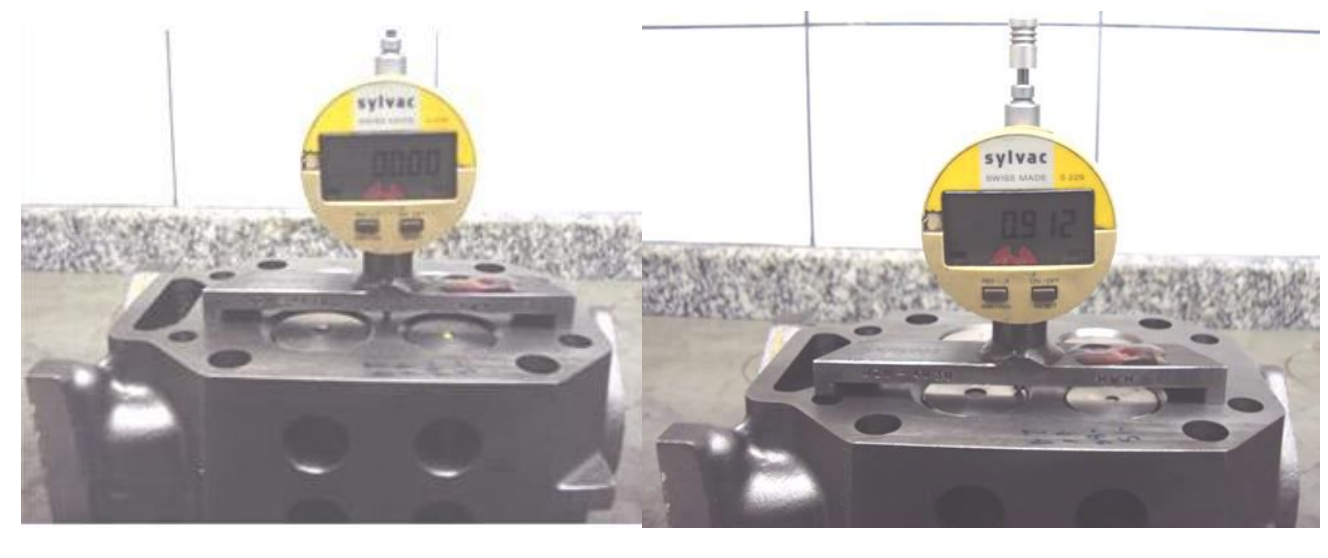

a

b

Fonte: autor da dissertação.

Na Figura 34, mostra-se a região em que é regulada a folga de válvula, sendo que é a mesma maneira que foi realizada a verificação de folga ao longo do teste veicular. Esta atividade é realizada durante a montagem do motor e também a cada $15000 \mathrm{~km}$ para ensaio veicular.

Figura 34 - Checagem e regulagem de folga de válvula (a) mostra o operador verificando com lâmina a folga entre o balanceiro e a válvula e (b) mostra o detalhe da região.

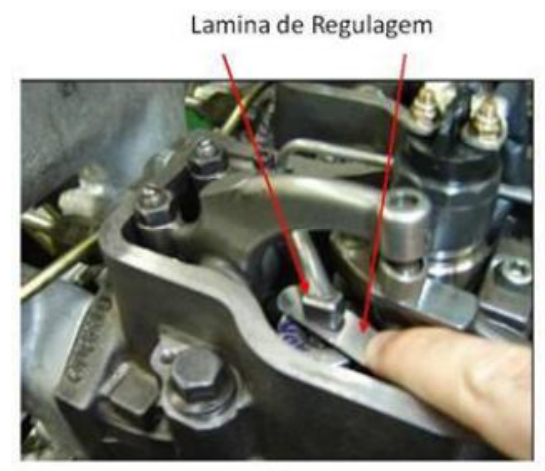

a

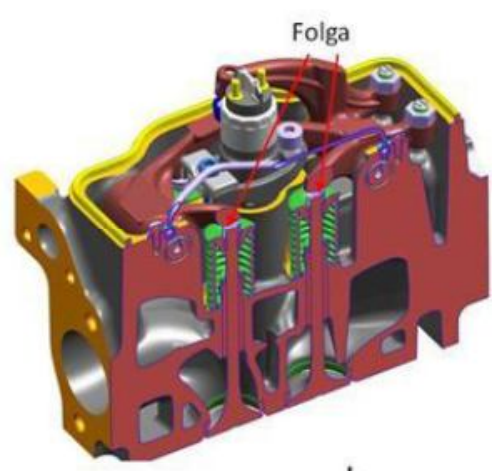

$b$

Fonte: autor da dissertação. 
Tabela 16 - Medição dimensional inicial dos motores, visando garantir a conformidade das medições com o projeto. Os valores de regulagem de folga de válvula devem estar entre 0,2 $\mathrm{mm}$ até $0,4 \mathrm{~mm}$ e de profundidade inicial de $0,9 \mathrm{~mm}$ até $1,00 \mathrm{~mm}$.

\begin{tabular}{|c|c|c|c|c|c|c|c|c|c|c|c|c|c|}
\hline \multirow{4}{*}{ Motor } & \multicolumn{13}{|c|}{ Dimensional Cabeçote (valores em milímetros) } \\
\hline & \multirow{3}{*}{ Controle } & \multirow{2}{*}{\multicolumn{2}{|c|}{$\begin{array}{l}\text { Cilindro } 01 \\
\text { Admissão }\end{array}$}} & \multirow{2}{*}{\multicolumn{2}{|c|}{$\begin{array}{l}\text { Cilindro } 02 \\
\text { Admissão }\end{array}$}} & \multirow{2}{*}{\multicolumn{2}{|c|}{$\begin{array}{c}\text { Cilindro } 03 \\
\text { Admissão }\end{array}$}} & \multirow{2}{*}{\multicolumn{2}{|c|}{$\begin{array}{c}\text { Cilindro } 04 \\
\text { Admissão } \\
\end{array}$}} & \multirow{2}{*}{\multicolumn{2}{|c|}{$\begin{array}{l}\text { Cilindro } 05 \\
\text { Admissão }\end{array}$}} & \multirow{2}{*}{\multicolumn{2}{|c|}{$\begin{array}{l}\text { Cilindro } 06 \\
\text { Admissão } \\
\end{array}$}} \\
\hline & & & & & & & & & & & & & \\
\hline & & 1 & 2 & 3 & 4 & 5 & 6 & 7 & 8 & 9 & 10 & 11 & 12 \\
\hline \multirow{2}{*}{$\begin{array}{c}\text { Ensaio de } \\
\text { durabilidade } \\
\text { dinamômetro }\end{array}$} & $\begin{array}{c}\text { Regulagem de } \\
\text { Válvula }\end{array}$ & 0,30 & 0,30 & 0,30 & 0,30 & 0,30 & 0,30 & 0,30 & 0,30 & 0,30 & 0,30 & 0,30 & 0,30 \\
\hline & $\begin{array}{c}\text { Profundidade } \\
\text { Inicial }\end{array}$ & 0,927 & 0,961 & 0,939 & 0,991 & 0,936 & 0,936 & 0,957 & 0,953 & 0,998 & 0,995 & 0,914 & 0,914 \\
\hline \multirow{2}{*}{$\begin{array}{l}\text { Ensaio de } \\
\text { durabilidade } \\
\text { veicular }\end{array}$} & $\begin{array}{c}\text { Regulagem de } \\
\text { Válvula }\end{array}$ & 0,25 & 0,30 & 0,25 & 0,25 & 0,25 & 0,20 & 0,25 & 0,20 & 0,25 & 0,25 & 0,25 & 0,25 \\
\hline & $\begin{array}{c}\text { Profundidade } \\
\text { Inicial }\end{array}$ & 0,978 & 0,924 & 0,950 & 0,989 & 0,998 & 0,950 & 0,928 & 1,000 & 1,000 & 0,995 & 0,909 & 0,998 \\
\hline
\end{tabular}

Fonte: autor da dissertação.

\subsection{Resultado do ensaio de durabilidade em dinamômetro}

5.5.1 Análises de desempenho, emissões de poluentes e nível do desgaste

Adiante estão os resultados de desempenho, conforme Figura 35, analisando ao longo do ensaio, bem como os resultados de emissões de poluentes ante e após o ensaio de durabilidade, conforme Tabela 17.

Figura 35 - Dados desempenho do motor (valores de potência ao longo do teste de durabilidade).

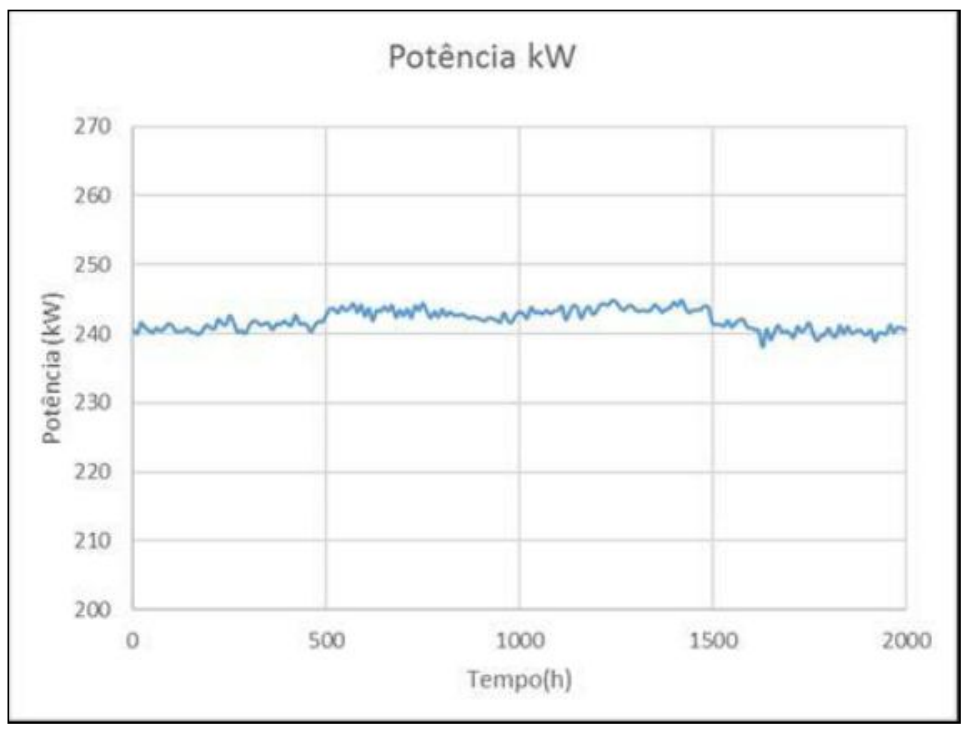

Fonte: autor da dissertação. 
Tabela 17 - Resultados comparativos de emissões de poluentes (conforme resolução número 403 CONAMA - fase7). Resultado (Ensaio 1) antes de iniciar a durabilidade e (Ensaio 2) após a durabilidade.

\begin{tabular}{c|c|c|c|c} 
Ensaio & \multicolumn{4}{|c}{ Poluentes (g/kW.h) } \\
\hline & NOx & HC & CO & Material Particulado \\
\hline Limite (Resolução) & 2,00 & 0,46 & 1,5 & 0,02 \\
\hline Ensaio 1 (antes do teste) & 1,69 & 0,01 & 0,02 & 0,018 \\
\hline Ensaio 2 (após o teste) & 1,47 & 0,01 & 0,02 & 0,016
\end{tabular}

Fonte: autor da dissertação.

Esta parte dos resultados são referentes aos requisitos de desempenho legais do motor, tanto quanto aos valores de potência ao longo do ensaio, tanto quanto a emissão de poluentes antes e após o teste de durabilidade em dinamômetro. Requisitos estes tratados pela norma ISO 1585 e pela resolução número 403 do CONAMA- PROCONVE P7.

Os resultados de desempenho foram evidenciados através da Figura 35, que mostra o resultado de potência do motor ao longo das 2000 horas de teste em dinamômetro, sendo que a grandeza se manteve praticamente estável ao logo do ensaio próximo ao valor nominal de potência do motor $(240 \mathrm{~kW})$, podendo desta maneira afirmar que nem os componentes em questão (válvula e sede de admissão), como também outros componentes que influenciam no desempenho do motor se deterioram ao ponto de influenciar na potência do motor.

As emissões de poluentes foram averiguadas antes e após o teste de durabilidade em dinamômetro e comparadas com os limites legais, sendo que os resultados praticamente não se alteraram entre o começo e o final do teste, conforme pode ser observado na Tabela 19, sendo que o resultado apresentado ao final do ensaio ainda mostra resultados ligeiramente menores que os iniciais. Obviamente neste caso podemos citar que outros componentes do motor também mantiveram um desempenho aceitável, mas com certeza o par tribológico válvula e sede de válvula apresentaram níveis de desgaste que não contribuirão com a deterioração dos níveis originais de emissão de poluentes, pois uma vez que o par apresente desgaste excessivo, este pode influenciar na perda de compressão do cilindro, tal consequência conforme verificado nas explicações de cada poluente gerado pela combustão do motor afetam negativamente os mesmos, uma vez que a 
perda de compressão do cilindro está diretamente vinculada a uma combustão homogênea.

Ao término do ensaio, o motor foi desmontado e o par tribológico válvula e sede de válvula de admissão foram analisados, sendo que as peças não poderiam apresentar trincas, quebras ou desgastes excessivos que comprometam sua funcionalidade.

$\mathrm{Na}$ Tabela 18, mostram-se os valores de profundidade de válvula, que indicam ao final do teste quanto de fato ocorreu de desgaste do conjunto válvula e sede de válvula.

Tabela 18 - Desgaste do conjunto válvula e sede de válvula de admissão após ensaio de 2000 horas, que equivale à $200000 \mathrm{~km}$.

\begin{tabular}{l|l|l|l|l|l} 
Sede & Válvula & $\begin{array}{l}\text { Profundidade } \\
\text { Inicial }(\mathbf{m m})\end{array}$ & $\begin{array}{l}\text { Profundidade } \\
\text { Final }(\mathbf{m m})\end{array}$ & Diferença $(\mathbf{m m})$ & $\begin{array}{l}\text { Desgaste }(\boldsymbol{\mu m} \\
\text { por } \mathbf{1 0 0 0 k m})\end{array}$ \\
\hline 1 & 1 & 0,927 & 0,991 & 0,064 & 0,3 \\
\hline 2 & 2 & 0,961 & 0,994 & 0,033 & 0,2 \\
\hline 3 & 3 & 0,939 & 0,985 & 0,046 & 0,2 \\
\hline 4 & 4 & 0,991 & 1,064 & 0,073 & 0,4 \\
\hline 5 & 5 & 0,936 & 0,997 & 0,061 & 0,3 \\
\hline 6 & 6 & 0,936 & 0,983 & 0,047 & 0,2 \\
\hline 7 & 7 & 0,957 & 0,998 & 0,041 & 0,2 \\
\hline 8 & 8 & 0,953 & 0,999 & 0,046 & 0,2 \\
\hline 9 & 9 & 0,998 & 1,061 & 0,063 & 0,3 \\
\hline 10 & 10 & 0,995 & 1,029 & 0,034 & 0,2 \\
\hline 11 & 11 & 0,914 & 0,988 & 0,074 & 0,4 \\
\hline
\end{tabular}

Fonte: autor da dissertação.

A Figura 36 foi gerada com o auxílio do software MINITAB versão $16 \mathrm{e}$ aplicaram-se aos resultados de desgaste da Tabela 19 a estatística de AndersonDarling (AD), que mede o quão bem os dados seguem uma distribuição específica, conforme MINITAB (2017). Caso o valor encontrado de "Valor - P" (valor da probabilidade) for menor do que o nível de significância pré-determinado de 0,1, pode-se afirmar que os dados analisados não seguem uma distribuição normal. $O$ valor AD também pode ser utilizado para determinar a normalidade dos dados, sendo que valores de $A D>1$ comprovam que os dados analisados não seguem uma 
distribuição normal. Ainda nesta Figura pode-se observar o acúmulo percentual da probabilidade de desgaste, com base na população testada.

Figura 36 - Análise gráfica da probabilidade de desgaste referente aos conjuntos de válvula e sede de válvulas do ensaio de durabilidade em dinamômetro (valores médios de 0,2583 um por $1000 \mathrm{~km}$ e desvio padrão de $0,0793 \mu \mathrm{m}$ por $1000 \mathrm{~km}$ ).

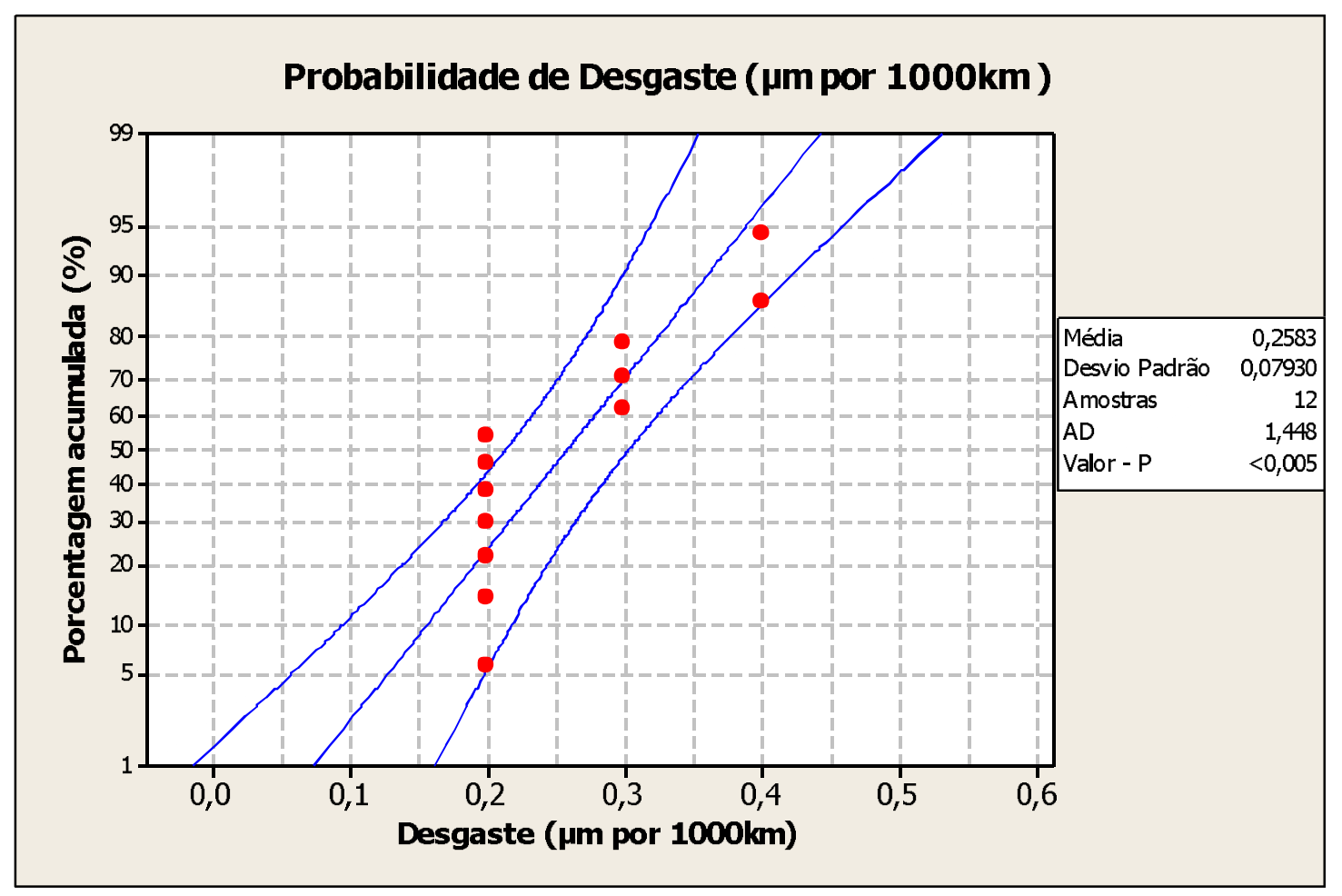

Fonte: autor da dissertação.

As discussões em torno do nível de desgaste do ensaio de durabilidade em dinamômetro serão evidenciadas após a demonstração dos resultados de durabilidade em veículo, para que haja um melhor entendimento e correlação dos resultados.

5.5.2 Análises Metalúrgicas (propriedades dos materiais)

As análises do tipo de desgaste do conjunto são evidenciadas adiante através de análise de microscopia, contudo primeiramente foi analisada a microestrutura e comparada com os requisitos de projeto, tanto para a válvula, quando para a sede de válvula. 
Para caracterizar a válvula e sede de válvula metalurgicamente foi verificada uma amostra testada e com valores de desgaste dentro do campo em que se concentra a maior população que estatisticamente, conforme Figura 36, representará a maior população no campo, com isso escolheu o par tribológico 1 e 2. A Figura 37 mostra o cabeçote de um cilindro escolhido para as análises.

Figura 37 - Fotografias mostrando o conjunto cabeçote testado (a), em detalhe as válvulas de admissão (b) e (c) as sedes de válvula, objetos de análise identificadas como "1" e "2".

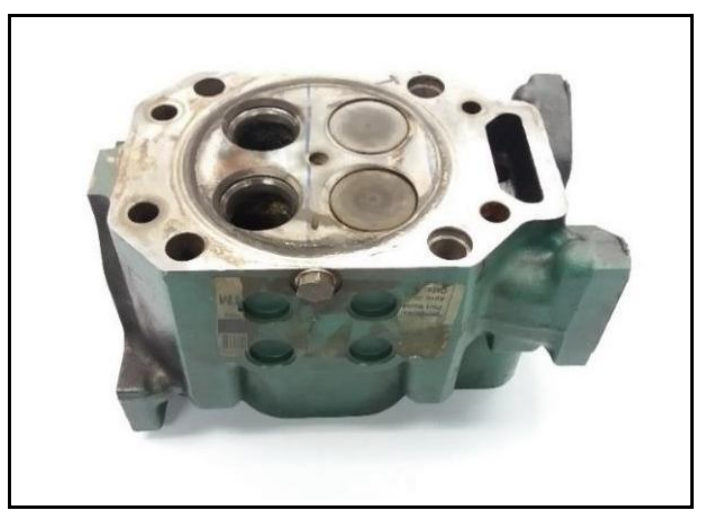

a

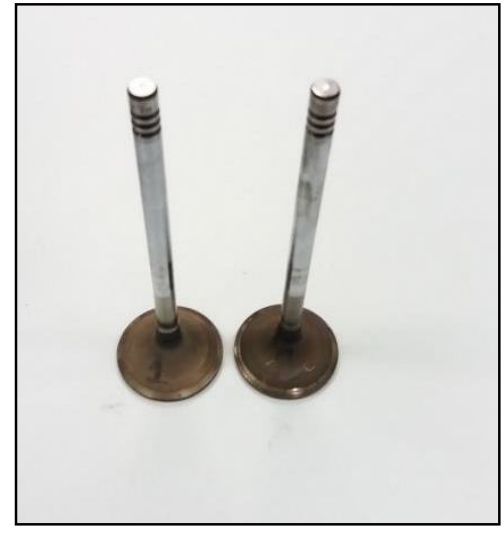

b

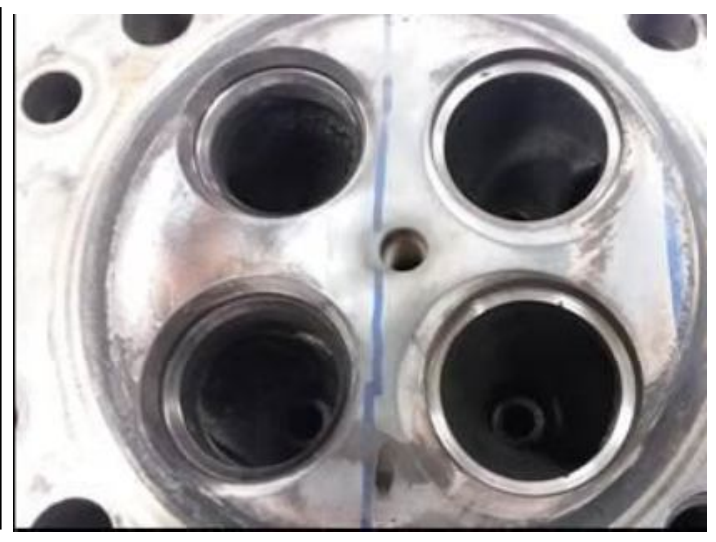

C

Fonte: autor da dissertação.

As Figuras 38 (a) e (b), mostram-se a análise de macroestrutura, da cabeça das válvulas 1 e 2 referente ao cilindro escolhido. Análises realizadas em Lupa Estereoscópica mostrando a faixa temperada das válvulas. 
Figura 38 - Macrografias em lupa estereoscópica mostrando os perfis da têmpera na região de contato entre a válvula de admissão e sede das peças 1 (a) e 2 (b) respectivamente perfis em ordem após ensaio em dinamômetro. Ataque: Marble.

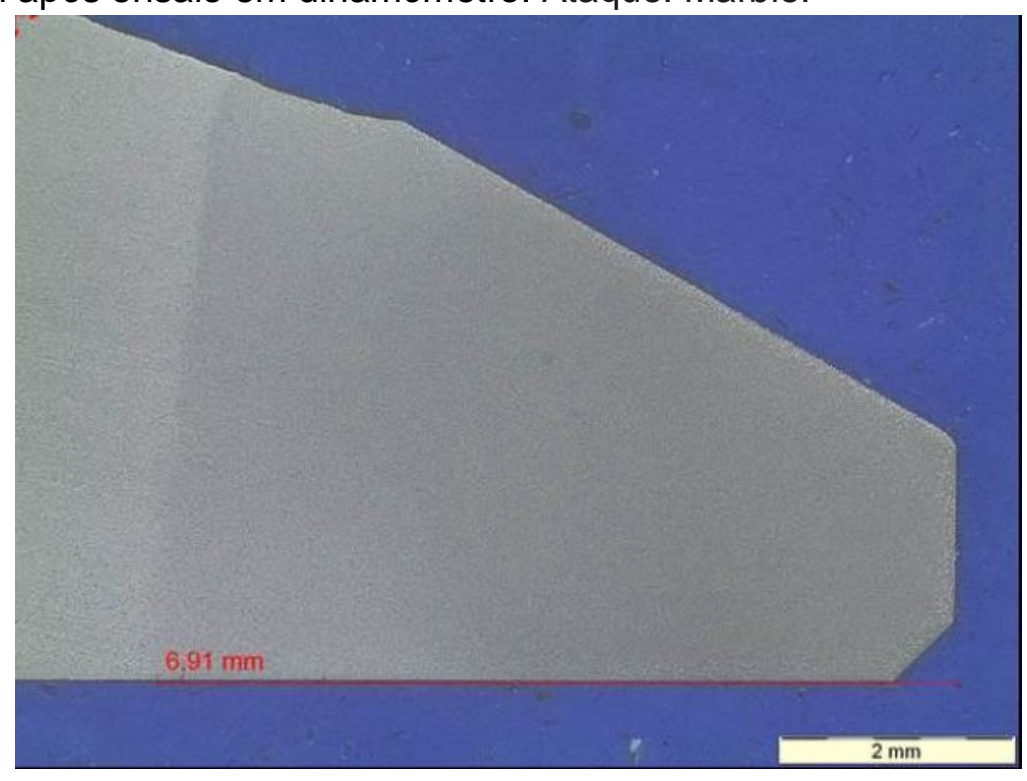

a

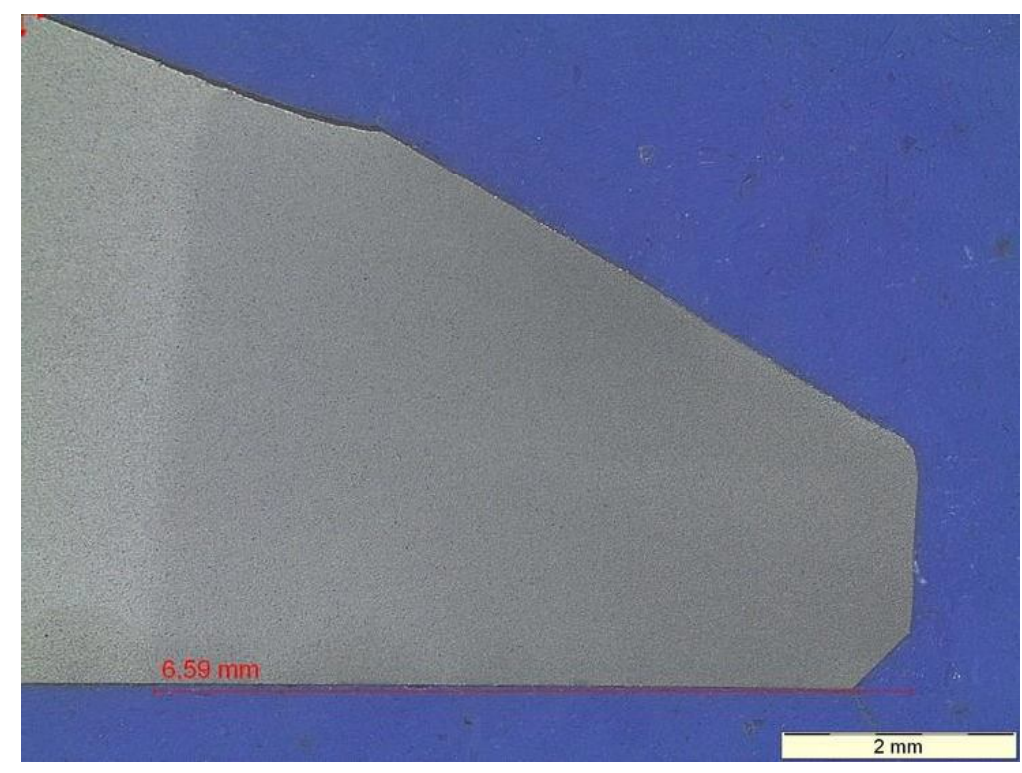

b

Fonte: autor da dissertação.

Na Figura 39, mostra-se a microestrutura da válvula na região da cabeça realizada em microscópio óptico. Na Tabela 19, mostra-se as análises descritivas metalográficas. As análises foram realizadas em ambiente de ensaio com temperatura $21^{\circ} \mathrm{C}$ e umidade $57 \%$. 
Figura 39 - Micrografia em microscópio óptico mostrando a estrutura da matriz na região da cabeça da válvula- martensitica com carbonetos bem distribuídos após ensaio em dinamômetro. Ataque: Água régia.

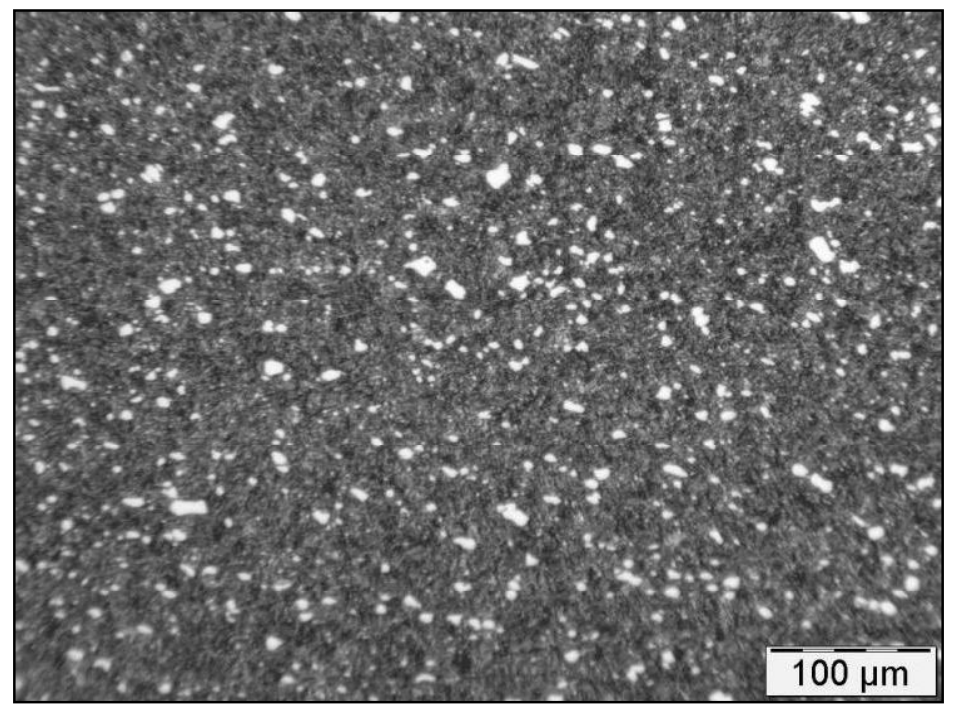

Fonte: autor da dissertação.

Tabela 19 - Resultados da análise metalográfica das válvulas de admissão após ensaio em dinamômetro.

\begin{tabular}{l|l|l}
\hline Item & Especificado & Encontrado \\
\hline 1 & Estrutura da matriz: Beneficiada & Beneficiada \\
\hline 2 & Carbonetos: Distribuídos Uniformemente & $\begin{array}{l}\text { Distribuídos } \\
\text { uniformemente }\end{array}$ \\
\hline 3 & Descarbonetação: Ausente & Ausente \\
\hline 4 & Espessura da camada de cromo: 3 a 11 $\mu \mathrm{m}$ & $6 \mu \mathrm{m}$ \\
\hline 5 & Trincas e dobras: Ausentes & Ausentes \\
\hline 6 & Profundidade da têmpera por indução na ponta: 14 a 21 mm & $20,2 \mathrm{~mm}$ \\
\hline 7 & $\begin{array}{l}\text { Profundidade da têmpera por indução na região de } \\
\text { assentamento da sede - (Rht 385 HV1) - Posição A: 1,6 mm }\end{array}$ & \\
\hline
\end{tabular}

Fonte: autor da dissertação.

A análise química (Tabela 20) foi realizada em ambiente de ensaio de temperatura $21^{\circ} \mathrm{C}$ e umidade: $57 \%$, através de espectrômetro de emissão óptica. 
Tabela 20 - Resultados da análise química da válvula após ensaio em dinamômetro.

\begin{tabular}{|c|c|c|c|c|c|c|c|c|}
\hline \multicolumn{9}{|c|}{ COMPOSIÇÃO QUÍMICA (\% EM MASSA) - Amostra } \\
\hline \multirow[t]{2}{*}{ Item } & 1 & 2 & 3 & 4 & 5 & 6 & 7 & 8 \\
\hline & C & $\mathrm{Si}$ & $\mathrm{Mn}$ & $P$ & $S$ & $\mathrm{Cr}$ & Mo & $\mathrm{V}$ \\
\hline Especificação & $\begin{array}{l}0,80 \\
a \\
0,90\end{array}$ & $\begin{array}{l}1,00 \\
\max \end{array}$ & $\begin{array}{l}1,50 \\
\max \end{array}$ & $\begin{array}{l}0,04 \\
\max \end{array}$ & $\begin{array}{l}0,03 \\
\max \end{array}$ & $\begin{array}{l}16,50 \\
a \\
18,50\end{array}$ & $\begin{array}{l}2,00 \\
a \\
2,50\end{array}$ & $\begin{array}{l}0,30 \\
a \\
0,60\end{array}$ \\
\hline Valores & 0,83 & 0,28 & 0,96 & 0,016 & 0,005 & 16,65 & 2,32 & 0,35 \\
\hline
\end{tabular}

Fonte: autor da dissertação.

Os ensaios físicos foram realizados em ambiente de ensaio com temperatura $21^{\circ} \mathrm{C}$ e umidade $57 \%$, conforme Tabela 21 .

Tabela 21 - Resultados dos ensaios físicos da válvula após ensaio em dinamômetro.

\begin{tabular}{l|l|l}
\hline Item & Especificado & Encontrado \\
\hline 1 & Dureza na Haste / Cabeça: 35 a 42 HRC & $\begin{array}{l}\text { Peça 1: 38,2 a 38,6 HRC } \\
\text { Peça 2: 38,2 a 38,3 HRC }\end{array}$ \\
\hline 2 & $\begin{array}{l}\text { Dureza na região de assentamento da } \\
\text { sede: 45 HRC mínimo }\end{array}$ & $\begin{array}{l}\text { Peça 1: } 52,5 \text { a 53,0 HRC } \\
\text { Peça 2: } 51,7 \text { a 53,0 HRC }\end{array}$ \\
\hline
\end{tabular}

Fonte: autor da dissertação.

Assim como conduzido para a válvula de admissão a caracterização metalúrgica da sede válvulas de admissão foi conduzida no mesmo cabeçote anteriormente identificado na Figura 36 (c).

Nas Figuras 40 e 41, mostram-se a microestrutura da sede de válvula realizada em microscópio óptico, bem como na Tabela 22, as análises metalográficas descritivas. As análises foram realizadas em ambiente de ensaio com temperatura $21^{\circ} \mathrm{C}$ e umidade $57 \%$. 
Figura 40 - Micrografia em microscópio óptico da sede de válvula, mostrando a distribuição homogênea dos poros na matriz - poros cobertos com cobre, após ensaio em dinamômetro. Ataque: sem ataque.

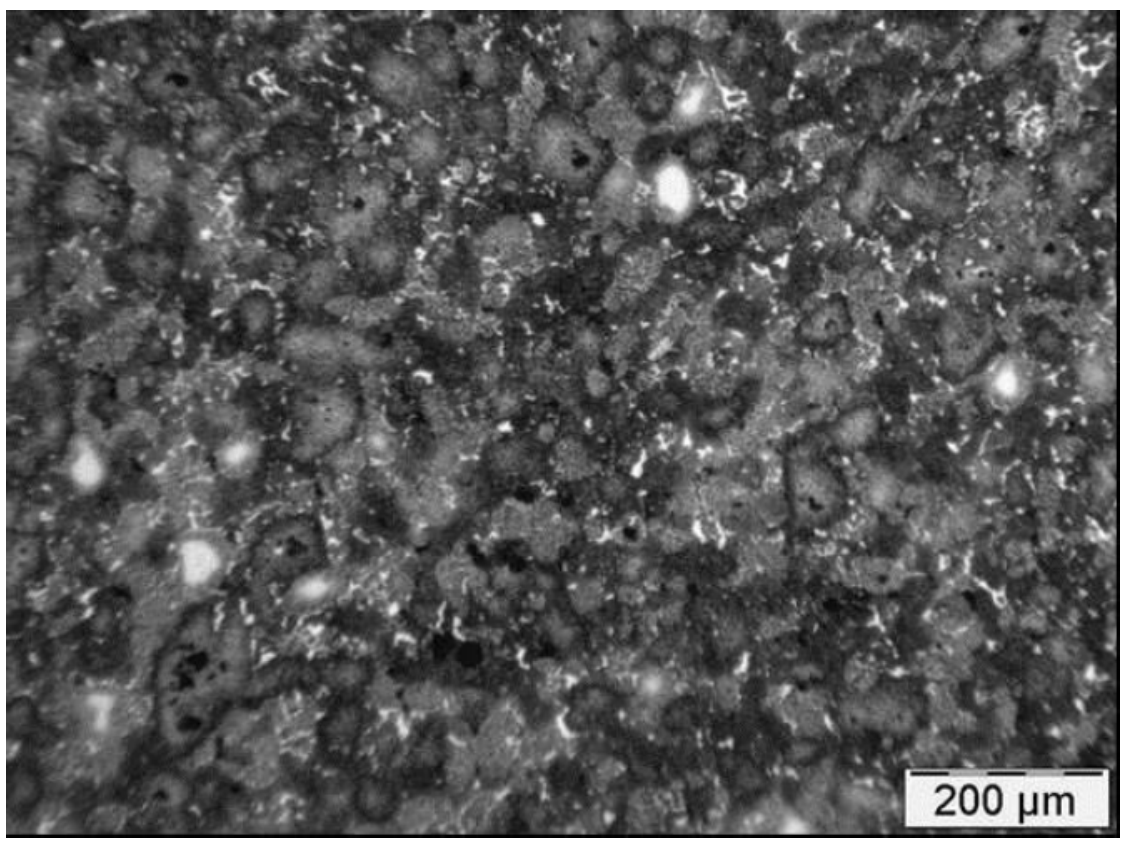

Fonte: autor da dissertação.

Figura 41 - Micrografia em microscópio óptico da sede de válvula, mostrando a estrutura da matriz - carbonetos distribuídos fina e uniformemente, e uma fase intermetálica em uma matriz martensítica, após ensaio em dinamômetro. Ataque: Nital 3\%.

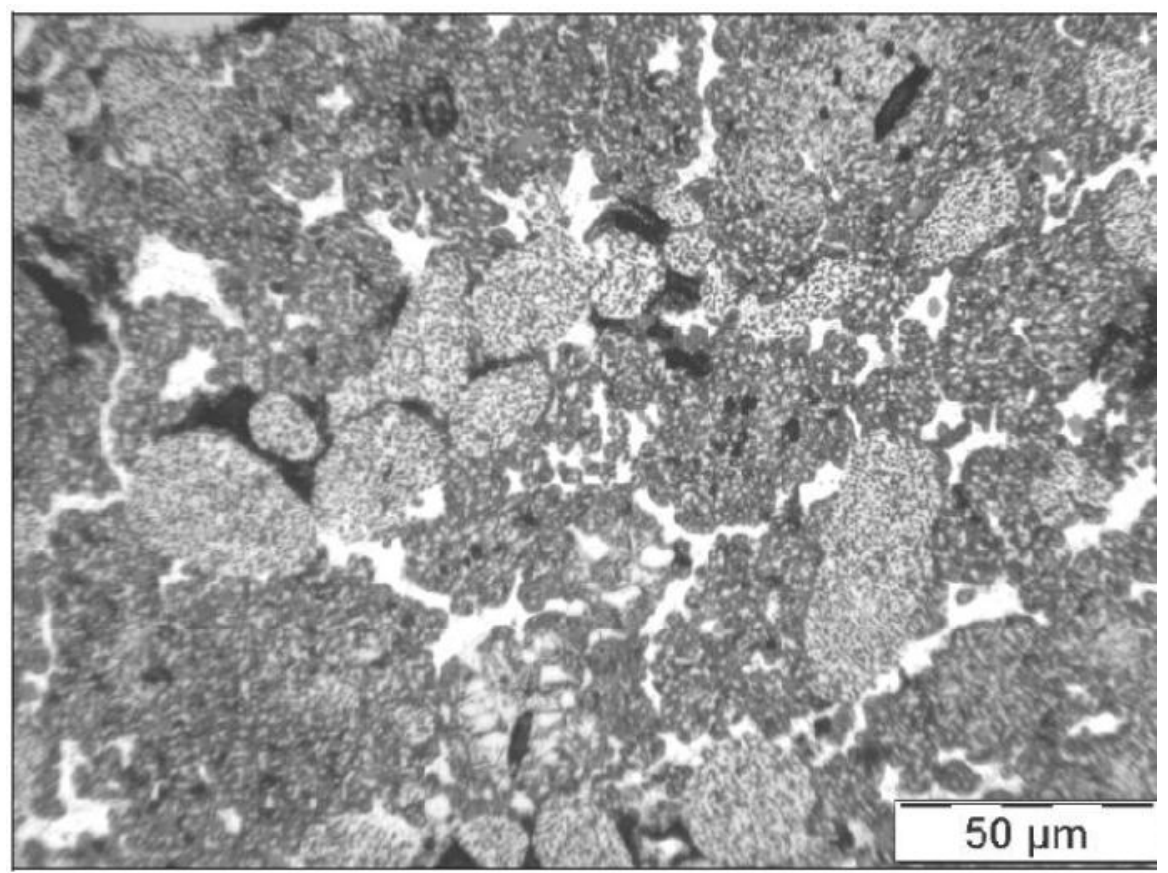

Fonte: autor da dissertação. 
Tabela 22 - Resultados da análise metalográfica da sede de válvula, após ensaio em dinamômetro.

\begin{tabular}{|c|c|c|}
\hline Item & Especificado & Encontrado \\
\hline 1 & Processo de fabricação: Sinterizada & Sinterizada \\
\hline 2 & Estrutura da matriz: Martensítica & Martensita revenida \\
\hline 3 & Carbonetos: Distribuição uniforme & $\begin{array}{l}\text { Finos e distribuídos } \\
\text { uniforme em uma fase } \\
\text { intermediária }\end{array}$ \\
\hline 4 & Perlita: Ausente & Ausente \\
\hline 5 & Compostos intermetálicos: Presentes & Presentes \\
\hline 6 & Poros: Cobertos com cobre & Em ordem \\
\hline 7 & $\begin{array}{l}\text { Defeitos superficiais na região compreendida como P1 e P4 } \\
\text { (assento): Ausentes }\end{array}$ & Ausentes \\
\hline 8 & $\begin{array}{l}\text { Defeitos superficiais nas demais regiões: Máximo } 5 \text { defeitos } \\
\text { por peça, com diâmetro e/ou profundidade inferior a 0,8 mm } \\
\text { e equidistantes entre si, no mínimo, } 3,2 \mathrm{~mm}\end{array}$ & Em ordem \\
\hline 9 & Trincas e/ou junta fria: Ausente & Ausente \\
\hline
\end{tabular}

Fonte: autor da dissertação.

$\mathrm{Na}$ Tabela 23, mostram-se os resultados de composição química através de espectrômetro de emissão óptica. Os ensaios físicos de dureza em três pontos na superfície de contato com a sede, sendo que os resultados mostram uma dureza de 50,5 até 52,9 HRC (faixa encontrada em ambas as sedes de válvulas) e o especificado é 45 a $55 \mathrm{HRC}$ 
Tabela 23 - Resultados da análise química da sede de válvula, após ensaio em dinamômetro.

COMPOSIÇÃO QUÍMICA (\% EM MASSA) - Amostra

\begin{tabular}{l|l|l|l|l|l|l|l|l|l|l|l}
\hline Item & 1 & 2 & 3 & 4 & 5 & 6 & 7 & 8 & 9 & 10 & 11 \\
\hline Especificação & $\mathrm{C}$ & $\mathrm{Co}$ & $\mathrm{Mo}$ & $\mathrm{W}$ & $\mathrm{V}$ & $\mathrm{Cr}$ & $\mathrm{Si}$ & $\mathrm{Mn}$ & $\mathrm{S}$ & $\mathrm{Cu}$ & $\mathrm{Fe}$ \\
\hline Mínimo & 0,80 & 15,00 & 9,00 & 2,50 & 1,30 & 3,50 & 0,50 & 0,30 & 0,15 & 10,00 & Restante \\
\hline Máximo & 1,30 & 22,00 & 14,00 & 4,50 & 2,30 & 5,50 & 2,00 & 1,50 & 0,75 & 20,00 & \\
\hline $\begin{array}{l}\text { Valores } \\
\text { encontrados }\end{array}$ & 1,08 & 17,35 & 12,86 & 4,33 & 1,86 & 5,36 & 0,78 & 0,73 & 0,58 & 16,16 & Restante \\
\end{tabular}

Fonte: autor da dissertação.

5.5.3 Análise do tipo de desgaste (contato válvula e sede de válvula)

Através do microscópio eletrônico de varredura foi analisado o desgaste na superfície de contato da válvula e da sede de válvula utilizando imagens a partir de elétrons retro espalhados (BSE) e elétrons secundários (SEI) e espectroscopia por energia dispersiva (EDS). Na sequência, as Figuras 42, 43, 44 e 45 mostram detalhes do tipo de desgaste. 
Figura 42 - Análise através de espectroscopia por energia dispersiva (EDS) comparativa entre superfície de assento de válvula (a) e superfície da sede de válvula (b). Análise EDS realizada em corte transversal. Nota-se em (b), círculo vermelho, alta concentração de cobre originário da sede de válvula, após ensaio em dinamômetro.
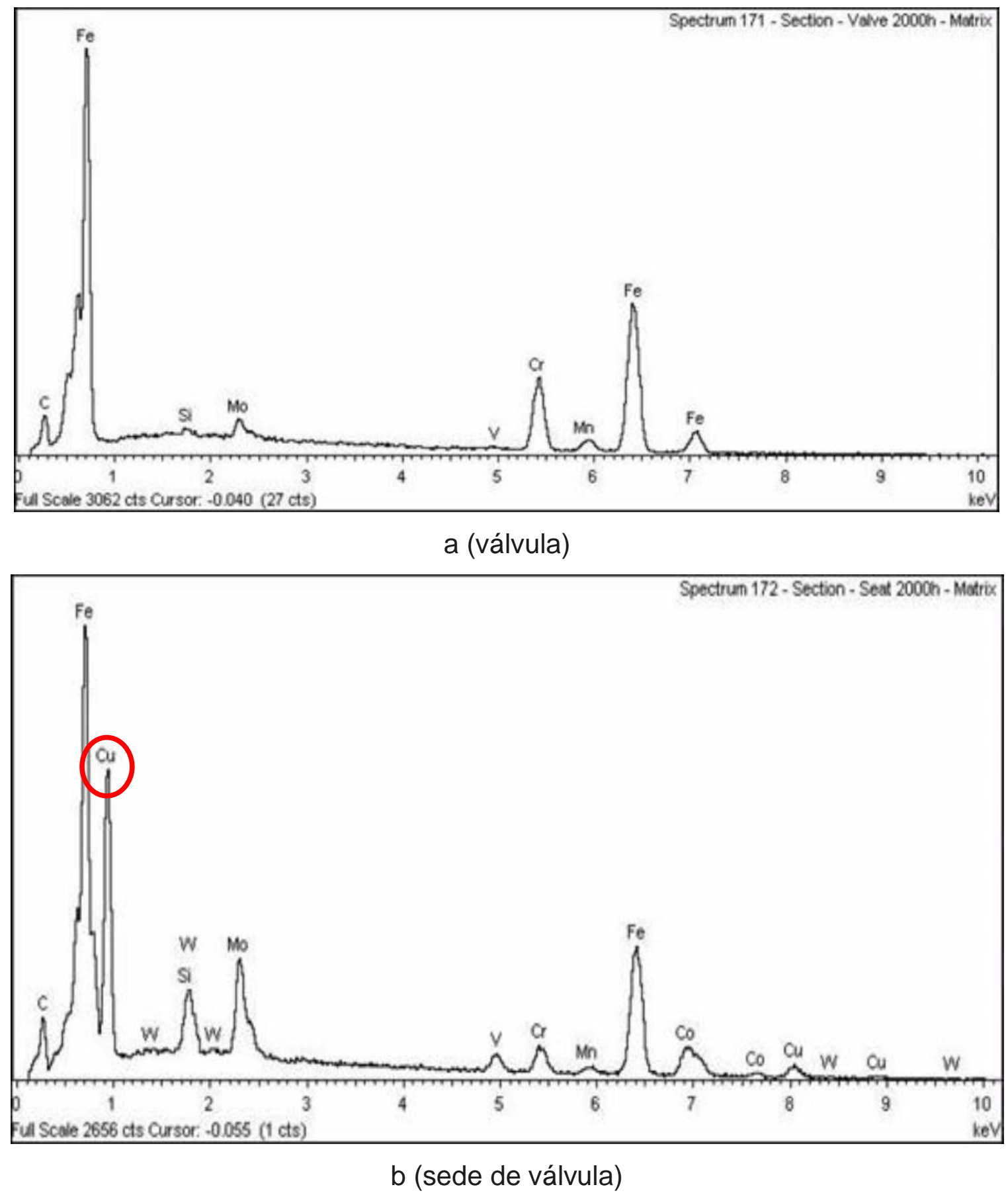

Fonte: autor da dissertação. 
Figura 43 - A análise de superfície por MEV realizada no contato da válvula com a sede de válvula, que apontou características de desgaste Adesivo. O desgaste do adesivo está relacionado com tensões de cisalhamento elevadas causadas pela fricção. Observou-se regiões cinzentas (c), com presença significativa do elemento cobre, vide Figura 44, material transferido da sede de válvula, após ensaio em dinamômetro.

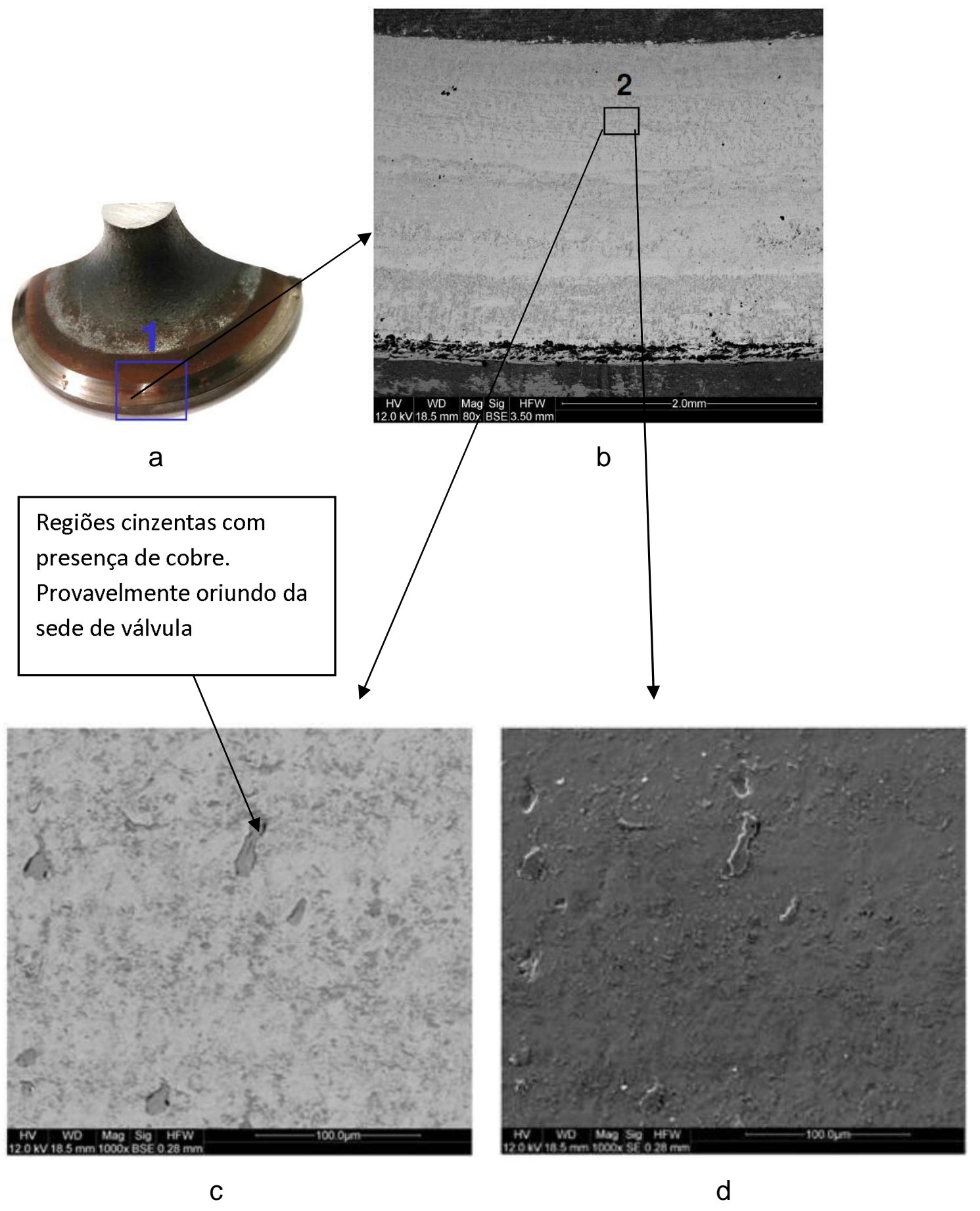

Fonte: autor da dissertação. 
Figura 44 - Análise em MEV / EDS mostrando a presença do elemento cobre na válvula de admissão, após ensaio em dinamômetro.
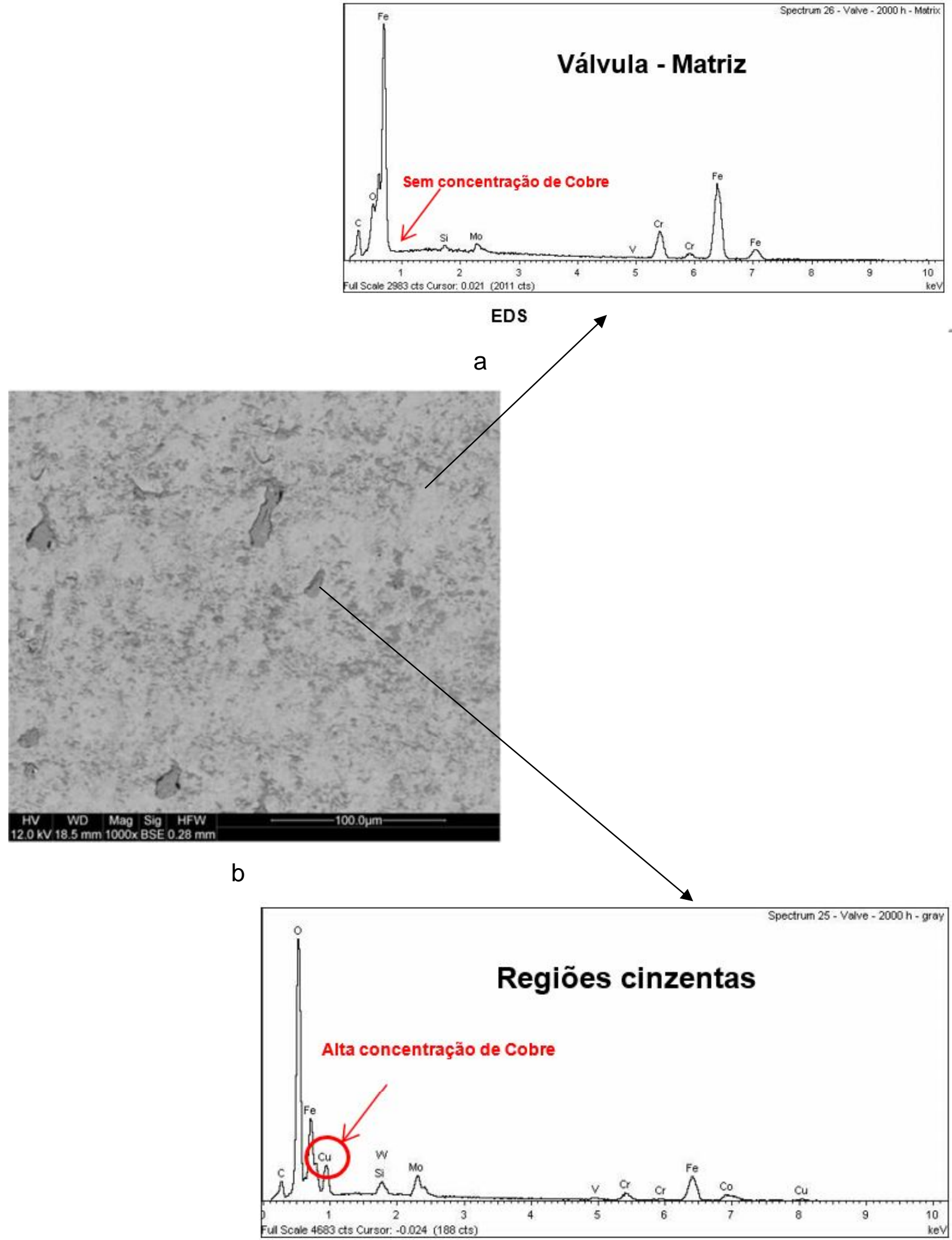

EDS

C

Fonte: autor da dissertação. 
Figura 45 - A análise de superfície por MEV realizada sobre a superfície de contato da sede de válvula mostrou deformação plástica e pequenos destacamentos de material na superfície, após ensaio em dinamômetro.

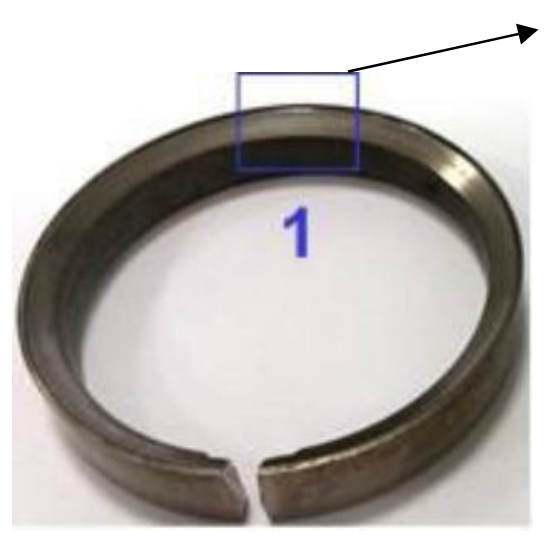

a

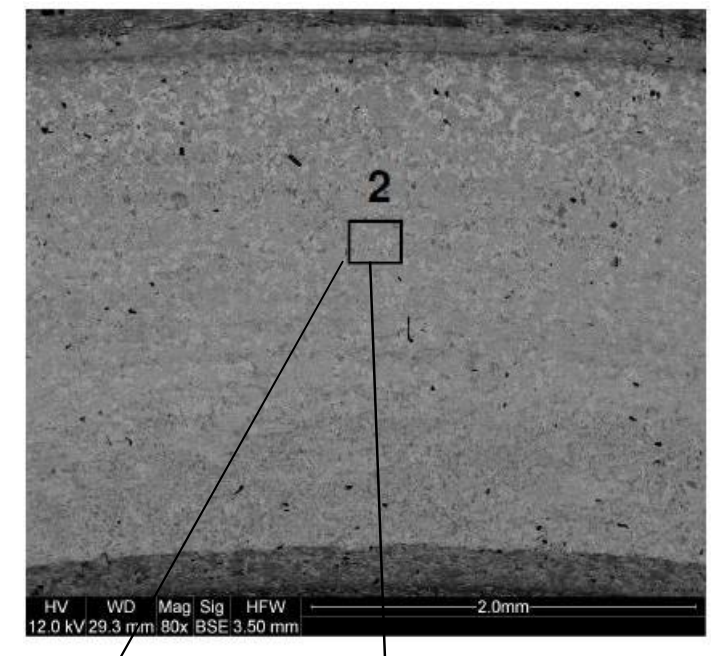

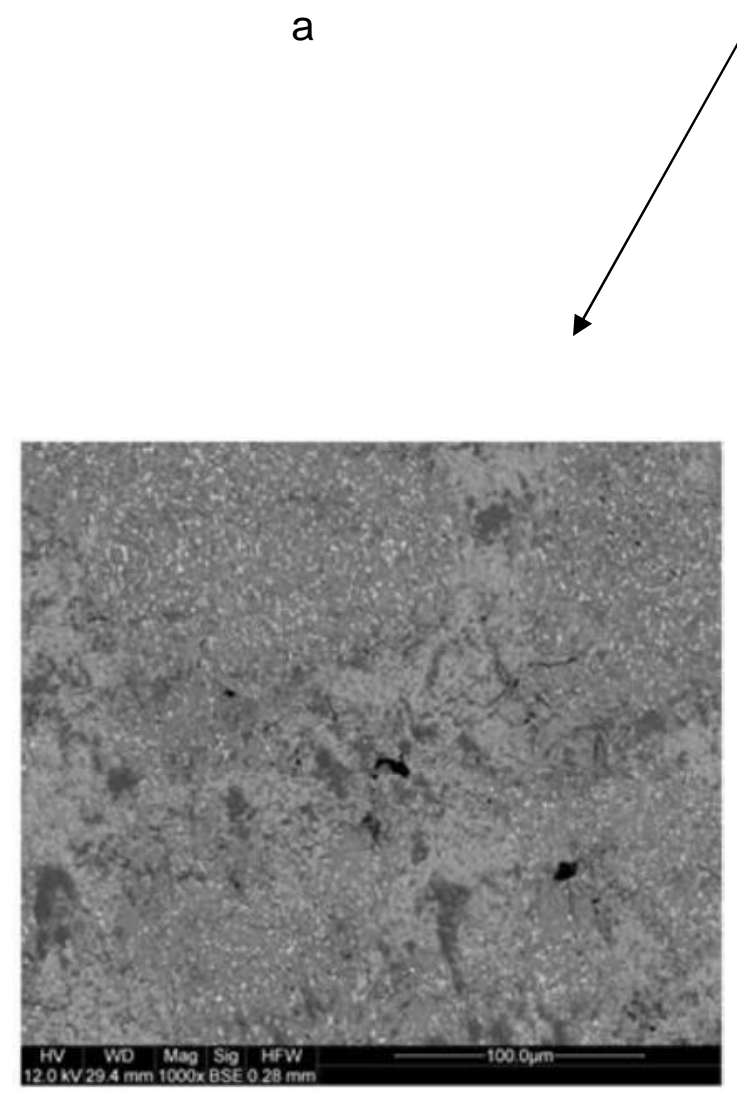

C

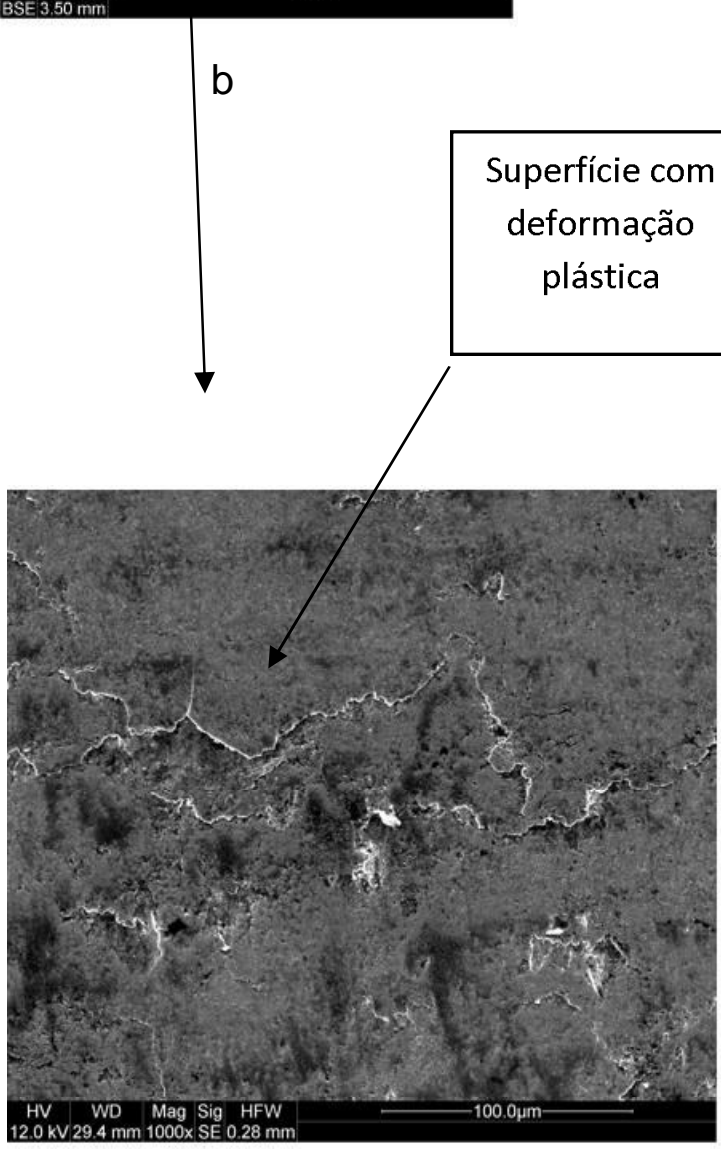

d

Fonte: autor da dissertação. 


\subsection{Resultado do ensaio de durabilidade veicular}

\subsubsection{Análise do nível do desgaste}

Os valores de folga foram controlados durante todo o ensaio de durabilidade veicular, pois é um parâmetro que sinaliza se está ocorrendo algum desgaste excessivo durante 0 teste, caso fosse observado que as folgas diminuíssem durante o ensaio. $\mathrm{Na}$ Tabela 24 , mostram-se os valores de folga durante o teste. Na Tabela 25, mostram-se os resultados de desgaste do conjunto válvula e sede de válvula de admissão.

Tabela 24 - Valores de folga de válvula durante o ensaio de durabilidade veicular, após resfriamento do motor.

\begin{tabular}{|c|c|c|c|c|c|c|c|c|c|c|c|c|}
\hline \multirow{3}{*}{$\begin{array}{l}\text { Quilometragem } \\
\text { Analisada }\end{array}$} & \multicolumn{2}{|c|}{ Cilindro 01} & \multicolumn{2}{|c|}{ Cilindro 02} & \multicolumn{2}{|c|}{ Cilindro 03} & \multicolumn{2}{|c|}{ Cilindro 04} & \multicolumn{2}{|c|}{ Cilindro 05} & \multicolumn{2}{|c|}{ Cilindro 06} \\
\hline & \multicolumn{2}{|c|}{ Admissão } & \multicolumn{2}{|c|}{ Admissão } & \multicolumn{2}{|c|}{ Admissão } & \multicolumn{2}{|c|}{ Admissão } & \multicolumn{2}{|c|}{ Admissão } & \multicolumn{2}{|c|}{ Admissão } \\
\hline & 1 & 2 & 3 & 4 & 5 & 6 & 7 & 8 & 9 & 10 & 11 & 12 \\
\hline $0 \mathrm{~km}$ & 0,25 & 0,30 & 0,25 & 0,25 & 0,25 & 0,20 & 0,25 & 0,20 & 0,25 & 0,25 & 0,25 & 0,25 \\
\hline $12.000 \mathrm{~km}$ & 0,35 & 0,30 & 0,35 & 0,30 & 0,35 & 0,30 & 0,30 & 0,25 & 0,35 & 0,30 & 0,30 & 0,25 \\
\hline $37.500 \mathrm{~km}$ & 0,35 & 0,35 & 0,35 & 0,35 & 0,35 & 0,35 & 0,35 & 0,35 & 0,35 & 0,35 & 0,40 & 0,40 \\
\hline $47.500 \mathrm{~km}$ & 0,40 & 0,35 & 0,40 & 0,40 & 0,40 & 0,40 & 0,40 & 0,40 & 0,40 & 0,40 & 0,40 & 0,40 \\
\hline $71.500 \mathrm{~km}$ & 0,40 & 0,40 & 0,40 & 0,40 & 0,40 & 0,40 & 0,40 & 0,40 & 0,40 & 0,40 & 0,40 & 0,40 \\
\hline $91.300 \mathrm{~km}$ & 0,40 & 0,40 & 0,40 & 0,40 & 0,35 & 0,35 & 0,35 & 0,35 & 0,35 & 0,35 & 0,40 & 0,40 \\
\hline $100.000 \mathrm{~km}$ & 0,40 & 0,40 & 0,40 & 0,40 & 0,35 & 0,35 & 0,35 & 0,35 & 0,35 & 0,35 & 0,40 & 0,40 \\
\hline
\end{tabular}

Fonte: autor da dissertação.

Tabela 25 - Desgaste do conjunto válvula e sede de válvula de admissão após ensaio de durabilidade veicular.

\begin{tabular}{c|c|c|c|c|c} 
Sede & Válvula & $\begin{array}{c}\text { Profundidade } \\
\text { Inicial }(\mathbf{m m})\end{array}$ & $\begin{array}{c}\text { Profundidade } \\
\text { Final }(\mathbf{m m})\end{array}$ & Diferença $(\mathbf{m m})$ & $\begin{array}{c}\text { Desgaste }(\boldsymbol{\mu m} \\
\text { por } \mathbf{1 0 0 0} \mathbf{k m})\end{array}$ \\
\hline 1 & 1 & 0,978 & 0,995 & 0,017 & 0,2 \\
\hline 2 & 2 & 0,924 & 0,958 & 0,034 & 0,3 \\
\hline 3 & 3 & 0,950 & 0,971 & 0,021 & 0,2 \\
\hline 4 & 4 & 0,989 & 1,024 & 0,035 & 0,4 \\
\hline 6 & 5 & 0,998 & 1,030 & 0,032 & 0,3 \\
\hline 7 & 6 & 0,950 & 0,975 & 0,025 & 0,3 \\
\hline 8 & 7 & 0,928 & 0,945 & 0,017 & 0,2 \\
\hline 10 & 8 & 1,000 & 1,032 & 0,032 & 0,3 \\
\hline 11 & 9 & 1,000 & 1,045 & 0,045 & 0,4 \\
\hline 12 & 10 & 0,995 & 1,024 & 0,029 & 0,3 \\
\hline
\end{tabular}

Fonte: autor da dissertação. 
A Figura 46 foi gerada com o auxílio do software MINITAB versão 16 e aplicaram-se aos resultados de desgaste da Tabela 25 a estatística $A D$, que mede 0 quão bem os dados seguem uma distribuição específica, conforme MINITAB (2017). Caso o valor encontrado de "Valor - P" (valor da probabilidade) for menor do que 0 nível de significância pré-determinado de 0,1 , pode-se afirmar que os dados analisados não seguem uma distribuição normal. Ainda nesta Figura pode-se observar o acumulo percentual da probabilidade de desgaste, com base na população testada.

Figura 46 - Análise gráfica da probabilidade de desgaste referente aos conjuntos de válvula e sede de válvulas do ensaio de durabilidade veicular (valores médios de 0,2917 $\mu \mathrm{m}$ por $1000 \mathrm{~km}$ e desvio padrão de $0,0793 \mu \mathrm{m}$ por $1000 \mathrm{~km}$ ).

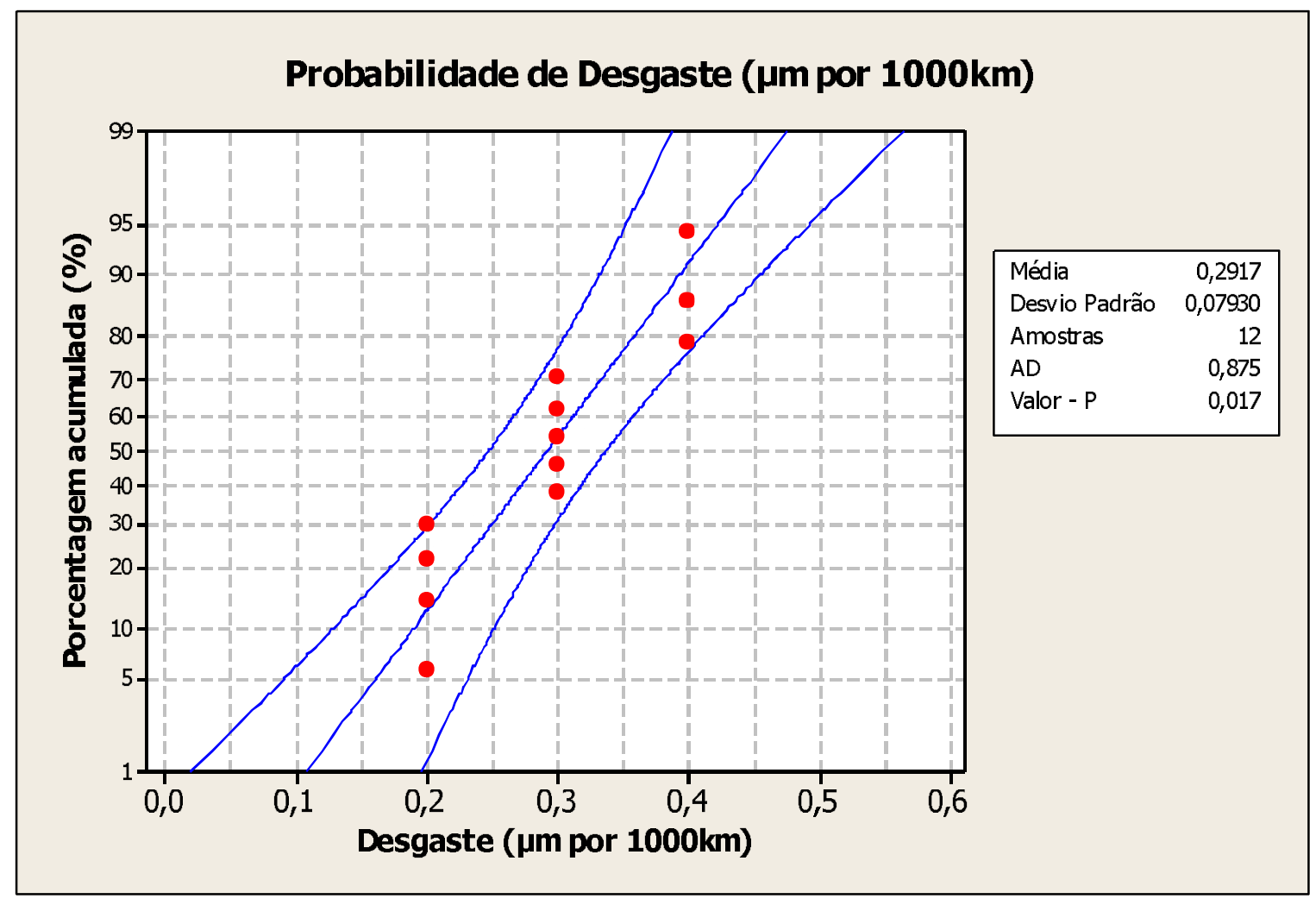

Fonte: autor da dissertação.

O desgaste é uma ocorrência natural de corpos em movimento. Importante é conhecer se o nível de desgaste influencia na função de um determinado componente. O par tribológico analisado mostrou não afetar o desempenho do motor quanto a requisitos legais, conforme já discutido anteriormente. Contudo ainda resta analisar se o nível de desgaste influenciou nos 
requisitos de vida e manutenção do motor. Para isso as Tabelas 18 e 25 e as Figuras 36 e 46 auxiliaram na análise deste item.

A Tabela 2 deste trabalho mostra o nível de desgaste pelo tipo de combustível utilizado pelo motor. Os motores destinados para o desenvolvimento deste trabalho foram ciclo diesel, para tanto a taxa desgaste no par tribológico válvula e sede de válvula observada para estes motores vão de $1 \mu \mathrm{m}$ até $5 \mu \mathrm{m}$ a cada $1000 \mathrm{~km}$ rodados, segundo BASSHUYSEN e SCHAFER (2004). Os resultados obtidos em ambos ensaios realizados (dinamômetro e campo) mostraram valores entre $0,2 \mu \mathrm{m}$ até $0,4 \mu \mathrm{m}$ a cada $1000 \mathrm{~km}$ rodados, ou seja, expressivamente abaixo do menor valor indicado nesta literatura.

Os valores de desgaste quando correlacionados a vida do produto, tomando como referência o motor testado, sendo que a vida B10, ou seja, até $10 \%$ de falhas no intervalo requerido, que é de $750000 \mathrm{~km}$, mostra que ao atingir esta quilometragem os conjuntos testados em ambos motores de durabilidade apresentariam desgaste máximo de 0,3 $\mathrm{mm}$. Quando fazemos este mesmo cálculo utilizando o menor valor citado em literatura que é $1 \mu \mathrm{m}$ a cada $1000 \mathrm{~km}$, conforme BASSHUYSEN e SCHAFER (2004) teríamos um desgaste de $0,75 \mathrm{~mm}$ do conjunto válvula e sede de válvula.

Nas Figuras 47 (a) e (b), apresentam-se o perfil de desgaste de um par tribológico válvula e sede de válvula do ensaio de durabilidade veicular, sendo evidenciado o nível de desgaste individualmente de cada componente. Pelo observado, o desgaste é compartilhado entre válvula e sede de válvula, ou seja, é dividido entre os componentes, sendo esta informação justificada pela compatibilidade de dureza entre os materiais. 
Figura 47 - Perfil de desgaste mostrando em detalhe a região de contato da válvula (a) e a região de contato com a sede de válvula (b). Verificação realizada em perfilômetro Pherthometer MAHR.

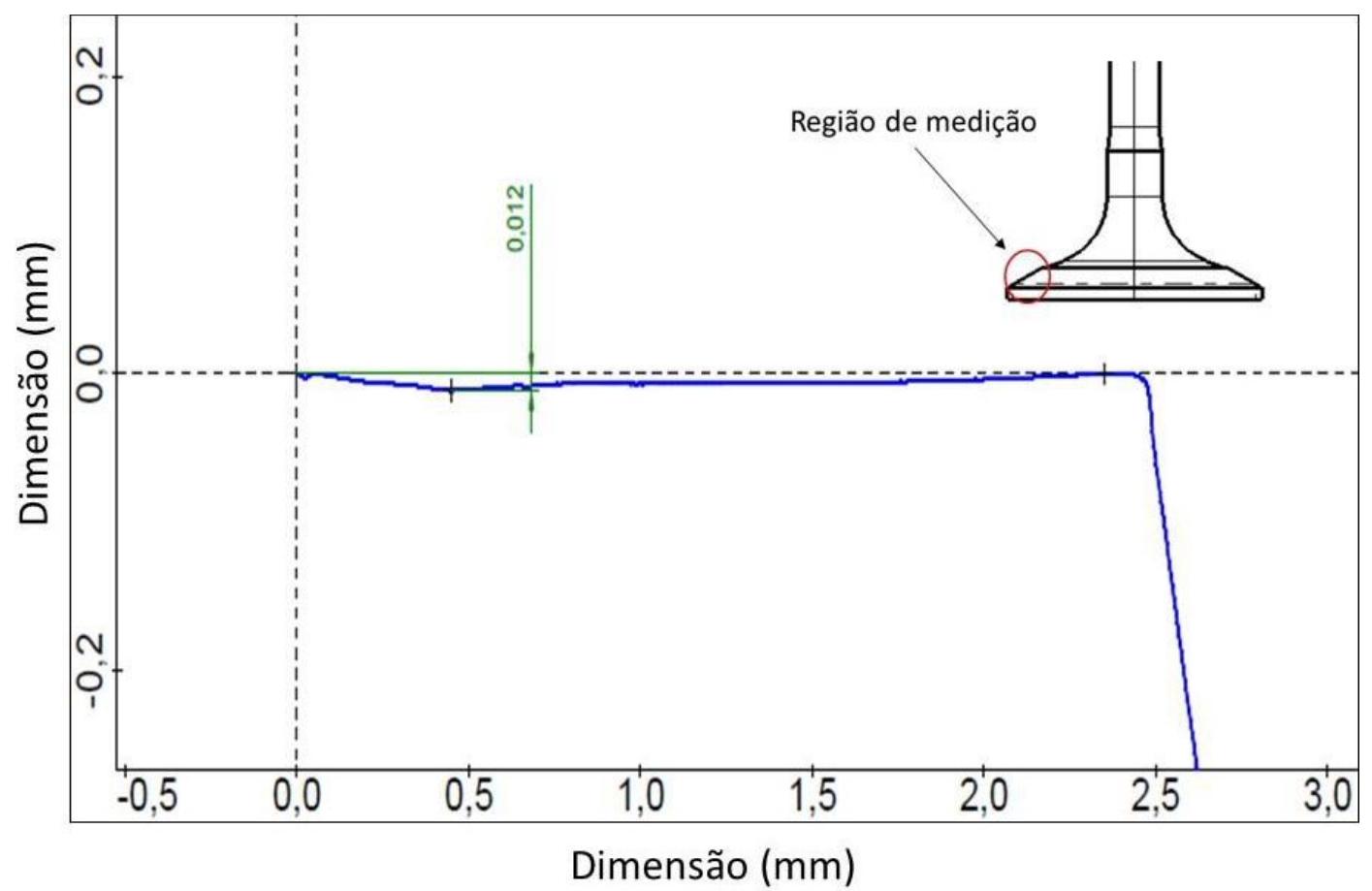

a

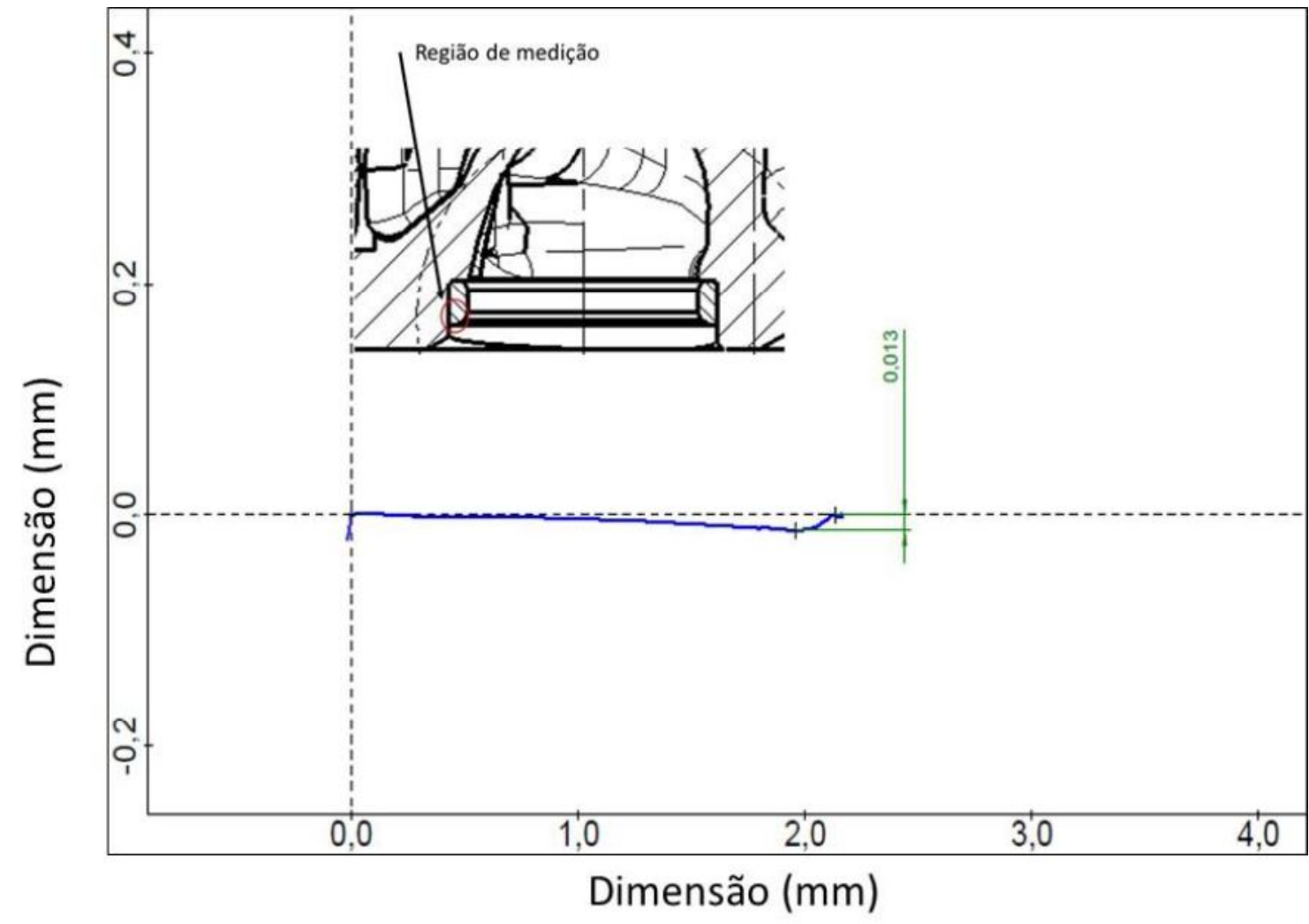

Fonte: autor da dissertação. 
Os resultados do nível de desgaste também mostram uma variação de valores $0,2 \mu \mathrm{m}$ até $0,4 \mu \mathrm{m}$ a cada $1000 \mathrm{~km}$ rodados. A variação pode ser justificada por diversos aspectos relacionados ao design, como variações dimensionais no ângulo de contato entre a válvula e a sede de válvula, conforme observado nas simulações realizadas (vide Figura 29), o ângulo de contato influencia diretamente na deflexão da válvula como também na pressão de contato. Outros aspectos relacionados ao batimento entre a sede de válvula e a guia de válvula, batimento entre a cabeça da válvula e a haste da válvula também podem influenciar no desgaste do conjunto. Aspectos relacionados a lubrificação oriunda do corrimento de óleo lubrificante existente entre válvula e o retentor de válvula que afeta o desgaste do par tribológico válvula e sede de válvula. Ainda podem-se citar diferenças entre carregamentos térmicos e mecânicos oriundos de diferenças de pressões de combustão entre cilindros podendo ocasionar em diferenças de desgastes de pares tribológicos de um mesmo motor. Contudo estes fatores citados devem ser analisados em conjunto para entendimento das diferenças nos desgastes encontrados.

As Figuras 36 e 46, mostram as diferenças de desgaste entre as peças testadas, como também a probabilidade que pode ocorrer cada nível de desgaste, sendo que para $95 \%$ de confiabilidade teremos praticamente $80 \%$ da população dos pares tribológicos válvula e sede de válvula de admissão com desgaste entre 0,2 e $0,3 \mu \mathrm{m}$ por $1000 \mathrm{~km}$. A Figura 50 concentra os resultados de desgaste dos dois ensaios realizados, ou seja, da durabilidade em dinamômetro e veicular. A Figura foi gerada com o auxílio do software MINITAB versão 16 e aplicou-se aos resultados de desgaste da Tabela 18 e 25 a estatística de Anderson-Darling (AD), que mede o quão bem os dados seguem uma distribuição específica. Caso o valor encontrado de "Valor - P" for menor do que o nível de significância pré-determinado de 0,1 , pode-se afirmar que os dados analisados não seguem uma distribuição normal. normal. $O$ valor $A D$ também pode ser utilizado para determinar a normalidade dos dados, sendo que valores de $A D>1$ comprovam que os dados analisados não seguem uma distribuição normal. Ainda nesta Figura pode-se observar o acumulo percentual da probabilidade de desgaste, com base na população total testada. 
Figura 48 - Análise gráfica da probabilidade de desgaste referente aos conjuntos de válvula e sede de válvulas dos ensaios de durabilidade em dinamômetro e veicular (valores médios de $0,275 \mu \mathrm{m}$ por $1000 \mathrm{~km}$ e desvio padrão de $0,0794 \mu \mathrm{m}$ por $1000 \mathrm{~km}$ ).

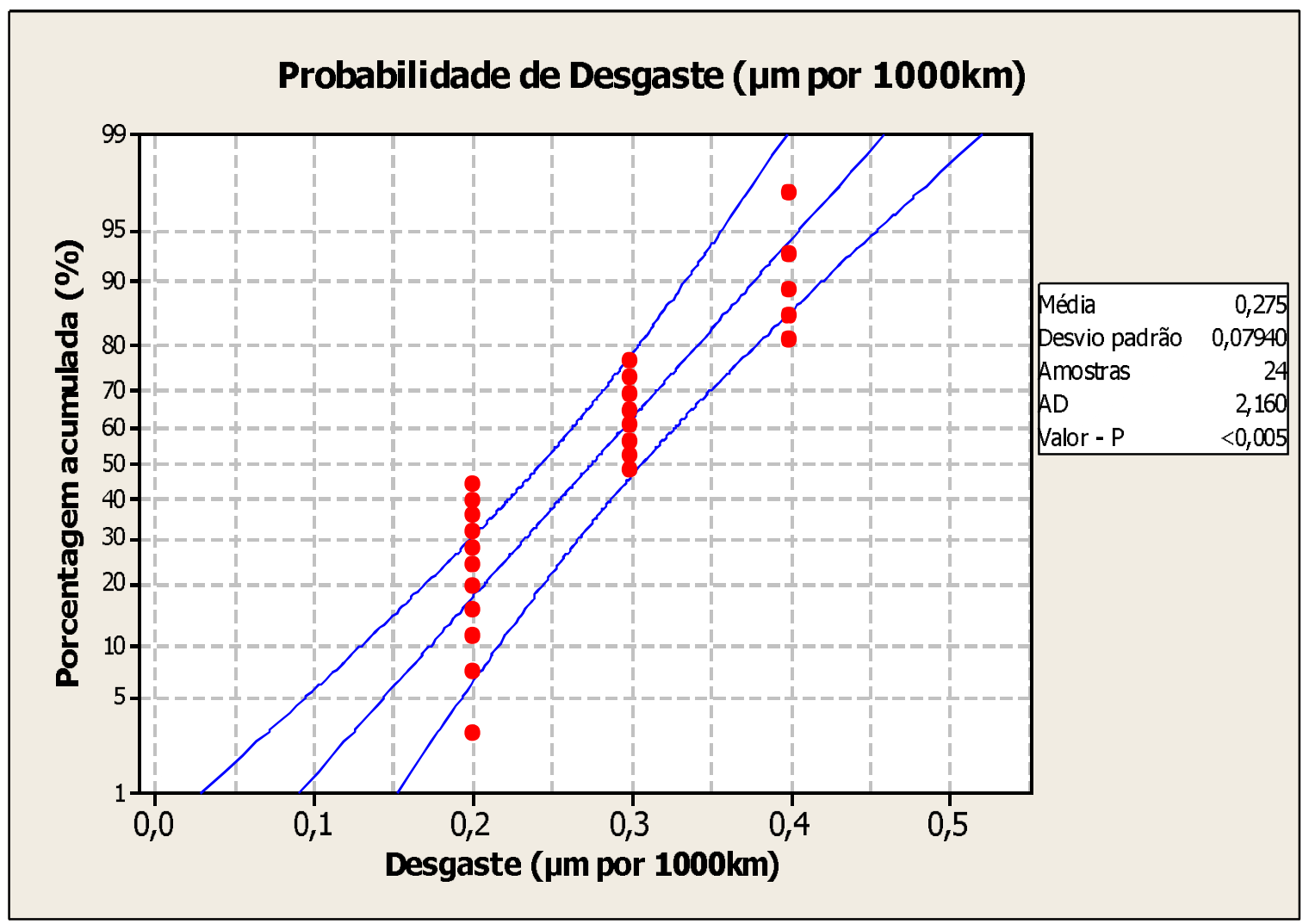

Fonte: autor da dissertação.

Como já citado anteriormente existem poucos estudos citados em literatura relacionados ao nível e tipo de desgaste que ocorre em válvula e sede de válvulas de admissão de motores diesel em condições reais de funcionamento. Um estudo encontrado denominado Wear and Wear Mechanism Simulation of HeavyDuty Engine Intake Valve and Seat Inserts, conforme WANG et al, (1998) realiza uma simulação em bancada de um tipo de válvula contra oito tipos de diferentes de sedes de válvula de admissão, sendo que cada conjunto rodou 864000 ciclos em temperatura constante de $510^{\circ} \mathrm{C}$ e com aplicação de carga de 17640 N. Após o ensaio de cada peça foi medido o desgaste do conjunto da mesma maneira que medimos durante a verificação do nível de desgaste neste trabalho e os resultados estão na Figura 49. 
Figura 49 - Ensaio de desgaste de um tipo de válvula contra vários tipos de sede de válvula de admissão (ensaio de bancada).

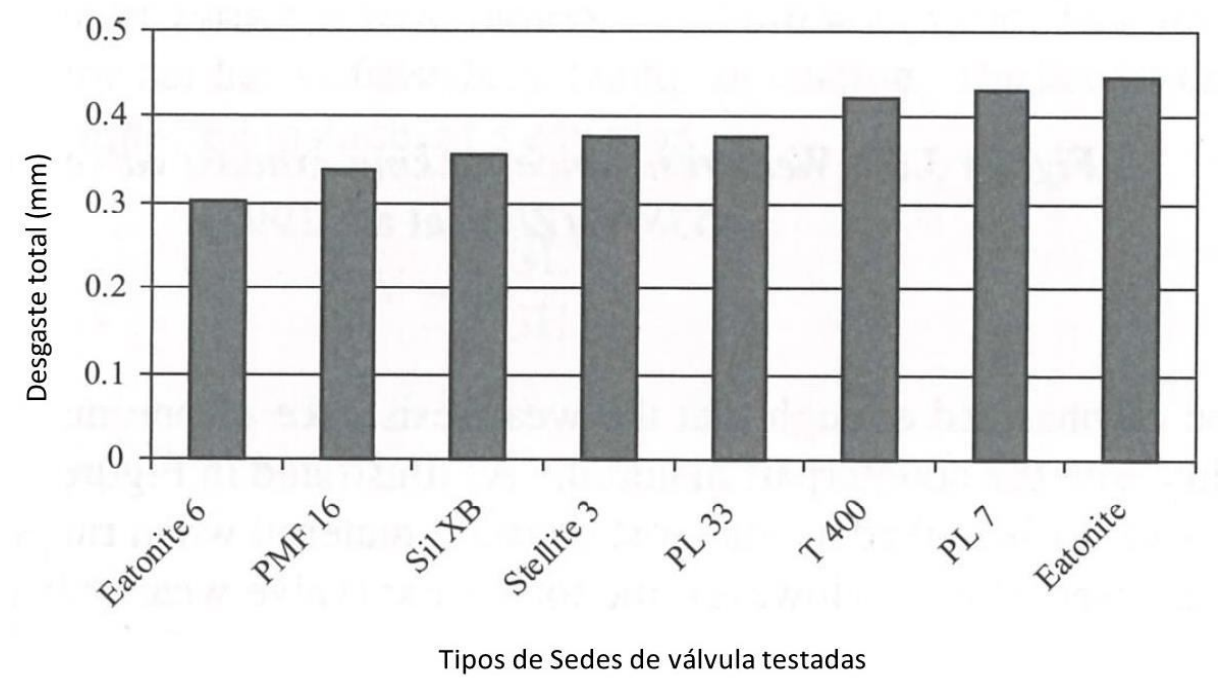

Fonte: Adaptado de Wang et al , 1998.

Quando convertemos o ensaio de durabilidade de dinamômetro de horas em número de ciclos, para conhecer a quantidade de vezes que a válvula de admissão abre e fecha durante o ensaio completo temos o valor de 120.245 .000 ciclos de abertura e fechamento das válvulas em 2000 horas de teste com carga máxima de $19204 \mathrm{~N}$ e temperatura máxima de $438^{\circ} \mathrm{C}$, conforme Figura 26. Como já foi mencionado na Tabela 18 o máximo desgaste observado no ensaio de durabilidade em dinamômetro foi de $0,074 \mathrm{~mm}$. Com isso podemos concluir que a simulação de bancada é muito mais severa que a realidade servindo somente para seleção de componentes quando por exemplo, existe mais de uma opção e se queira selecionar aquela que apresente melhor desempenho na simulação, mas que a durabilidade realmente só poderá ser conclusiva quando executada em condições reais de funcionamento.

\subsubsection{Análises Metalúrgicas (propriedades dos materiais)}

Foram analisadas a microestrutura da válvula e sede de válvula do ensaio de durabilidade veicular e comparadas com os requisitos de projeto.

$\mathrm{Na}$ Figura 50 e suas divisões, mostram-se o aspecto visual das válvulas e sede de válvulas de admissão após o ensaio de durabilidade veicular. 
Figura 50 - (a) Face do cabeçote (b) Válvula 1 e 2 do ensaio e (c) sede 1 e 2 após ensaio de durabilidade veicular. Foi escolhido um conjunto para analises metalúrgicas.

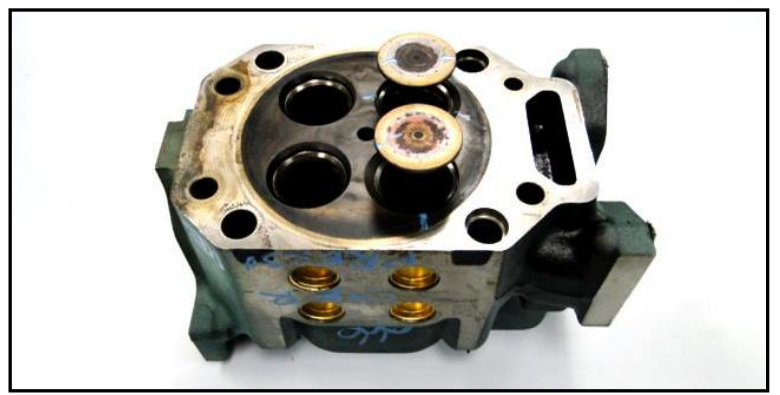

a

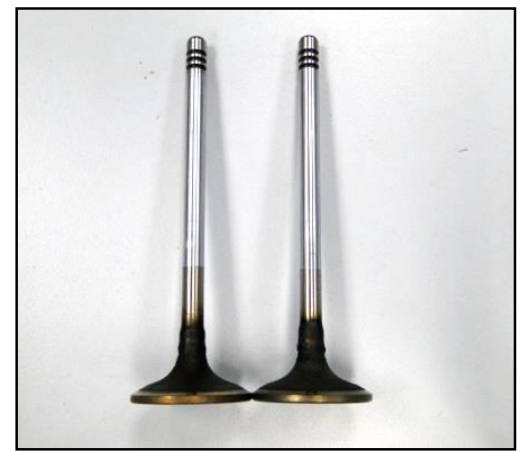

b

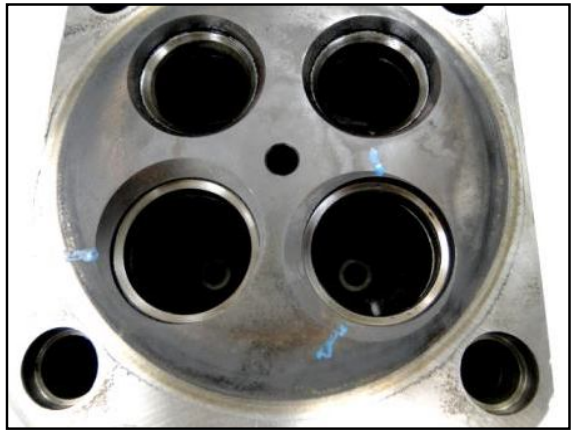

C

Fonte: autor da dissertação.

Os resultados apresentados na Tabela 26 são referentes à composição química das válvulas de admissão do ensaio de durabilidade veicular. Os ensaios físicos de dureza em três pontos na superfície de contato com a sede, sendo que os resultados mostram uma dureza de 50,6 até 53,0 HRC (faixa encontrada em ambas as válvulas de admissão), sendo o especificado o valor de 45 HRC mínimo.

Tabela 26 - Resultados da análise química da válvula, após durabilidade veicular.

\section{COMPOSIÇÃO QUÍMICA (\% EM MASSA)}

\begin{tabular}{c|c|c|c|c|c|c|c|c|c}
\hline \multicolumn{2}{c}{ Item } & $\mathbf{1}$ & $\mathbf{2}$ & $\mathbf{3}$ & $\mathbf{4}$ & $\mathbf{5}$ & $\mathbf{6}$ & $\mathbf{7}$ & $\mathbf{8}$ \\
\cline { 3 - 11 } & $\mathbf{C}$ & $\mathbf{S i}$ & $\mathbf{M n}$ & $\mathbf{P}$ & $\mathbf{S}$ & $\mathbf{C r}$ & $\mathbf{M o}$ & $\mathbf{V}$ \\
\hline \multirow{3}{*}{ Especificação } & mínimo & 0,80 & - & - & - & - & 16,50 & 2,00 & 0,30 \\
\cline { 2 - 11 } & máximo & 0,90 & 1,00 & 1,50 & 0,04 & 0,03 & 18,50 & 2,50 & 0,60 \\
\hline \multicolumn{2}{c}{ Resultado } & 0,85 & 0,32 & 0,89 & 0,01 & 0,005 & 16,23 & 2,16 & 0,41 \\
\hline
\end{tabular}

Fonte: autor da dissertação. 
Nas Figuras 51 (a) e (b), mostram-se análises da macroestrutura das válvulas na região da cabeça da válvula. Análises realizadas em Lupa Estereoscópica mostrando a faixa temperada das válvulas.

Figura 51 - Macrografias em lupa estereoscópica mostrando os perfis da têmpera da válvula na região de contato entre a válvula de admissão e sede das peças 1 (a) e 2 (b) respectivamente - perfis em ordem, após durabilidade veicular. Ataque: Marble.

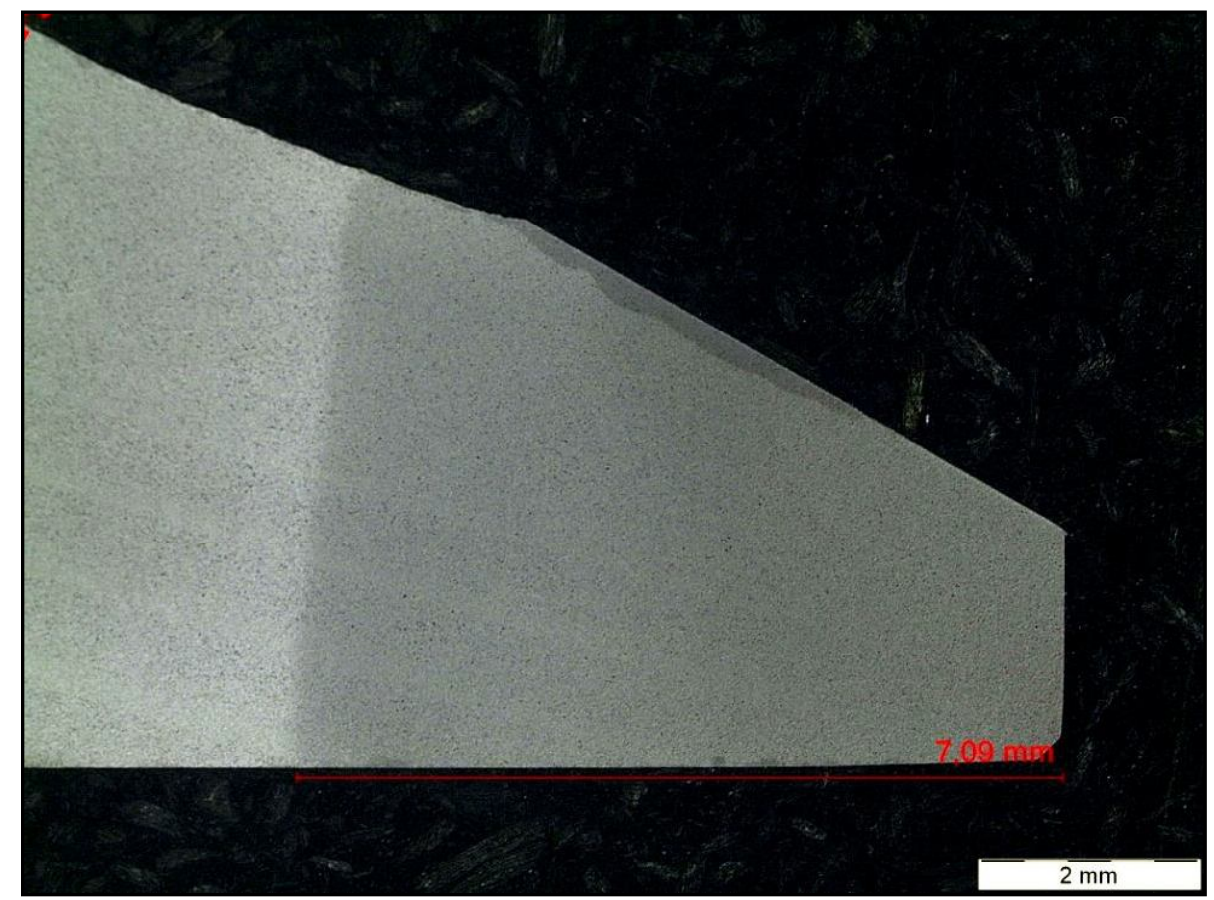

a

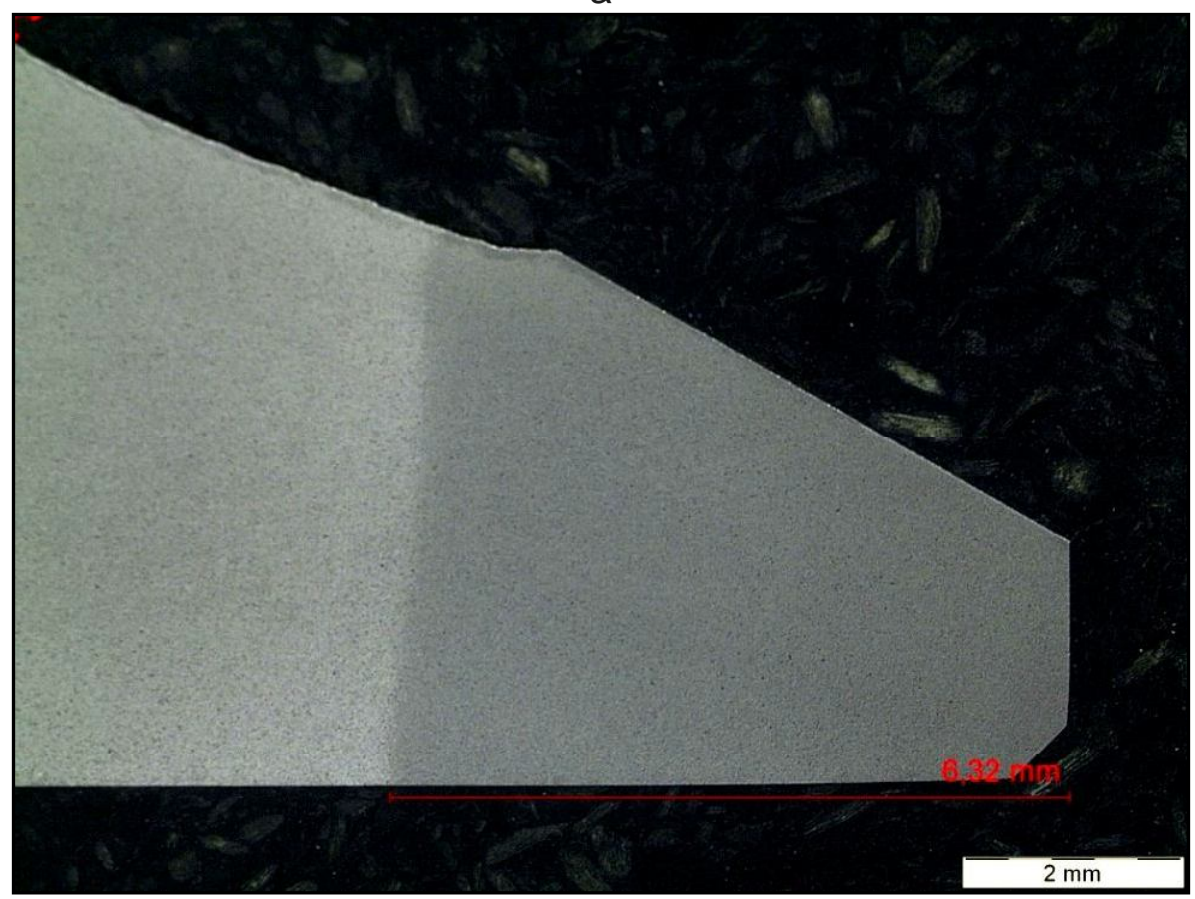

b

Fonte: autor da dissertação. 
$\mathrm{Na}$ Figura 52, mostram-se os aspectos relacionados à análise da microestrutura na cabeça da válvula realizada em microscópio óptico. Na Tabela 27, informa-se o resultado metalográfico descritivo do mesmo componente.

Figura 52 - Micrografia em microscópio óptico mostrando a estrutura da matriz na região da cabeça da válvula. Martensita revenida e carbonetos bem distribuídos, após durabilidade veicular. Ataque: Marble.

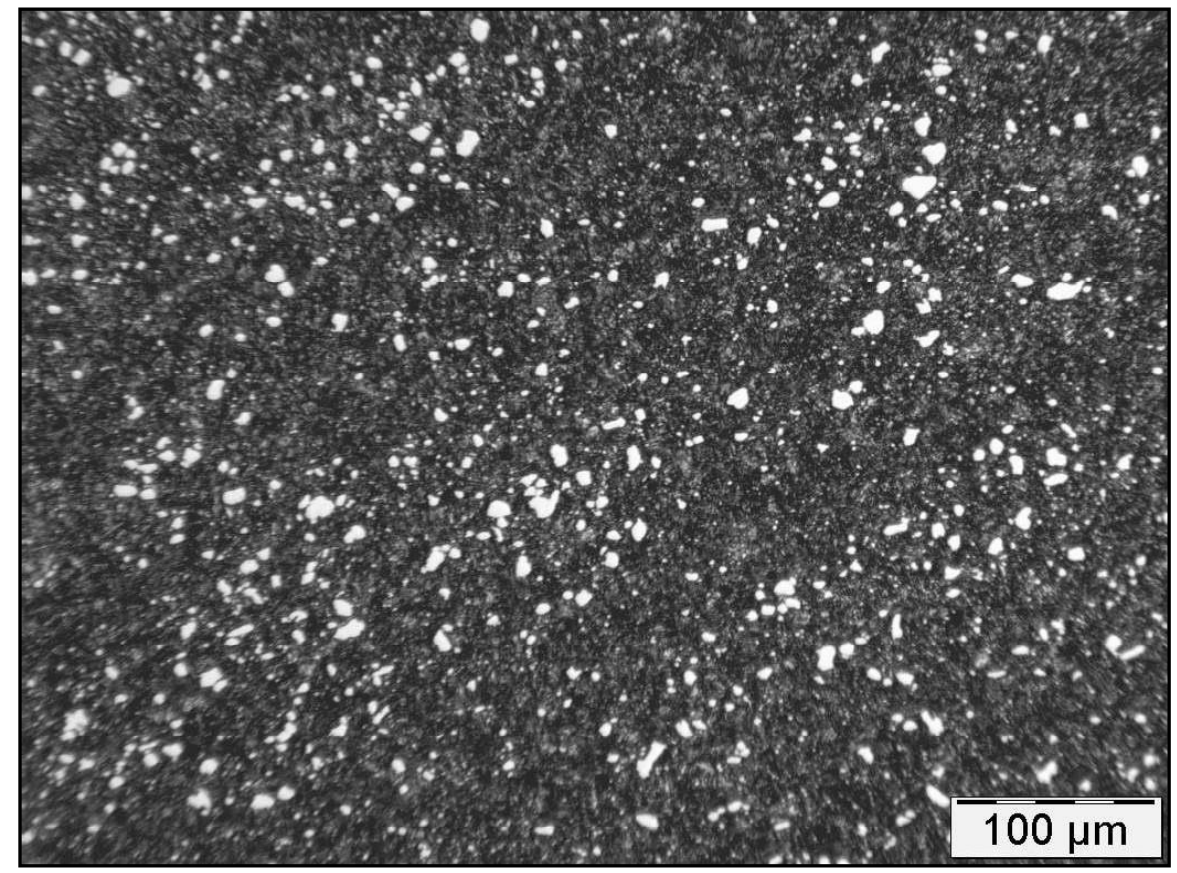

Fonte: autor da dissertação.

Tabela 27 - Resultados da análise metalográfico da válvula, após durabilidade veicular.

\begin{tabular}{c|l|l}
\hline Item & \multicolumn{1}{|c|}{ Especificado } & \multicolumn{1}{|c}{ Encontrado (*) } \\
\hline $\mathbf{1}$ & Estrutura da matriz: Beneficiada & Beneficiada \\
\hline $\mathbf{2}$ & Carbonetos: Distribuídos Uniformemente & $\begin{array}{l}\text { Distribuídos } \\
\text { uniformemente }\end{array}$ \\
\hline $\mathbf{3}$ & Descarbonetação: Ausente & Ausente \\
\hline $\mathbf{4}$ & Trincas e dobras: Ausentes & Ausentes \\
\hline $\mathbf{5}$ & $\begin{array}{l}\text { Profundidade da têmpera por indução na região } \\
\text { de assentamento da sede - (Rht 385 HV1) - } \\
\text { Detalhe Z: } 1,6 \text { mm mínimo }\end{array}$ & Têmpera total \\
\hline
\end{tabular}

$(*)$ Considerar para ambas peças.

Fonte: autor da dissertação. 
Assim como conduzido para a válvula de admissão a caracterização metalúrgica da sede de válvulas de admissão foi conduzida no mesmo cabeçote anteriormente identificado na Figura 50 (c). Os resultados apresentados nas Tabelas 28 e 29 e nas Figuras 49 (a) e (b) são pertinentes à sede de válvula de admissão do ensaio de durabilidade veicular.

Os resultados apresentados na Tabela 28 são referentes à composição química das válvulas de admissão do ensaio de durabilidade veicular. Os ensaios físicos de dureza em três pontos na superfície de contato com a sede, sendo que os resultados mostram uma dureza de 51,1 até 54,1 HRC (faixa encontrada em ambas as sedes de válvulas) e o especificado é de 45 a 55 HRC. Na Tabela 29, informa-se o resultado metalográfico descritivo das sedes de válvulas.

Tabela 28 - Resultados da análise química da sede de válvula, após durabilidade veicular.

\begin{tabular}{c|c|c|c|c|c|c|c|c|c|c|c}
\hline \multicolumn{7}{c}{ COMPOSIÇÃO QUíMICA (\% EM MASSA) - Amostra } \\
\hline Item & $\mathbf{1}$ & $\mathbf{2}$ & $\mathbf{3}$ & $\mathbf{4}$ & $\mathbf{5}$ & $\mathbf{6}$ & $\mathbf{7}$ & $\mathbf{8}$ & $\mathbf{9}$ & $\mathbf{1 0}$ & $\mathbf{1 1}$ \\
\hline & $\mathrm{C}$ & $\mathrm{Co}$ & $\mathrm{Mo}$ & $\mathrm{W}$ & $\mathrm{V}$ & $\mathrm{Cr}$ & $\mathrm{Si}$ & $\mathrm{Mn}$ & $\mathrm{S}$ & $\mathrm{Cu}$ & $\mathrm{Fe}$ \\
\hline Especificação & 0,80 & 15,0 & 9,0 & 2,5 & 1,3 & 3,5 & 0,5 & 0,3 & 0,15 & 10,0 & Restante \\
& & & & & & & & & & & \\
\hline & 1,30 & 22,0 & 14,0 & 4,5 & 2,3 & 5,5 & 2,0 & 1,5 & 0,75 & 20,0 & \\
\hline Resultados & 1,01 & 17,01 & 12,62 & 3,45 & 1,51 & 4,38 & 0,83 & 0,62 & 0,39 & 16,66 & Restante \\
\hline
\end{tabular}

Fonte: autor da dissertação.

Tabela 29 - Resultados da análise metalográfica da sede de válvula, após durabilidade veicular.

\begin{tabular}{|c|c|c|}
\hline Item & Especificado & Encontrado (*) \\
\hline 1 & Estrutura da matriz: Martensita revenida & Martensita revenida \\
\hline 2 & Carbonetos: Finos e distribuídos uniforme em uma fase intermediária & $\begin{array}{l}\text { Finos e distribuídos uniforme em uma fase } \\
\text { intermediária }\end{array}$ \\
\hline 3 & $\begin{array}{l}\text { Lubrificantes sólidos: Distribuídos uniformemente e os poros } \\
\text { preenchidos com Cobre }\end{array}$ & $\begin{array}{l}\text { Distribuídos uniformemente e os poros } \\
\text { preenchidos com Cobre }\end{array}$ \\
\hline 4 & $\begin{array}{l}\text { Descontinuidades superficiais não são admissíveis se interferirem na } \\
\text { rugosidade especificada em desenho }\end{array}$ & Em ordem \\
\hline 5 & Não é admissível qualquer indicio de trinca nas sedes de válvulas & Em ordem \\
\hline $\mathbf{6}$ & $\begin{array}{l}\text { Não são admitidas irregularidades superficiais região compreendida } \\
\text { entre os pontos } \mathrm{p} 1 \text { e } \mathrm{p} 4 \text { (1) }\end{array}$ & Em ordem \\
\hline 7 & $\begin{array}{l}\text { Demais regiões: São aceitos no máximo (5) cinco irregularidades } \\
\text { superficiais por peça, desde que não tenham diâmetro e/ou } \\
\text { profundidade superiores a } 0,8 \mathrm{~mm} \text {, e tenham distância entre si } \\
\text { superior a } 3,2 \mathrm{~mm}(1)\end{array}$ & Em ordem \\
\hline
\end{tabular}


Fonte: autor da dissertação.

Nas Figuras 53 (a) e (b), mostram-se a microestrutura da sede de válvula realizada em microscópio óptico. As análises foram realizadas em ambiente de ensaio com temperatura $21^{\circ} \mathrm{C}$ e umidade $57 \%$.

Figura 53 - Micrografias (a) e (b) em microscópio óptico mostrando a estrutura da matriz da sede de válvula- Martensita revenida com carbonetos finos distribuídos uniformemente e poros preenchidos com Cobre, após durabilidade veicular.. Ataque: Nital 3\%.

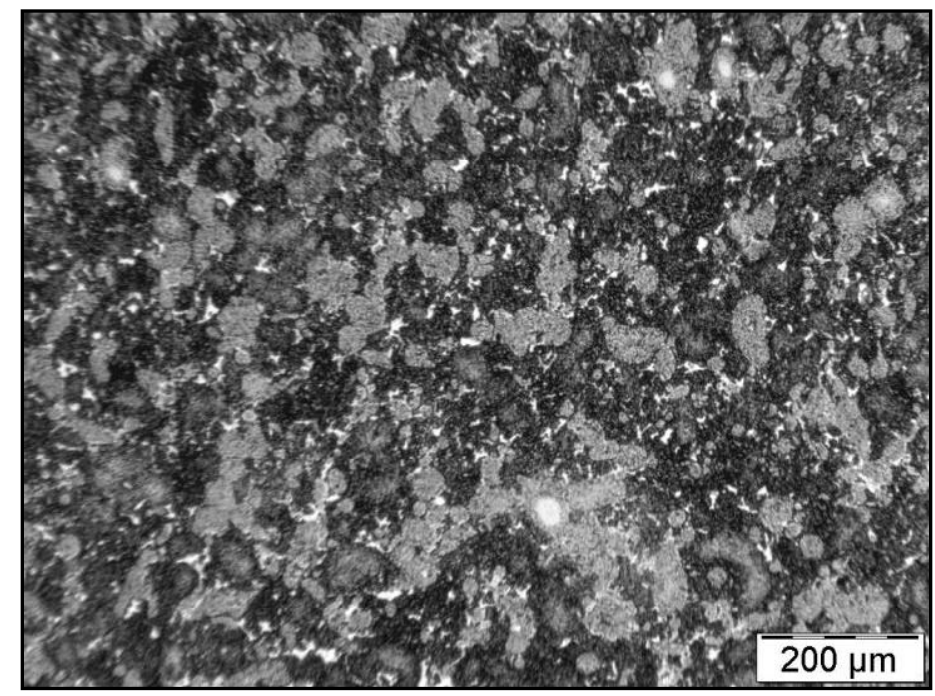

a

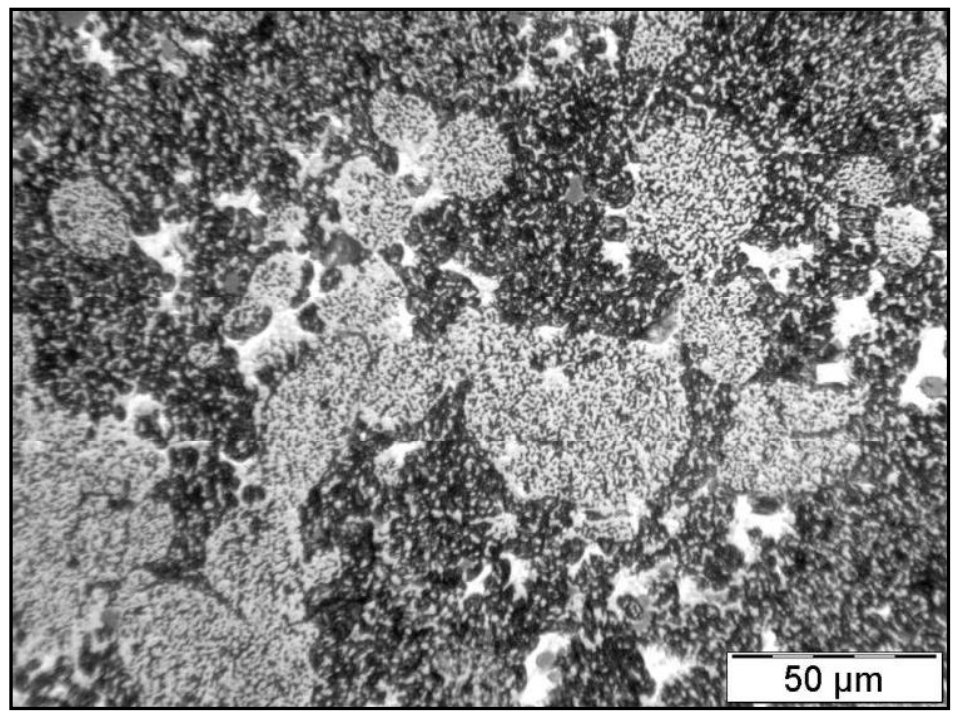

b

Fonte: autor da dissertação.

Todas as propriedades metalúrgicas analisadas, sejam elas químicas ou físicas, estavam de acordo com o especificado, ou seja, as peças testadas estavam 
conforme projeto original. Quanto às análises microestruturais, a comparação entre a válvula de referência analisada antes dos testes (Figura 28), a válvula analisada após o teste de durabilidade em dinamômetro (Figura 37) e a válvula analisada após o teste de durabilidade veicular (Figura 50), mostram características praticamente iguais, ou seja, a estrutura da matriz na região da cabeça - martensítica se apresentou com carbonetos bem distribuídos.

As sedes de válvula mostram microestrutura similar entre as peças analisadas, conforme Figuras 31 e 32 (referência analisada antes dos testes), 40 e 41, que foram analisadas após o teste de durabilidade em dinamômetro e 53 (a) e (b), que foram analisadas após o teste de durabilidade veicular.

Os valores de composição química são comparados para as válvulas nas Tabelas 10 (referência analisada antes do teste), 20 (analisada após o ensaio de durabilidade em dinamômetro) e 26 (analisada após o ensaio de durabilidade veicular) e mostram resultados correspondentes ao campo aceitável para cada elemento da composição. As sedes de válvulas apresentam resultados de composição química dentro da referência especificada para o material, conforme Tabelas 14 (referência analisada antes do teste), 23 (analisada após o ensaio de durabilidade em dinamômetro) e 28 (analisada após o ensaio de durabilidade em veículo).

Os resultados físicos de medição de dureza (que são evidenciados nos descritivos e nas Tabelas para as válvulas e sedes de válvulas) indicam uma grande compatibilidade de dureza, uma vez que as válvulas analisadas mostram valores que variam de 50,8 - 53HRC e as sedes de válvulas analisadas valores que estão entre $49,0-54,1 \mathrm{HRC}$.

\subsubsection{Análise do tipo de desgaste (contato válvula e sede de válvula)}

Através do microscópio eletrônico de varredura foi analisado o desgaste na superfície de contato da válvula e da sede de válvula utilizando imagens a partir de elétrons retro espalhados (BSE) e elétrons secundários (SEI) e espectroscopia por energia dispersiva (EDS). Nas Figuras 54, 55, 56 e 57, mostram-se detalhes do tipo de desgaste. 
Figura 54 - Análise através de espectroscopia por energia dispersiva (EDS) comparativa entre superfície de assento de válvula (a) e superfície da sede de válvula (b). Análise EDS realizada em corte transversal. Nota-se em (b) alta concentração de cobre originário da sede de válvula, após durabilidade veicular.

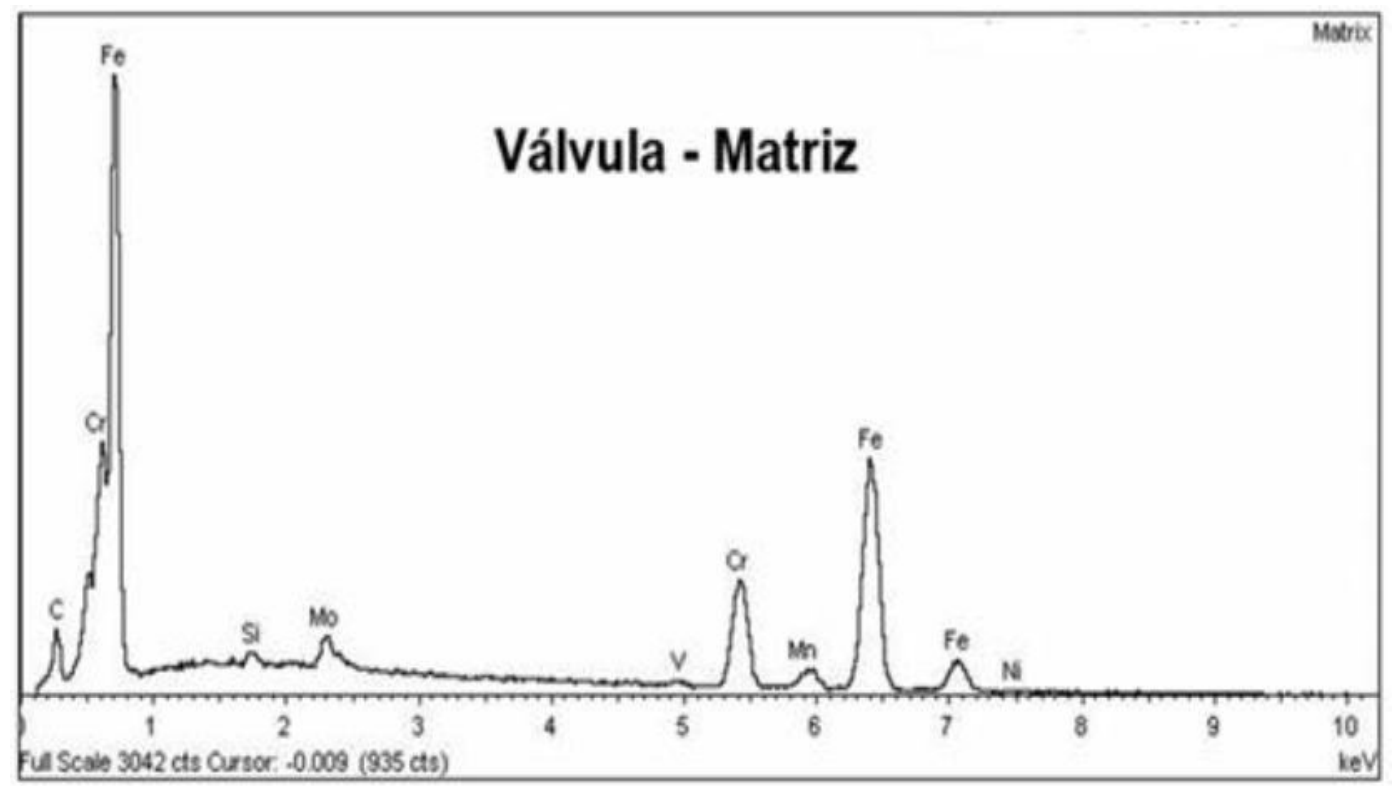

a

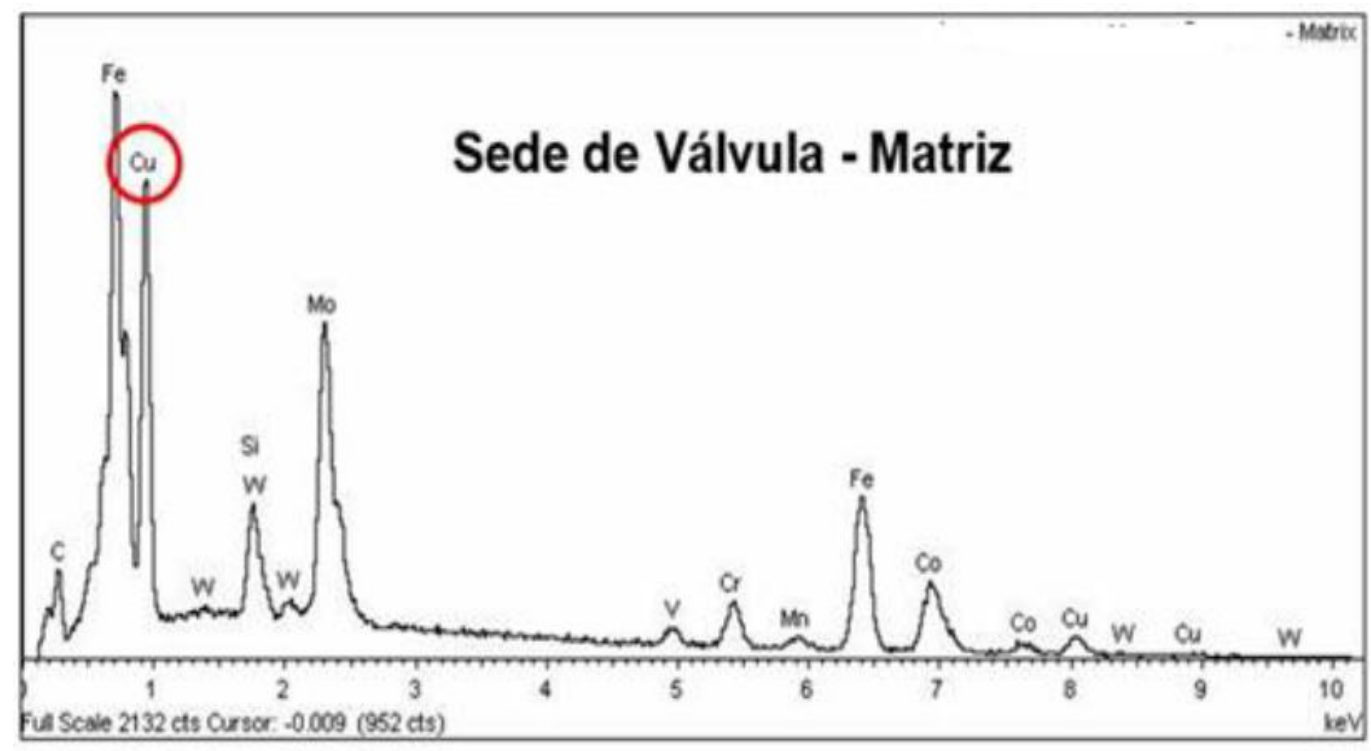

b

Fonte: autor da dissertação. 
Figura 55 - A análise de superfície por MEV realizada no contato da válvula com a sede de válvula, que apontou características de desgaste Adesivo. O desgaste do adesivo está relacionado com tensões de cisalhamento elevadas causadas pela fricção. Observou-se regiões cinzentas (c), com presença significativa do elemento cobre $(\mathrm{Cu})$, vide Figura 56, material transferido da sede de válvula, após durabilidade veicular.

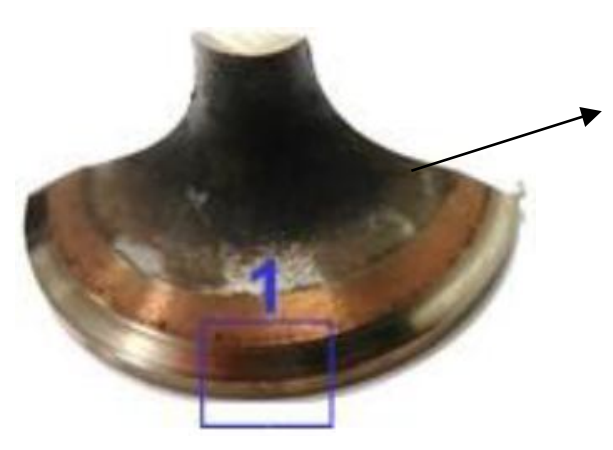

a

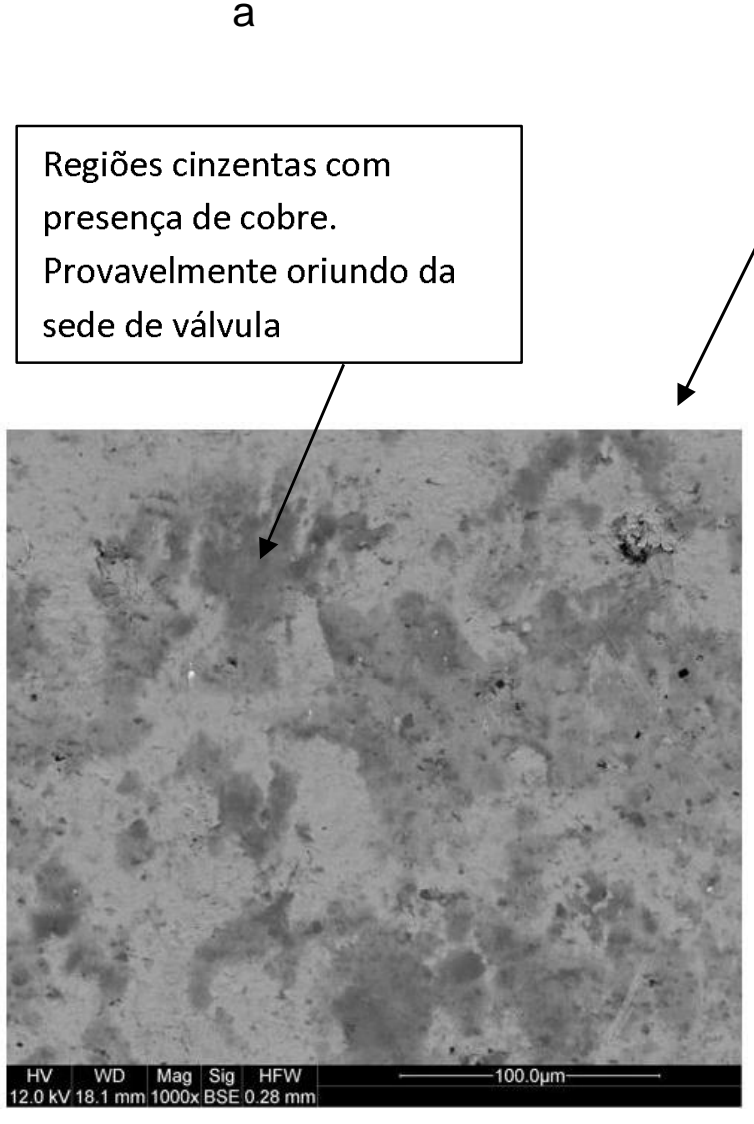

C

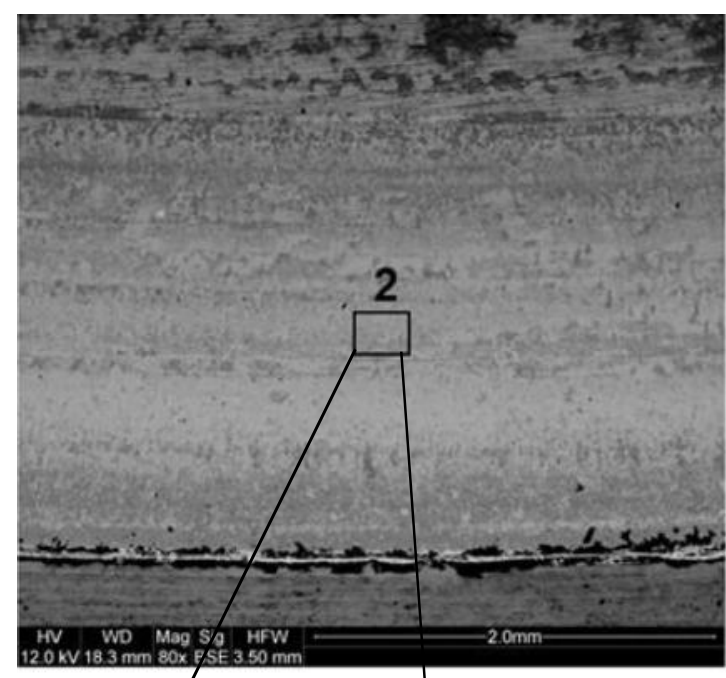

b
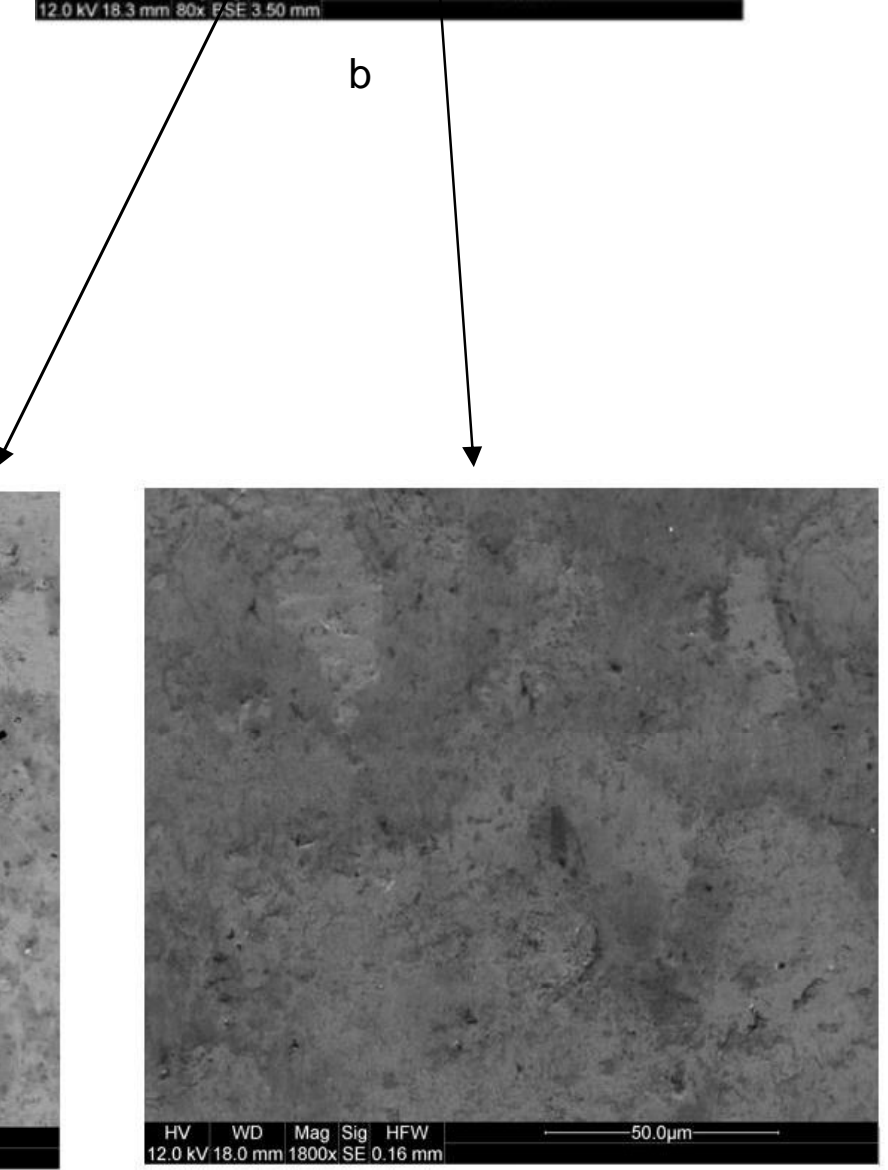

d

Fonte: autor da dissertação. 
Figura 56 - Análise em MEV / EDS mostrando a presença do elemento cobre (Cu) - material transferido da sede de válvula para a válvula, após durabilidade veicular.
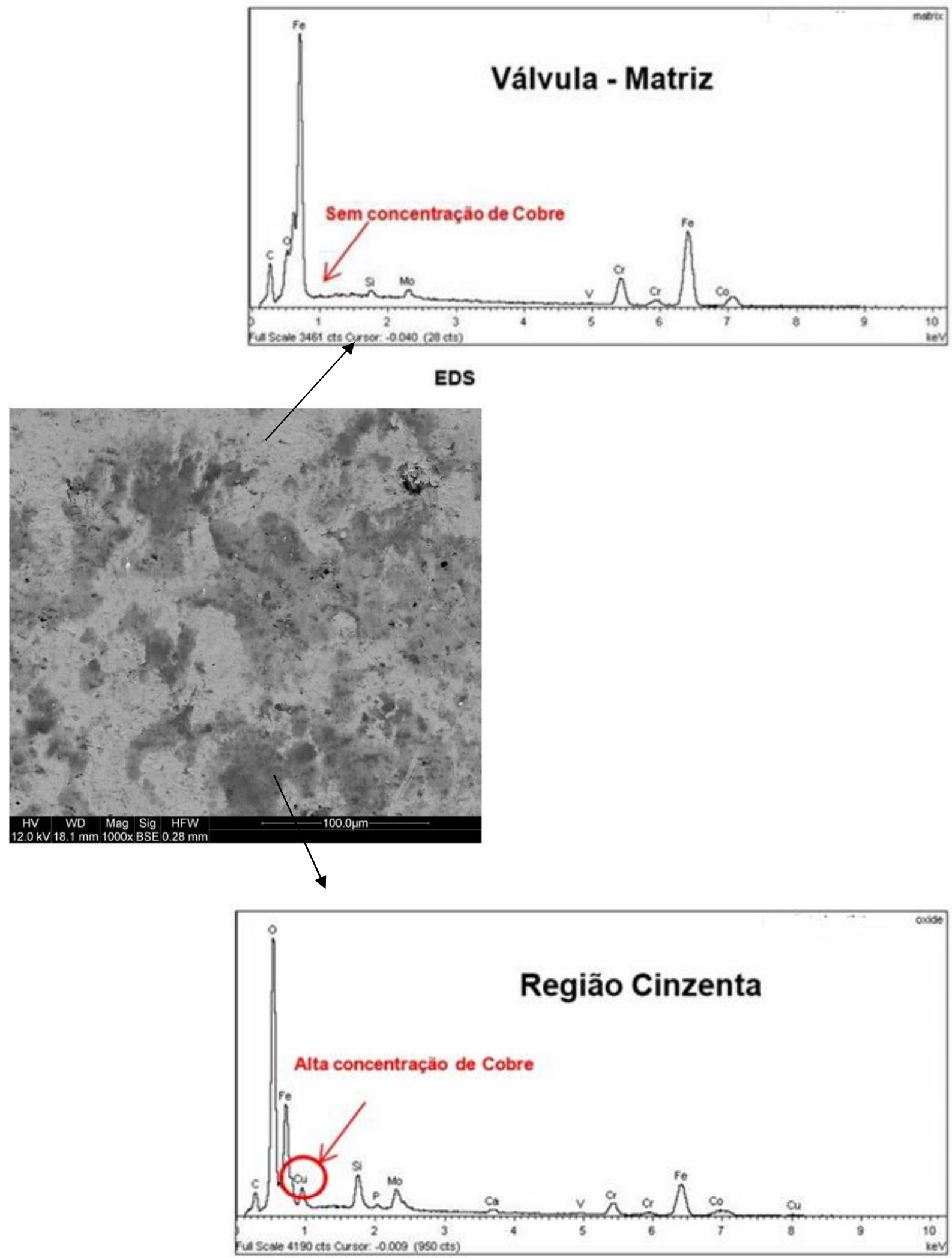

EDS

Fonte: autor da dissertação. 
Figura 57 - A análise de superfície por MEV realizada sobre a superfície de contato da sede de válvula mostrou deformação plástica e pequenos destacamentos de material na superfície - características de desgaste adesivo, após durabilidade veicular.

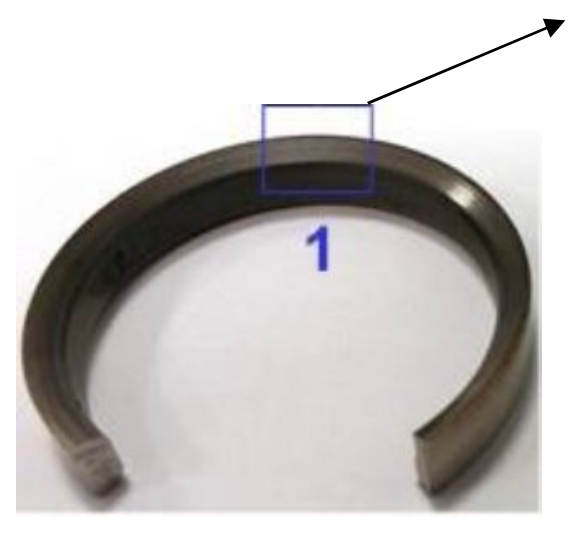

a

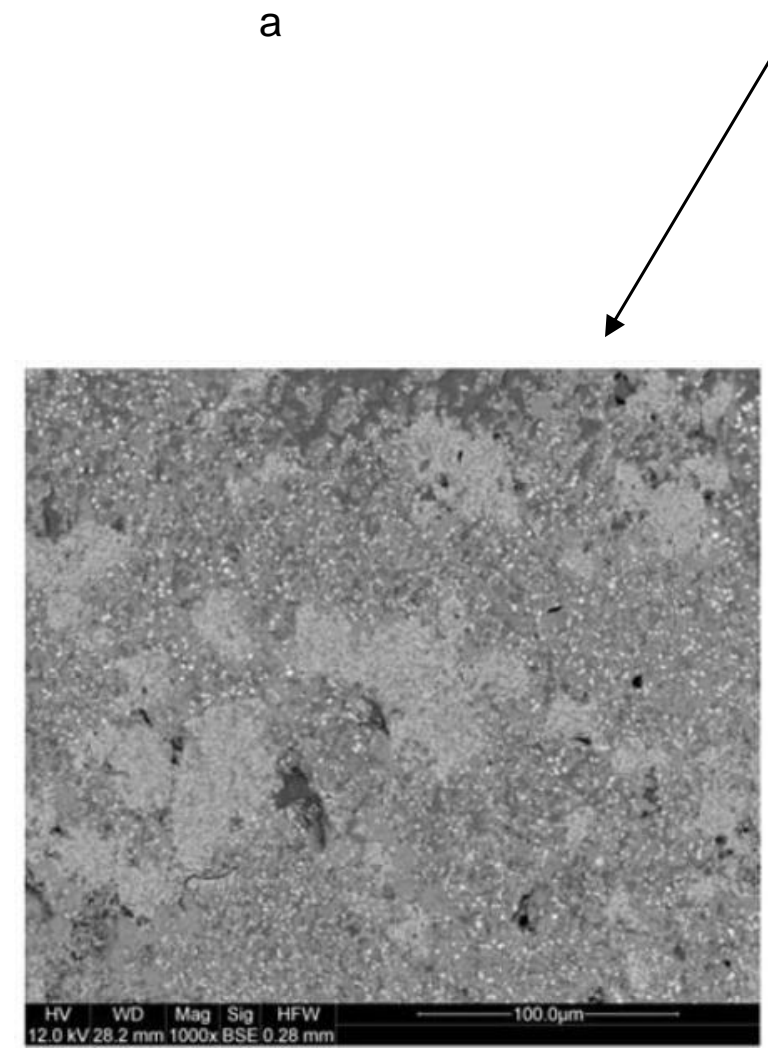

C

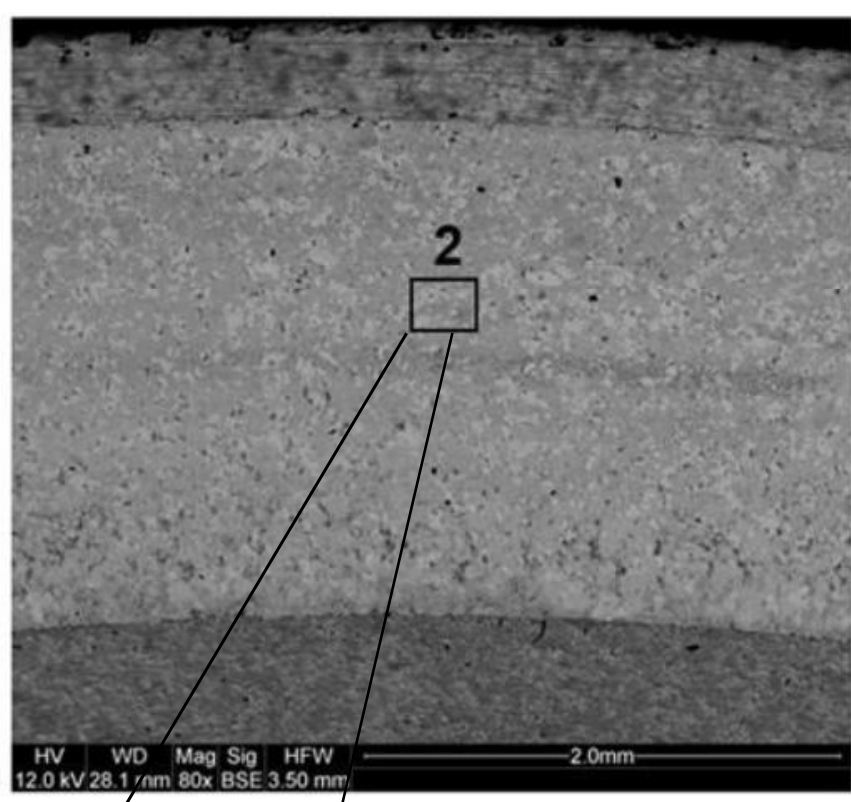

b

Destacamento de material da superfície e deformação plástica

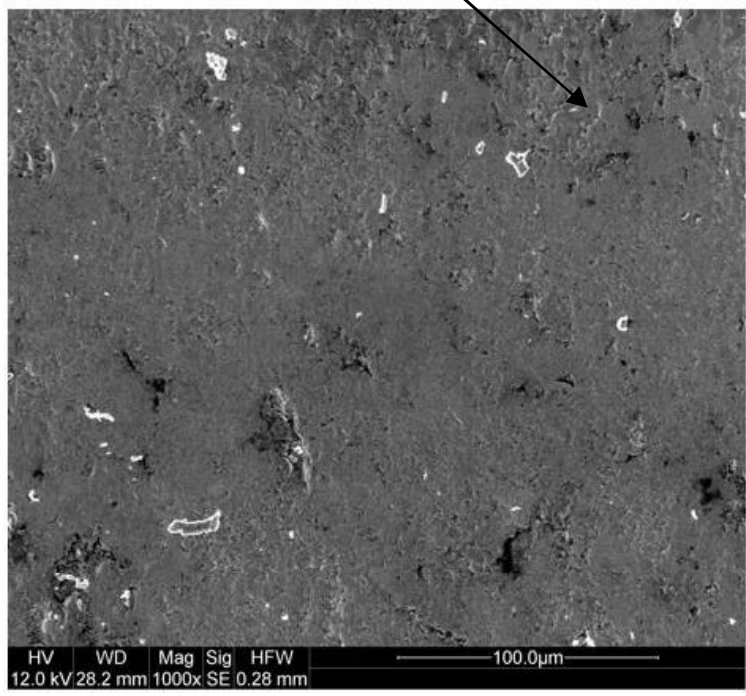

d

Fonte: autor da dissertação. 
A literatura conforme BASSHUYSEN e SCHAFER (2004) traz alguns mecanismos de desgastes observados para o par tribológico válvula e sede de válvula. Os principais fatores de desgaste são:

- Carga mecânica na área do assento da válvula (força da mola, força de fechamento e pressão de combustão);

- Cargas dinâmicas exercidas sobre a sede da válvula devido ao movimento relativo da válvula com a sede de válvula (rotação);

- Lubrificação;

- Par tribológico em desgaste, a válvula (compatibilidade entre materiais).

Segundo WANG (2007) os tipos de desgaste para o par tribológico válvula e a sede de válvula são classificados de três maneiras:

- Remoção de metal;

- Adesão;

- Deslocamento de material por fluxo plástico.

O desgaste observado através das análises de microscopia eletrônica de varredura mostra que o mesmo ocorreu de duas maneiras: a primeira de característica adesiva, pois foi verificada a transferência de material da sede para a válvula, conforme observado nas Figuras 43, 44 e 45, uma vez que a definição de desgaste adesivo é uma aderência localizada entre o contato sólido das duas superfícies (válvula e sede de válvula), levando à transferência de material entre as superfícies ou perda de material de qualquer uma das superfícies (WANG, 2007); a segunda, conforme observado nas Figuras 55, 56 e 57 foi a deformação plástica em um nível leve (também conhecido como desgaste sob tensão de cisalhamento ou fluxo radial) ao logo da direção de deslizamento devido à alta tensão de contato, a temperatura elevada na superfície, alto atrito na interface e dureza a quente inadequada (WANG, 2007).

Conforme já discutidos os níveis de degaste apresentados pelo conjunto apresentaram resultados que superaram as expectativas e até mesmo valores menores que os citados em literatura. Aspectos relacionados ao material da sede de válvula, em especial, confere características importantes ao componente, que evitam o desgaste excessivo, sendo que dentre as quais podemos citar:

- Preenchimento dos poros com cobre, conforme Figura 58; 
- Lubrificante sólido, conforme Figura 58;

- Fases intermetálicas, conforme Figura 59.

A Figura 60 mostra a micrografia da sede de válvula com detalhes da região com cobre (regiões alaranjadas), que recobre os poros do componente. $\mathrm{O}$ preenchimento dos poros com cobre diminui o coeficiente de atrito e melhora a condutividade térmica, conforme $\mathrm{OH}$ et al (1991). Na mesma Figura, mostram pontos quase esféricos de coloração acinzentadas, que são os lubrificantes sólidos (sulfato de manganês), que conferem ao componente uma melhor usinabilidade e diminui o atrito entre superfícies.

Figura 58 - Micrografia da sede de válvula em microscópio óptico mostrando a estrutura da matriz da sede de válvula. Ataque: Nital $3 \%$.

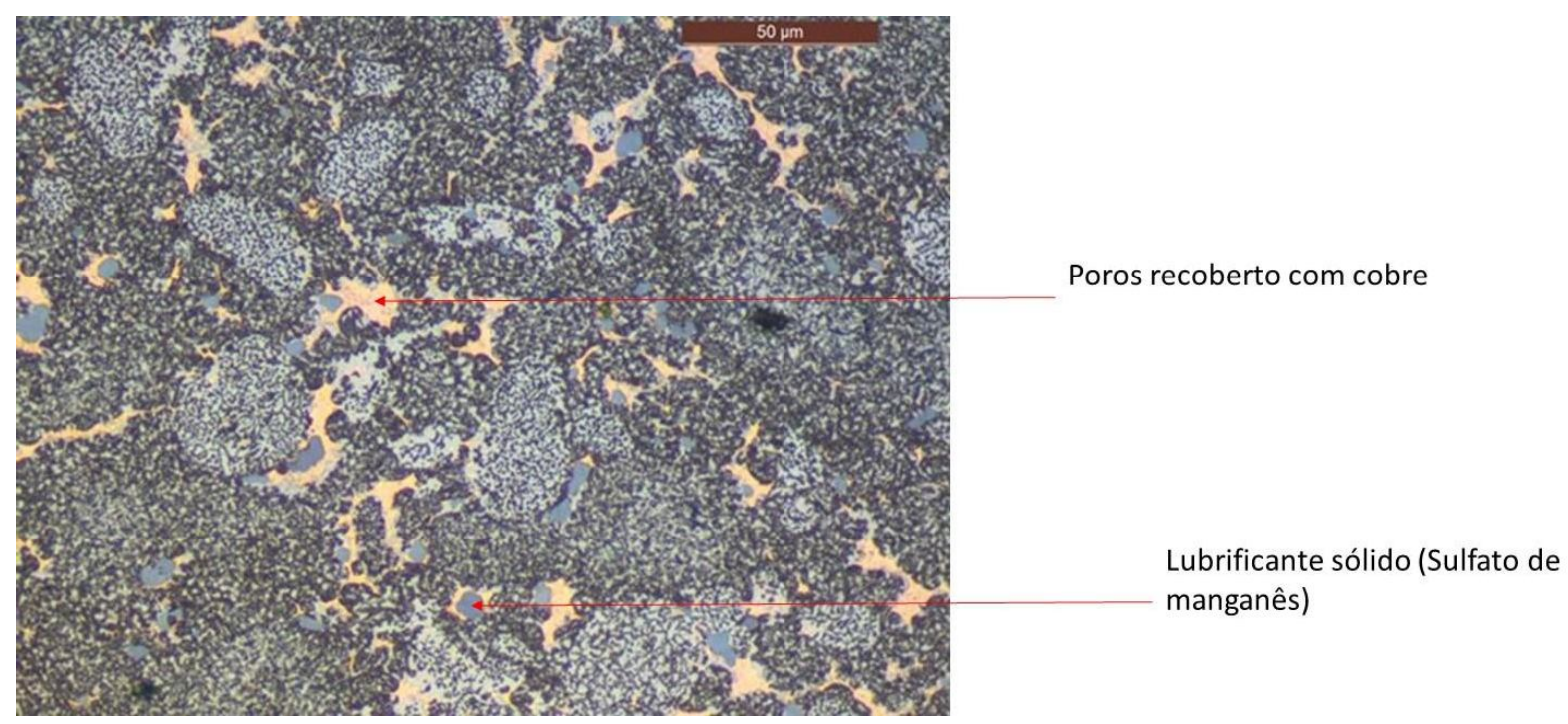

Fonte: autor da dissertação.

Para identificar a fase intermetálica que se forma na sede de válvula foi utilizada a técnica de difração de raio-x. O fenômeno da difração é definido como um fenômeno de espalhamento de radiação eletromagnética por um arranjo periódico de centros de espalhamento, com espaçamento da mesma ordem de magnitude do comprimento de onda da radiação incidente LIMA (2007). Na Figura 59, mostra-se um difratograma completo da sede de válvula que identifica fase intermetálica (carboneto de cobalto molibdênio - $\mathrm{Co}_{6} \mathrm{Mo}_{6} \mathrm{C}_{2}$ ) contida no material. Conforme verificado em CIMM (2017) a formação de carbonetos de cobalto molibdênio confere ao material uma excelente resistência ao desgaste. 
Figura 59 - Difratograma identificando elementos da sede de válvula, com destaque para a fase intermetálica contida no material da sede de válvula (carboneto de cobalto molibdênio $\mathrm{Co}_{6} \mathrm{Mo}_{6} \mathrm{C}_{2}$ ), conforme identificado e comparado na literatura, (NEWSAM et al ,1988).

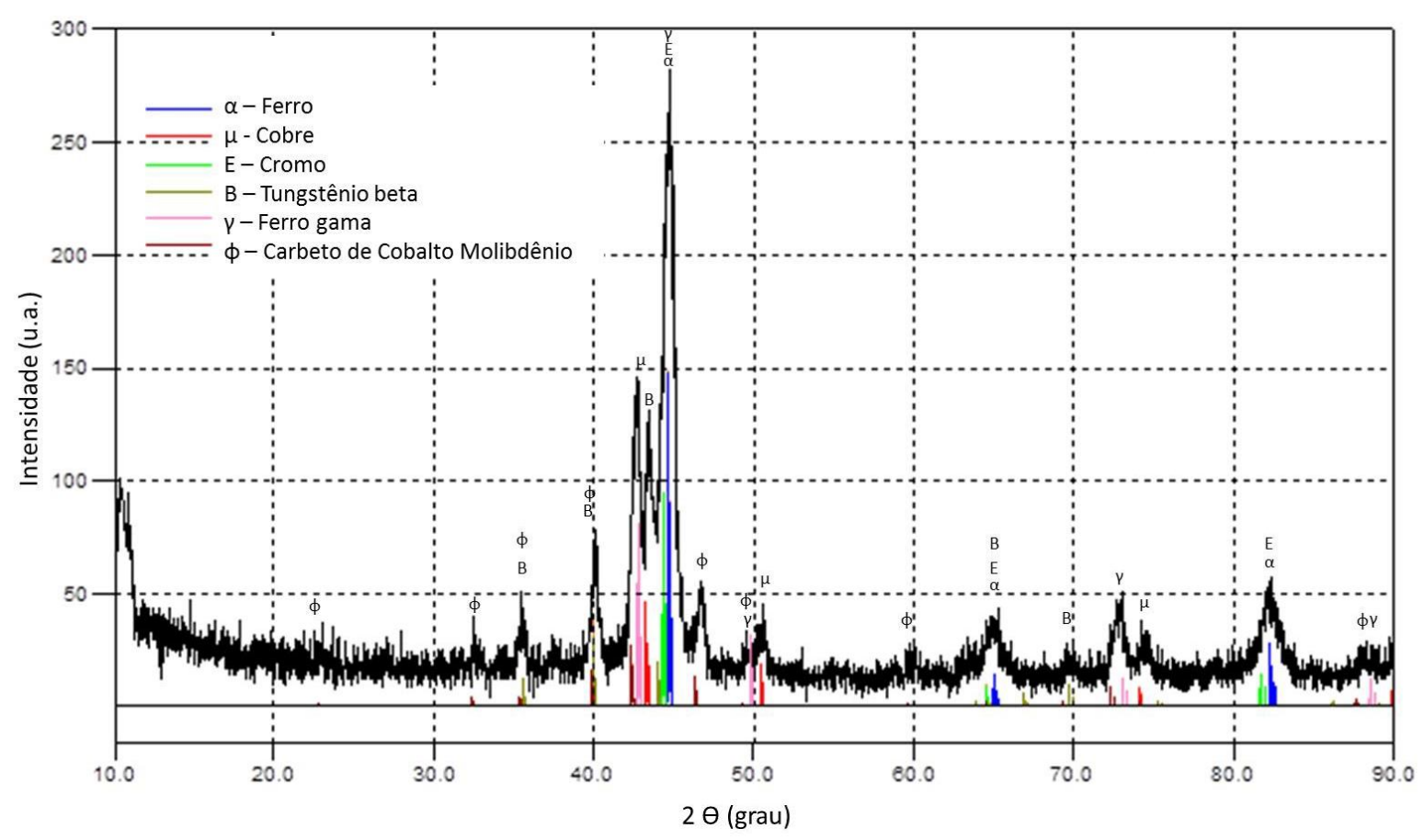

Fonte: autor da dissertação.

O gráfico apresentado na Figura 59 é um difratograma, que mostra os elementos contidos na sede de válvula. Através de um difratômetro gerou-se o gráfico apresentado na linha em preto, que conforme as intensidades das linhas de difração (eixo das ordenadas), apresenta um padrão para cada tipo de material. 0 padrão depende dos tipos de átomos, arranjo destes na rede cristalina e orientação cristalográfica. O eixo das abscissas corresponde ao ângulo $\Theta$ (lei de Bragg), contudo o detector do difratômetro varre a amostra num ângulo de $2 \theta$, sendo que a posição angular das linhas de difração depende da geometria da rede cristalina, indicando o tamanho e a forma da célula unitária, conforme (LIMA, 2007). Todos os dados obtidos no difratômetros são comparados e identificados através de cartas contidas na literatura para cada tipo de material, conforme as linhas coloridas da Figura 59. 


\section{CONCLUSÕES}

O par tribológico válvula e sede de válvula foi submetido a avaliações em condições reais de funcionamento tanto em dinamômetro (ambiente de laboratório controlado), como também em ensaios de durabilidade veicular e, em ambas as situações, o conjunto mostrou excelente desempenho. Este fato é comprovado pelos resultados obtidos tanto para os requisitos legais de desempenho e emissões de poluentes, quanto para os requisitos de operação relacionados à vida e manutenção do produto.

Quanto ao desempenho, os resultados obtidos com as válvulas e sedes de válvulas, com base nos motores testados, apresentam condições operacionais adequadas às temperaturas e pressões de combustão submetidas. Quanto à temperatura de operação, os valores obtidos nos ensaios mostraram-se abaixo do limite especificado para o material da válvula e da sede de válvula. Quanto às grandezas de temperatura e pressão de combustão em conjunto, o par tribológico não apresentou desgaste excessivo que levasse à deterioração do desempenho ao longo do ensaio de durabilidade de dinamômetro, como também os valores de emissões de poluentes se mostraram estáveis. Os ensaios conduzidos em veículo mostraram que os níveis de desgaste não degradaram a vida do motor, visto que foram similares aos encontrados em dinamômetro. O mesmo ocorreu quanto aos requisitos de manutenção, pois no intervalo de 100.000 km não foi necessário ajustar as folgas de válvulas.

A compatibilidade entre o material da válvula e da sede de válvulas se mostrou bastante adequada. Os resultados do nível de desgaste obtidos nos ensaios de durabilidade, tanto em veículo quanto em dinamômetro, apresentaram valores abaixo dos mencionados em literatura e não deterioraram o desempenho do motor, principalmente nos valores de emissões de poluentes. A literatura cita valores de desgaste que vão $1 \mu \mathrm{m}$ a $5 \mu \mathrm{m}$ por $1000 \mathrm{~km}$ rodados, e o máximo valor encontrado nos ensaios foi de $0,4 \mu \mathrm{m}$ por $1000 \mathrm{~km}$. Pode-se concluir que a literatura determinou um intervalo de valores de desgaste, porém em função de diversos parâmetros tribológicos que podem influenciar o desgaste, o presente trabalho sugere que seja determinado apenas um valor máximo.

Existiu uma forte convergência da simulação computacional com os resultados dos ensaios em dinamômetro e veicular. A simulação mostra 
movimentação da válvula em relação à sede de válvula durante a operação do motor e basicamente esta movimentação faz com que ocorram os mecanismos de desgaste evidenciados nos ensaios práticos. Os desgastes observados por MEV são classificados como desgaste adesivo e leves sinais de desgaste plástico. Ambos os desgastes são citados na literatura como os mais preponderantes.

Comparando-se os ensaios em dinamômetros e veiculares foi verificada uma ótima convergência quando analisados os resultados de desgaste em taxa, pois apresentam o mesmo campo de valores. Estatisticamente não é possível comparar desgastes entre válvulas de um mesmo motor, pois os carregamentos são diferentes entre si (principalmente carregamentos térmicos), contudo é possível comparar válvulas correspondentes a um mesmo cilindro de motores diferentes, levando em consideração fatores dimensionais para esta situação.

Através de análises comparativas de desgaste do par tribológico entre simulações de bancada e de condições reais de funcionamento, podemos concluir que a simulação de bancada é muito mais severa que a realidade, servindo somente para seleção de componentes, quando por exemplo, existe mais de uma opção e se queira selecionar aquela que tem melhor desempenho. A durabilidade, porém, só poderá ser conclusiva quando executada em condições reais de funcionamento.

Diante das constatações práticas, o par tribológico, válvula e sede de válvula de admissão, cumpriram sua função básica, que é a vedação da câmara de combustão a fim de alcançar a pressão necessária para a combustão. Este fato foi confirmado em função da não deterioração de desempenho e das emissões de poluentes, além de satisfazer a requisitos extremos de trabalho, como elevadas temperaturas de operação e pressão de combustão, mantendo baixas as taxas de desgaste. 


\section{SUGESTÔES PARA TRABALHOS FUTUROS}

Para futuros trabalhos sugere-se avaliar em condições reais de funcionamento o material da sede de válvula testada neste trabalho com o material de válvula X50CrMnNiNbN 219, para o par tribológico de escape.

Sugere-se também avaliar a influência no desgaste utilizando diferentes pressões de combustão para um mesmo modelo de par tribológico de válvula e sede de válvula, com o objetivo de analisar a proporcionalidade do desgaste em função da pressão de combustão. 


\section{REFERÊNCIAS BIBLIOGRÁFICAS}

Apresentação técnica Bleistahl, Tecnologia de Sedes de Válvulas, 2012.

ASSIS, J. T; MONIN, V. I.; SOUZA, P. S.; WEIDLICH, M. C.; GUROVA, T.; TEODOSIO, J.R. Processamento dos dados de difração de raios x para medição de tensões. Disponível em:

<http://www.sbmac.org.br/bol/boletim_2002/assis-monim-souza-weidlich-4emc.pdf>. Acesso em: 17 jul. 2017.

BASSHUYSEN, R.; SCHAFER, F. Internal combustion engine handbook: basics, components, systems, and perspectives. SAE International, 2004.

BRUNETTI, F. Motores de combustão interna. Volumes 1 e 2 da 1.ed. São Paulo: Editora Blucher, 2012.

CIMM. Elementos químicos presentes e sua influência. Disponível em: $<$ http://www.cimm.com.br/portal/material_didatico/6362-elementos-quimicospresentes-e-sua-influencia\#.WWPVTxXytpg>. Acesso em: 10 jul. 2017.

COELHO, R. N. da C.; BELCHIOR, C. R. P. DIAGNÓSTICOS DE MOTORES DIESEL PELA MONITORAÇÃO DA COMBUSTÃO. XV Congresso Brasileiro de Engenharia Mecânica. São Paulo, 1999.

EPMA - EUROPEAN POWDER METALLURGY ASSOCIATION. Powder metallurgy in numbers. Disponível em: <http://www.epma.com/powder-metallurgy-economicadvantages $>$. Acesso em: 31 jan. 2017.

FRANÇOIS, M.; SPRAUEL, J. M.; DEHAN, C. F.; JAMES, M. R.; CONVERT, F.; LU, J.; LEBRUN, J. L.; LI, N.; HENDRICKS, R. W. X-Ray Difraction Method. In: Lu, J. Handbook of measurement of residual stresses. Society for Experimental Mechanics; Fairmont Press, Dec. 1996. cap. 5.

GEBAUER, K., Performance, tolerance and cost of TiAl passenger car valves. Intermetallics 14, p. 355-360, abr. 2006.

HEISLER, H. Advanced engine technology. SAE International, 1995.

HIGA, H. Y. Estudo e preposição para redução de consumo do motor flex-fuel. Monografia (Engenharia Mecânica) - Escola Politécnica, Universidade de São Paulo. São Paulo, 2011.

International Standard ISO 1585 Road vehicles - Engine test code - Net power. Third edition, 1992.

JOST, H. P. Tribology: origin and future. Wear, v. 136, n. 1, p. 1-17, Fev. 1990.

KRUGER, Gerg. Valve seat inserts. Technical Paper Series, 2001. 
LAKSHMINARAYANAN, P. A.; NAYAK, N. S. Critical Component Wear in Heavy Duty Engines. Wiley, 2011.

LIMA, N. B. Aplicações de difratômetria de raios $x$ em análises de materiais. Curso de Técnicas Avançadas de Difração de Raios x Aplicadas a Materiais Nucleares, IPEN, Notas de aula. 2007.

LOURENCO, A.A.M. Otimização de sistema de pós-tratamento de gases de escape do tipo catalisadores seletivos em motores diesel. Dissertação de Mestrado - Faculdade de Engenharia Mecânica, Universidade Estadual de Campinas, 2010.

MINITAB. O que é estatística de Anderson Darling? Disponível em: https://support.minitab.com/pt-br/minitab/18/help-and-how-to/statistics/basicstatistics/supporting-topics/normality/the-anderson-darling-statistic/. Acesso em: 10 jun. 2017.

MONTEIRO, W. A.; BUSO, S. J. Caracterização de Materiais por Métodos Físicos: Técnicas Experimentais e Aplicações Práticas. Apostila de curso de Pós Graduação, 2004.

NEWSAM, J.M.; JACOBSON, A.J.; MCCANDLISH, L.E.; POLIZZOTTI, R.S. J. The structures of the n-carbides $\mathrm{Ni}_{6} \mathrm{Mo}_{6} \mathrm{C}, \mathrm{C}_{6} \mathrm{Mo}_{6} \mathrm{C}$, and $\mathrm{C}_{6} \mathrm{Mo}_{6} \mathrm{C}_{2}$. Solid State Chemistry. V. 75, ano 2, p. 296-304, ago. 1988.

NITSKE, W. R.; WILSON, C. M. Rudolf diesel: pioneer of the age of power. University of Oklahoma Press, United States, 1985.

$\mathrm{OH}$, J., JUNG, S., KIM, Y et al. The Oxidation effect of the Exhaust valve set wear. Technical Paper 912507, SAE, Troy, Michigan, 1991.

RACOLTA, P. M. Nuclear Methods for Tribology. Pergamon. V. 46, n. 6/7, p. 663672, 1995.

RADI, P. A.; SANTOS, L. V.; BONETTI, L. F.; AIROLDI, V. J. T. Tribologia, conceitos e aplicações. In: ENCONTRO DE INICIAÇÃO CIENTÍFICA E PÓS-GRADUAÇÃO DO ITA, 13., São Paulo. Anais...São Paulo: ITA, 2007.

BRASIL. Conselho Nacional do Meio Ambiente. Resolução no 403, de 2008. Dispõe sobre a nova fase de exigência do Programa de Controle da Poluição do Ar por Veículos Automotores - PROCONVE para veículos pesados novos (Fase P-7) e dá outras providências. Disponível em: < http://www.mma.gov.br/port/conama/legiabre.cfm?codlegi=591>. Acesso em: 20 jul. 2017

RIGAKU. Residual stress data process program 2 (ver. 2.0) d/max-2000 instruction manual, Rigaku Corporation. 10를 ed. 2006.

ROBERTS, W.H. Tribology in nuclear power generation. Tribology International, v. 14, ano 1, p. 17-28, fev. 1981. 
ROSEMBERG, R. C. General friction considerations for engine design. SAE International, 1982.

SANTOS, I. P. dos. Processamento e caracterização de aços sinterizados para uso em insertos de assento de válvulas. Dissertação de Mestrado. Instituto de pesquisas Energéticas e Nucleares, USP, São Paulo, 2014.

SEIREG, A. A. Friction and Lubrication in Mechanical Design. Marcel Dekker, Inc. 1998.

SERVIÇO NACIONAL DE APRENDIZAGEM INDUSTRIAL. Mecânica: Metrologia básica. Em parceria com a Companhia Siderúrgica de Tubarão. Espírito Santo, 1996.

STACHOWIAK, G. W.; BATCHELOR, A. W. Engineering Tribology. ButterworthHeinemann, 2013.

WANG, Y.S.; NARASIMHAN, S.; LARSON, J.M. and SCHAEFER, S.K. Wear and Wear Mechanism Simulation of Heavy-Duty Engine Intake Valve and Seat Inserts. ASM International. Journal of Materials Engineering and Performance. V. 7, 1998.

WANG, Yushu. Introduction to Engine Valvetrains. SAE International. 2007. 


\section{APÊNDICE - Avaliação da deformação plástica nas sedes de válvula através de difração de raio $X$}

Conforme observado nas análises em MEV foi detectada deformação plástica na superfície das sedes de válvulas. Diante deste fato foi verificado, através do emprego da difração de raio $X$, a tensão residual superficial de uma sede de válvula sem remover do cabeçote, submetida ao ensaio de 2000 horas em dinamômetro. Além desta peça foi analisada outra sem uso, após usinagem e montagem no cabeçote, para comparar o nível de tensão residual superficial antes e após o ensaio. Vale salientar que ambas as peças passaram pelo mesmo processo de fabricação e montagem.

Nos materiais policristalinos (metal ou cerâmica) livres de tensão, o espaçamento interplanar "do" para uma determinada família de planos não varia com a orientação desses planos, conforme Figura 60. Se o material é submetido a uma tensão, durante a deformação elástica, o espaçamento interplanar varia de acordo com a orientação dos planos, relativa à direção da tensão. A distância interplanar aumentará para os planos perpendiculares à direção da tensão aplicada e diminuirá para os planos paralelos a essa tensão, devido ao efeito Poisson, conforme Figura 61. A tensão em um cristal pode ser definida pela variação do espaçamento interplanar d-do, medida pela posição dos picos de difração (lei de Bragg), conforme (FRANÇOIS et al., 1996).

$$
\varepsilon=\frac{d-d_{0}}{d_{0}}=\frac{\Delta d}{d_{0}}=\left(\theta-\theta_{0}\right) \operatorname{cotg} \theta_{0}=-\Delta \theta \operatorname{cotg} \theta_{0}
$$

Sendo $\theta$ é a posição do pico de difração para o espaçamento interplanar $d$ (material tensionado) e $\theta 0$ é a posição correspondente para $d_{0}$ (material livre de tensão). A rede cristalina (os planos cristalográficos) é utilizada como extensômetro que pode ser lido através de experimentos de difração. Como em qualquer método de extensometria a tensão pode ser calculada a partir da medição da deformação em várias direções juntamente com a constante elástica do material, conforme (FRANÇOIS et al., 1996). 
Figura 60 - O espaçamento interplanar $d_{0}$ é o mesmo para todas as famílias de planos, em qualquer direção, quando o material está livre de tensões.

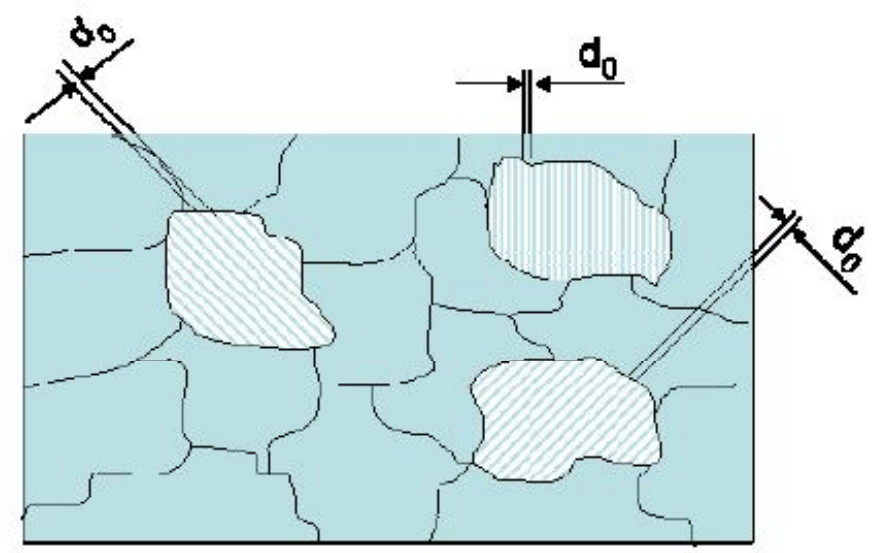

Fonte: FRANÇOIS et al., (1996).

Figura 61 - O espaçamento interplanar varia em todas as direções na presença de uma tensão.

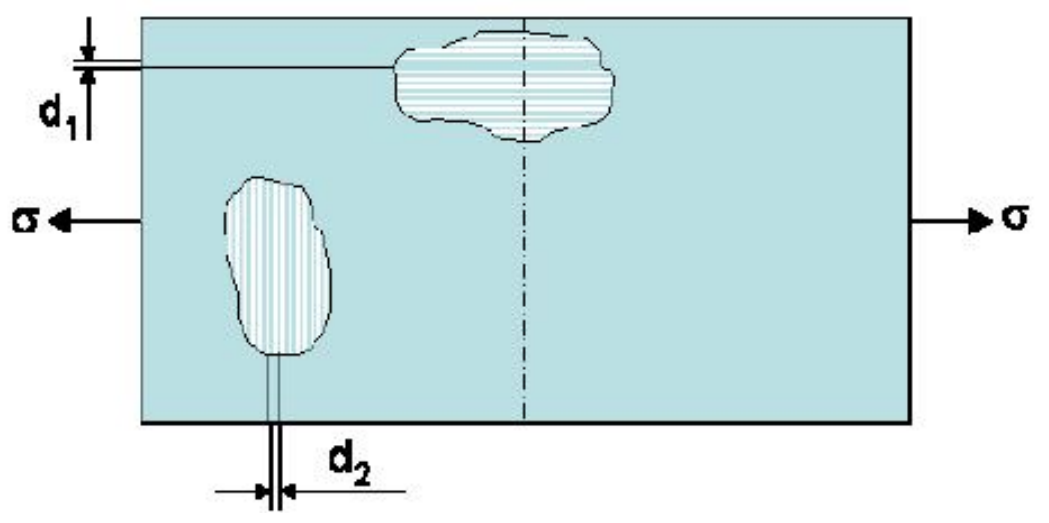

Fonte: FRANÇOIS et al., (1996).

Cálculos de tensão residual utilizando difratômetria de raios $X$ baseia-se na determinação de duas componentes de deformação $\varepsilon_{i} \psi 1$ e $\varepsilon_{i} \psi 2$ nas direções determinadas pelos ângulos $\phi$ e $\psi$ de um sistema de coordenadas esféricas, (ASSIS et al., 2008). Definindo a relação entre o plano da tensão e a distorção da superfície da amostra, pode-se calcular a relação da tensão para um dado grau de inclinação da superfície da amostra. A inclinação do plano de difração e o plano da amostra são definidos como $\psi$ (psi). Tomando um ponto qualquer na superfície da amostra como foco da medição, define-se $\sigma_{1}, \sigma_{2}$ e $\sigma_{3}$ como as tensões principais 
e $\varepsilon 1, \varepsilon 2$ e $\varepsilon$ з como as deformações principais. Devido ao plano de tensão, o valor de $\sigma 3$ para o eixo Z é 0, conforme Figura 62, (RIGAKU, 2006).

Figura 62 - Direções da tensão e deformação principais.

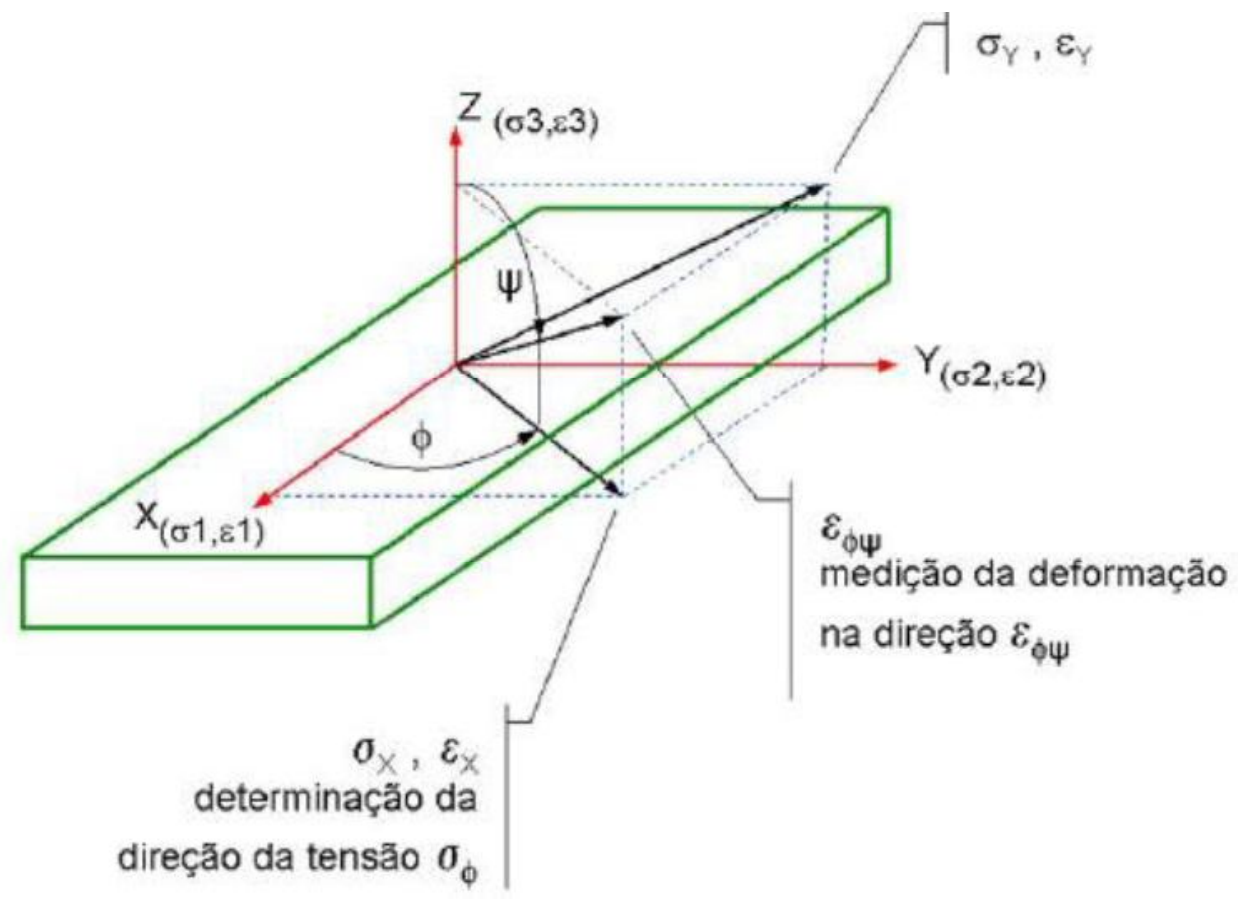

Fonte: (RIGAKU, 2006).

A deformação $\varepsilon_{i} \psi$ pode ser determinada através da equação (5) da teoria da elasticidade para o estado biaxial de tensões, (Assis at al, 2017):

$$
\varepsilon_{\phi \psi}=\left(\frac{1+v}{E}\right) \sigma_{\phi} \cdot \operatorname{sen}^{2} \psi-\frac{v}{E}\left(\sigma_{1}+\sigma_{2}\right)
$$

Neste caso a diferença entre as duas componentes da deformação será:

$$
\varepsilon_{\phi \psi 2}-\varepsilon_{\phi \psi 1}=\frac{1+v}{E} \sigma_{\phi}\left(\operatorname{sen}^{2} \psi_{2}-\operatorname{sen}^{2} \psi_{1}\right)
$$

Onde E (módulo de elasticidade) e $v$ (Poisson) são as constantes elásticas do material, $\psi$ e $\phi$ são os ângulos polares e azimutais, $\sigma_{\phi}$ a componente média da tensão, $\sigma_{1} \mathrm{e} \sigma_{2}$ as tensões principais. A componente $\sigma_{\phi}$ da equação (6) pode ser descrita como: 


$$
\sigma_{\phi}=\left(\frac{E}{1+v}\right) \frac{\varepsilon_{\phi \psi 2}-\varepsilon_{\phi \psi 1}}{\operatorname{sen}^{2} \psi_{2}-\operatorname{sen}^{2} \psi_{1}}
$$

Usando a lei de Bragg, a deformação $\mathcal{E}_{\Theta_{\psi}}$ pode ser determinada como:

$$
\varepsilon_{\phi \psi}=\frac{d_{\phi \psi}-d_{0}}{d_{0}}=-\operatorname{cotg} \theta_{0}\left(\theta_{\phi \psi}-\theta_{0}\right)
$$

Onde $d_{\phi} \psi, d_{0}$ e $\theta_{\phi} \psi, \theta 0$ são as distâncias interplanares e os ângulos de difração para materiais com e sem tensão respectivamente. A equação final para o cálculo da componente de tensão $\sigma$, na direção escolhida é:

$$
\sigma_{\phi}=\left(-\frac{E}{1+v}\right) \frac{\cot \theta_{0}\left(\theta_{\phi \psi 2}-\theta_{\phi \psi 1}\right)}{\operatorname{sen}^{2} \psi_{2}-\operatorname{sen}^{2} \psi_{1}} \frac{\pi}{180}
$$

Assim, para determinar qualquer componente de tensão é necessário medir os ângulos de difração correspondentes às reflexões dos planos cristalinos com normais caracterizadas por ângulos $\psi_{1}$ e $\psi_{2}$, (Assis et al, 2017). A equação (9) pode ser escrita em função de $\operatorname{sen}^{2} \Psi$.

$$
\phi_{\phi \psi}=\frac{180}{\pi} \frac{-\sigma_{\phi}}{\cot \theta_{0}}\left(\frac{1+v}{E}\right) \operatorname{sen}^{2} \psi+\theta_{\phi \psi_{0}}
$$

Para se obter resultados com maior precisão, é necessário que a medição do ângulo $\theta$ seja realizada em mais que duas posições $\psi\left(\psi_{1}, \psi_{2}, \psi_{3}, \psi_{n}\right)$. Os valores angulares de $\theta\left(\theta_{1}, \theta_{2}, \theta_{3}, \theta_{n}\right)$, correspondentes a cada ângulo $\psi_{n}$, são plotados em função de $\operatorname{sen}^{2} \psi$. O coeficiente angular de ajuste da função, $y=a x+b$.

Visto que, $E$, v e $\Theta$ são valores conhecidos, formam uma constante $(k)$ :

$$
\sigma_{\phi}=-k \frac{\delta(2 \theta)}{\delta\left(\operatorname{sen}^{2} \psi\right)}
$$


Na Figura 63, mostra-se o equipamento utilizado para medir a tensão superficial, Rigaku modelo Dmax 2010, seus respectivos componentes, o disposto utilizado para fixação do corpo de prova.

Figura 63 - Difratômetro utilizado para medição da tensão residual superficial (IPEN/CNEN$\mathrm{SP})$.
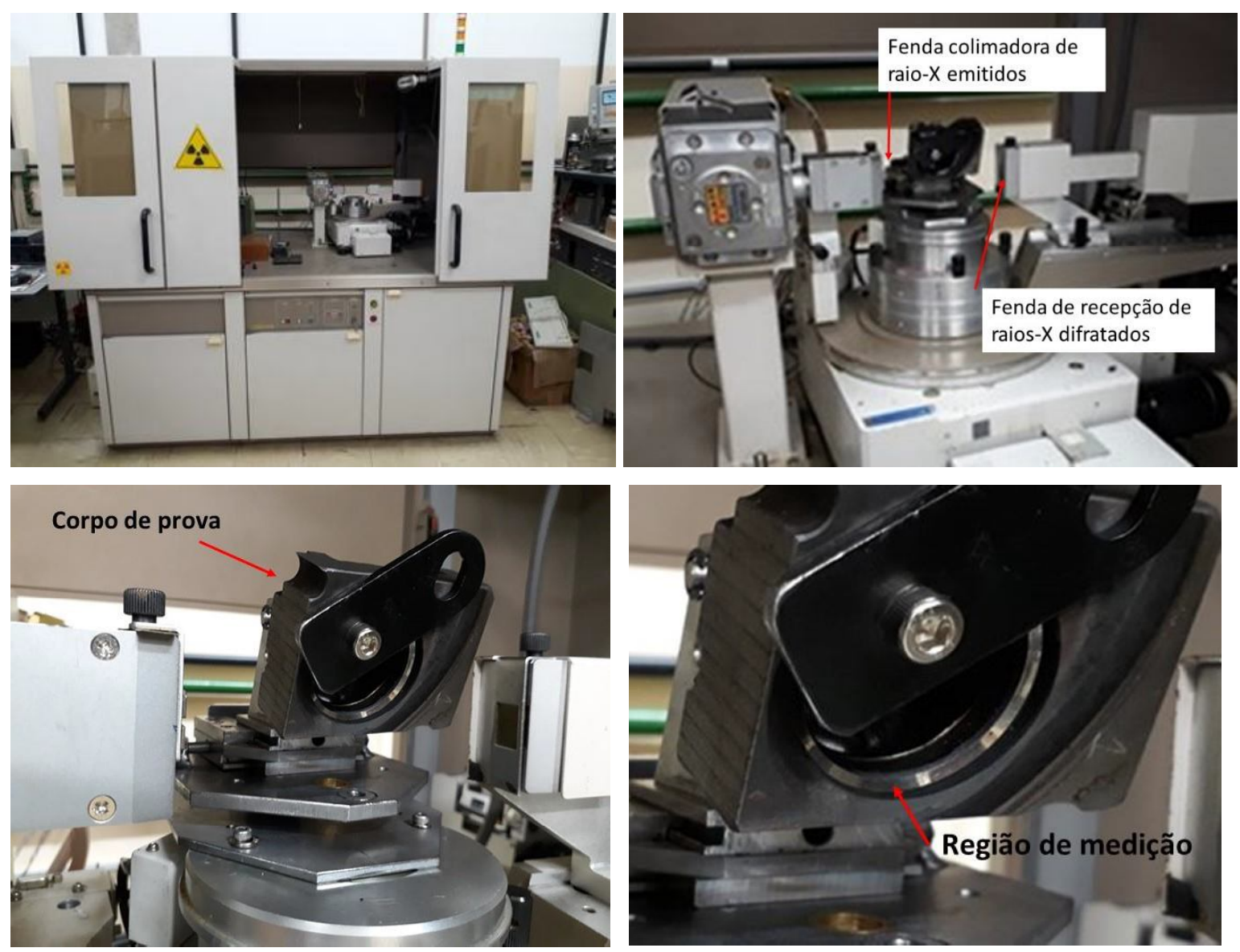

Fonte: autor da dissertação

Os resultados de tensão residual superficial da sede de válvula que realizou o ensaio de 2000 horas com a sede de válvula sem uso são demostrados na Figura 64, sendo que pode ser observado uma diminuição no valor de tensão residual na peça que realizou o ensaio. A sede de válvula submetida ao ensaio de dinamômetro apresenta tensão residual de $-527 \mathrm{MPa}$ e $-618 \mathrm{MPa}$ e a peça sem uso apresenta -864 MPa e -909 MPa de tensão residual superficial. 
Figura 64 - Tensão residual superficial da sede de válvula. Medição realizada por difração de raio $\mathrm{X}$ na região de contato com a válvula de admissão.

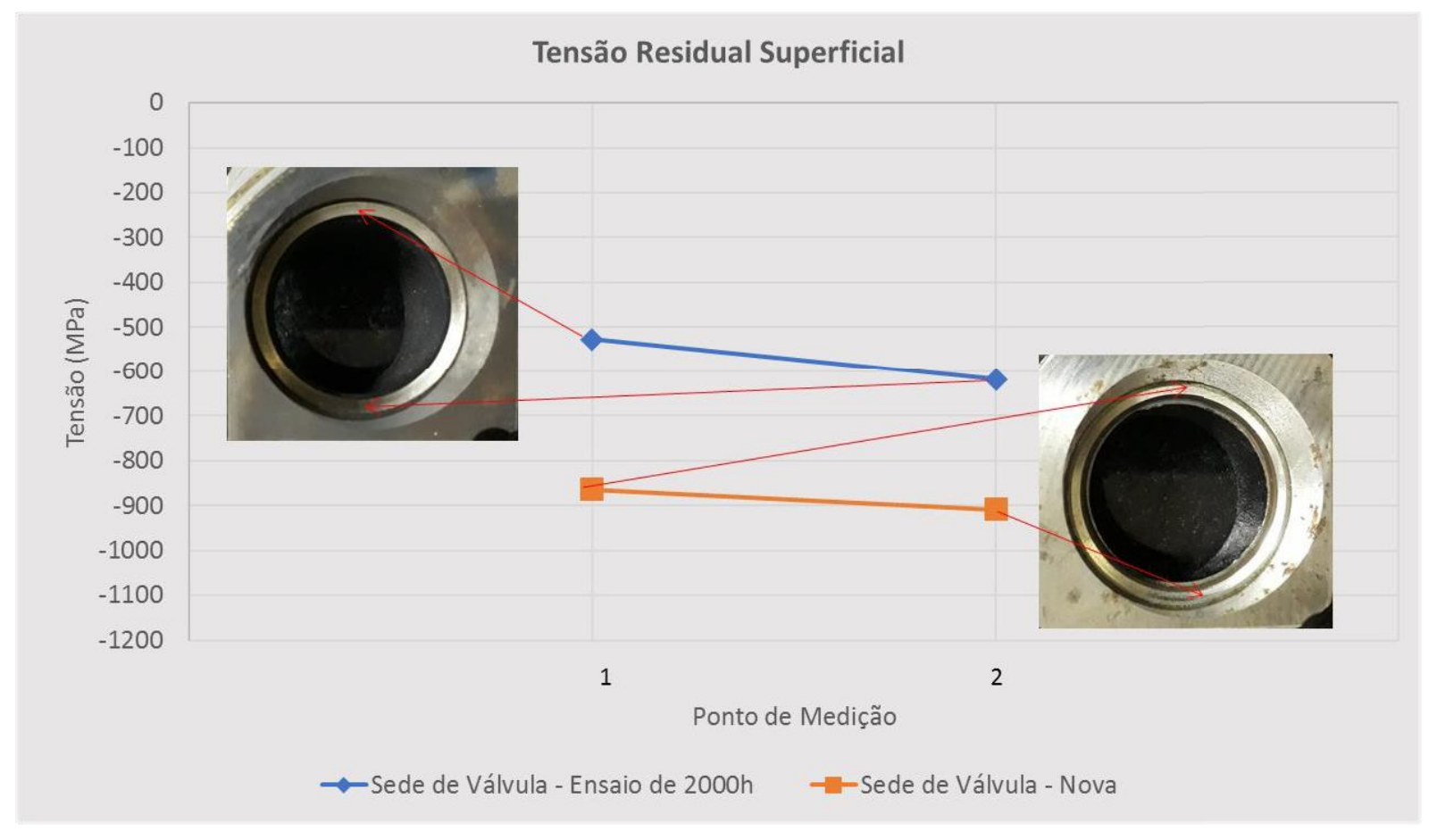

Fonte: autor da dissertação

Nota-se pelos resultados obtidos que houve uma diminuição nos valores de tensão residual superficial compressiva. Isso ocorreu, pois, a peça que realizou o ensaio de 2000 horas apresenta deformação plástica, conforme observado, por exemplo, na Figura 45, que devido ao cisalhamento da superfície alivia a tensão compressiva nesta região. Já a peça nova encontra-se mais tensionada e sem alteração da superfície. A temperatura não uniforme que ocorre na face de fogo do cabeçote também contribui para a redistribuição e modificação dos valores de tensões residuais superficiais nos componentes. Contudo ambas as peças apresentam tensão compressiva oriunda da deformação elástica da montagem por interferência da sede de válvula no cabeçote. 